Marcelo PaCheco Machado

\title{
DEMANDA E TUTELA JURISDICIONAL: ESTUDO SOBRE FORMA, CONTEÚDO E CONGRUÊNCIA
}

TESE DE DOUTORADO

ORIENTADOR:

Prof. Dr. José Roberto dos Santos Bedaque

FACULdAdE DE Direito dA

UNIVERSIDADE de SÃo PAUlo - FDUSP

SÃo Paulo, SETEMbro de 2013 


\section{AGRADECIMENTOS}

Agradeço a meu orientador, José Roberto dos Santos Bedaque, por ter fixado as premissas de trabalho e por ter me concedido oportunidades para o desenvolvimento da pesquisa que resultou nesta tese.

Agradeço os professores Heitor Vitor Mendonça Sica e Ricardo de Barros Leonel pelas preciosas críticas e contribuições feitas especialmente na fase de qualificação.

Deixo, ainda, agradecimentos aos colegas Bruno Vasconcelos Carrilho Lopes, João Francisco Naves Fonseca, Bruno Silveira de Oliveira, Fernando Fontoura da Silva Cais e Osly da Silva Ferreira Neto pela constante troca de ideias propiciada no curso do doutoramento.

Por fim, agradeço a minha família pelo apoio e, especialmente, a Michelle por tolerar tantas horas privadas do convívio familiar, necessárias para a conclusão desta tese. 


\section{INTRODUÇÃO}

A demanda é composta pela descrição de um litígio, um "problema" a ser solucionado pelo Judiciário, e por uma proposta de solução, elaborada pelo próprio demandante e que - normalmente - deve estar pautada no direito material.

O demandante, assim, pede duas coisas distintas, $\left(1^{\circ}\right)$ um ato de poder (meio) do Estado, que deve ter aptidão para desencadear uma determinada transformação da realidade (fim); e $\left(2^{\circ}\right)$ a própria transformação da realidade (bem da vida), com o cumprimento de uma prestação (tutela condenatória), fornecimento de uma certeza quanto a uma relação jurídica (tutela declaratória) ou criação, extinção ou modificação de uma relação jurídica (tutela constitutiva).

A tutela jurisdicional, por sua vez, é representada exatamente ou pela negativa ou pelo acatamento desta solução proposta. É concedida em favor do réu, quando a demanda é rejeitada (sentença terminativa) e o direito do réu é protegido pela Jurisdição (improcedência), e é concedida em favor do autor, quando a demanda é acolhida, permitindo que os efeitos jurídicos pleiteados sejam produzidos.

De modo que possamos estudar esta relação (demanda $v s$ tutela jurisdicional), em primeiro lugar precisamos definir o que é uma demanda e esclarecer do que esta demanda é feita.

Em segundo lugar, precisamos identifica-la, diferenciando-a de outros atos processuais similares.

Somente após a solução destas questões, poderemos tratar do modo pelo qual a demanda vincula e influencia a atividade jurisdicional, no que denominamos correlação ou congruência (sinônimos).

O Estado - via de regra - não pode exercer sua função jurisdicional, salvo se devidamente provocado por uma demanda (inércia), e uma vez demandado, antes de emitir qualquer ato de poder, deve submetê-la à apreciação dos demais indivíduos que podem vir a ser afetados (contraditório). Por força das exigências anteriormente citadas, o Estado acaba limitado pela solução proposta pelo demandante, não podendo ir além, aquém ou decidir o que não foi demandado (correlação). Fazê-lo significaria ofender a inércia e o contraditório, seria decidir a respeito de matéria que não foi objeto de provocação, a respeito da qual o demandado não teve oportunidade de reagir. 
O presente estudo se dirigirá aos diversos meios de formulação de demandas (iniciais e ulteriores) e a seus respectivos procedimentos, estabelecendo relação com o objeto litigioso do processo e com o conteúdo dos atos do Estado-juiz, aptos a conferirem a tutela jurisdicional. Mais do que isso, a tese busca tratar da identificação das demandas, em distinção a outros atos similares, e da interpretação e individualização do conteúdo da demanda e do objeto litigioso do processo, determinando seu espelhamento na sentença e na tutela jurisdicional.

Nosso objetivo é desenvolver critérios seguros para a solução destas questões que surgem nos foros a partir da conflituosa relação entre demanda e tutela jurisdicional (e não apenas entre demanda e sentença). Atendendo a esses propósitos, depois de assentados conceitos úteis, pretendemos nos dirigir, sempre que possível, à solução de problemas práticos. 


\section{SUMÁRIO}

I. INTRODUÇÃO

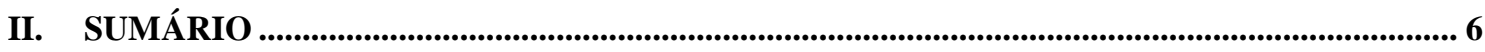

1. CONCEITO DE DEMANDA ......................................................................................................... 9

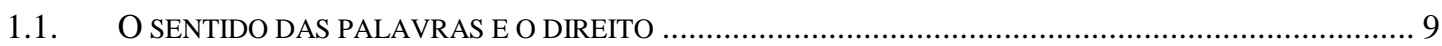

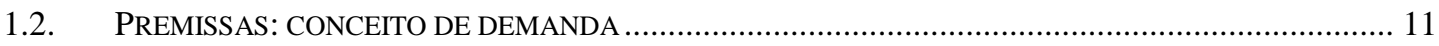

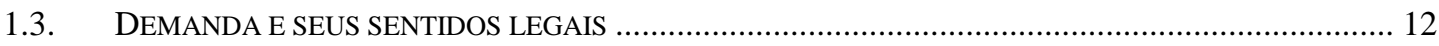

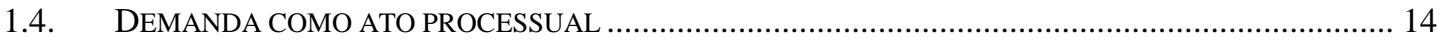

1.5. ATOS DE PARTE: CAUSATIVOS E INDUTIVOS ………........................................................ 18

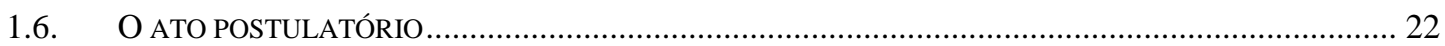

1.7. ATOS POSTULATÓRIOS ARGUMENTATIVOS E MEROS REQUERIMENTOS...................................... 23

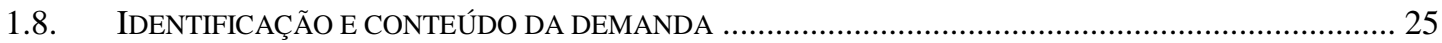

1.9. QUE SIGNIFICA INSTAURAR OU ALTERAR O OBJETO LITIGIOSO DO PROCESSO? ............................ 26

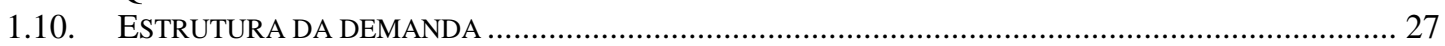

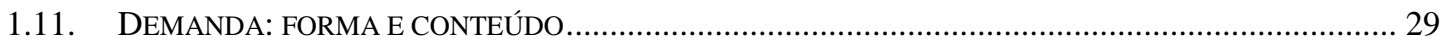

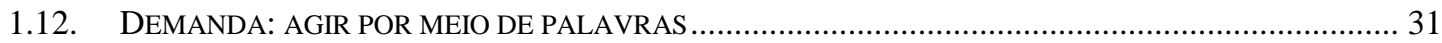

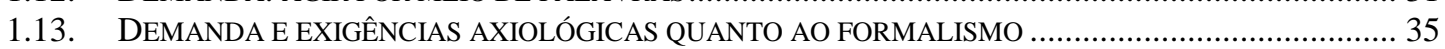

2. ESTUDOS SOBRE O CONTEÚDO DA DEMANDA ..................................................................... 39

2.1. OBJETO DO PROCESSO E OBJETO LITIGIOSO DO PROCESSO ……................................................. 39

2.2. CONTEÚDO DA DEMANDA E OBJETO LITIGIOSO DO PROCESSO …………................................... 41

2.3. TEORIA O OBJETO LITIGIOSO DO PROCESSO NA ALEMANHA E PRETENSÃO MATERIAL ................. 42

2.4. A PRETENSÃ̃ PROCESSUAL: AINDA SOBRE A PERSPECTIVA ALEM ̃̃ .......................................... 46

2.5. TEORIA DO TRIA EADEM: OUTRA PERSPECTIVA PARA O MESMO PROBLEMA ……….....................50 50

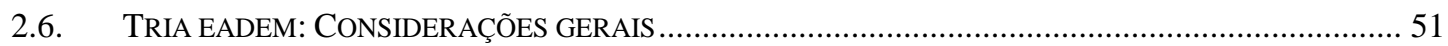

2.7. CAUSA DE PEDIR NA ITÁLIA: PENSAMENTO INICIAL ………………................................... 52

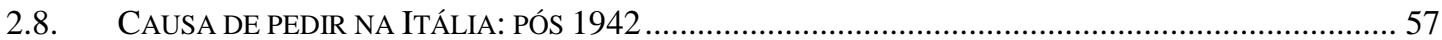

2.9. CRÍTICAS ÀS TEORIAS DA INDIVIDUALIZAÇÃO E SUBSTANCIAÇÃO ……………………………......... 59

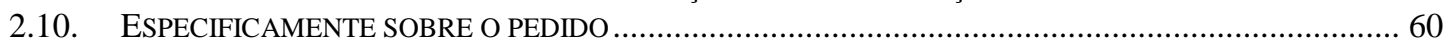

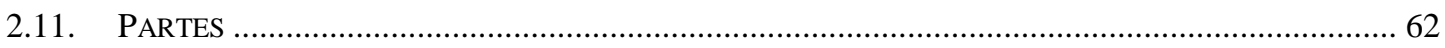

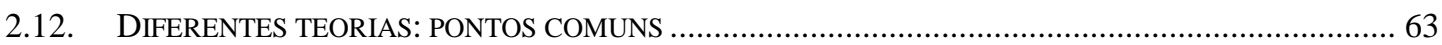

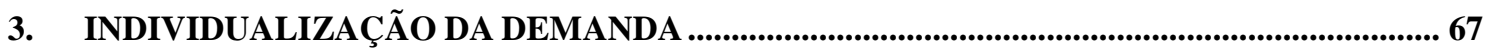

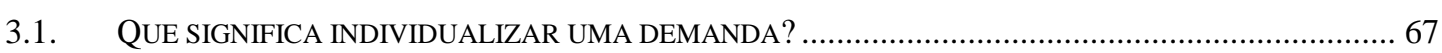

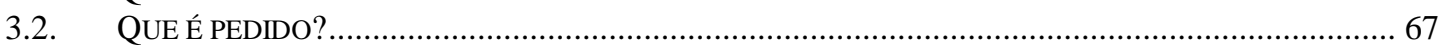

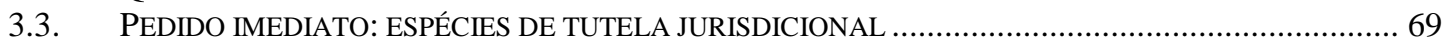

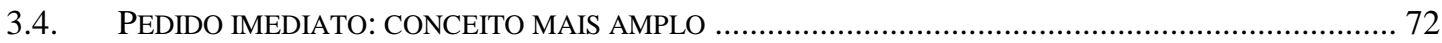

3.5. PEDIDO IMEDIATO, ESTABILIZAÇÃO DA DEMANDA E CORRELAÇÃO .......................................... 74

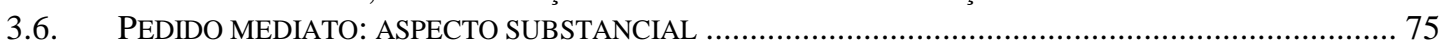

3.7. PEDIDO MEDIATO E BEM DA VIDA: DIFERENTES CRISES ........................................................ 77

3.8. NECESSIDADE DE VINCULAÇÃO DO CONTEÚDO DO PEDIDO À CAUSA DE PEDIR............................. 81

3.9. CAUSA DE PEDIR: ASPECTO FÁTICO E ASPECTO JURÍDICO ……............................................... 83

3.10. CAUSA DE PEDIR PRÓXIMA E INDIVIDUALIZAÇ̃̃o DA DEMANDA …………………..................... 87

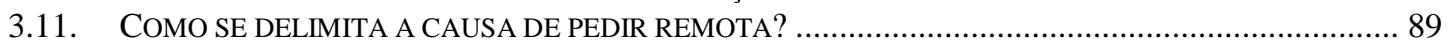

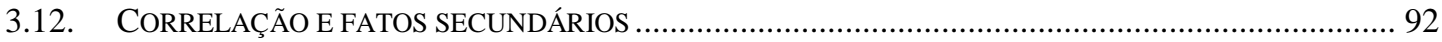

3.13. CAUSA DE PEDIR REMOTA: ENTRE SUBSTANCIAÇ̃̃O E INDIVIDUALIZAÇÃO …………………....... 94

3.14. INSUFICIÊNCIA DA NORMA DE DIREITO MATERIAL: AINDA IDENTIFICANDO O FATO ESSENCIAL. 99

3.15. IURA NOVIT CURIA E RELATIVIDADE DO FATO ESSENCIAL …………….................................. 102

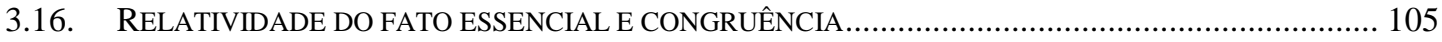

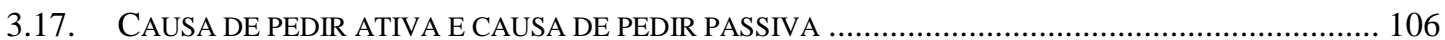

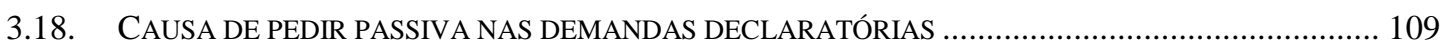

3.19. CAUSA DE PEDIR PASSIVA NAS DEMANDAS CONSTITUTIVAS .................................................. 111

3.20. CAUSA DE PEDIR PASSIVA NAS DEMANDAS CONDENATÓRIAS ..................................................... 113 
3.21. CAUSA DE PEDIR PASSIVA E INDIVIDUALIZAÇÃO DA DEMANDA......................................... 115

3.22. CONCEITO DE PARTE E SUA RELEVÂNCIA PARA A INDIVIDUALIZAÇÃO DA DEMANDA ............... 119

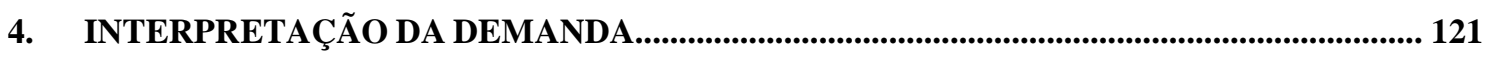

4.1. DEMANDA, LINGUAGEM E INTERPRETAÇÃO …….......................................................... 121

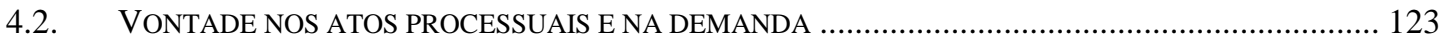

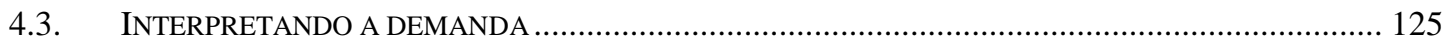

4.4. CONTRADITÓRIO COMO REFERÊNCIA À INTERPRETAÇÃO DA DEMANDA ……………………....... 127

4.5. INCERTEZA NA DEMANDA E INTERPRETAÇÃO RESTRITIVA ………………………………..... 130

4.6. INTERPRETAÇÃO RESTRITIVA É REGRA GERAL? …………..................................................... 133

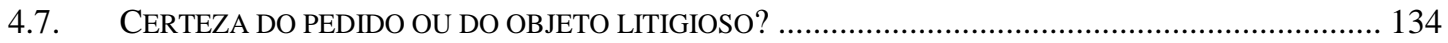

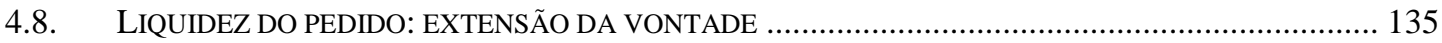

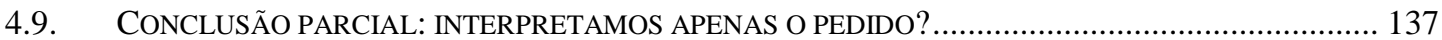

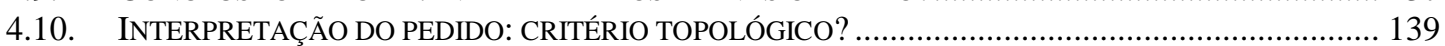

4.11. INCERTEZA E INTERPRETAÇÃO RESTRITIVA DO PEDIDO …….............................................. 141

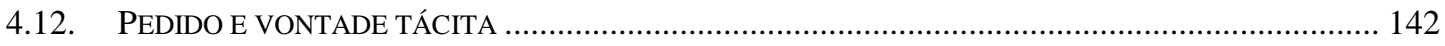

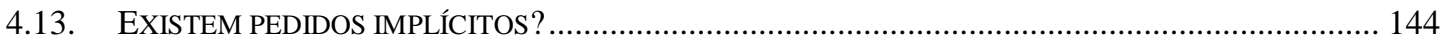

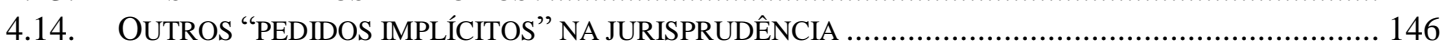

4.15. “EXCESSO DE CRIATIVIDADE” NA INTERPRETAÇÃO DO PEDIDO ………………........................ 149

4.16. QUANTIDADE E QUALIDADE DO PEDIDO: É POSSÍVEL ESTABELECER DISTINÇÕES CLARAS? ..... 153

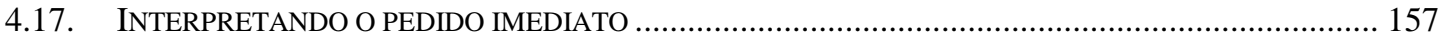

5. JUÍZO DE IDENTIFICAÇÃO DE DEMANDAS........................................................................ 160

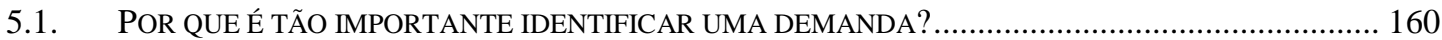

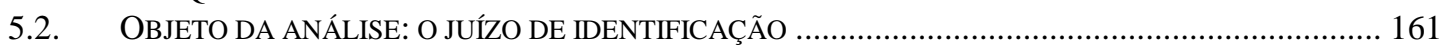

5.3. NOME E FORMA SÃO SUFICIENTES PARA IDENTIFICAR UMA DEMANDA? ................................... 164

5.4. NÃO É QUALQUER SORTE DE POSTULAÇÃO QUE IDENTIFICA UMA DEMANDA ……………….... 168

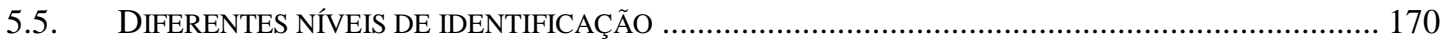

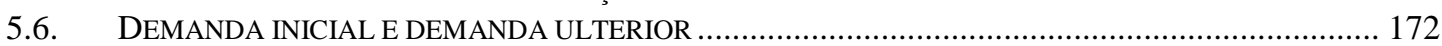

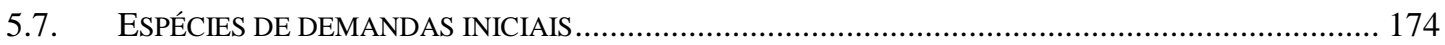

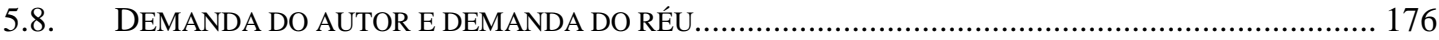

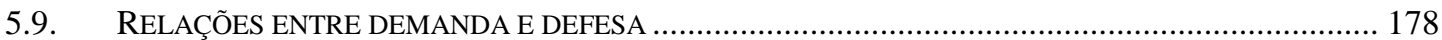

5.10. A DEFESA DO RÉU PODE SER INTERPRETADA COMO DEMANDA? ............................................... 180

5.11. O PROBLEMA DAS CHAMADAS EXCEÇÕES RECONVENCIONAIS .............................................. 186

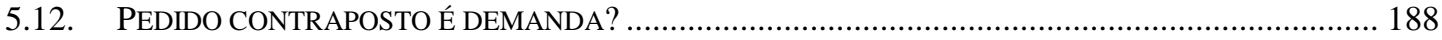

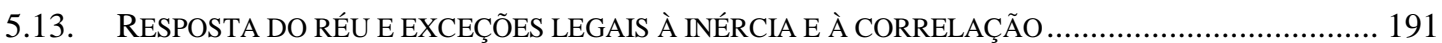

5.14. TUTELA DIFERENCIADA E EXCEÇÕES À INÉRCIA E CORRELAÇÃO............................................... 192

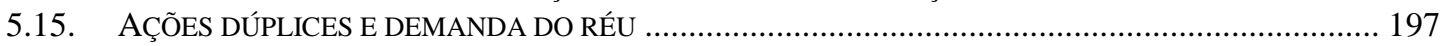

6. CONGRUÊNCIA: DEMANDA E TUTELA JURISDICIONAL ................................................. 203

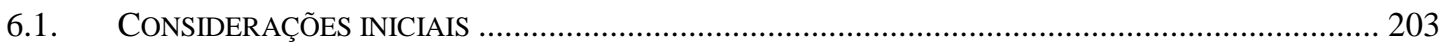

6.2. RELAÇÕES ENTRE DEMANDA, SENTENÇA E TUTELA JURISDICIONAL ............................................ 204

6.3. JUSTIFICATIVAS AXIOLÓGICAS DA CORRELAÇÃO ………......................................................... 205

6.4. CORRELAÇÃO E ESTABILIZAÇÃO DO OBJETO LITIGIOSO DO PROCESSO …………........................ 208

6.5. DEMANDAS ULTERIORES E ALTERAÇÃO DO OBJETO LITIGIOSO DO PROCESSO ……………….... 209

6.6. EXCEÇÕES LEGAIS À CONGRUÊNCIA …………………………………………………….... 210

6.7. ALTERAÇÃO LEGAL DO OBJETO LITIGIOSO: RESULTADO PRÁTICO EQUIVALENTE ...................... 212

6.8. RESULTADO PRÁTICO EQUIVALENTE: PEDIDO MEDIATO E PEDIDO IMEDIATO …........................ 214

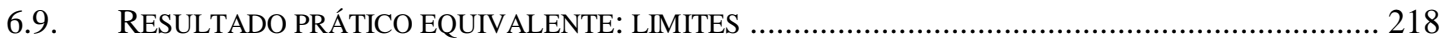

6.10. RESULTADO PRÁTICO EQUIVALENTE: APLICÁVEL À FASE COGNITIVA? ...................................... 223

6.11. OBRIGAÇÕES INFUNGÍVEIS E ART. 461 DO CPC.................................................................... 224

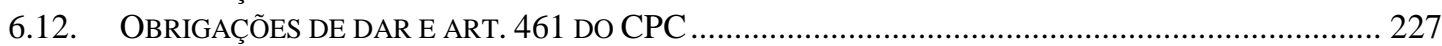

6.13. OBRIGAÇÕES DE PAGAR QUANTIA E ART. 461 DO CPC ......................................................... 228

6.14. RESULTADO PRÁTICO EQUIVALENTE: IMPOSSIBILIDADE E INADEQUAÇÃO DA MEDIDA.............. 229

6.15. MEIOS FORMAIS PARA A CONCESSÃO DO RESULTADO PRÁTICO EQUIVALENTE.......................... 231

6.16. INEXEQUIBILIDADE E CONVERSÃO EM PERDAS E DANOS: AINDA RELATIVIZANDO O OBJETO DO

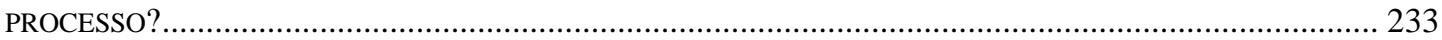




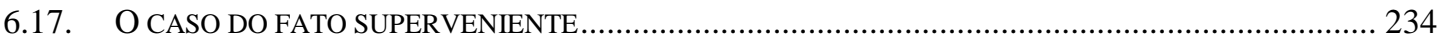

6.18. ALTERAÇÃO POR "FATOS SUPERVENIENTES”: LIMITAÇÕES .................................................. 237

6.19. ALTERAÇÕES ILEGAIS DO OBJETO DO PROCESSO: PROBLEMA DIFERENTE ............................... 239

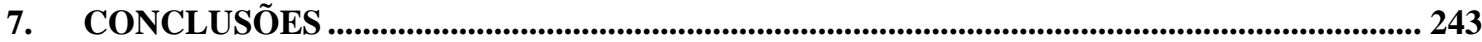

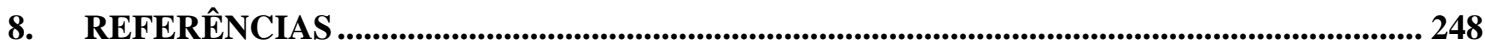




\section{CONCEITO DE DEMANDA}

\subsection{O SENTIDO DAS PALAVRAS E O DIREITO}

Como alertava Miguel Reale, as palavras nas ciências sociais ou humanas, se comparadas àquelas no domínio das ciências físicas ou naturais, estão muito mais intensamente submetidas à multiplicidade de significados. E há um motivo simples para isso: o uso corriqueiro, informal e reiterado acaba por transformar (multiplicar) o seu sentido. ${ }^{1}$

No âmbito do direito esta situação fica ainda mais clara, leis prescrevem “conceitos" e "termos" jurídicos, na sua linguagem técnica - muitas vezes imprecisa - e, nos foros, diferentes aplicadores vão lentamente atribuindo diferentes sentidos às expressões

Uma mesma palavra, assim, passa a ter diferentes significados em diferentes contextos ou, em muitos casos, num mesmo contexto jurídico, gerando graves problemas de comunicação, transvertidos em supostos debates a respeito da "natureza jurídica" das coisas.

Dois interlocutores falam de coisas distintas que têm o mesmo nome e acreditam poder - validamente - opor argumentos e vencer o debate; assim falsamente acreditam que travam debates doutrinários de alta profundidade. ${ }^{2}$

No âmbito do direito processual, a expressão "pedido", inobstante possuir bases históricas na evolução da dogmática e estar presente na linguagem técnica de diferentes ordenamentos jurídicos, serve de bom exemplo para esse fenômeno. Muito próxima aos foros e ao uso absolutamente aleatório, foi assumindo diferentes sentidos ao longo do tempo. Um dos mais citados o define como:

“o conteúdo da demanda, a pretensão processual, o objeto litigioso do processo, o mérito da causa"[...]"é o anseio, a aspiração do demandante, de que para aquela parcela da realidade social

\footnotetext{
${ }^{1}$ Cf. Filosofia do Direito, 1987, pp. 498-499.

${ }^{2}$ Cf. Tarék Moysés Moussallem, Fontes do direito tributário, $2^{\mathrm{a}}$ ed., pp. 29-30; e Osly da Silva Ferreira Neto, Ações tributárias coletivas, 2013, pp. 22-23.
} 
por ele trazida na demanda e que lhe está sendo prejudicial, seja dada a solução conforme ao direito segundo o seu modo de entender". ${ }^{3}$

Todos estes fenômenos, não podemos negar, relacionam-se de certo modo com a ideia de pedido que - de algum modo metafísico - acreditamos possuir arraigada em nossa mente e isso será investigado mais adiante. Mas tratariam de sinônimos? Seriam precisos o suficiente - do ponto de vista linguístico - para encerrar um conteúdo unívoco? E o que é pior, o seu acatamento seria suficiente para solucionar os problemas práticos que pairam a respeito da identificação do pedido no processo e de todas as consequências jurídicas daí decorrentes?

O mesmo problema se repete quando tratamos da demanda. Especialmente neste caso, o termo não foi amplamente encampado pelo nosso direito positivo, de modo que como veremos adiante - o Código se vale de termos como "ação" para designá-la (e.g. CPC, art. 28 e 37), e se vale dos termos "demanda" (e.g. CPC, art. 700, III), "demandado" (e.g. CPC, art. 12, $\left.\S 2^{\circ}\right)$ e "demandar" (e.g. CPC, art. 922) para se referir a situações muito distintas da acepção técnica do vocábulo.

Diante destes problemas, em primeiro lugar, buscaremos definir conceitos precisos a partir da interpretação sistemática do direito positivo. Não acreditamos na possibilidade de descobrir ou desvendar "o verdadeiro sentido" das expressões ou “institutos” jurídicos e, portanto, este, em momento nenhum, será nosso objetivo. ${ }^{4} \mathrm{Em}$ segundo lugar, também à luz do direito positivo, buscaremos desenvolver conceitos que tenham aptidão - quando efetivamente aplicados às regras jurídicas às quais se relacionam

\footnotetext{
${ }^{3}$ A definição retrata exatamente a ambiguidade de que sofre o termo e é um bom começo na tentativa de solucionar o complicado problema de delimitação de um conceito. Pela sua abrangência, acaba por retratar uma gama de questões - não muito bem resolvidos - a pairar sobre o que é (rectius o que deve ser) efetivamente "pedido" para o processo civil brasileiro. A definição resume diferentes posições, correlacionando o pedido com ação, demanda, mérito, técnica processual, objeto litigioso do processo, pretensão, relação de direito material, tutela jurisdicional (solução) e vontade da parte. Cf. Milton Paulo de Carvalho, O pedido no processo civil, 1992, p. 97.

${ }^{4}$ Os textos legais são constituídos a partir de linguagem técnica, passível de admitir diferentes sentidos, a partir da sua utilização. Há elementos históricos que determinam o sentido das palavras, mas estes podem facilmente serem corrompidos pelo uso e pela aplicação. O sentido de ação pode ser compreendido a partir do conceito romano de actio, a partir do sentido moderno da expressão na doutrina italiana ou mesmo a partir da linguagem do foro brasileiro. Nenhum desses sentidos coincidirá, correndo-se ainda o risco de se observar que, mesmo nos citados contextos, há variabilidade de sentidos para a mesma expressão, vide a polêmica sobre a actio que originou os debates de Windscheid e Muther. Por este motivo, acreditamos que não cabe ao jurista procurar saber a "essência das coisas" ou a "natureza jurídica" dos institutos, cabe-lhe descobrir o possível significado dos conceitos jurídicos, à luz dos critérios adequados de interpretação do direito positivo. A respeito da questão, Tarék Moysés Moussallem aponta que tal problema metodológico é fonte de inúmeros pseudoproblemas no estudo do direito, tais quais as discussões sobre a "natureza jurídica da contribuição social", sobre a "natureza jurídica da posse" (fato ou direito?), "natureza jurídica da letra de câmbio" e a "natureza jurídica do casamento". (Cf. Fontes do direito tributário, $2^{a}$ ed., pp. 29-30).
} 
- de produzir os resultados mais adequados aos escopos do processo (de acordo com os critérios hermenêuticos aplicáveis).

Este aspecto, especialmente, se dá, pois a relevância dos conceitos jurídicos muito longe de ser a busca da natureza jurídica ou da essência das coisas - é justificada pelo fato destes constituírem o antecedente normativo de diferentes normas jurídicas, i.e. estarem presentes na linguagem prescritiva do direito ("texto das leis"), de modo que a delimitação precisa de seu sentido acaba por influenciar o conteúdo da própria norma (fattispecie), da sua moldura normativa e do seu sentido deôntico. Assim veremos.

\subsection{PREMISSAS: CONCEITO DE DEMANDA}

A demanda é um ato singular para o processo civil, importando a instauração do mecanismo estatal de resolução de controvérsias e a delimitação de seu objeto litigioso, da matéria que será objeto da tutela jurisdicional, a ser potencialmente concedida por meio do processo. Para Dinamarco:

\footnotetext{
"o ato de vir ao juiz pedindo tutela jurisdicional" [...] "tem por conteúdo uma pretensão de quem o realiza". ${ }^{5}[. .$.$] "demanda é um ato e não se confunde com ação, que é um direito, ou poder. Não é$ correto dizer que se propõe uma ação, mas uma demanda: é esta que se considera proposta, ou seja, posta diante do juiz à espera de satisfação". ${ }^{6}$
}

Este ato se difere profundamente dos meros requerimentos, que não possuem conteúdo jurídico/fático relevante (argumentação), e também dos atos postulatórios de mera defesa, na medida em que em seu conteúdo não há manifestação da vontade da parte em alterar o objeto litigioso do processo.

Pela regra geral, o réu pode receber a mesma tutela jurisdicional (extinção do processo ou improcedência), ainda que não tenha oferecido defesa alguma, o autor, no entanto, pode apenas receber tutela jurisdicional (procedência) caso, antes, tenha formulado demanda. Do mesmo modo, a demanda se difere dos atos recursais, na medida em que estes não ampliam o objeto litigioso do processo, mas apenas prorrogam a litispendência e permitem a revisão de um julgado.

\footnotetext{
${ }^{5} \mathrm{Cf}$. Dinamarco, Instituições de direito processual civil, vol. II, p. 102.

${ }^{6}$ Dinamarco, Instituições de direito processual civil, vol. I, p. 301.
} 
Tudo isso, conforme demonstraremos, depende das escolhas feitas pelo direito positivo, que aloca determinados atos em determinadas categorias jurídicas, com "nomes distintos", decorrendo daí várias consequências jurídicas relevantes, tais quais a admissibilidade, o procedimento, os efeitos, etc.

Feitas estas considerações, e levando em conta os compromissos afirmados acima, chegamos ao seguinte conceito de demanda, que a seguir será mais bem definido: ato processual da parte, indutivo, postulatório, essencial e argumentativo, pelo qual se manifesta claramente a vontade de instituir ou alterar o objeto litigioso de um processo.

Em conformidade com o quadro abaixo, analisaremos a demanda e suas repercussões no modelo constitucional de processo para, posteriormente, estudarmos em qual sentido o termo é empregado pela ordem infraconstitucional, quais são suas características fundamentais e em qual classe de atos processuais a demanda se insere.

\begin{tabular}{|c|c|c|c|c|c|c|c|c|}
\hline \multicolumn{9}{|c|}{ DEMANDA } \\
\hline Fato Jurídico & Ato Jurídico & Processual & Parcial & Indutivo & Postulatório & Essencial & Argumentativo & $\begin{array}{l}\text { Fim } \\
\text { específico }\end{array}$ \\
\hline $\begin{array}{l}\text { Fato relevante } \\
\text { para o direito. } \\
\text { Apto a criar, } \\
\text { modificar ou } \\
\text { extinguir } \\
\text { situações } \\
\text { jurídicas. }\end{array}$ & $\begin{array}{l}\text { Fato jurídico } \\
\text { realizado a } \\
\text { partir da } \\
\text { manifestação } \\
\text { da vontade } \\
\text { humana (fato } \\
+\quad \text { vontade } \\
\text { manifestada). }\end{array}$ & $\begin{array}{l}\text { Ato jurídico } \\
\text { que tem como } \\
\text { objetivo } \\
\text { criação, } \\
\text { modificação ou } \\
\text { extinção de } \\
\text { uma situação } \\
\text { jurídica dentro } \\
\text { do processo. }\end{array}$ & $\begin{array}{l}\text { Realizado } \\
\text { por sujeito } \\
\text { parcial do } \\
\text { processo } \\
\text { (parte). }\end{array}$ & $\begin{array}{l}\text { Não tem } \\
\text { aptidão para } \\
\text { causar de per } \\
\text { se o resultado } \\
\text { proposto ou } \\
\text { desejado. }\end{array}$ & $\begin{array}{l}\text { Visa a } \\
\text { influenciar } \\
\text { psicológica- } \\
\text { mente o juiz } \\
\text { na emissão } \\
\text { de um futuro } \\
\text { ato } \\
\text { jurisdicional. }\end{array}$ & $\begin{array}{l}\text { Caso não } \\
\text { realizado, } \\
\text { torna } \\
\text { impossível } \\
\text { a produção } \\
\text { dos efeitos } \\
\text { desejados. }\end{array}$ & $\begin{array}{l}\text { Contém } \\
\text { conteúdo } \\
\text { cognitivo } \\
\text { relevante. } \\
\text { Diferencia-se } \\
\text { dos meros } \\
\text { requerimentos. }\end{array}$ & $\begin{array}{l}\text { Expressa } \\
\text { vontade de } \\
\text { instituir } \\
\text { (inicial) ou } \\
\text { alterar } \\
\text { (ulterior) o } \\
\text { objeto } \\
\text { litigioso de } \\
\text { um } \\
\text { processo. }\end{array}$ \\
\hline
\end{tabular}

\subsection{DEMANDA E SEUS SENTIDOS LEGAIS}

O termo "demanda" permaneceu por muito tempo "excluído da dignidade do uso da linguagem mais técnica e apurada do direito processual civil brasileiro". E o Código de Processo Civil de 1973 é retrato desse fenômeno, dado a multiplicidade de sentidos que concede à expressão; utiliza-a como sinônimo de $\left(1^{\circ}\right)$ litígio, de $\left(2^{\circ}\right)$ pleito ou solicitação, ou mesmo de $\left(3^{\circ}\right)$ causa, $\left(4^{\circ}\right)$ processo ou $\left(5^{\circ}\right)$ relação jurídica processual. Institutos que deveriam apresentar sentidos distintos. ${ }^{7}$

${ }^{7}$ Cf. Dinamarco, Instituições de direito processual civil, vol. II, pp. 103-104. 
O termo é inicialmente usado para designar conflito de interesses deduzido em juízo, tal como na redação do artigo 700, inciso III, ao falar do "prejuízo do que perder a demanda".

A mesma expressão é utilizada como sinônimo de processo (instrumento estatal de resolução de controvérsias), quando o Código se vale dos termos "custear a demanda" (CPC, art. 852, par. único) ou “demanda pendente" (CPC, art. 593, III, 835, e 1.016, § 2) ou "natureza da demanda" (CPC, art. 277, § 4º).

No particípio passado (“demandado"), o Código a emprega para designar (i) o sujeito que ocupa o polo passivo da relação jurídica processual, em face de quem o pedido foi formulado, como em sociedades demandadas (CPC, art. 12, $\S 2^{\circ}$ ), e em "demandado" (CPC, art. 94); ou mesmo (ii) o bem jurídico, material ou imaterial, que de algum modo se relacionada ao pedido, i.e. bem ou coisa demandada (CPC, art. 62, 69, II, 70, II e 286, I).

O artigo 460, por sua vez, vale-se da palavra "demandado" para designar fenômeno completamente distinto, qual seja, o conteúdo do pedido, esclarecendo sua necessária e lógica correlação à sentença: “É defeso ao juiz proferir sentença, a favor do autor, de natureza diversa da pedida, bem como condenar o réu em quantidade superior ou em objeto diverso do que lhe foi demandado".

Ademais, o uso do verbo no infinitivo "demandar" designa alguma providência solicitada pela parte ao Estado, tal como ocorre nas expressões "demandar em nome de outrem" (CPC, art. 315, parágrafo único), "demandar declaração" (CPC, art. 521), demandar proteção possessória (CPC, art. 922), “demandar restituição de terrenos" (CPC, art. 974) e demandar a inclusão no inventário (CPC, art. 1001).

A mesma expressão é também utilizada pelo art. 984 do Código, no plural, ao se referir à impossibilidade de conhecimento das chamadas questões que "demandarem alta indagação" no curso do procedimento especial de inventário e partilha. ${ }^{8}$

Os sentidos da expressão "demanda", embora em grande parte relacionados ao fenômeno processual, é dizer: (i) por qual meio se demanda, (ii) o que se demanda, ou (iii) quem demanda ou é demandado, não atendem a uma exigência mínima de precisão conceitual.

E as impropriedades não param por aí. Por não incluir de forma sistemática o termo "demanda" em seu vocabulário, o Código se vale do termo "ação" para designar, exatamente, o ato ou efeito de pleitear em face do Estado a concessão da tutela

${ }^{8} \mathrm{O}$ sentido utilizado não possui qualquer relação com a temática tratada, na medida em que demandar, aqui, significa apenas “exigir” investigação profunda, e não solicitar algo a alguém. 
jurisdicional (ideia mais próxima do conceito adotado acima), assim é que se refere a "propor ação", "intentar ação", "ação proposta", "fundamento da ação", "ações conexas", etc. (cf. CPC, arts. 28, 37, 90, 94, 100, II e III, 103, 104, 106, 215, § $1^{\circ}, 219, \S 1^{\circ}, 263,268$, $\mathrm{V}, 281,283,285,301, \S 1^{\text {o }}$ a $3^{\circ}, 315,319,326,332$ e outros). ${ }^{9}$

Estas observações demonstram que a linguagem técnica dos textos normativos como sói de ocorrer - não apresenta critérios adequados para a delimitação precisa do sentido das palavras que emprega, exigindo uma investigação mais apurada. Para este mister, pretendemos investigar os atos processuais mais a fundo, de modo que possamos identificar as características específicas da demanda que permitem identificá-la.

\subsection{DEMANDA COMO ATO PROCESSUAL}

O processo civil é constituído de fatos jurídicos, é dizer, eventos empíricos - que dependem ou não dependem da vontade humana - e cuja ocorrência se submete à hipótese legal (fattispecie ou antecedente normativo, ora chamado "P") de determinada norma jurídica.

$\mathrm{O}$ resultado da incidência dos fatos (ora chamados "S") previstos ao antecedente da norma deve ser a produção dos efeitos previstos pelo seu consequente (sanctio iuris ora chamado "C").

Assim é a estrutura lógica da norma jurídica, e da norma jurídica que trata do processo civil (regra): dado tal fato (antecedente normativo ou fattispecie) $\rightarrow$ deve ser tal consequência jurídica (consequente normativo). Assim Karl Larenz:

\footnotetext{
“uma proposição jurídica completa, segundo o seu sentido lógico, diz: sempre que a previsão $\mathrm{P}$ está realizada nua situação de facto concreta $S$, vale para $S$ a consequência jurídica $C$. A previsão $\mathrm{P}$, conformada em termos gerais, realiza-se numa determinada situação de facto quando $\mathrm{S}$, do ponto de vista lógico, é um caso de P. Para saber que consequência jurídica vigora para uma situação de facto - cuja procedência - e sempre dada - tenho, portanto, que examinar se esta situação de facto é de subordinar, como <<caso〉>, a uma determinada previsão legal. Se assim for, a consequência jurídica resulta de um silogismo que tem a seguinte forma: Se P realizada numa situação de facto, vigora essa situação de acto a consequência jurídica $\mathrm{C}$ (premissas maior).
}

\footnotetext{
${ }^{9}$ Essa é exatamente a linha da crítica de Dinamarco, confeccionada a respeito da redação do Código de Processo Civil. Cf. Instituições de direito processual civil, vol. II, $3^{\text {a }}$ ed., p. 105
} 
Esta determinada situação de facto $\mathrm{S}$ realiza $\mathrm{P}$, quer dizer, é um <<caso〉> de $\mathrm{P}$ (premissa maior).

Para S vigora C (conclusão)".

Os efeitos jurídicos previstos pela da norma são comumente denominados “consequentes normativos" (sanctio iuris), e se resumem na criação, extinção ou modificação de uma situação jurídica. ${ }^{10}$ Isto de uma forma geral para todos os atos jurídicos, reproduzindo-se a mesma noção, quando tratamos especificamente dos atos processuais.

A ideia de ato processual é correlata à própria ideia de processo; processus est actus. No seu aspecto externo, o processo se apresenta exatamente como uma série de atos realizados por seus sujeitos que se ligam, uns aos outros, por força de um "nexo de coordenação a um fim específico", que é a relação jurídica processual. Conforme observam Satta e Punzi, "o processo é sobretudo uma série de modificações, de passagens, de situações, que encontram em cada ato a sua causa ou a sua condição". ${ }^{11}$

A demanda - conforme demonstraremos - nada mais é do que um ato jurídico processual, que se insere na categoria dos atos postulatórios: entendidos estes como os formulados ao Estado com o objetivo de que seja produzido um provimento jurisdicional (ato de poder).

Explicamos.

Os fatos jurídicos (gênero) se dividem em fatos (em sentido estrito) e atos jurídicos. Todo evento fático - ação, omissão ou fato da natureza - que tenha repercussões para o direito é fato jurídico (gênero). ${ }^{12}$ Para Carnelutti, o que identifica a juridicidade de um fato é sua aptidão para modificar uma situação no seu aspecto jurídico: "tornando-se jurídica uma situação que não o era; tornando-se não jurídica uma situação que o era; e modificando-se a situação jurídica na sua juridicidade". ${ }^{13}$

Eventos que não dependem da vontade humana e que têm relevância para o direito, provocando a criação, modificação ou extinção de relações jurídicas, são fatos jurídicos em sentido estrito. A título de exemplo, podemos considerar que a morte (evento natural, normalmente não volitivo) gera a sucessão (CC, art. 1.784 - cria novos direitos) e

\footnotetext{
${ }^{10}$ A respeito da inserção dos atos processuais na categoria dos atos jurídicos, cf. Satta-Punzi, Diritto processuale civile, $13^{\mathrm{a}}$ ed., pp. 197-198.

${ }^{11}$ Cf. Satta-Punzi, Diritto processuale civile, $13^{\mathrm{a}}$ ed., p. 196.

${ }^{12}$ Cf. Tércio Sampaio, "Teoria da norma jurídica: um modelo pragmático", A norma jurídica, 1980, p. 16-17.

${ }^{13}$ Carnelutti distingue os atos que criam e extinguem situações jurídicas dos atos que tem a mera aptidão de modificá-la, chamando os primeiro de fatos jurídicos originários e os segundos de fatos jurídicos derivados. Teoria geral do direito, Trad. A. Rodrigues Queiró, 2006, p. 300.
} 
extingue a personalidade jurídica (CC, art. $6^{\circ}$ - extingue uma situação jurídica). Do mesmo modo, uma enchente ou catástrofe natural (que não depende da vontade humana) configura justa causa, nos termos da lei processual, e permite a relativização da preclusão temporal e a devolução de prazos preclusivos (CPC, art. 183, $\S \S 1^{\circ}$ e $\left.2^{\circ}\right) .^{14}$

Atos jurídicos (espécies), por sua vez, são fatos (gêneros) realizados a partir da manifestação da vontade humana (fato + vontade manifestada). E os atos processuais se enquadram nesta categoria de ato jurídico ${ }^{15}$ - evento empírico produzido pela vontade humana - ao qual o direito atribui a qualidade de criar, modificar ou extinguir novas situações jurídicas, sendo processuais, "dentro do processo".

São especificamente "processuais" aqueles atos cujos efeitos se dirigem ao seio de uma relação jurídica processual, criando, modificando ou extinguindo uma situação jurídica relevante para o processo. ${ }^{16}$ Tratam, como assevera Liebman, do elemento mínimo do procedimento, por meio do qual os sujeitos do processo exercem seus poderes ${ }^{17} \mathrm{e}$ cumprem seus deveres e ônus processuais. ${ }^{18}$

Os sujeitos do processo, ao participarem de qualquer modo do contraditório e ao exercerem poderes, ônus e deveres processuais, e.g. requerendo, pedindo, demandando, despachando, decidindo, expropriando, certificando, opinando, etc., realizam atos processuais. Sua ação ou omissão ${ }^{19}$ provoca mudanças na relação jurídica processual, criando outros poderes, ônus e deveres, por força da incidência de determinadas normas jurídicas.

Assim é que a citação, ato processual do Estado, gera ao réu o ônus de responder à demanda (CPC, art. 302 e 319) e a intimação da sentença, também ato processual do

\footnotetext{
${ }^{14}$ A este respeito cf. Marcelo Pacheco Machado, Incerteza e processo, 2013, p. 139 e ss.

${ }^{15}$ Cf. Luis Alberto Vieira, "Teoría general del acto jurídico y los presupuestos procesales", Estudios Jurídicos en Memoria de Eduardo J. Couture, p. 893.

16 É exatamente a manifestação da vontade humana que diferencia um fato de um ato processual. Nesse sentido, Couture conceitua fatos processuais como "aquellos acaecimientos de la vida que proyectan sus efectos sobre el proceso. Así, la perdida de la capacidad de una de las partes, la amnesia de un testigo, la destrucción involuntaria de una o más piezas del proceso escrito, son hechos jurídicos procesales. Cuando los hechos aparecen dominados por una voluntad jurídica idónea para crear, modificar o extinguir derechos procesales, se denominan actos procesales". (Fundamentos de derecho procesal civil..., $4^{\mathrm{a}}$ ed., p. 166).

${ }^{17}$ Proto Pisani define ato processual como aquele pelo qual os sujeitos processuais exercitam seus poderes (Lezioni di diritto processuale civile, $5^{\text {a }}$ ed., p. 214). No mesmo sentido, cf. Crisanto Mandrioli, Diritto Processuale Civile, $18^{\circ}$ ed., vol. I, p. 416. O "poder", nesse sentido, corresponde ao exercício de uma conduta que é ou permitida ou obrigatória.

${ }^{18} \mathrm{Cf}$. Liebman, Manuale di diritto processuale civile, $5^{\mathrm{a}}$ ed., pp. 211-212.

${ }_{19}$ Angel Fermín Garrote aponta que um ato processual pode consistir tanto numa ação quanto numa omissão, na medida em que o direito processual atribuiria consequências relevantes para essas duas espécies de conduta. Conclui, assim, que "más exacto sería decir, que el acto procesal es todo acontecimiento que de cualquier manera influye en la relación procesal". ("Los actos jurídicos procesales", Estudios de nulidades procesales..., p. 35).
} 
Estado, gera ao sucumbente o ônus de recorrer (CPC, 506, II e 515). Ainda a título exemplificativo, a contumácia do sucumbente em recorrer (ato processual da parte, por omissão) gera ao vencedor o direito de executar a sentença definitivamente (CPC, 475-I, § $1^{\circ}$ ), a demanda (ato processual da parte) gera ao Estado o dever de prover a tutela jurisdicional (CF, art. $\left.5^{\circ}, \mathrm{XXXV}\right)$, entre outros.

$\mathrm{Na}$ essência, ato jurídico e ato processual são ações ou omissões de sujeitos de direito que geram consequências jurídicas relevantes, exatamente porque se submetem aos antecedentes de normas jurídicas abstratas (fattispecie), acarretando efeitos previstos pelos seus respectivos consequentes (sanctio iuris).

A peculiaridade que permite diferenciar atos processuais dos demais atos jurídicos está na destinação de sua eficácia. Um ato é processual quando seus efeitos se direcionam ao interior de determinada relação processual, e, nessa medida, tem o condão de criar, modificar ou extinguir situações jurídicas dentro do processo (instrumento estatal de resolução de controvérsias). ${ }^{20}$

${ }^{20}$ No direito processual, ao contrário do direito privado, a eficácia do ato realizado não depende da manifestação da vontade do agente. Os atos do processo têm eficácia vinculada por normas pré-estabelecidas, que especificam requisitos para a sua realização e estipulam, desde logo, todos os efeitos a serem produzidos no mundo jurídico.

A doutrina assevera a importância meramente secundária da vontade, no que tange à eficácia dos atos processuais. Cf. Satta-Punzi, Diritto processuale civile, $13^{\mathrm{a}}$ ed., p. 198; Liebman, Manuale di diritto processuale civile, $5^{\mathrm{a}}$ ed. p. 216; Crisanto Mandrioli, Diritto Processuale Civile..., 18 ${ }^{\mathrm{a}}$ ed, vol I, p. 418; Bedaque, Efetividade..., 2006, p. 413; e Marcelo Bonício, Capítulos de sentença..., p. 20. Para avaliarmos a eficácia de um ato processual basta, em princípio, analisarmos a compatibilidade entre a forma de sua realização e o modelo formal previsto na lei. Alvaro de Oliveira, ao definir forma em sentido estrito, adota posição metodológica criticável ao se utilizar da citada expressão para indicar duas coisas completamente distintas. Afirma o processualista que forma em sentido estrito seria tanto a exteriorização do ato quanto os requisitos legais previstos para a sua validade. Vejamos suas palavras: "a forma em sentido estrito é o invólucro do ato processual, a maneira como deve se exteriorizar; cuida-se portanto do conjunto de signos pelos quais a vontade se manifesta e dos requisitos a serem observados na sua celebração". (Do formalismo no processo civil, $2^{\mathrm{a}}$ ed., p. 5).

Liebman esclarece que, exatamente pela circunstância de não produzirem os narrados efeitos jurídicos para o processo, "não são havidas como atos processuais as simples atividades de fato dos sujeitos do processo, de finalidade preparatória, tais como o estudo dos autos pelo juiz, as instruções das partes aos seus defensores, etc". Acrescenta ainda que "nem são atos processais aqueles realizados pelas partes fora do processo, embora possam ser destinados a este e sobre este produzir algum efeito", citando como exemplo "a eleição de domicílio por uma das partes, a outorga da procuração ad judicia ao defensor, a celebração de uma transação entre as partes, ou de um compromisso arbitral, e assim por diante". Para o processualista, ato processual é "uma declaração, ou manifestação de pensamento, feita voluntariamente por um dos sujeitos do processo, enquadrada em uma das categorias de atos previstos pela lei processual e pertencente a um procedimento, com eficácia constitutiva, modificativa ou extintiva sobre a correspondente relação processual”. (Manual de direito processual civil, trad. Cândido Rangel Dinamarco, item 98).

Em sentido contrário, Satta-Punzi sustentam que os atos processuais devem ser definidos como tal levando-se em consideração a norma que os regulam. Afirmam que a tentativa de definir o ato processual com base em seus efeitos não seria bem sucedida, tendo em vista que a juridicidade do ponto de vista de seu efeito é expressa a partir de sua coordenação com o exercício da jurisdição, todavia, este efeito não seria processual, mas simplesmente jurídico. Os autores assim citam a sentença, que seria um ato processual, mas cujos efeitos seriam produzidos especialmente sobre a relação de direito material, regulando-a concretamente. Acrescenta que existiriam atos não processuais que regulariam o processo, tais quais a eleição 
A demanda, como demonstraremos, é um ato processual, na medida em que apresenta todas as citadas características; é um ato de um sujeito processual (demandante, autor, réu ou terceiro, etc.), pelo qual este manifesta expressamente sua vontade por meio de uma argumentação, que se submete a diferentes modelos da lei processual (inicial, reconvenção, oposição, denunciação da lide, "pedido contraposto", etc.) e que tem a propensão geral de produzir um efeito específico: instituir ou alterar o objeto litigioso do processo.

\subsection{ATOS DE PARTE: CAUSATIVOS E INDUTIVOS}

Dentro da multiplicidade de atos processuais, diferentes critérios de classificação são admitidos. Admitiremos inicialmente dois: (i) classificação quanto ao sujeito (atos da parte e atos do Estado-juiz) e quanto (ii) à sua finalidade (atos indutivos e causativos ou de causação), sendo certo que o segundo critério é subcategoria do primeiro e diz respeito, especificamente, aos atos da parte, objeto de estudo do presente trabalho. ${ }^{21}$

A primeira categoria, de mais simples compreensão, remete-nos ao agente competente; quando ato realizado por sujeito parcial do processo (demandante ou demandado), tratamos de ato de parte, ${ }^{22}$ quando realizado pelo juiz ou seus auxiliares, sem interesse privado na causa, tratamos de ato do Estado-juiz (ato imparcial).

de foro, o compromisso de foro, a renúncia à competência e a aquiescência à sentença (Cf. Diritto processuale civile, $13^{\mathrm{a}}$ ed., p. 198).

21 Jaime Guasp justifica a necessidade de classificação, sob o argumento de que: "La extraordinaria pluralidad de actos que reciben el cálificatativo de procesales, la distinta naturaleza que cada uno o cada grupo de ellos há de sñalarse y su constante aparición en el proceso, obliga a intentar, para dar aunque no sea más que una idea elemental de problema, su clasificación". O autor, após mencionar os diferentes critérios para a classificação dos atos processuais, propõe a utilização do critério da "função" dos atos processuais, distinguindo-os em "atos de iniciação processual", aos quais inclui a demanda e os recursos, e "atos de desenvolvimento", divididos nas subcategorias "atos de instrução processual", "atos de ordenação", "atos de impulso", "atos de direção", "atos de constância" e "atos de terminação". (Cf. Derecho procesal civil, 1961, pp. 273-278).

${ }^{22}$ Liebman, levando em consideração os efeitos, divide os atos de parte em duas categorias distintas, atos causativos e atos indutivos: "Com relação a seus efeitos, os atos processuais de parte podem distinguir-se em causativos e indutivos. Os primeiros operam seu efeito na situação processual de imediato e por si próprios; já os segundos são destinados a obter do juiz um provimento favorável e, pois, a influir sobre sua convicção a respeito da procedência das razões da parte que realiza o ato. São atos da primeira categoria, p. ex., a constituição da parte no processo, a desistência da ação, a transação processual e, em geral, todos os que não pertencem à segunda categoria. Atos indutivos são os pedidos, as afirmações e a proposição e produção de provas (exceto das provas legais, que, justamente em razão da natureza destas, são atos causativos)". Manual de direito processual civil, 3. ed., Trad. Cândido Rangel Dinamarco, p. 324, v. I. No mesmo sentido, cf. Dinamarco, Instituições de direito processual civil, vol. II, p. 485. 
Todo ato processual pressupõe um agente especificamente competente para a sua realização, variando os requisitos e as finalidades dos atos como consequência da posição que cada sujeito adota no processo; i.e. exercício de uma função-dever jurisdicional (sujeito imparcial) ou pretensão de tutela de um interesse próprio (sujeito parcial).

O Estado-juiz, por meio de seus agentes (juiz e auxiliares), realiza no processo a "declaração de vontade" do Estado, por meio de pronunciamentos judiciais (sentenças, decisões e despachos) e atos chamados "materiais", que variam em função e em conteúdo e visam a declarar o direito material, dirimir questões processuais (atos decisórios), ordenar o andamento do feito (escrivão), contribuir para a prova (peritos e intérpretes) e viabilizar a concretização do direito ao caso concreto, mediante sub-rogação e coerção (execução em sentido estrito e lato).

Quanto às partes, são admissíveis diferentes subclassificações, a depender de o ato representar uma declaração de vontade (atos postulatórios) ou não (atos materiais), conforme veremos a seguir, da essencialidade (indispensáveis) ou não (convenientes), ou mesmo de seus efeitos, em criarem, modificarem ou extinguirem situações jurídicas (atos constitutivos, modificativos ou extintivos). ${ }^{23}$

Os atos de demandar, contestar e recorrer representam a vontade da parte e são atos postulatórios, outros atos como o depoimento pessoal são atos materiais que servem à instrução e não têm por finalidade obter um provimento jurisdicional, sendo realizados individualmente pela própria parte (sem a intermediação de advogado).

Há atos no processo, como a demanda, cuja não realização impede a gênese ou o desenvolvimento do processo (atos essenciais), outros, por sua vez, podem ser realizados de ofício, tal como a citação (CPC, art. 282, VII), de modo que a manifestação da parte é facultativa (não essencial), embora possa ser relevante (conveniente).

Por fim, há atos de parte que se diferem pela natureza de seus efeitos, como a demanda que inaugura a litispendência (ato constitutivo), a reconvenção, que altera/amplia o objeto litigioso do processo (ato modificativo) e a desistência recursal, que extingue a instância (atos extintivos). Conforme leciona Dinamarco, esta primeira classificação (entre

\footnotetext{
${ }^{23}$ Assim leciona Dinamarco: "Em resumo, os atos de parte serão: a) quanto ao conteúdo ou modo de proceder, postulatórios ou materiais; b) quanto à natureza do provimento postulado ao juiz, pedidos ou requerimentos; c) quanto à natureza dos efeitos visados, constitutivos, modificativos ou extintivos; d) quanto às consequiências de sua omissão, indispensáveis ou convenientes; e) quanto à autoria material, atos pessoais ou de advogado; f) quanto à participação dos litigantes em sua realização, unilaterais ou consensuais. Essa última classificação constitui conseqüência de uma outra: g) quanto ao modo como incidirão nas situações jurídico-processuais dos litigantes, os atos processuais de partes serão causativos ou indutivos (infra, n. 648). As condutas omissivas das partes não são atos jurídicos: projetam efeitos sobre o processo, na condição de fatos jurídicos processuais (supra, n. 639)". (Instituições de direito processual civil, vol. II, p. 487).
} 
atos do juiz e atos da parte) seria de "razoável utilidade", na medida em que permitiria "isolar de modo racional as muitas categorias de atos que no processo se realizam e põe em destaque a natureza de cada classe de atos e os fundamentos da possibilidade de realizálos". ${ }^{24}$ Especialmente, é importante na medida em que permite a adequada alocação dos atos processuais em suas categorias jurídicas, na medida em que cada um possui tratamento distinto pelo ordenamento jurídico.

A diferença entre atos causativos e indutivos, por sua vez, exige análise um pouco mais acurada. Definir atos com base em seu objetivo exige o conhecimento da razão de ser do ato processual, na medida em que há os que, pela sua natureza, têm objetivo de constituir imediatamente situação jurídica dentro do processo (atos causativos), ${ }^{25}$ bem como os que visam a propiciar a emissão de um futuro ato de poder do Estado "mediante influxos psíquicos emitidos sobre o juiz" (atos indutivos). ${ }^{26}$ Assim afirma Liebman:

\footnotetext{
"os primeiros [causativos] imediatamente e por si mesmos são operativos de seu efeito sobre a relação de direito material; os segundos [indutivos] por sua vez são direcionados a obter do juiz um provimento favorável e, portanto, a influir sobre sua convicção entorno da procedência das razões da parte que realiza o ato". ${ }^{27}$
}

É inegável que, especialmente os atos postulatórios (atos indutivos por excelência), têm como consequência, é dizer, são "causa imediata" da constituição, desconstituição ou modificação de uma situação jurídica, na medida em que sua ocorrência - submetendo-se ao antecedente de diferentes normas jurídicas - acarreta efeitos relevantes para o processo, que podem variar entre o surgimento do próprio processo pelo ato de demandar (constituição) ou mesmo o nascimento do ônus de produzir provas (impugnação específica na contestação - CPC, art. 302) e do dever de reexaminar o julgado (efeito devolutivo da apelação - CPC, art. 515). Tudo isso uma consequência que poderia se dizer “causativa” de uma situação processual nova.

Ocorre que tais atos apenas constituem ou causam novas situações processuais em caráter instrumental (objeto-meio), na medida em que têm como objeto-fim a emissão de

\footnotetext{
${ }^{24}$ Dinamarco, Instituições de direito processual civil, vol. II, p. 483.

${ }^{25}$ Cf. Jaim Guasp, Derecho procesal civil, 1961, p. 274.

${ }^{26}$ Asssim o faz Goldschmidt: "los actos de obtención pueden definirse como aquellos actos de las partes que se encaminan a impetrar una resolución de contenido determinado mediante influjos psíquicos ejercidos sobre el juez", Teoría general del proceso, p. 102. No mesmo sentido, cf. Leo Rosenberg, Tratado de derecho procesal civil, p. 364-367, t. I; Eduardo J. Couture, Fundamentos del derecho procesal civil, 4. ed., p. 169-170; J. Ramiro Podetti, Teoria y tecnica del proceso civil, p. 225.

${ }^{27}$ Liebman, Manuale di diritto processuale civile, t.1, 1992, pp. 241-242 (trad. livre).
} 
um ato de poder do Estado (provimento jurisdicional) que repercuta em proteção para a sua situação jurídica (tutela jurisdicional). É isto que fundamentalmente se quer quando o ato é formulado, e.g. uma decisão judicial, um despacho ou uma expropriação com determinado conteúdo.

Os atos indutivos, desse modo, a despeito de também produzirem efeitos de criação, modificação ou extinção, identificam-se por possuírem um objetivo adicional (precípuo), de influenciarem na emissão de um provimento futuro a respeito de suas pretensões, e não configurarem como fins em si mesmos. Estes provimentos do Estadojuiz, da forma como desejada pelo agente, não serão causa, consequência imediata do ato, que não lhe é condição única, mas são úteis (e.g. contestação) ou necessários (e.g. demanda) à sua emissão, e apresentarão elementos de convencimento para tanto.

Os atos indutivos - no que diz respeito especificamente à finalidade manifestada pelo agente - não causam de per se o resultado proposto (tutela jurisdicional). Assim como a demanda não gera por si só a tutela de procedência ou a contestação a de improcedência ou extinção processual. Assim Dinamarco:

\footnotetext{
"o ato de propô-la [demanda] não é suficiente para dar ao demandante o direito a esta [tutela], mas sem que a proponha jamais receberá tutela alguma". Do mesmo modo, "oferecer a contestação, com fundamentos que rebatem os do autor e com o pedido de sentença favorável, não significa que necessariamente o réu vá obtê-la - mas sem contestar ele torna-se revel, expondo-se ao efeito da revelia (presunção de veracidade das alegações de fato feitas pelo autor, art. 319 CPC) e ao grave risco de sair vencido na causa". ${ }^{28}$
}

Os atos causativos, diferentemente, são fins em si mesmos, e produzem por si só todos os efeitos desejados; geram imediatamente os efeitos pretendidos pelo agente. É dizer, não servem de preparação ou sequer influenciam psicologicamente o juiz na emissão de um ato ulterior. São atos aos quais o direito concede (especialmente por força do princípio dispositivo) a eficácia de produzirem, sem a necessidade de confirmação posterior, os efeitos substanciais desejados.

Esta eficácia imediata é concedida apenas em casos excepcionais às partes e tem como fundamento a disponibilidade do direito, tal como determina o artigo 158 do Código de Processo Civil: "Os atos das partes, consistentes em declarações unilaterais ou bilaterais de vontade, produzem imediatamente a constituição, a modificação ou a extinção de direitos processuais".

\footnotetext{
${ }^{28}$ Dinamarco, Instituições de direito processual civil, vol. II, p. 486.
} 
Apenas os atos dispositivos, tais quais a suspensão convencional do processo, prevista pelo artigo 265, II, do CPC, a desistência da demanda (antes da citação) e do recurso e a renúncia ao direito de recorrer, previstos pelos artigos 501 e 502 do CPC, admitem tal eficácia imediata. É dizer, tal efeito causativo é permitido apenas quando as consequências a serem produzidas afetam imediatamente o próprio agente, daí o poder conferido a este. Por isso, sabemos que atos causativos "são muito menos numerosos e menos frequentes na vida do processo, justamente porque a conduta ordinária de cada uma das partes consiste em buscar situações mais vantajosas, não em dispor delas". ${ }^{29}$

\subsection{O ATO POSTULATÓRIO}

Definido o conceito de ato processual e identificada a demanda como um ato processual indutivo, que já se adiantou tratar de ato postulatório, que visa a influenciar psicologicamente o juiz na emissão de um futuro ato jurisdicional, resta esclarecer no que consiste este último.

Postular significa pedir, pleitear alguma coisa. Juridicamente, o ato postulatório consolida o direito constitucional de petição, pelo qual o cidadão está autorizado a comparecer ante a autoridade, de modo a formular sua pretensão e obter uma resposta adequada. $^{30}$

No âmbito jurisdicional, o direito de petição nos remete à mais específica garantia de ação, de inafastabilidade e de acesso à justiça, que o ato de postular concretiza, é dizer, representa o exercício de tais garantias por diferentes jurisdicionados que pleiteiam um ato de poder do Estado apto a configurar melhoria/mudança na sua situação jurídica, pela plena tutela da relação de direito material ou por um benefício interno ao próprio processo. $^{31}$

Coube a Goldschimidt o mérito de originariamente identificar os atos postulatórios, os quais definiu com base em seu escopo de obter um pronunciamento

\footnotetext{
${ }^{29}$ Dinamarco, Instituições de direito processual civil, vol. II, p. 487.

${ }^{30} \mathrm{Cf}$. Eduardo Couture, "Las garantias constitucionales del proceso civil", Estudios de derecho procesal civil, $3^{\text {a }}$ ed., t.1, p. 28.

31 A lição é elementar, mas pela sua relevância deve ser reafirmada: "Demanda é um ato e não se confunde com ação, que é um direito, ou poder. Não é correto dizer que se propõe uma ação, mas uma demanda: é esta que se considera proposta, ou seja, posta diante do juiz à espera de satisfação" (Cf. Cândido Rangel Dinamarco, Instituições de direito processual civil, vol. I, p. 301).
} 
judicial de determinado conteúdo. Tal pronunciamento seria produto de influências psíquicas que o ato postulatório teria aptidão de produzir na mente do julgador. ${ }^{32}$

$\mathrm{Na}$ sua essência, o ato postulatório não é causa do provimento jurisdicional pleiteado (não é ato causativo), mas deve conter elementos argumentativos aptos a gerar o convencimento da atividade jurisdicional que, pautada nestes, haveria de ter condições de satisfazer uma pretensão do agente (ato indutivo).

Especialmente por influência de Liebman, ${ }^{33}$ que se aproxima do conceito de Goldschmidt, os atos postulatórios são definidos na doutrina brasileira a partir deste objetivo: obter um pronunciamento jurisdicional. ${ }^{34}$ É dizer, são atos processuais das partes, pelos quais estas manifestam sua vontade em obter provimento futuro que tenha aptidão de lhes gerar alguma vantagem, seja no âmbito do direito material, ou internamente ao próprio processo. $^{35}$

\subsection{ATOS POSTULATÓRIOS ARGUMENTATIVOS E MEROS REQUERIMENTOS}

Os atos postulatórios, por excelência, são as demandas e os recursos; as primeiras, normalmente, com o objetivo de obter pronunciamento judicial a respeito da aplicação do direito material ao caso concreto, instituindo ou alterando o objeto litigioso do processo (contendo pedido de tutela jurisdicional), os segundos com o objetivo de que seja emitido pronunciamento judicial apto a revisar outro pronunciamento, mantendo-o, reformando-o ou anulando-o, mas sem ampliar o objeto litigioso do processo ou instaurar nova relação jurídica processual.

São também atos postulatórios os atos de defesa, que contém requerimento de emissão de um ato judicial que traga situação jurídica favorável ao demandado, seja pela

${ }^{32}$ Cf. James Goldschmidt, Derecho procesal civil, 1936, p. 227; e Para Paula Costa e Silva, Acto e processo: o dogma da irrelevância da vontade na interpretação e nos vícios do acto postulativo, pp. 193196.

${ }^{33}$ Manual de direito processual civil, 3. ed., Trad. Cândido Rangel Dinamarco, p. 322, v. I.

${ }^{34}$ Cf. Grinover, Cintra e Dinamarco, Teoria geral do processo, $17^{\mathrm{a}}$ ed., p. 358.

${ }^{35}$ Nesse sentido, Bruno Silveira de Oliveira identifica dois elementos essenciais aos atos postulatórios (i) uma manifestação de vontade da parte; (ii) no sentido de obter certo provimento jurisdicional. $\mathrm{O}$ autor complementa que "A circunstância de a manifestação de vontade não observar, em concreto, as formalidades prescritas em lei não desnatura o ato como tal. Basta detectarmos a intenção da parte de obter um provimento judicial e nisso já haveremos identificado a existência de uma postulação (ainda que não consigamos, vez por outra, precisar em toda sua amplitude o alcance da vontade manifestada, dados os vícios de forma que a inquinam)". (O juízo de identificação de demandas..., 2011, p. 42). 
improcedência, pela extinção do processo sem julgamento de mérito (exceções peremptórias) ou pelo acolhimento de meras exceções dilatórias.

A contestação, bem como as defesas informais apresentadas no curso do processo (e.g. nulidade de citação, de prova pericial, de devolução de prazos, etc.), adequam-se ao conceito de ato postulatório: há a solicitação de um ato de poder estatal e a expectativa de que este seja produzido com determinado conteúdo. Ainda que este ato seja meramente instrumental e não configure, em si mesmo, tutela jurisdicional plena, apta a solucionar a crise de direito material.

A doutrina chega a arrolar como ato postulatório requerimentos de grande simplicidade, tais como a juntada de procuração ou substabelecimento aos autos. ${ }^{36}$ Do mesmo modo, poderíamos pensar que o requerimento de citação por edital, o requerimento de juntada extemporânea de documentos, entre outros, são também atos postulatórios, na medida em que veiculam solicitação de um provimento jurisdicional, ainda que se trate apenas de um ato aceitação ou conformidade tácita com o ato.

Nesta categoria de postulações, no entanto, há de se diferenciar os atos que pressupõem a apresentação de argumentos, aptos ao convencimento do juiz, porque exigem um exercício intelectivo de maior complexidade na incidência de fatos a normas, dos atos consideravelmente mais simples, que se limitam à apresentação de informações, requerendo a chancela do magistrado em ato posterior.

Os atos postulatórios argumentativos têm a função de persuadir racionalmente o órgão jurisdicional para que emita determinado pronunciamento, normalmente pelo motivo de existirem significativas questões de fato ou de direito que a serem dirimidas. Visam à obtenção de provimento jurisdicional caracterizado como decisão ou sentença, exatamente porque contém conteúdo cognitivo relevante. ${ }^{37}$

Os atos postulatórios não argumentativos, por sua vez, ocorrem por meio dos chamados requerimentos simples, que têm como objetivo a emissão de mero despacho. A despeito de também dependerem do juízo intelectivo do juiz, dependem em uma intensidade muito menor, tendo em vista a obviedade da aplicação do direito ao fato e.g.

\footnotetext{
${ }^{36}$ Cf. Bruno Silveira de Oliveira, O juízo de identificação de demandas..., 2011, p. 43.

37 A respeito da distinção entre despachos e decisões, pelo fato de apenas estas conterem "conteúdo decisório relevante", representado pela "atividade mental e intelectiva do juiz", cf. Flávio Cheim Jorge, Teoria geral dos recursos, $3^{\mathrm{a}}$ ed., pp. 49-50.
} 
direito de a parte constituir novo patrono por meio de substabelecimento ou direito de obter a intimação pessoal de uma testemunha. ${ }^{38}$

Assim, concluirmos que a demanda, os recursos, a contestação, o pedido de tutela sumária, o pedido de produção de provas, etc., são atos postulatórios argumentativos, por pressuporem uma argumentação lógica e um juízo intelectivo relevante, e que os meros requerimentos, relacionados apenas ao regular desenvolvimento do processo, a despeito de postulatórios, são atos de maior simplicidade, e, portanto, não argumentativos.

\subsection{IDENTIFICAÇÃO E CONTEÚDO DA DEMANDA}

Do que foi dito até este momento, podemos afirmar que a demanda, ao lado dos recursos, das defesas e dos requerimentos de tutela de urgência, figura como ato postulatório de natureza argumentativa. Resta-nos, todavia, esclarecer: como a demanda se distingue dos demais? O que faz uma demanda ser uma demanda?

A resposta está em seu conteúdo. Uma demanda, além de representar ato argumentativo, visando a influenciar o juiz a emitir um provimento jurisdicional futuro (ato postulatório e indutivo), caracteriza-se pela manifestação clara e inequívoca da vontade da parte em $(i)$ estabelecer originariamente o objeto litigioso de um processo, inaugurando-o; ou (ii) alterar o objeto litigioso de um processo pendente.

Como veremos, tratando de demandas iniciais ou de demandas ulteriores, o objetivo está em se estabelecer o objeto litigioso de um determinado instrumento estatal de resolução de controvérsias (processo), estipulando, por força dos princípios da inércia, da demanda e da correlação, os limites da futura atuação do juiz.

Um recurso não é uma demanda, porque não representa a vontade da parte em inaugurar novo processo ou tampouco de alterar o objeto de um processo pendente. Do mesmo modo, um ato defensivo, de mera resistência, embora tenha relevância para delimitar o objeto cognitivo a ser enfrentado pelo juiz, não é representado pela vontade de alterar o objeto litigioso do processo. Pelo motivo inverso, podemos afirmar que uma “ação rescisória", por ser responsável por inaugurar novo instrumento estatal de resolução

\footnotetext{
${ }^{38}$ Bruno Silveira de Oliveira aponta para uma distinção na estrutura lógica destas duas classes. Para o processualista, "os atos argumentativos necessitam de razões, motivos que subsidiem a vontade externada (...). Já os requerimentos simples não chegam a tanto, pretendem apenas veicular uma informação, requerendo em seguida que o magistrado a chancele." (O juízo de identificação de demandas..., 2011, p. 43).
} 
de controvérsias, configura uma demanda. Do mesmo modo, são demandas a denunciação da lide, a oposição, a reconvenção e a ação declaratória incidental, por terem o objetivo ou função de alterar o objeto litigioso de processo pendente. Isto, veremos mais pormenorizadamente no Capítulo 5.

É importante notar: não estamos falando de eficácia, mas de conteúdo (manifestação de vontade). Há atos específicos aos quais a lei atribui o efeito de instaurar ou de modificar o objeto litigioso do processo e que, carentes desta manifestação de vontade clara e inequívoca, não podem ser considerados demandas.

Isto ocorre, conforme veremos, e.g. quando o processo de inventário é instaurado pelo juiz, instituindo um objeto litigioso sem demanda ou mesmo quando, em determinados procedimentos especiais, a lei concede a ato defensivo a eficácia de alterar o objeto litigioso. Demanda é demanda porque tem determinado conteúdo inequívoco, conteúdo este que a lei exige e cuja consequência deve ser a instauração ou modificação do objeto litigioso do processo. Isto, contudo, não impede que a lei atribua a mesma eficácia, em casos excepcionais, a outros atos que não são demanda. Tudo isso deverá ser esclarecido mais adiante (cf. itens 5.11 e 5.13).

\subsection{QUE SIGNIFICA INSTAURAR OU ALTERAR O OBJETO LITIGIOSO DO PROCESSO?}

As polêmicas e as dificuldades em se determinar o conteúdo do objeto litigioso do processo serão tratados nos dois capítulos seguintes (Capítulo 2 e Capítulo 3). No entanto, antes disso, é relevante questionar: que significar afirmar que a demanda tem aptidão de instituir ou alterar o objeto litigioso do processo?

O processo, como veremos, dirige-se a diferentes atividades, reconhece por meio de provas a veracidade da alegação das partes em contraditório, analisa a aplicabilidade de determinadas normas jurídicas aos fatos alegados e, ao fim, emite e efetiva um comando: condenando a pagar, fazer ou não fazer, declarando ou (des)constituindo uma relação jurídica.

O objeto litigioso do processo é o mérito, i.e. o material que deverá coincidir com este comando judicial, o consequente da norma jurídica concreta representada pela sentença de mérito. A demanda, por sua vez, veiculará a pretensão da parte que deverá 
determinar o que deverá, ou não, o magistrado determinar em seu comando decisório final. Para Dinamarco:

"mérito é o objeto do processo e reside no petitum contido na demanda, o qual por sua vez expressa duas pretensões a serem decididas pelo juiz (supra, nn. 433, 434 etc.). Ao extinguir o processo sem julgamento do mérito, este está rejeitando a primeira dessas pretensões, a saber, a pretensão ao provimento, sem chegar a manifestar-se sobre a pretensão ao bem. Ao extingui-lo com o julgamento do mérito, ele está acolhendo a pretensão ao provimento, tanto que o emite; e a pretensão ao bem da vida estará sendo acolhida ou rejeitada, conforme o juiz julgue a demanda procedente ou improcedente". 39

Na decisão judicial, muitas questões podem ser solucionadas $e . g$. pode-se decidir a respeito da admissibilidade de provas, de tutelas de urgência, questões prejudiciais e questões preliminares. Porém, nada disso corresponderá ao objeto litigioso do processo, que se restringe ao comando ou ordem ou consequência que o juiz deverá emitir após superar todas estas questões, considerando o conteúdo das demandas formuladas e admitidas no curso do processo.

Por uma opção do direito positivo brasileiro, podemos afirmar que, tratando-se do processo de conhecimento (que é a espécie de processo tratada na presente tese), o objeto litigioso do processo deverá corresponder ao comando decisório que estará apto a sofrer a imutabilização determinada pela coisa julgada material (CPC, art. 467). No entanto, esta correspondência não é obrigatória, podendo variar a depender das escolhas feitas pela lei.

\subsection{ESTRUTURA DA DEMANDA}

Uma vez conceituada a demanda, e devidamente inserida no contexto dos atos processuais postulatórios argumentativos, resta-nos distinguir sua forma de seu conteúdo, é dizer, os meios de exteriorização e os elementos dos quais a demanda é constituída, que a individualizam. ${ }^{40}$

\footnotetext{
${ }^{39} \mathrm{Cf}$. Dinamarco, Instituições de direito processual civil, vol. III, p. 656.

${ }^{40} \mathrm{O}$ objeto de estudos se limitará à análise do processo de conhecimento. Embora parte das premissas possam ser aplicadas ao processo cautelar ao processo de execução e mesmo a alguns procedimentos especiais, optou-se neste trabalho por não tratar destes temas.
} 
A forma, meramente instrumental, é composta pelo conjunto dos meios necessários a exprimir o conteúdo do ato processual, é dizer, dos elementos de tempo, lugar e modo. O conteúdo, por sua vez, é configurado pela manifestação de vontade (o que se almeja), exteriorizada pela forma. ${ }^{41}$ Vejamos.

Demandar significa, antes de tudo, postular: "afirmar um direito em relação a um outro sujeito". ${ }^{42} \mathrm{O}$ conteúdo de toda e qualquer demanda é formado pelo seguintes elementos: (i) pedido: a solicitação de um ato de poder estatal, (ii) partes: por determinado sujeito em face doutro e (iii) causa de pedir: com fundamento na afirmação de um dado direito. $^{43}$

Os elementos da demanda (seu conteúdo) repercutem aspectos da relação de direito material, senão existente, ao menos afirmada pelo demandante. Os sujeitos que identificam a demanda, normalmente, coincidem com os sujeitos ativo e passivo de direitos, presentes na relação alegada (casos de legitimação ordinária). ${ }^{44}$

Os fatos jurídicos que se submetem ao antecedente da norma de direito material (fattispecie), fazendo nascer o direito em disputa, são apontados como a causa que dá fundamento à demanda. $\mathrm{O}$ efeito jurídico decorrente da subsunção do fato à norma (iuris sanctio), por sua vez, identifica o objetivo (fim) da demanda, que deverá ser propiciado por meio dos atos de poder do Estado, postulados pelo demandante. Neste aspecto, Bondioli nos direciona para a existência de uma dualidade:

\footnotetext{
"A demanda tem um sentido formal (ato de apresentação do pedido de tutela jurisdicional) e um sentido material (pretensão formulada em juízo). E tem como elementos constitutivos as partes (a pessoa que pede e a pessoa em face de quem se pede), a causa de pedir (os fatos e os motivos de direito de justificam o pedido) e o pedido (o provimento jurisdicional solicitado e o bem da vida que se tenciona obter)". ${ }^{45}$
}

${ }^{41}$ Bruno Silveira de Oliveira, O juízo de identificação..., 2011, pp. 40-41.

${ }^{42}$ Salvatore Satta, Direito Processual Civil, $7^{\mathrm{a}}$ ed., 1973, trad. Paulo Autuori, p. 171.

${ }^{43}$ Por este motivo, sustenta Bedaque que os "elementos da ação consistem em dados da relação jurídica material utilizados pelo processo para individuar uma ação proposta". Para o processualista, não é possível o estudo do conteúdo da demanda sem referência às vicissitudes de uma dada relação de direito material, de seus sujeitos e de seu objeto: "utilíssima a perfeita compreensão desses elementos, pois é a partir deles que são resolvidos vários dos problemas processuais, como a conexão, a continência, a litispendência e a coisa julgada". (Bedaque, "Os elementos objetivos da demanda à luz do contraditório", Causa de pedir e pedido no processo civil, 2002, p. 28).

${ }^{44}$ Tal coincidência apenas não se dá nos casos de legitimação extraordinária, nos quais a lei atribui a sujeito que não figura como titular da relação de direito material a faculdade ou o dever de propor demanda em favor de outrem.

${ }^{45}$ Cf. Bondioli, Reconvenção no processo civil, 2009, p. 22. 
Nos tópicos seguintes pretendemos propor critérios para distinguir a forma do conteúdo da demanda, para que possamos, por conseguinte, explicitar como este segundo elemento (conteúdo) é o único capaz de identificar uma demanda como tal.

\subsection{DEMANDA: FORMA E CONTEÚDO}

Tradicionalmente, a forma dos atos processuais é classificada em duas categorias: (i) elementos intrínsecos, que se referem à sua substância física, ao modo de ser do ato (forma em sentido estrito); e (ii) elementos extrínsecos, que se referem ao tempo e ao local onde se realizou a ação ou omissão (forma em sentido amplo).

A primeira categoria contempla o conjunto dos meios necessários a exprimir seu conteúdo, tratando de meios físicos (forma escrita ou forma oral) e linguísticos (regras do idioma). ${ }^{46}$

Do ponto de vista da linguagem, os atos processuais são representados pela palavra, como os atos jurídicos em geral e ainda que seja admitido o uso de expressões em idiomas estrangeiros, a forma de expressão da palavra é a língua portuguesa (CPC, arts. $139,151,156$ e 157).

Em acréscimo, dependendo da fase processual e da natureza do procedimento (oral, escrito ou misto), a manifestação da palavra pode ser tanto oral quanto escrita, sendo certo que, para efeitos de documentação, quando realizados oralmente, os atos processuais deverão ser reduzidos a termo, podendo também serem registrados por meio eletrônico (CPC, arts. $169, \S \S 2^{\circ}$ e $\left.3^{\circ}, 417,457\right) .{ }^{47}$

A segunda categoria, por sua vez, contempla as coordenadas que indicam onde e quando o ato é realizado. O critério lugar está estampado no art. 176 do CPC; os atos postulatórios normalmente ocorrem na sede do juízo, todavia, podem "efetuar-se em outro lugar, em razão de deferência, de interesse da justiça, ou de obstáculo arguido pelo interessado e acolhido pelo juiz" ${ }^{48}$ e o requisito tempo, por fim, pressupõe o estudo dos

\footnotetext{
${ }^{46}$ Por esta razão, Bruno Silveira de Oliveira sustenta que a expressão modo de ser deveria ser substituída por meios de expressão, (O juízo de identificação de demandas..., 2011, p. 59)

47 A respeito da oralidade e do uso da palavra escrita no Código de Processo Civil, cf. José Roberto do Santos Bedaque, Samuel Brasil Jr. e Bruno Silveira de Oliveira, “A oralidade no processo civil brasileiro", Processo Civil: novas tendências, p. 415 e ss.

${ }^{48}$ Cf. Cintra, Grinover e Dinamarco, Teoria geral..., $17^{\mathrm{a}}$ ed., p. 323.
} 
prazos e das fases processuais; ${ }^{49}$ "espaço de tempo dentro do qual o ato processual deve ser praticado". 50

Até este momento, tudo parece muito claro. Ocorre que estas afirmações, a despeito de tomadas como auto esclarecedoras, não são suficientes para distinguir a forma de um ato postulatório de seu conteúdo.

Quando falamos do lugar e do tempo, a distinção é mais clara, pois os elementos tratados são externos ao ato, bastando identificar quando e onde o ato se materializou; as coordenadas geográficas e temporais da exteriorização do ato, que não se confundem nem poderiam se confundir - com o seu modo de ser ou conteúdo. O momento, fase, dia ou hora, ou local de realização do ato, foro, tribunal, residência, é bem distinto da função ou da finalidade do ato.

Quando tratamos de distinguir, no entanto, o modo de ser (forma em sentido estrito) do conteúdo do ato processual postulatório, tal simplicidade se arrefece. Ora, qual é a distinção entre um pedido, manifestação linguística formal que se submete ao requisito de forma do art. 282, IV, do CPC e cujo desatendimento gera a inépcia da petição inicial (forma em sentido estrito), de um pedido de tutela jurisdicional, manifestação de vontade, i.e. pretensão, que representa o conteúdo do ato postulatório de demandar? Como é possível distinguir a forma (em sentido estrito) de seu conteúdo?

A pergunta é relevante para os propósitos do presente trabalho, conforme veremos a seguir, especialmente porque há atos processuais de mesmo conteúdo, com forma distinta, assim como há atos processuais de mesma forma, com conteúdo distinto. Circunstância que gera incertezas.

Para uma resposta, devemos fazer breve digressão a respeito da estrutura do ato de demandar, de modo a identificá-lo como um ato linguístico: um agir por meio de palavras e, a partir destes elementos linguísticos, identificaremos o conteúdo do ato, diferenciando-o de sua forma.

\footnotetext{
${ }^{49}$ Os prazos processuais podem ser classificados em legais e judiciais. Os primeiros são estipulados diretamente pela lei, e não dependem de determinação judicial. Os segundos são fixados pelo juiz, nas hipóteses em que a lei processual se mostra omissa (CPC, art, 177). Além disso, podemos falar em prazos comuns e particulares. Os comuns são assinados contemporaneamente a mais de um sujeito processual. Os particulares, por sua vez, se estabelecem individualmente. Há, ainda, prazos próprios e impróprios. Os primeiros são associados à preclusão. Se não realizado o ato dentro do prazo, não mais poderão ser realizados. Os segundos, por sua vez, ainda que intempestivos, terão plena eficácia. Por fim, fala-se em prazos dilatórios e peremptórios. Os prazos dilatórios comportam prorrogação, que pode ser convencionada entre as partes (CPC, art. 181). Os peremptórios, por sua vez, são tidos como improrrogáveis, não podendo ser alterados mediante a manifestação de vontade (CPC, art. 182). (Cf. Chiovenda, Instituições..., vol. III, 1945, p. 19).

${ }^{50}$ Cf. José Frederico Marques, Instituições..., vol. II, p. 266; e Roberto Poli, "Sulla sanabilità...", Rivista di diritto processuale, 1996, p. 448.
} 


\subsection{DEMANDA: AGIR POR MEIO DE PALAVRAS}

A linguagem, na forma mais comum, é utilizada para a mera descrição de fatos ou ações pretéritas, tal como um botânico faz em relação às plantas que estuda, ou mesmo que um constitucionalista faz a respeito do texto da Constituição ou das decisões da Suprema Corte.

Agir por meio de palavras, por sua vez, é fazer algo específico que somente pode ser feito com linguagem, é valer-se da linguagem para uma função distinta daquela meramente descritiva. Coube à filosofia da linguagem identificar que às palavras não cabe a simples função de nomear as coisas, contrariando pensamento filosófico então vigente. ${ }^{51}$

No âmbito regulado pelo direito, detectou-se que expressões como "Declaro a sessão aberta", "Sanciono a lei", "Condeno o réu”, etc. não informam ou descrevem absolutamente nada, é dizer, não afirmam haver sido a sessão aberta, a lei sancionada ou mesmo o réu condenado, mas, na verdade, são elas próprias o objeto da abertura, da sanção e da condenação. Nos casos tratados, enunciar a frase não é nem descrever aquilo que se está a fazer nem tampouco afirmar o que se faz, mas efetivamente "o fazer"; “abrir", "sancionar" e "condenar". 52

Esclarecido isso, cabe-nos questionar: de que modo esta ideia se relaciona com os propósitos do presente trabalho?

Ora, a demanda é ato que se insere nesta categoria de atos-de-fala, é da sua natureza que o agente se valha da linguagem para fazer algo: argumentar, sustentar uma posição e pleitear uma decisão judicial.

Embora na demanda possa ser possível identificar o uso da linguagem para descrição (i.e. causa de pedir), é do seu conteúdo, do pedido que a identifica como tal (que caracteriza uma demanda como demanda), o uso da linguagem para realizar uma ação específica: pleitear a tutela jurisdicional, com o objetivo de que efeitos jurídicos previamente convencionados pela lei sejam produzidos.

Para tanto, pressupõe-se $(i)$ o uso de signos linguísticos dentro de certo contexto morfológico, que pode ser um idioma ou mesmo um sinal construído a partir de gestos; e

\footnotetext{
${ }^{51}$ Cf. John L. Austin, How to do things with words, 1962, p. 12.

52 Austin usa a palavra "claim", equivalente inglesa da expressão demanda para definir um dos exemplos que cita de atos exercitivos. (cf. How to do things with words, 1962, p. 156). A respeito da relação entre atos postulatórios e o conceito de atos exercitivos em Austin, cf. Bruno Silveira de Oliveira, $O$ juízo de identificação de demandas..., 2011, p. 56, nota 42.
} 
(ii) a utilização de um meio físico de expressão, seja este escrito ou oral. Pressupõe-se, ainda, nos termos das regras acima indicadas, a existência de um procedimento convencional, com efeitos convencionados pela lei. ${ }^{53}$

A demanda é uma demanda porque direcionada ao Estado e porque elaborada, dentro de determinadas condições, por agente autorizado para tanto. Além disso, é uma demanda porque apresenta um conteúdo linguístico específico, que a caracteriza como tal (objetiva o convencimento). ${ }^{54}$

${ }^{53}$ A respeito do agir por meio de palavras, cf. John L. Austin, How to do things with words, $2^{\mathrm{a}}$ ed., p. 155; e John R. Searle, Expressão e significado..., trad. Ana Cecília G.A. de Camargo e Ana Luiza Marcondes Garcia, p. 21. Os atos processuais normalmente se dão da forma oral ou escrita, mas é possível cogitar o uso da linguagem de sinais para a realização de um ato processual postulatório não argumentativo, e.g. o requerimento feito por advogado em sessão de julgamento para a realização de sustentação oral, após o pregão feito por oficial de justiça. Nesse caso, o advogado não precisa formular requerimento oral ou escrito, de modo que o seu levantar e dirigir-se à tribuna leva um significado inequívoco a respeito de sua intenção, passível inclusive de indeferimento pelo órgão jurisdicional.

54 Austin divide a análise dos atos de fala em (a) ato locucionário, ato de dizer algo, que consiste na exteriorização de signos linguísticos dotados de um sentido; (b) ato ilocucionário, representado pela intenção do agente ao realizar o ato; e (c) ato performativo ou perlocucionário, representado pelo efeito causado pelo ato de fala no interlocutor, ao qual $o$ ato se dirige. Ao tratamos da demanda, preocupamo-nos fundamentalmente com o ato perlocucionário, na medida em que avaliamos a capacidade deste ato gerar o convencimento do juiz (efeito causado no interlocutor). (cf. Osly da Silva Ferreira Neto, Ações tributárias coletivas, p. 36).

A identificação do ato perlocucionário levou Austin a, em um segundo momento, examinar as condições específicas que tornariam possíveis os diversos atos em que dizer corresponderia a realização de um ato. Entendeu que, independentemente de seu conteúdo, as enunciações performativas ou perlocutórias adquiririam sentido e eficácia somente se determinadas regras fossem observadas. Austin percebeu que fazer algo por meio de palavras não pressupõe, apenas, o dizê-lo. Exemplifica que o ato de apostar não é realizado simplesmente pela dicção das palavras "Eu aposto, e etc.". Alguém poderia ser bem sucedido em dizer tais palavras, e mesmo assim poderíamos duvidar do fato dele haver efetivamente "apostado", realizado a aposta, para tanto, bastaria que a enunciação tivesse ocorrido após a corrida para que passemos a ter certeza de que tais dizeres, de fato, não configurariam uma aposta.

Aposta, para ser aposta, tem de ocorrer no momento certo, no local certo e ser realizada pela pessoa certa em face da pessoa certa. Isto vale para todo e qualquer ato perlocutório. Além de dizer palavras chamadas "performativas", concebidas como aquelas que tem por objetivo realizar uma ação, muitas outras coisas devem se perfilhar para que a ação seja "felizmente" realizada. Não apenas o conteúdo da ação (enunciação) deve ser condizente com a finalidade do ato, mas também este deve ser exercido dentro de um contexto adequado, que permita que o ato exerça sua função. As regras são, portanto, as seguintes.

Em primeiro lugar, (AI) deve existir um procedimento, reconhecido por convenção, e que tenha também um efeito previamente convencionado, compreendendo o enunciado de determinadas palavras por determinadas pessoas em certas circunstâncias. A palavra exercerá sua função apenas se contextualizada a uma determinada situação onde tenha aptidão de gerar o sentido para o qual foi programada, de modo que produza os efeitos convencionados àquele determinado ato.

Em segundo lugar, (A2) é preciso que em cada caso as pessoas e as circunstâncias sejam as que convém para que se possa invocar o procedimento em questão. Além da convenção quanto ao ato e aos efeitos, é necessário que os agentes tenham "competência" ou "legitimidade" para realizar o ato, façam parte daquele contexto linguístico. A convenção quanto ao procedimento e aos efeitos, no entanto, não basta. É necessário (BI) que todos os agentes - sujeitos envolvidos no discurso - executem o procedimento ao mesmo tempo corretamente e que este procedimento seja exercido na sua (B2) integralidade.

Em terceiro lugar, Austin trata de elementos que estão relacionados, não com o ato em si mesmo, sua constituição, mas com o atendimento da finalidade do ato, afirmando que (ГI) "é preciso que a pessoa que toma parte no procedimento (e deste modo o invoca) tenha, de fato, estes pensamentos ou sentimentos, e que os participantes tenham a intenção de adotar o comportamento implicado". Além disso, (Г2) devem depois, de fato, comportar-se assim." O descumprimento de qualquer uma das regras mencionadas acima levará à "infelicidade" do ato de fala (infelicity). 
Neste agir, frases e orações são constituídas a partir da relação entre palavras que, por sua vez, são constituídas a partir da relação entre letras, signos linguísticos. Todas estas combinações pressupõem a utilização e o conhecimento de regras morfológicas, tanto pelo agente quanto pelo interlocutor, e dependem de um suporte físico, um meio pelo qual as letras, as palavras, as frases e as orações sejam veiculados (registro físico da ação). ${ }^{55}$

$\mathrm{Na}$ demanda, as convenções normativas determinam a utilização da linguagem em conformidade com o vernáculo, e pela utilização de um meio físico específico, determinado por normas de direito positivo, que pode ser o meio oral (Lei 9.099/95, art. 14) ou o meio escrito (CPC, art. 282).

O conjunto representado por estes elementos, $(i)$ uso da linguagem (estruturas morfológicas utilizadas) e (ii) manifestação física do ato (oral ou escrita), representa a sua forma (em sentido estrito), seu modo de ser. Sendo a demanda um ato linguístico, é natural que sua forma (forma em sentido estrito) seja constituída da soma dos elementos linguísticos, devidamente registrados em um suporte físico.

Esta forma não é unívoca, admite variações. Segundo o direito positivo, as regras morfológicas devem atentar ao vernáculo (CPC, arts. 139, 151, 156 e 157; CPP, arts. 193, 223, 236 e 784, $\S 1^{\circ}$ ). São sempre os parâmetros da língua vigentes dentro de um determinado contexto comunicacional que vincularão os sujeitos do processo. E não podendo os atos serem realizados na língua portuguesa, tal como o depoimento pessoal de parte estrangeira ou de testemunha que não domina a língua, deverão ser submetidos à tradução (CPC, art. 151).

O registro físico, por sua vez, aceita múltiplas variações. Inicialmente, a lei admite a veiculação do ato pela forma escrita e pela forma oral (Lei 9.099/95, art. 14). E mesmo dentro da forma escrita são admitidas variantes i.e. a demanda inicial no procedimento

Há diferenças consideráveis se o descumprimento diz respeito às quatro regras contidas nas letras "A" e "B" ou se o descumprimento das duas regras contidas na letra " $\Gamma$ ". O descumprimento das duas primeiras impedirá a configuração do próprio ato (misfire), assim como se se celebrasse o casamento de pessoas que já são casadas, se a cerimônia fosse celebrada por quem não possua autoridade para tanto ou mesmo se a noiva dissesse sim e o noivo não. No entanto, no caso da letra " $\Gamma$ " o ato não deixa de existir pelo simples fato de o autor não haver manifestado seus verdadeiros sentimentos ou pelo fato de o destinatário não haver reais intenções de cumprir ou não haver cumprido a ação desejada (abuse). O que Austin chama de "infelicidade" traduz-se, portanto, em nossa linguagem jurídica em dois fenômenos distintos: a invalidade (misfire) e a inexecução ou descumprimento (abuse). (Cf. John L. Autin, How to do things with words, 1962, pp. 14-16).

$55 \mathrm{O}$ meio físico registra o ato de fala e permite que este seja recebido - e compreendido - pelo interlocutor. $\mathrm{O}$ ato de falar é, portanto, efeito da capacidade do agente em executar o ato comunicacional (intelectiva e fisicamente), ao gerar ondas sonoras por meio da trepidação das cordas vocais (sons da palavra falada) ou causar registros no papel por meio do atrito e do despejo de tinta proveniente de uma caneta (palavra escrita). Por sua vez, é causa da compreensão desse evento pelo interlocutor. É porque o ato foi exercido e veiculado por um determinado meio físico que sua compreensão foi viabilizada pelo destinatário deste ato. Cf. Bruno Silveira de Oliveira, O juízo de identificação de demandas..., 2011, pp. 57-58. 
comum ordinário deve respeitar, necessariamente, requisitos específicos do art. 282 do CPC (modelo formal), alterando-se o procedimento, tal como o comum sumário ou outro procedimento especial, requisitos distintos são apresentados (e.g. CPC, art. 275) e demandas ulteriores, como a reconvenção, a denunciação da lide e a oposição, admitem sutis distinções na sua exteriorização física (ex vi do CPC, arts. 56, 70 e 315). ${ }^{56}$

Todos estes são apenas meios, e não podem ser confundidos com os motivos nem tampouco com os objetivos do ato (funções da locução). ${ }^{57} \mathrm{~A}$ forma, por admitir diferentes feições, por sua variabilidade, pode auxiliar em alguns casos, mas não é referência para a identificação do conteúdo da demanda. ${ }^{58}$

A doutrina refere-se ao conteúdo como o elemento restante do ato, excluída a plenitude de sua forma, depois de desconsiderado o meio físico e a estrutura linguística do ato, o conteúdo é exatamente o sentido extraído a partir do ato linguístico, i.e. o "significado com que se preenche, em concreto, aquele modelo invariável de sujeitos, causa, e pedido". 59

Em conclusão, podemos afirmar que forma em sentido estrito de uma demanda é caracterizada pela exteriorização, por um meio físico e por meio de linguagem, de um pedido, de uma causa de pedir e das partes. Conteúdo, por sua vez, é exatamente o significado desse pedido, configurado por suas razões de ser e sujeitos. Uma é a ação linguística registrada, normalmente, no papel (locução), o outro são a vontade, o motivo e as pessoas.

\footnotetext{
${ }^{56}$ A este respeito, podemos afirmar que diferentes atos processuais possuem diferentes requisitos de admissibilidade. Nesse sentido, com apoio no pensamento de Rosemberg e Calmon de Passos, Fredie Didier Jr. defende que a admissibilidade não deve ser analisada, exclusivamente, em relação ao procedimento, aplicando-se também a cada ato processual, individualmente. Cf. Fredie Didier Jr. Pressupostos processuais e condições da ação..., pp. 25-28. Isso, contudo, não significa que - considerando aspectos da relação de direito material - o juiz estaria impedido de flexibilizar o procedimento de ofício nestes casos, cf. Gajardoni, Flexibilidade procedimental, p. 181.

${ }^{57}$ Cf. John L. Austin, How to do things with words, 1962, p. 98.

${ }^{58}$ Cf. Bruno Silveira de Oliveira, O juízo de identificação de demandas..., 2011, p. 59.

${ }^{59}$ Para Crisanto Mandrioli, "quando se fala de forma do ato jurídico em geral, entende-se a manifestação do ato, o seu manifestar-se em um comportamento exterior objetivamente individualizável e estimável. A essa noção de forma se sói, pois, contrapor aquela de conteúdo". (Corso di diritto processuale civile, $12^{\mathrm{a}}$ ed., v. I, p. 381, trad. livre). No mesmo sentido, Cf. Bruno Silveira de Oliveira, O juízo de identificação de demandas..., 2011, p. 59.
} 


\subsection{DEMANDA E EXIGÊNCIAS AXIOLÓGICAS QUANTO AO FORMALISMO}

Definido o que é demanda, e feita distinção entre sua forma e conteúdo, resta-nos agora delimitar o especial papel que este ato processual exerce no sistema jurídico. Saber o que é demanda e, mais especificamente, identificar uma demanda, em distinção a outros atos processuais, é relevante apenas porque a demanda exerce uma função única no sistema.

Todos os demais atos processuais, inclusive os de natureza postulatória, somente existem porque antes foi formulada uma demanda. Via de regra, são atos simplesmente convenientes (e.g. defesa), não essenciais, que têm a eficácia de prolongar a litispendência (e.g. recursos), mas, salvo exceções expressamente previstas na lei, não podem veicular ou alterar o objeto litigioso do processo.

Ação e demanda, portanto, a despeito de não tratarem de conceitos sinônimos, representam duas faces de uma mesma moeda. Ação é um poder, abstrato e com fundamento na ordem constitucional (inafastabilidade da tutela jurisdicional), que garante ao jurisdicionado, não apenas o direito provocar a Jurisdição, mas também de participar dela de forma efetiva e de obter resultados adequados. ${ }^{60}$ Demanda, por sua vez, é o ato concreto e inaugural do exercício desse amplo poder estatal. Sem demanda, a Jurisdição não se movimenta e não exerce sua função. ${ }^{61}$

A Constituição Federal prevê em seu art. $5^{\circ}, \mathrm{XXXV}$, de forma ampla e genérica, a garantia de acesso à justiça e de inafastabilidade da tutela jurisdicional. Trata-se de uma efetiva promessa, elaborada no sentido de que os conflitos sociais i.e. toda e qualquer pretensão resistida de determinado sujeito de direitos e quaisquer queixas que possam surgir a respeito da aplicação do direito, poderão ser levadas à apreciação do Judiciário.

Em primeiro lugar, o acesso à justiça pressupõe a existência de diferentes mecanismos para a tutela dos direitos, inclusive para controle dos atos editados pelo próprio Estado, tais como o mandado de segurança individual e coletivo, o mandado de injunção, o habeas-data, a ação popular, a ação direta de inconstitucionalidade, a ação civil

\footnotetext{
${ }^{60}$ Para Proto Pisani: “a ação não é outra coisa senão um complexo de poderes do juiz destinados a se envolverem em um procedimento em contraditório". (Lezioni di diritto processuale civile, $5^{\mathrm{a}}$ ed., p. 213, trad. livre).

${ }^{61}$ Para Dinamarco: "Demanda é um ato e não se confunde com ação, que é um direito, ou poder. Não é correto dizer que se propõe uma ação, mas uma demanda: é esta que se considera proposta, ou seja, posta diante do juiz à espera de satisfação”. (Instituições de direito processual civil, vol. I, p. 301).
} 
pública e os juizados especiais (CF, art. 5, LXIX a LXXIII; art. 102, I, "a"; art. 129, II e art. 98, I).

Em segundo lugar, há no texto constitucional um "conjunto de garantias destinadas a produzir um processo équo, cujo resultado prático realize a justiça". ${ }^{62} \mathrm{~A}$ Constituição não se limita a prescrever um direito ao instrumento e aos mecanismos formais do processo, mais do que isso, garante acesso ao devido processo constitucional, com respeito ao contraditório, à ampla defesa, à publicidade, à imparcialidade, à vedação da prova ilícita, etc. ${ }^{63}$

A garantia de acesso à justiça, e as promessas constitucionais correlatas, representam o fenômeno analisado sob o prisma do jurisdicionado, que é sujeito ativo de um direito à ordem jurídica justa, antes de ter, ou não ter, direito à tutela jurisdicional (direito ao processo vs. direito ao bem da vida). Esta posição ativa do jurisdicionado, uma vez proposta a demanda, se converte - na sua contraparte necessária - em dever para o Estado-jurisdição (posição passiva), que se obriga a cumprir as referidas promessas, não apenas concedendo meios, mas produzindo resultados adequados à luz da ordem positiva.

O cumprimento destas promessas, no entanto, sofre limitações pela própria ordem constitucional, que estipula parâmetros mínimos a serem respeitados pela Jurisdição quando busca cumprir seus deveres (acesso à ordem jurídica justa). Estas limitações, conforme a lição de Dinamarco, servem "para que o exercício desta [Jurisdição] se dê sempre por meios socialmente convenientes e juridicamente idôneos, sem perder de vista a mais profunda razão de ser de todo o sistema, que é a existência de conflitos a dirimir". ${ }^{64}$

A Jurisdição tem de buscar a verdade e a celeridade, mas não a qualquer custo, na medida em que somente pode se pautar em provas obtidas por meios lícitos e em total observância ao contraditório, ampla defesa, inércia, motivação, imparcialidade, publicidade, isto é, ao devido processo legal (slogan ou princípio-síntese). ${ }^{65}$

${ }^{62}$ Cf. Dinamarco, Instituições de direito processual civil, vol. I, p. 110.

${ }^{63} \mathrm{Cf}$. Bedaque, "Os elementos objetivos da demanda à luz do contraditório", Causa de pedir e pedido no processo civil, 2002, p. 14.

${ }^{64} \mathrm{Cf}$. Dinamarco, Instituições de direito processual civil, vol. I, pp. 111.

${ }^{65}$ Estas circunstâncias em dados casos acabam por limitar ou mesmo impedir o cumprimento das promessas constitucionais. Muitas vezes a necessidade de respeito às garantias constitucionais do processo entra em colisão com a promessa de efetividade, e.g. a vedação às provas ilícitas afasta o processo da verdade, impedindo que fatos conhecidos sejam tomados com premissa do julgamento, e o contraditório, muitas vezes, retarda seu resultado, por exigir um diálogo mais completo e que, por consequência, deve levar mais tempo, entre outros casos. Nesse sentido é a lição de Dinamarco: "As próprias garantias constitucionais acima indicadas como promessas periféricas à promessa central comportam exame pelo seu próprio lado negativo, constituindo limitações ao exercício da jurisdição. Por exemplo, em clima de Estado-de-direito impõe-se ao juiz a observância da liberdade de conduta dos litigantes no processo e da efetiva disponibilidade dos meios processuais instituídos no sistema, tudo em aplicação da garantia constitucional do due process of 
Este quadro de limitações, conforme demonstraremos, relaciona-se com a finalidade da demanda no sistema processual, especialmente por força da inércia e da correlação, e justifica o papel especial que este ato tem em provocar a atividade jurisdicional.

O princípio do contraditório fundamenta-se no binômio informação-reação. Informação adequada é pressuposto de qualquer reação efetiva, para que seja possível se insurgir, ou mesmo se manifestar adequadamente em relação a alguma coisa, é antes fundamental o conhecimento a respeito daquilo contra o que se reage ou se manifesta. Conforme leciona Dinamarco:

"a efetividade das oportunidades para participar depende sempre do conhecimento que a parte tenha do ato a ser atacado. O sistema inclui, portanto, uma atividade, posta em ação pelo juiz e seus auxiliares, consistente na comunicação processual e destinada a oferecer às partes ciência de todos os atos que ocorrem no processo". ${ }^{66}$

Assim, no processo, antes de poderem reagir, as partes devem ter acesso a informações, ${ }^{67}$ devem poder saber a respeito do que devem se manifestar, tendo prévia ciência dos atos do juiz, bem como das alegações, das provas apresentadas e dos pedidos formulados pelas partes. ${ }^{68}$

Estas informações são passadas por variados atos de comunicação, em especial, pelo ato de citação (CPC, art. 213), que traz ao demandado o conhecimento da demanda inicial, e demais atos de intimação (CPC, arts. 234), que levam às partes o conhecimento das decisões, dos despachos judiciais e das manifestações dos demais sujeitos parciais e imparciais do processo. ${ }^{69}$

law. A observância das normas sobre procedimento é penhor de idoneidade no exercício da jurisdição e ao juiz não é lícito omitir atos essenciais ou praticá-los por forma diferente da ditada na lei, a dano dos litigantes; as regras de competência também limitam o exercício da jurisdição, porque o ato realizado por juiz diferente daquele indicado pela Constituição ou pela lei, com ultraje a uma das garantias do juiz natural (infra, n. 81), é ilegítimo e por isso fadado a possível nulidade; etc”. (Instituições de direito processual civil, vol. I, pp. 110-111).

${ }^{66}$ Instituições de direito processo civil, vol. I, p. 216.

${ }^{67}$ A técnica processual, de modo a valorizar essa garantia, adota o consagrado sistema de informaçãoreação. Dinamarco, em resumo, afirma que, "para cumprir a exigência constitucional do contraditório, todo modelo procedimental descrito em lei contém e todos os procedimentos que concretamente se instauram devem conter momentos para que cada uma das partes peça, alegue e prove". (Instituições..., vol. 1, p. 215).

${ }^{68}$ Para Dinamarco, "a efetividade das oportunidades para participar depende sempre do conhecimento que a parte tenha do ato a ser atacado. O sistema inclui, portanto, uma atividade, posta em ação pelo juiz e seus auxiliares, consistente na comunicação processual e destinada a oferecer às partes ciência de todos os atos que ocorrem no processo". (Instituições..., vol. I, p. 216).

${ }^{69}$ Sidnei Amendoeira Jr. Poderes do juiz..., p. 65. No mesmo sentido, cf. Edoardo F. Ricci, Princípio do contraditório e questões..., p. 497. 
De posse dessas informações, as partes potencialmente afetadas pelo processo devem ter condições de exporem suas razões em juízo, sustentarem teses, manifestarem-se a respeito dos argumentos das partes contrárias e participarem da produção das provas, entre outros. $^{70}$

Ora, a ausência de informações, ou mesmo uma informação imprecisa ou incompleta, inviabilizaria o contraditório, especialmente quando tratamos do ato inaugural, responsável por delimitar seu objeto litigioso (demanda).

A incerteza a respeito dos fundamentos da demanda, ou mesmo a respeito da efetiva extensão do pedido formulado pela parte, prejudica o contraditório, e é reconhecida pela própria técnica processual como causa para a invalidação dos atos processuais (CPC, art. 283 - inadmissibilidade da demanda). Ao exigir a narrativa de fatos, de uma causa de pedir e de um pedido (CPC, art. 282, III e IV), a lei se justifica pela necessidade de que o réu, ao ter acesso ao conteúdo da demanda, possa compreender a extensão da vontade manifestada e, desse modo, possa escolher se se defende, ou não. E optando por se defender, possa fazê-lo da forma mais adequada. ${ }^{71}$

Uma demanda deficientemente proposta, sem as citadas exigências ou sem clareza quanto aos fatos ou ao pedido, torna incerto o objeto litigioso do processo, prejudicando o contraditório e, por consequência, exigindo a incidência dos artigos 284 (saneamento) e 295 (indeferimento liminar) do Código de Processo Civil (cf. Capítulo 4).

Mas isso não é só. Além de o conteúdo da demanda dever ser inequívoco, a presente tese trata de outro problema: da necessidade de o ato ser inequivocamente identificável (juízo de identificação) como demanda, para que a parte afetada possa ter certeza a respeito dos exatos efeitos que este ato tem aptidão para produzir, à luz da técnica processual (cf. Capítulo 5). Estes pontos serão tratados pormenorizadamente adiante.

\footnotetext{
70 A exigência constitucional não se refere, especificamente, ao exercício do contraditório, mas à oportunidade, concedida ao demandado, para que este responda à demanda. Leciona Tereza Wambier que "habitualmente, liga-se à idéia de contraditório à oportunidade que deve necessariamente ser conferida às partes para que estas peçam, façam alegações e produzam provas ligadas ao direito que afirmam ter. Assim, para que se entenda ter sido respeitado o contraditório num processo, numa visão mais tradicional, basta que às partes tenham sido dadas estas chances ou oportunidades, ainda que não tenham sido utilizadas". (Anotações sobre o princípio do contraditório..., p. 73). No mesmo sentido, cf. Luigi Paolo Comoglio. "Giurisdizione e processo...,", Riv. Trim. Dir .e Proc. Civ., 1994, pp. 1081-1082; Edoardo F. Ricci, Princípio do contraditório e questões..., p. 495; Barbosa Moreira, "Le noveau Code de Procedure Civile vu par un juriste brésilien", Temas... Quinta Série, p. 43; Bedaque, Efetividade do processo..., 2006, p. 481 e ss.; e Sidnei Amendoeira Jr., Poderes do juiz..., p. 65.

${ }^{71}$ Para Barbosa Moreira, "la garantie du contraditorie signifie essentiellemente que le demandeur et le defenseur doivent jouir tous les deux de la possibilitté effective de participer au déroulement du procès, d'exposer leurs raisons au juge, d'apporter leurs allégations, de presenter leurs observations sur les arguments de l'adversaire et sur le preuves apportées par celui-ci ou ordonnnées d'office" ("Le noveau Code de Procedure Civile vu par un juriste brésilien”, Temas...: Quinta Série, p. 42).
} 


\section{ESTUDOS SOBRE O CONTEÚDO DA DEMANDA}

\subsection{OBJETO DO PROCESSO E OBJETO LITIGIOSO DO PROCESSO}

No presente trabalho já manifestamos uma preocupação principal, manter a congruência semântica dos conceitos utilizados e tentar reduzir, ao máximo, a ambiguidade na terminologia utilizada. Por este motivo, antes de adentrarmos ao conceito de "objeto litigioso do processo", precisamos esclarecer do quê exatamente estaremos tratando. ${ }^{72}$

Sydney Sanches, em artigo sobre o tema, asseverou os problemas que tanto o direito quanto a filosofia têm em determinar o conceito de objeto, ora referindo-se à coisa, peça, artigo de venda, assunto, matéria, motivo, causa, objetivo, fim a que se mira, ora referindo-se a "aquilo que é pensado, por oposição ao sujeito ou ser pensante". ${ }^{73}$

Cuidando especificamente do objeto do processo, o autor ressalta a ambiguidade da expressão, afirmando que ela pode designar tanto, $(i)$ conforme o fez Pontes de Miranda e Cintra-Grinover-Dinamarco, a finalidade do processo (ou da relação jurídica processual), que seria "a prestação jurisdicional, a que se obriga o Estado ou, mais proximamente, o juiz, por ele"; ${ }^{74}$ quanto (ii) a matéria, o assunto ou o tema de um determinado processo, que seria representado pela manifestação de vontade expressa pela parte (pedido) e que seria de algum modo identificável. ${ }^{75}$

O primeiro sentido mencionado relaciona-se ao tema dos escopos do processo e, portanto, diz respeito à teoria geral do processo e ao estudo da instrumentalidade, sem pertinência direta para o presente trabalho. Quanto ao segundo sentido, no entanto, há outra ambiguidade a ser solucionada, de modo que o "tema" ou "assunto" a que se refere o processo (objeto do processo em sentido lato) encampa "tudo aquilo que se apresenta à intelecção do juiz e, a final, seja determinante da atividade jurisdicional”.

\footnotetext{
${ }^{72}$ A respeito do conceito de objeto do ponto de vista da atividade gnosológica, cf. Miguel Reale, Filosofia do direito, $18^{\mathrm{a}}$ ed., p. 175 e ss.

73 Cf. Sydney Sanches, "Objeto litigioso do processo e objeto litigioso do processo", in Revista de Processo 13, 1979, p. 31 e ss.

${ }^{74}$ Cf. Pontes de Miranda, Comentários ao Código de Processo Civil, t. III, p. 12; e Cintra-GrinoverDinamarco, Teoria Geral do Processo, $17^{\mathrm{a}}$ ed., p. 252.

75 Cf. Sydney Sanches, "Objeto litigioso do processo e objeto litigioso do processo", in Revista de Processo 13, 1979, p. 31 e ss.
} 
Importa dizer que é tema do processo (e deverá ser considerado pelo juiz), tanto as (ii.1.) matérias de defesa (exceções) alegadas pelo réu e as demais circunstâncias que serão objeto da cognição (análise cognitiva do juiz), a respeito das quais este está obrigado a se manifestar (objeto cognitivo do processo); quanto (ii.2) aquilo que deverá ser objeto principal de decisão (iudicium) e da coisa julgada material (objeto litigioso do processo). ${ }^{76}$

Por isso, objeto cognitivo do processo e objeto litigioso do processo são conceitos completamente distintos. O primeiro diz respeito às questões (pontos controvertidos de fato e de direito) que deverão ser solucionadas pelo juiz, de modo que possa julgar a causa e conceder a tutela jurisdicional (ii.1.), o segundo, por sua vez, diz respeito a matéria, aos elementos do processo aptos a individualiza-lo (diferenciar uma causa de todas as outras), delimitando o objeto da prestação jurisdicional, normalmente relacionado ao dispositivo da sentença e às transformações na realidade que esta terá aptidão em provocar, dentre as quais a coisa julgada material (ii.2). ${ }^{77}$

Desse modo, e com o objetivo de evitar ambiguidades, no presente trabalho abandonaremos o termo objeto do processo e nos valeremos apenas da expressão objeto cognitivo do processo, para designar o sentido descrito no item “i.1." e objeto litigioso do processo, para designar o sentido mais estrito indicado no item "ii.2", o qual se relaciona com o mérito e com o objeto principal da decisão e da coisa julgada e que, conforme veremos a seguir, foi influenciado pela expressão alemã Streitgegenstand.

Outra observação, ainda de ordem metodológica, diz respeito ao fato de que o presente trabalho cuida da demanda e do objeto litigioso do chamado processo de conhecimento. Ainda que parte das conclusões sejam aplicáveis ao processo cautelar e ao processo de execução, estes não serão objeto de análise da presente tese.

Dito isto, nos itens seguintes, trataremos de delimitar o sentido da expressão objeto litigioso do processo, apresentando algumas referências históricas relevantes para a formação dos conceitos.

\footnotetext{
${ }^{76}$ Cf. Arruda Alvim, Direito Processual Civil - Teoria Geral do Processo, 1972, vol. II, pp. 56, 57, 67 e 68, 107-121, 148 e 149, nota 96.

${ }^{77}$ Cf. Talamini, Coisa julgada e sua revisão, p. 81 e ss.
} 


\subsection{CONTEÚdO DA DEMANDA E OBJETO LITIGIOSO DO PROCESSO}

A demanda, por ser o ato apto a inaugurar o processo, uma vez proposta, transfere-lhe seu conteúdo, que se reflete no processo como objeto litigioso. A pretensão manifestada deverá ser aquela à qual a Jurisdição se dirige a solucionar e quanto mais pretensões e demandas apresentadas, mais amplo se torna o objeto litigioso deste processo. $^{78}$

O tema - por se relacionar ao conteúdo da tutela jurisdicional - tem repercussões em todos os quadrantes: estabilização da demanda, cumulação de pedidos, prevenção, conexão, continência, condições da ação, competência, pressupostos processuais, correlação, coisa julgada, contraditório, etc. Podemos dizer que seu nascimento deu-se com o próprio estudo do processo civil (por alguns chamado de "ciência processual").

A partir do momento em que o conteúdo da relação de direito material passou a ser aceito como algo ontologicamente distinto do conteúdo do processo (teorias autonomistas, em oposição ao imanentismo processual), especialmente a partir do estudo da pretensão, esta disciplina ganhou autonomia e passou a desenvolver suas próprias bases teóricas frente ao estudo do direito material.

Da evolução das teorias do objeto litigioso do processo, no entanto, surgiram duas formas distintas de identificá-lo. A primeira define o objeto litigioso do processo (Streitgegenstand) pelo complexo e ambíguo conceito de pretensão (Anspruch), desenvolvido especialmente na Alemanha. A segunda, principalmente na Itália, pelo desenvolvimento da teoria dos "elementos da ação" ou tria eadem, de origens romanas, mas fortemente adaptada ao direito positivo daquele país, e alterada conforme as alterações da lei apresentadas.

Nos tópicos seguintes, pretendemos descrever em linhas gerais - sem qualquer pretensão de esgotamento - as referidas teorias, com algumas de suas variações, de modo que possamos traçar uma linha comum, apta a designar o que há de essencial no conteúdo de uma demanda e quais são os elementos que devem guiar sua delimitação, a depender das circunstâncias específicas de cada direito positivo.

\footnotetext{
${ }^{78}$ É evidente que a perspectiva é tratada sob o aspecto da demanda inicial, de modo que, havendo diferentes demandas num mesmo processo, o objeto litigioso do processo deverá coincidir com a soma de todas, e não com alguma delas individualmente.
} 
O propósito, ao contrário de descrever ou exaurir a análise de teorias, é fincar bases conceituais, de modo que, posteriormente e em posse destes conceitos, sejam atingidos os melhores resultados interpretativos a respeito das técnicas processuais disponíveis em nosso ordenamento.

\subsection{TEORIA O OBJETO LITIGIOSO DO PROCESSO NA ALEMANHA E PRETENSÃO MATERIAL}

A primeira tentativa de delimitação do objeto litigioso do processo partiu do conceito de pretensão. Coube a Windscheid, em trabalho de 1856, o mérito de desenvolvêlo inicialmente sob a rubrica de Anspruch e influenciando muitos dos processualistas que o sucederam.

Para Windscheid, a pretensão deveria ser compreendida como a correspondência moderna da actio romana, diferentemente de configurar um direito subjetivo (estático) ou mesmo um poder (abstrato) de exigir a tutela jurisdicional (como ocorrerá no conceito processual de pretensão), corresponderia ao exercício de uma faculdade normativa, manifestação de uma mera vontade de seu titular, autorizada pela lei. ${ }^{79}$

\footnotetext{
79 A noção de pretensão é perigosa, pois marcada pela dualidade de sentidos (pretensão-faculdade e pretensão-ato) e pela divergência de concepções (pretensão material e pretensão processual). Grosso modo, o termo vem sendo utilizado - especialmente na doutrina alemã e italiana - tanto como faculdade (poder) de exigir o cumprimento de um direito (pretensão-faculdade), quanto como o ato, concreto, pelo qual determinado sujeito exige o cumprimento de um direito (pretensão-ato), é dizer, pretensão manifestada. Embora não identifique problemas nesta dualidade, pelo fato destas terem em comum "la concretezza della rappresentazione e l'autonomia dalla situazione materiale reale", Giuseppe Franchi afirma que o significado de pretensão seria dúplice, de modo que o mesmo termo seria utilizado para designar um ato concreto (pretensão manifestada), de pretender, bem como uma faculdade, representada pela possibilidade, ou não, de exercer tal ato. É dizer, pretensão é (i) afirmação do direito em face do obrigado, para que o reconheça, e de reflexo ao juiz, para que o declare; (ii) ou possibilidade de formular a citada afirmação do direito (mera faculdade) Cf. Giuseppe Franchi, La litispendenza, Padova: CEDAM, 1963, pp. 20-21. Essa mesma dualidade é identificada por Daniel Mitidiero: "a pretensão material pode ser encarada sob duplo prisma; precipuamente, é um estado especial do direito subjetivo: irradia do mesmo (envolve-o como película), como decorrência natural causalidade jurídica. Então, a pretensão 'não é um segundo direito, mas apenas uma nova virtualidade de que se reveste o próprio direito subjetivo', como dissera com grande precisão Ovídio Baptista da Silva. Noutro passo, pode ser encarada como uma conduta, como exteriorização da exigência, dirigida de forma individualizada a alguém". (“A pretensão de condenação", Revista de Processo n. 129, 2005, p. 52).

Dinamarco, atento para esta dualidade, refuta a noção de pretensão como faculdade, assim como a noção de pretensão de direito material. "A doutrina de raízes pandectistas emprega o vocábulo pretensão em sentido bastante diferente, para designar o direito de obter em juízo o bem devido. O apego a esse conceito, que constitui veste aparentemente moderna da vetusta actio romana (jus quod sibi debeatur in judicio persequendi), desconsidera toda a evolução por que passou o processo civil a partir do século XIX, quando se proclamou sua independência científica pelos caminhos da autonomia conceitual e da autonomia do próprio processo e da ação. Constitui incoerência afirmar a autonomia da ação, dizendo que ela não constitui inerência do direito subjetivo como antigamente se pensava e hoje todos negam peremptoriamente - mas por outro lado sustentar esse estranho conceito, que mistura, numa massa só, o direito subjetivo ao bem e o
} 
Nesta perspectiva, a ideia de pretensão não se confunde com a de direito subjetivo. Direito subjetivo seria caracterizado por um conceito estático, que representaria uma posição global de superioridade de um indivíduo sobre outro, "poder de vontade" decorrente da incidência de uma norma jurídica ao fato concreto.

O crédito seria um direito subjetivo, pois representaria um "poder" do credor face ao devedor, a norma contratual ou a norma legal, no seu âmbito estático, conferiria a aquele (credor) uma posição complexa de vantagem em face deste (devedor). A pretensão seria, por sua vez, "a exteriorização desta vontade, e, portanto, a situação do direito subjetivo no seu exercício dirigido contra outrem" (conceito dinâmico), ${ }^{80}$ exprimindo apenas uma das potencialidades dessa posição (direito subjetivo), que seria a faculdade de o credor exigir do devedor o cumprimento da prestação. ${ }^{81}$

Windscheid defende, assim, que o direito subjetivo seria algo mais amplo que a mera pretensão, ao passo que compreenderia uma "posição complexa de superioridade" do credor face ao devedor, que, ao contrário desta, não se limitaria a produzir o poder de exigir, admitindo - entre outros, mas fundamentalmente - o poder de disposição deste mesmo direito. $^{82}$

direito a obter o pronunciamento judicial a respeito da aspiração a obtê-lo. Pretensão é um estado de espírito que se exterioriza em atos de exigência, não uma situação do sujeito perante a ordem jurídica. Aquela pretensão de direito material é um conceito, além de conflitante com a moderna ciência jurídica, inteiramente dispensável no sistema: onde dizem ter pretensão ao bem, diga-se ter direito subjetivo a ele e ter condições de pleiteá-lo em juízo (pleitear não é necessariamente obter)". (Dinamarco, Instituições de direito processual civil, vol. II, pp. 102-103).

${ }^{80}$ A respeito da definição, esclarece Miguel Teixeira de Sousa: “Assim, nem a pretensão é o direito de crédito - esse é, no seu âmbito específico, um poder de vontade -, nem esse direito subjectivo é a pretensão esta é a faculdade de exigir o comportamento (activo ou omissivo) correlativo daquele direito. Nesta construção, a pretensão exprime, portanto, a efectivação de uma das potencialidades do conteúdo daquele direito subjectivo através da exteriorização subjectivamente direccionada do respectivo poder de vontade". (O concurso de títulos de aquisição da prestação..., Coimbra, Livraria Almedina, 1988, p. 22).

${ }^{81} \mathrm{Na}$ mesma linha, Allorio, embora adotando o conceito de pretensão como ato, e não como faculdade, também distingue esta de direito subjetivo. Para o processualista, o direito subjetivo é o poder ou grupo de poderes suscetível de "accertamento" autônomo, ressalvando que o "accertamento" pode ocorrer ainda que de forma extrajudicial, embora de modo mais limitado. $\mathrm{O}$ "accertamento" é a consquência da afirmação do titular, em confordância com o obrigado ou mediante um provimento do juiz; a pretensão é por isso a afirmação interessada de uma situação jurídica, destinada a obter afirmação de conformidade por parte de "estranhos qualificados". ("L'ordinamento giuridico nel prisma dell'accertamento giudiziale", Problemi di diritto, I, Milano, 1957, p. 91 e ss.).

${ }^{82}$ Mais uma vez, recorremos à lição de Miguel Teixeira de Sousa: "estritamente analisada a construção de Windscheid, não é a pretensão isolada, mas a pretensão em conjunto com o correspondente direito subjetivo, que são correlativos da situação subjectiva estatuída pelo comando legal. A pretensão é apenas a competência jurídica (rechliche Zuständigkeit) de exigir uma determinada conduta doutrem. Assim, a pretensão restringese à faculdade de exigir uma acção ou omissão, mas não é ela mesma um comportamento permitido pela ordem jurídica e reflexamente imposto ao sujeito vinculado. A pretensão é uma faculdade legal, embora não compreenda todos os poderes inerentes ao direito subjectivo (não abrange, por exemplo, o poder de disposição do direito); é somente uma expressão do exercício do direito subjetivo e, consequentemente, uma emanação da relatividade subjectiva desse direito como efeito reflexo de um imperativo legal". (O concurso de títulos de aquisição da prestação..., Coimbra, Livraria Almedina, 1988, p. 27). 
Exemplo concreto desta diferença estaria na prescrição, fenômeno que atingiria a pretensão, eliminando-a, sem contaminar o direito subjetivo, que continuaria a existir, transformando-o em "direito natural". ${ }^{83}$

A chave do pensamento de Windscheid, e a razão da diferença entre estas categorias, está no fato de que o objeto litigioso do processo seria identificado pela pretensão, e não pelo direito material/subjetivo. As referências para se individualizar um processo se encontrariam nesta pretensão manifestada subjetivamente, pelo credor em face do devedor, e não na mera posição estática e complexa de vantagem daquele sobre este (direito subjetivo). ${ }^{84}$

O conceito Windscheid é relevante na medida que o BGB (Código Civil Alemão), $\S 194$, o adotou, definindo pretensão (Anspruch) como poder jurídico de exigir uma ação ou omissão de outrem: ou como (i) faculdade ( $1^{\mathrm{a}}$ fase de seu pensamento); ou (ii) competência jurídica (segunda fase de seu pensamento, que abrange os direitos absolutos pretensões múltiplas - e direitos relativos - pretensões individualizadas).

Este pensamento, especialmente após a positivação legal, foi seguido por diferentes autores, em especial, por Friederich Lent, expoente alemão da chamada teoria

Nesse sentido, Elicio de Cresci Sobrinho aponta para o então vigente conceito de direito subjetivo: "Quando Windscheid elaborou o conceito de pretensão, a doutrina, sob influência de Hegel, concebia o direito subjetivo como dominador, o senhor da vontade; por força desse direito, na verdade 'poder' (= vontade), o indivíduo adquiriria domínio perante outros indivíduos. Pode-se, até, invocar concepção (Rosseau) somatória ou vontade geral; o direito subjetivo era entendido como manifestação, a um só tempo, poder da vontade (= Willensmacht) individual”. (Objeto litigioso no processo civil. Porto Alegre: Fabris, 2008. p. 13).

${ }^{83}$ Miguel Teixeira de Sousa aponta que, neste aspecto, a teoria de Windscheid não seguiria exatamente a mesma lógica na avaliação dos direitos reais e da sua natureza imprescritível. Afirma que somente aquelas pretensões dirigidas a um número ilimitado de pessoas são imprescritíveis. ( $O$ concurso de títulos de aquisição da prestação..., Coimbra, Livraria Almedina, 1988, p. 31-32).

A distinção entre pretensão e direito subjetivo fica evidenciada na teoria de Windscheid a respeito da prescrição. Sustenta este que a prescrição extingue a pretensão e transforma o direito subjetivo em direito natural e, desse modo, deixa claro o relacionamento entre o elemento estático (direito subjetivo) e o elemento dinâmico (pretensão). Todavia, Miguel Teixeira de Sousa aponta incoerências no pensamento de Windscheid, ao afirmar que, embora este sustente tratar exclusivamente da pretensão material, teria cunhado conceito processual de pretensão. Ao considerar as consequências do reconhecimento da prescrição, Winscheid teria afirmado esta apenas afetaria a pretensão processual, não atuando sobre a pretensão material, tendo em vista que o direito subjetivo permaneceria existente na condição de obrigação natural. $O$ concurso de títulos de aquisição da prestação..., Coimbra, Livraria Almedina, 1988, p. 31-33.

${ }^{84}$ Isso, contudo, não importa dizer que a noção de direito subjetivo e a regra de direito material seriam elementos irrelevantes na delimitação do objeto litigioso do processo. Pelo contrário. Não se pode negar que a pretensão somente pode ser concebida com referência a um direito ou relação jurídica substancial, sem a qual carece de sentido. Por se configurar como mera "competência jurídica" (rechliche Zuständigkeit) de exigir determinada conduta doutrem, a pretensão depende de uma referência (fundamentação) para ser devidamente identificada; "é somente uma expressão do exercício do direito subjetivo e, consequentemente, uma emanação da relatividade subjectiva desse direito como efeito reflexo de um imperativo legal". Cf. Miguel Teixeira de Sousa, O concurso de títulos de aquisição da prestação..., Coimbra, Livraria Almedina, 1988 , p. 22 e 27. 
substancial do objeto litigioso do processo, chamada assim por pautar-se na noção substancial de pretensão, tal qual definida acima.

Embora, como Windscheid, Lent busque conceituar a pretensão de direito material, utilizando-a como referência para a delimitação do objeto litigioso do processo, este, diferentemente, não define o objeto litigioso do processo pela simples manifestação da pretensão de direito material. Para Lent, o núcleo essencial do objeto litigioso seria constituído pela afirmação do direito (Rechtsbehauptung), direito subjetivo material, ainda que hipotético. ${ }^{85}$

É dizer, o objeto não se identificaria com a pretensão de direito material - que poderá ou não existir - mas, na verdade, estaria na afirmação de um direito ou relação jurídica in statu assertionis. ${ }^{86}$ Para Lent, não existe equivalência entre o conceito de objeto litigioso do processo e o de pretensão previsto pelo $§ 194$ do BGB, todavia, não se pode afirmar que Lent teria adotado um critério meramente processual. Isto ocorre, pois o foco de sua teoria está no direito material; "o nódulo do objeto litigioso, não é o direito material como tal, mas a afirmação de um direito ou de uma relação jurídica" ${ }^{87}$

Uma outra peculiaridade da teoria de Lent reside no fato de que, para o autor, o objeto litigioso do processo (exceto nas ações de declaração de um direito ou de uma relação jurídica) deveria ser identificado, não pela afirmação de um direito, mas pela afirmação de uma consequência jurídica. Assim, tantas fossem as consequências afirmadas na demanda tantos seriam os objetos do processo, ainda que estas pudessem ser compreendidas como decorrentes de um mesmo direito subjetivo. ${ }^{88}$

85 Elício de Cresci Sobrinho aponta que, na teoria de Lent, o objeto litigioso do processo não corresponderia à pretensão de direito material exatamente como prevista pelo $\S 194$ do BGB, de modo que para o processualista tedesco este corresponderia a uma afirmação do direito ou de uma relação jurídica in statu assertionis (cf. "De Lent a Habscheid e Jauernig", Revista brasileira de direito processual 19, p. 60). Segundo Schwab esta afirmação seria prova de que o conceito de objeto litigioso para Lent seria um conceito de natureza processual. El objeto litigioso en el proceso civil, trad. cast. Thomas A Banzhaf, Buenos Aires, EJEA, p. 14.

${ }^{86}$ Zur Lehre von Streitgegenstand, Zeitschrift für Zivilprozess, 65(1952):317, apud Cruz e Tucci, A causa pretendi no processo civil, São Paulo, RT, 2001, p, 96.

${ }^{87} \mathrm{Cf}$. Schwab, El objeto litigioso en el proceso civil, trad. cast. Thomas A Banzhaf, Buenos Aires, EJEA, p. 13.

${ }^{88}$ Pelo seu conteúdo, o conceito de objeto litigioso do processo de Lent não se apoia no direito material e, desse modo, se diferenciaria dos autores mais modernos que tratam do tema, tais quais Nikisch e Schönke. Para diferenciar a teoria de Lent da dos citados autores é necessário tomar como exemplo o caso de demanda indenizatória fundada em acidente de bonde. Para Nikisch e Schönke, ao pedir perdas e danos, o autor afirma um direito apenas, qual seja, o de receber determinada quantia em dinheiro. Lent, por outro lado, sustenta que o autor afirmaria várias pretensões processuais simultaneamente, mesmo que não precise indicá-las expressamente em sua demanda; uma decorrente do ato ilícito, uma decorrente da lei de responsabilidade civil e outra decorrente do contrato de transporte.

Schwab critica a teoria de Lent, afirmando que suas definições não são sempre uniformes, fato que seria capaz de gerar dúvidas. São duas as críticas. Lent não levaria em consideração a diferença entre consequência 
Em síntese, observamos que o conceito de pretensão substancial, compreendido como aquele que leva em consideração o direito substancial, existente ou afirmado, foi extremamente importante para o debate do objeto do processo, especialmente por força do que prescrevia do Código Civil alemão (BGB), ainda que tenham existido grandes divergências internas a este pensamento.

\subsection{A PRETENSÃO PROCESSUAL: AINDA SOBRE A PERSPECTIVA ALEMÃ}

Em sequência ao pensamento de Windscheid, e especialmente pela justificativa de que o conceito de pretensão previsto pelo BGB Alemão não seria adequado para solucionar os problemas surgidos no direito processual, foram formuladas críticas ao conceito de pretensão material que, por sua vez, permitiram o desenvolvimento de teoria antagônica, definindo o objeto do processo a partir da pretensão processual.

A primeira das críticas diz respeito à inoperabilidade do conceito de pretensão material às demandas constitutivas (positivas e negativas) e às demandas meramente declaratórias. Nas demandas condenatórias teríamos referência a uma relação de direito material, que se vincularia a uma conduta exigida de um sujeito obrigado pela norma de direito material (prestação), ou por uma pretensão absoluta (direitos reais) que encerraria uma multiplicidade ilimitada de pretensões. ${ }^{89}$

A mesma referência, todavia, estaria ausente nos demais casos. Nas demandas declaratórias negativas, nas quais a pretensão se dirige à negação da relação de direito material e, portanto, à negação à existência de uma competência jurídica (rechliche Zuständigkeit), não seria possível conceber existente uma pretensão material (ainda que simplesmente afirmada) a identificar e delimitar o objeto litigioso do processo. ${ }^{90}$

jurídica e direito material. Na sua opinião, toda consequência jurídica que se resolveria em sentença corresponderia a um determinado direito material e, nas sentenças condenatórias, a uma determinada pretensão material. Apenas na sua nova teoria Lent admite a possibilidade de um mesmo direito gerar diferentes consequencias jurídicas, de modo que, nesse caso, o objeto litigioso do processo corresponderá, não à afirmação do direito material, mas à afirmação da consequências jurídica concreta. Lent designa o objeto litigioso do processo ora como a afirmação de um direito ora como a demanda. Cf. Schwab, El objeto litigioso en el proceso civil, trad. cast. Thomas A Banzhaf, Buenos Aires, EJEA, p. 15.

${ }^{89}$ Miguel Teixeira de Sousa relata que inicialmente Windscheid não teria incluído os direitos reais na categoria das pretensões. O concurso de títulos de aquisição da prestação..., Coimbra, Livraria Almedina, 1988, p. 28-30.

90 Essa é a constatação de Maria França Gouveia, em referência às críticas de Arwed Blomeyer, Wolfgang Grunscky, Walter Habscheid e Lutz Horn a respeito da utilização da pretensão de direito material 
O mesmo ocorreria nas hipóteses de improcedência do pedido, negada a fundamentação da pretensão (direito material) não seria possível individualizar o objeto litigioso do processo por não haver um direito subjetivo a designá-lo. Ora, se o objeto do processo, de acordo com as teorias materiais, deveria estar fundado em uma pretensão material e se esta pretensão, por sua vez, seria referenciada ao direito subjetivo, como identificar um objeto quando a Jurisdição nega a existência de qualquer direito? Demanda improcedente, portanto, representaria demanda sem objeto. ${ }^{91}$

As teses materiais foram ainda criticadas pela sua inaptidão em dar soluções satisfatórias aos casos de concurso de normas materiais, nas quais o mesmo pedido é formulado com fundamento em pretensões concorrentes. Nestes casos, configurado o objeto litigioso do processo a partir da pretensão de direito material, a somatória ou o cúmulo de pretensões, ainda que diante de um único pedido, haveria por configurar a multiplicidade de objetos do processo. Transitada em julgado ação procedente com fundamento em uma das pretensões materiais, a coisa julgada material não haveria de impedir a propositura doutra demanda, fundada em pretensão concorrente.

Ante a tais constatações, foi desenvolvido um conceito distinto de pretensão, para designar especificamente o fenômeno processual, oposto ao conceito de pretensão de direito substancial, previsto pelo Código Civil Alemão (BGB). ${ }^{92}$

As teses processuais se caracterizam por diferenciar pretensão material de pretensão processual, seguindo a tendência de autonomia do direito processual face ao material, e atendendo, especificamente, às diferenças entre os termos Anspruch presentes no BGB, § 194, e na ZPO (Código de Processo Civil Alemão).

As vertentes da pretensão processual têm como pressuposto metodológico comum a teoria dualista, de separação entre os planos substanciais e processuais do ordenamento jurídico.

A ideia original remonta ao trabalho de 1885, publicado por Wach, o qual define o objeto do processo a partir de um conceito meramente processual (autônomo), representado pelo anseio do autor ou do réu à concessão da tutela jurídico-processual (pretensão processual). Pretensão não mais se daria em face do indivíduo obrigado a

como critério identificador do objeto litigioso do processo. Cf. A causa de pedir na acção declarativa, Coimbra, Almedina, 2004, p. 39.

${ }^{91}$ Cf. Miguel Teixeira de Sousa, Sobre a teoria do processo declarativo, 1980, p. 149.

92 Miguel Teixeira aponta ainda que Windscheid aduz tratar exclusivamente da pretensão material. No entanto, aponta que tal afirmação não seria complemente verdadeira, na medida em que, ao considerar as consequências do reconhecimento da prescrição, o processualista tedesco cuidaria especificamente da pretensão processual. (O concurso de títulos de aquisição da prestação..., Coimbra, Livraria Almedina, 1988, p. 33). 
cumprir a prestação (sujeito passivo da relação de direito material), mediante sua ação ou omissão, como ocorria na proposta substancial, mas agora em face do Estado. E mais, passaria a ser definida sem qualquer recurso ao direito material, partindo-se de critérios estritamente processuais.

A existência de uma pretensão voltada exclusivamente ao Estado, quanto ao fornecimento da tutela jurisdicional, foi proposta inicialmente por Hellwig, o qual difere direito de ação abstrato (direito a uma decisão sobre uma afirmação jurídica) e direito de ação concreto (direito a uma afirmação sobre um direito fundamentado). Este segundo é equivalente à ideia de pretensão de direito material. A pretensão processual, portanto, representaria a afirmação jurídica apresentada para apreciação judicial e delimitada como objeto processual. Também Windscheid concebia a actio, não como uma situação jurídica reconhecida, mas como mero "ato de pretender". ${ }^{93}$

Nas teorias dualistas, o direito concreto de ação, i.e. a pretensão de direito material, direcionada ao Estado e desprendida de qualquer direção subjetiva contra a parte privada, perde definitivamente sua relação com o objeto litigioso do processo. Nesse iter, passa a ganhar relevância a afirmação jurídica, que compõe o objeto litigioso do processo e, portanto, define a pretensão processual. ${ }^{94}$

Leo Rosemberg segue a mesma linha de raciocínio. Afasta-se do direito material e concede natureza eminentemente processual ao objeto litigioso do processo, de modo a defini-lo como o pedido destinado a obter uma declaração, suscetível da autoridade da coisa julgada. Do mesmo modo, o faz Schwab que, em importante monografia sobre o tema, aponta para a necessidade de uniformidade no conceito de objeto litigioso do processo. Este defende, ainda, um conceito meramente processual de pretensão, sustentando a inaplicabilidade do $§ 194$ do BGB ao direito processual civil. ${ }^{95}$

A despeito das relevantes contribuições de Wach, Rosemberg e Schwab, Nikisch foi o autor responsável pelo maior aprofundamento no tema, sustentando que o objeto litigioso do processo nada mais seria do que a afirmação jurídica, pela qual o autor requer a prolação de uma decisão idônea a adquirir autoridade de coisa julgada. ${ }^{96}$

${ }^{93}$ Cf. Miguel Teixeira de Sousa, O concurso de títulos de aquisição da prestação..., Coimbra, Livraria Almedina, 1988, p. 82.

${ }^{94}$ Cf. Miguel Teixeira de Sousa, $O$ concurso de títulos de aquisição da prestação..., Coimbra, Livraria Almedina, 1988, p. 83.

${ }^{95}$ Cf. Schwab, El objeto litigioso en el proceso civil, trad. cast. Thomas A Banzhaf, Buenos Aires, EJEA, p. 15.

${ }^{96}$ Cf. Maria França Gouveia, A causa de pedir na acção declarativa, Coimbra, Almedina, 2004, p. 43. 
O tema se desenvolveu, especificamente, para estabelecer critérios de identificação da demanda e do objeto litigioso do processo, especialmente nas questões relativas às teorias da individualização e da substanciação e dos problemas das chamadas ações e direitos concorrentes, cujo tratamento extrapolaria o objeto da presente tese. ${ }^{97}$ Disto, no entanto, podemos observar que o conceito de pretensão não é unívoco e representa diferentes pensamentos a respeito do objeto litigioso do processo.

Inicialmente, ainda influenciado pelo sincretismo processual, o conceito de pretensão material em Windscheid tem raízes na manifestação subjetivamente direcionada de um direito. Esta posição - ainda sob o prisma da pretensão de direito material - recebeu correções de Lent, que identifica o objeto litigioso do processo a partir do direito material, não necessariamente existente, mas afirmado pela parte.

Por outro lado, influenciados pela premissa da autonomia do processo frente ao direito material, os defensores da teoria da pretensão processual a concebem como uma manifestação de vontade direcionada ao Estado, e não à parte contrária. A depender da teoria, podemos ditar um conteúdo específico a esta pretensão, mas de uma forma geral é

${ }^{97}$ Para Nikisch, no processo de conhecimento de natureza condenatória e constitutiva, é relevante a exposição do fato constitutivo para a identificação da afirmação à pretensão ao pagamento ou à modificação jurídica. Cf. Cruz e Tucci, A causa pretendi no processo civil, São Paulo, RT, 2001, p, 98. Outro autor que analisa a questão sob o prisma do thema decidendum, Othmar Jauernig tem pertinência específica para o tratamento da questão da individualização, de modo que distingue os pedidos autodelimitados dos pedidos heterodelimitados. Para o autor, "a velha teoria da individualização e a sua réplica, a teoria da substanciação, estão ultrapassadas. Aquela reclamava, e bastava-se com a identificação técnico-jurídica da relação jurídica acionada ('arrendamento', 'empréstimo', 'propriedade', etc.), por isso punha de parte o princípio: iura novit curia. A teoria da substanciação lançava-se doutro modo para além do objectivo: pedia a formulação completa dos factos substantivada, ou seja, com todos os pormenores (vd. RGZ 143, 65). Tal formulação pode ser necessária para o êxito da ação (concludência! ....) mas não, como se disse, para a determinação do objecto do litígio". (Direito processual civil, trad. port. F. Silveira Ramos, Coimbra, Almedina, 2002, p. 206).

De modo a identificarmos como o direito alemão se distancia do direito brasileiro, Othamar Jauernig esclarece que a ZPO não admitiria a alegação de mais fatos novos em conexão com o pedido colocado, mas admitiria, num mesmo processo, a complementação da matéria de fato. O exemplo citado pelo autor é esclarecedor: "O simples completamento dos factos, no âmbito da acção instaurada é sempre admissível, não há modificação da acção (vd. Ainda o $\$ 264$ n. ${ }^{\circ}$ 1). Pelo contrário a segunda acção (com o teor do mesmo pedido) não pode apoiar-se em factos que simplesmente completam a matéria de facto do primeiro processo. Opunham-se-lhe durante o primeiro processo a excepção de litispendência, após sua conclusão a de caso julgado (BGH RR 96, 827). Exemplo de simples completamento da matéria de facto (vd. BGH RR 96, 827 NJW 85, 1560): numa acção de anulação (KO §§ 29 e segs.) alegou primeiramente o liquidatário que o falido tinha dado directamente ao réu, em agosto, 75.000 US \$, posteriormente alegou que esta quantia tinha sido canalizada para o réu lá em Julho, em duas prestações, através dum intermediário. Exemplo de alegação de factos fundada no BGH RR 87, 58. A delimitação pode ser difícil (vd. BGH RR 91, 1070)". (Direito processual civil, trad. port. F. Silveira Ramos, Coimbra, Almedina, 2002, p. 207). De forma análoga, embora aderindo à teoria da substanciação, Lent entende suficiente a afirmação do direito material deduzido para delimitar o objeto litigioso do processo nas ações atinentes aos direitos reais, não vendo relevância no título de aquisição. O contrário ocorreria nas ações obrigacionais e na ações constitutivas, nas quais teria valor a causa pretendi remota na identificação do objeto litigioso. Para Lent, a alegação dos fatos é inafastável. No que se refere, porém, às demandas declaratórias que têm por objeto direitos absolutos o autor defende que a individuação é possível mesmo sem qualquer alusão ao fato, citando o exemplo do direito de propriedade. Cf. Cruz e Tucci, A causa pretendi no processo civil, São Paulo, RT, 2001, p, 98. 
concebida como a solicitação de um pronunciamento estatal apto a tutelar a situação de direito material descrita pelo demandante.

O tema, como deixaremos mais claro adiante, longe de tratar de uma questão de "direito natural", depende umbilicalmente do direito positivo vigente, no local e no tempo da análise. Por este motivo, a breve descrição das teorias acima serve de parâmetro para que possamos identificar os problemas principais que envolvem os conceitos de que trataremos mais adiante, de demanda, pedido e pretensão, de modo que estes possam ser contextualizados e, posteriormente, definidos em conformidade com as opções de nosso direito vigente.

\subsection{TEORIA DO TRIA EADEM: OUTRA PERSPECTIVA PARA O MESMO PROBLEMA}

Por influência de um direito positivo distinto e de trabalhos acadêmicos que adotaram premissas de estudo distintas, a teoria do objeto litigioso do processo na Itália, a despeito de influenciada pelos trabalhos citados acima, "desenvolveu-se com autonomia da alemã e seguindo outros parâmetros e mentalidades diferentes". ${ }^{98}$

Os alemães adotaram como polo metodológico o objeto litigioso do processo (Streitgegenstand) e a pretensão (Anspruch), na península itálica, por outro lado, a perspectiva pautou-se no estudo da "ação" e dos elementos constitutivos da demanda (então impropriamente chamados de "elementos da ação"). Daí constatarmos com Leonel que "mesmo quando se voltam os processualistas italianos ao estudo do objeto litigioso do processo, acabam presos ao esquema da ação e de seus elementos, isto é, à teoria do tria eadem". 99

Na doutrina italiana, os registros a respeito dos três elementos são amplíssimos, de modo que sua análise profunda e detalhada fugiria ao escopo do presente trabalho. $\mathrm{O}$ fundamento das discussões se encontra nos artigos 163 e 164 do Código de Processo Civil italiano, que, ao cuidarem da citação (ato privado no processo italiano), tratam da "coisa objeto da demanda" e dos "fatos e elementos de direitos constituintes das razões da demanda", que são requisitos daquele ato e que, com referência à individualização da demanda, constituiriam o objeto litigioso do processo.

\footnotetext{
${ }^{98}$ Cf. Mariana França Gouveia, A causa de pedir na acção declarativa, 2004, p. 53.
}

${ }^{99}$ Cf. Ricardo de Barros Leonel, Causa de pedir e pedido, 2006, p. 58. 
Ocorre que, nesta questão, as incertezas e oscilações são tamanhas que muitos autores chegam a tratar do tema com imenso ceticismo, apontando, inclusive, para uma inadequação das escolhas feitas pelo direito positivo italiano, ao tentar delimitar o objeto litigioso do processo. ${ }^{100}$

Por isso, ao contrário de apreciarmos detalhadamente os contornos de cada posição, pretenderemos fornecer um panorama geral a respeito dos problemas enfrentados e das soluções propostas, na exata medida em que estas possam, posteriormente, mostrarem-se úteis aos propósitos aqui já delineados. ${ }^{101}$

\subsection{TRIA EADEM: CONSIDERAÇÕES GERAIS}

A teoria do tria eadem, pautada nos sujeitos, causa pretendi e petitum, tem o mesmo objetivo da análise das teorias pautadas no conceito de pretensão: identificar a individualidade da demanda, a partir do estudo dos elementos que compõem seu conteúdo e, por consequência, delimitar o objeto litigioso do processo.

O estudo encontra bases no direito romano, nos problemas da actio e do concursus actionarum, na elaboração da causa de pedir no direito medieval e nas sugestões do direito comum. ${ }^{102}$ Seus contornos atuais, no entanto, resultam de uma "progressiva sistematização dogmática” operada pela doutrina no século XIX a respeito, especialmente, dos limites da coisa julgada, e resumida no pensamento de Chiovenda.

Este pensamento foi desenvolvido em longo período de tempo, com início no ensaio de 1903 Identificazione delle azione e fim nas Instituzioni di diritto processuale civile, de $1928 .{ }^{103}$ Chiovenda desenvolve uma sistematização conceitual a respeito dos antigos elementos identificadores da demanda: sujeitos, petitum e causa pretendi, com a finalidade declarada, já no primeiro trabalho, de propiciar um tratamento sistemático de

100 Cf. Canova, "La domanda giudiziale ed il suo conteunto", Commentario del codice di procedura civile, pp. 8-9; e Andrioli, Lezioni di diritto processuale civile, 1, 1973, p. 253 e ss.

${ }^{101}$ Toda a polêmica reside nos últimos dois elementos citados: pedido e causa de pedir. Quanto às partes, os conceitos são bem estabelecidos e tranquilos; é conceito meramente processual e não depende de aspectos da relação material, partes são sujeitos parciais do processo, quem pede a tutela jurisdicional (demanda) e em face de quem a demanda é formulada, independentemente de serem partes legítimas ou não e independentemente de tratarmos de caso de legitimação ordinária ou extraordinária.

102 Cf. Canova, "La domanda giudiziale ed il suo conteunto", Commentario del codice di procedura civile, p. 11.

${ }^{103}$ Cf. Grasso E. "La regola della corrispondenza tra il chiesto e il pronunciato e le nulità da $<<$ ultra $>0$ da <<extrapetizione〉>, Rivista di diritto processuale, 1965, p. 387 e ss. 
temas como o conteúdo da citação, a nova demanda, a coisa julgada, a litispendência e o princípio da correlação entre pedido e sentença. ${ }^{104}$ Diz o autor: "a demanda é uma quantidade constante no processo, e a análise dos seus elementos não pode se fazer de frente a uma ou outra questão, mas de frente ao complexo das questões às quais esta dá lugar". 105

Os três elementos citados identificariam a demanda e seriam referência para estabelecer as relações entre demandas, de identidade ou semelhança, relevantes para a litispendência, conexão, continência, coisa julgada, prevenção e outros fenômenos. ${ }^{106} \mathrm{~A}$ partir destas premissas, e começando pela causa de pedir, veremos de que modo os elementos da demanda foram desenvolvidos e de que modo estes conceitos foram utilizados para a solução de problemas práticos, que exigem a devida individualização do objeto litigioso do processo.

\subsection{CAUSA DE PEDIR NA ITÁLIA: PENSAMENTO INICIAL}

O estudo da causa de pedir é apontado pela doutrina como o mais complexo dos três elementos. ${ }^{107}$ Exatamente em função dessas circunstâncias, pretendemos nos limitar a trazer um panorama geral dos debates sobre o tema, de modo a colhermos elementos úteis para as futuras conclusões deste trabalho. ${ }^{108}$

${ }^{104}$ A respeito destes elementos, manifesta-se Dinamarco: "Esses elementos são (i) o sujeito que a propõe, (ii) aquele em relação ao qual a demanda é proposta, (iii) os fatos que o autor alega para demonstrar seu alegado direito, (iv) a proposta de enquadramento desses fatos em uma categoria jurídico-material, (v) a postulação de um provimento jurisdicional de determinada natureza e (vi) a especificação do concreto bem da vida pretendido. Os dois sujeitos são partes, os fundamentos de fato e de direito são causa de pedir, a postulação do provimento jurisdicional incidente sobre o bem da vida é pedido. Partes, causa de pedir e pedido, conforme especificados de modo concreto no ato de demandar e assim lançados na petição inicial, são os elementos constitutivos de cada demanda". (Instituições de direito processual civil, 2005, vol. II, pp. 112-113).

105 Cf. Chiovenda, "Identificazione delle azione", Saggi..., 1993, p.159, trad. livre. Em sentido contrário, M. T. Zanzucchi sustentou que as questões colocadas sob o tema do objeto litigioso do processo mereceriam soluções distintas e tratamento individualizado, de modo que as noções de pedido e de causa de pedir poderiam variar nos diversos institutos considerados, em função das razões e do escopo de cada uma. (Nuove domande, nuove eccezioni e nuove prove in apello, 1916, pp. 105-106 e 330-330).

${ }^{106} \mathrm{O}$ autor assim critica aqueles que tentam fundamentar o objeto litigioso do processo apenas a partir do pedido, defendendo que a res in iudicio deducta, é dizer, o objeto litigioso do processo, seria definido tanto pelo pedido quanto pela causa de pedir. Cf. Ricardo de Barros Leonel, Causa de pedir e pedido, 2006, p. 62.

${ }^{107} \mathrm{Cf}$. Bedaque, "Os elementos objetivos da demanda à luz do contraditório", Causa de pedir e pedido no processo civil, 2002, p. 29.

108 A afirmação é de Cerino Canova, para quem não há dificuldade na identificação dos sujeitos, na medida em que os sujeitos "coincidem com os titulares da relação feita valer e o pedido consiste no tipo de 
Chiovenda conceitua causa de pedir da seguinte forma: "a causa pretendi (e debendi) é uma causa juridicamente relevante: não é um fato natural puro e simples, mas um fato, ou complexo de fatos, apto a por em movimento uma norma legal; um fato ou um complexo de fatos apto a produzir efeitos jurídicos". ${ }^{109}$

O fato ou o complexo de fatos, portanto, é a figura central do conceito chiovendiano de causa de pedir, e este deve ser um fato concreto, um acontecimento da realidade que se subsuma ao conteúdo abstrato de uma dada norma jurídica, de modo a irradiar os efeitos previstos (sanctio juris); “l'azione s'individua per il fatto e non per la norma di legge". 110

A doutrina subsequente, no entanto, criticou a posição de Chiovenda, sustentando que a indicação do "fato jurídico" como causa de pedir não teria o condão de solucionar as questões postas à análise. Com acerto, os críticos ressaltam que seria equívoca a noção de "fato jurídico", inicialmente usada por Chiovenda para indicar a causa de pedir, pois o processualista não teria precisado de que "fato" estaria falando, ou seja, seria necessária a (i) descrição pormenorizada do histórico de fatos retratado pelo autor ou bastaria a (ii) mera indicação da fattispecie legal de uma norma positiva, isto é, do "fato" individualizado pela categoria jurídica (e.g. propriedade sobre o bem X, posse sobre o bem Y, servidão sobre o bem Z, etc.). ${ }^{111}$

Em trabalho posterior, Chiovenda responde a questão. Ao tentar solucionar o problema do específico conteúdo da causa de pedir, distingue ações condenatórias fundadas em direitos obrigacionais (não absolutos) e condenatórias fundadas em direitos reais (absolutos), afirmando que, enquanto nestas bastaria a afirmação da relação jurídica

provimento solicitado e no bem jurídico pelo qual se invoca tutela". (Cerino Canova, "La domanda giudiciziale ed il suo conteunto", Commentario del codice di procedura civile, p. 16).

${ }^{109}$ Identificazione..., Saggi...p. 162-163

${ }^{110}$ E continua, afirmando que "se dunque uno stesso fatto cade sotto diverse norme, il mutamento del punto di vista giuridico, como è lecito alla parte rispetto alle sue precedenti domenda, como non escluder la eccezione di cosa giudicata, così é permesso al giudice. È anzi dovere del giudice esaminare d'ufficio la domanda sotto ogni possibile aspetto giuridico" (narra mihi factum, narro tibi ius)". (Identificazione..., in Saggi...p. 167). Canova critica a posição de Chiovenda afirmando ser equívoca a definição da causa de pedir, na medida em que esta não esclareceria se o referido "fato jurídico" seria representado $(i)$ pela descrição histórica realizada pelo autor; ou (ii) pelo antecedente da norma jurídica abstrata (fattispecie legal). Duas formas distintas de se compreender o fenômeno e com significativas repercussões para as teorias da individualização e substanciação. (Commentario del codice di procedura civile..., pp. 16-17).

111 Canova critica a posição de Chiovenda afirmando ser equívoca a definição da causa de pedir, na medida em que esta não esclareceria se o referido "fato jurídico" seria representado $(i)$ pela descrição histórica realizada pelo autor; ou (ii) pelo antecedente da norma jurídica abstrata (fattispecie legal). Duas formas distintas de se compreender o fenômeno e com significativas repercussões para as teorias da individualização e substanciação. ("La domanda giudiziale ed il suo conteunto", Commentario del codice di procedura civile, pp. 16-17). No mesmo sentido, cf. Heinitz, I limitti oggettivi della cosa giudicata, 1937, p. 148. 
(i.e. propriedade, usufruto, servidão, etc.), naquelas seria necessária a descrição da situação de fato que, em tese, daria ensejo ao nascimento da relação jurídica. ${ }^{112}$

A partir desta premissa, ficou claro que Chiovenda adotou a teoria da individualização, eis que, ao menos nos direitos absolutos, o processualista sustenta que a mera indicação de determinada "categoria de fato jurídico", aliada ao pedido e às partes, seria suficiente e adequada para identificar o objeto litigioso do processo, sem que seja necessário delimitar, detalhadamente, as circunstâncias específicas que dariam ensejo ao direito pleiteado, tal qual exigiria a teoria da substanciação.

Numa perspectiva distinta, ao invés de individualizar a causa de pedir com base no "tipo de ação", como faz Chiovenda ao tratar das ações declaratórias, constitutivas e condenatórias pautadas em direitos reais, Betti cuida do problema a partir da "razão", atribuindo relevo à categoria do direito material afirmado. ${ }^{113}$ Observa que a exposição das razões ou causa pretendi contém tudo quanto necessário para individualizar o preceito legal no caso concreto (com relação ao fato jurídico respectivo), ou seja, "a indicação de todos os elementos indispensáveis a identificar a relação (ou estado) jurídico".

Betti, nesse sentido, identifica que em relações específicas, tais quais aquelas que tratam de direitos reais, de direito familiar ou do estado das pessoas, basta a indicação da pessoa e da coisa que é objeto da demanda para individualiza-la. Noutros casos, no entanto, tais quais os que tratam das relações obrigacionais, de direito potestativo e de sucessão hereditária, seria necessária a designação do fato constitutivo, de modo que tantas seriam as relações, nesta espécie, quanto seriam os fatos constitutivos. ${ }^{114}$

O pensamento de Betti foi ainda contemplado por Heinitz, com maior profundidade, ${ }^{115}$ tendo este desenvolvido conceitos com maior relevância teórica, especialmente no tratamento dos limites objetivos da coisa julgada. ${ }^{116}$ No entanto, este

112 Chiovenda defendeu, posteriormente, a teoria da individualização, de forma muito clara. Para Chiovenda, causa de pedir, nas ações condenatórias, exigia "a afirmação da relação jurídica de que deriva o direito afirmado pelo autor em confronte com o réu". Todavia, nos direitos absolutos, bastaria a afirmação do direito, enquanto que nos direitos obrigacionais tal afirmação não bastaria. Afirma que nas ações reais a causa não é um ou outro modo de aquisição, mas o fato atual da propriedade: a questão jurídica corresponde sempre à existência do direito de propriedade. Nas ações obrigacionais afirma que são concebíveis diversas relações obrigacionais com conteúdo idêntico: de cada um deles nasce uma obrigação de prestação diferente. "Daí a necessidade de indicar também o fato constitutivo de que proveio a relação jurídica a fim de diferenciar das outras possíveis relações jurídicas de conteúdo idêntico". Cf. Instituições de direito processual civil, vol. 1, p. 351.

${ }^{113}$ Cf. Betti, Ragione e azione, in Riv. Dir. Proc. Civi., 1932, I, p. 205; e Diritto processuale civile, p. 176.

${ }^{114}$ Cf. Cruz e Tucci, A causa pretendi no processo civil, $2^{\mathrm{a}}$ ed., pp. 111-112.

${ }^{115}$ Cf. Heinitz, I limiti oggettivi..., p. 143.

116 A esse respeito, Canova afirma que o próprio Heinitz, advertido a respeito da pequena relevância prática dos conceitos que desenvolveu, voltou-se posteriormente a atender às necessidades da realidade 
também mitiga o aproveitamento da teoria da individualização, ao afirmar que o fato constitutivo deve integrar, necessariamente, a causa de pedir naqueles direitos que possam existir várias vezes sobre a mesma coisa, assim como o fez Betti. ${ }^{117}$

$\mathrm{O}$ primeiro jurista, no entanto, a apresentar críticas sistematizadas à teoria da individualização e a verdadeiramente responder Chiovenda foi Zanzucchi. Ao contrário daquele, Zanzucchi opunha-se à unificação do tema do objeto litigioso do processo, negando a possibilidade de tratamento uniforme de uma gama de situações que julgava essencialmente heterogêneas, i.e. litispendência, conexão, continência, coisa julgada, correlação e estabilização.

Zanzucchi sustentou que não seria adequada a distinção entre direitos reais e direitos obrigacionais quanto à causa de pedir, de modo que em ambos os casos seria necessária a enunciação do fato concreto para distinguir uma demanda doutra, não sendo possível individualizar a demanda sem o recurso aos fatos constitutivos do direito pleiteado.

O processualista critica a individualização, mesmo nos casos de direitos absolutos (autodeterminados), apontando para a possibilidade de o mesmo direito (i.e. categoria jurídica) ter fundamento em duas ou mais circunstâncias fáticas distintas entre os mesmos sujeitos. Cita o exemplo de o mesmo bem móvel ser objeto de dois depósitos distintos entre as mesmas partes, hipótese na qual, havendo demanda em relação ao primeiro depósito e demanda em relação ao segundo depósito, somente seria possível distingui-las com base nos fatos concretos, já que estaríamos diante dos mesmos sujeitos, do mesmo bem e da mesma situação-tipo de direito material.

Por este motivo, Zanzucchi esclarece que não basta - em nenhum dos casos, direitos reais ou obrigacionais - indicar o "direito" e a sua natureza, mas é "necessário relevar o fato pelo qual o direito afeta determinada pessoa, e não o fato em abstrato (depósito, compra e venda etc.), mas em concreto (tal depósito, tal compra e venda, etc.)". 118

aplicativa. ("La domanda giudiziale ed il suo conteunto", Commentario del codice di procedura civile, p. 24). A respeito ainda do pensamento de Heinitz, cf. Botelho de Mesquita, "A causa pretendi nas ações reinvindicatórias, Revista de direito processual civil, n. 6, 1967, pp. 188-9.

${ }^{117}$ Cf. Heinitz, Ilimiti oggettivi..., p. 194.

${ }^{118}$ Cf. Zanzucchi, Nuove domande..., p. 336-337. 
Bellavitis, na mesma linha, fomenta forte crítica a Chiovenda, apontando contradições em seu pensamento. ${ }^{119}$ Sustenta que o vinculum iuris não se transformaria em causa de pedir, afirmando que a identificação da relação jurídica deve considerar dois elementos: “objetivação da norma jurídica e subjetivação da norma jurídica: isto é desenvolvimento dos fatos e justaposição da norma, até a posição recíproca de objeto (prestação) e sujeitos". ${ }^{120}$

Defende, assim, que seria logicamente inconcebível o argumento desenvolvido por aqueles que defendem a individualização, de modo que a norma não poderia ser isolada e considerada como elemento em si mesmo, mas tão somente poderia ser concebida em relação aos outros dois elementos (objeto e sujeitos); "somente como a relação de fato deve ser sempre considerada, mas não pode ser considerada, salvo se em relação à norma". ${ }^{121}$ Bellavitis entende que o objeto ou a causa de pedir não podem por si só estabelecer "o valor da demanda", o valor resultaria da combinação entre esses dois elementos; a causa de pedir é o fato do qual o objeto seria - segundo alegações do demandante - a reintegração jurídica. ${ }^{122}$

A polêmica entre individualização e substanciação, portanto, já no início do século XX, mostrava-se em praticamente todas as suas feições, a denotar as grandes dificuldades encontradas pelos processualistas na identificação do que seria essencial para individualizar uma demanda e um processo, diferenciando-os dos demais.

\footnotetext{
119 Bellavittis critica Chiovenda ao afirmar que este define a causa de pedir como "causa juridicamente relevante" e depois nas paginas seguintes afirma que a ação se individualiza pelo fato e não pelo direito (norma de lei). Cf. L'indentificazione delle azione, 1924, p. 98.

${ }^{120}$ Bellavitis, M. L'indentificazione delle azione, 1924, p. 98.

${ }^{121}$ Bellavitis, M. L'indentificazione delle azione, 1924, p.101.

${ }^{122}$ Assim são suas palavras: "come la causa pretendi sarà un fatto giuridicamente rilevante solo se sai tale in relazione all'oggetto domandato, così l'oggetto sarà rispondente al diritto e la domanda fondata in merito, solo se la fattispecie dedotta nella cusa pretendi autorizzi quel provvedimento, mentre nel caso contrario potrà o no dar luogo all'azione secondo che in sè, o per sè, offra al giudice la possibilità della atribuizione positiva o negativa di un diritto subbietivo". (Bellavitis, M. L'indentificazione delle azione, 1924, p. 104). Outro que sustenta a substanciação é Gianozzi, pelo qual o objeto litigioso do processo seria delimitado pelo fato constitutivo do direito controvertido (causa de pedir) e pelo petitum, de modo que aquele, ao lado das partes, seriam essenciais para a identificação da demanda. Cf. La modificazione della domanda nel processo civile, pp. 51-52
} 


\subsection{CAUSA DE PEDIR NA ITÁLIA: PÓS 1942}

Após os debates mencionados acima, a polêmica quanto à definição do objeto litigioso do processo ganha nova força com a introdução do Código de Processo Civil italiano de 1942, e especialmente com a reforma de 1950, que flexibilizou o regime de preclusões original daquele Código, e permitiu a reformulação do petitum e da causa pretendi.

De fato, a doutrina passa a sustentar que, à luz do Código, a alteração do pedido e da causa de pedir não teria, efetivamente, o condão de alterar o conteúdo da demanda. ${ }^{123}$ Satta e Liebman, na mesma linha e seguindo de certa forma o que já havia sido defendido por Chiovenda, argumentam que enquanto nas demandas obrigacionais o título jurídico (fato do qual surge o direito) é relevante para individualizar a demanda, nenhuma importância ostentaria nas demandas declaratórias e nas condenatórias fundadas em direitos absolutos:

\footnotetext{
"Nas demandas declaratórias e condenatórias fundadas em direitos absolutos, Satta e Liebman defendem que não seria necessária a identificação do fato constitutivo (i.e. como foi adquirida a propriedade, por doação, compra e venda, usucapião, etc.), bastando "indicar o direito que se afirma existente (propriedade, servidão, etc.)", isto porque uma vez que tal direito permaneceria sempre o mesmo, "qualquer que seja o fato constitutivo em particular que caso a caso seja invocado: a propriedade de um bem é sempre o mesmo direito, tenha ela sido adquirida por herança, compra e venda ou usucapião. Por isso, não muda a causa pretendi pelos simples fato de haver referência a um ou a outro dos possíveis títulos de aquisição". ${ }^{124}$
}

Corrado Ferri acrescenta seu pensamento à polêmica, relatando especificamente que as demandas fundadas em direitos absolutos seriam individualizadas apenas pelo pedido, sem a necessidade de indicação de causa de pedir, tendo em vista que estas dependeriam apenas da indicação do "título de aquisição originária", que representaria o próprio direito deduzido, sem a narrativa dos fatos. ${ }^{125}$

De uma forma geral, fixada a polêmica, as posições adotadas quanto à individualização podem ser resumidas em três, como o fez Cerino Canova: (i) a

\footnotetext{
${ }^{123}$ Cf. Costa, "Domanda giudiziale", Novissimo digesto italiano, v.6, 1957, p. 167-168.

${ }^{124}$ Cf. Satta, "Domanda giudiziale", Enciclipedia del diritto, v. 13, p. 824-825; e Liebman, Manual de direito processual civil, v. 1, 1985, p. 194-5.

${ }^{125}$ Cf. Ferri, Struttura del processo e modificazione della domanda, Padova: Cedam, 1975, p. 161-162.
} 
individualização pelo sujeito; (ii) individualização pelo conteúdo; e (iii) individualização pelo fato constitutivo.

As demandas passíveis de identificação pelo sujeito e pelo conteúdo seriam fundadas em direitos autodeterminados, na medida em que seriam identificadas pelo próprio direito, e não pelo título de aquisição, contemplando em si todos os possíveis títulos de aquisição referentes aquele direito alegado; "a individualização do direito, e da demanda, através do conteúdo e dos sujeitos, justifica-se precisamente pela unicidade e irrepetibilidade da mesma situação substancial". ${ }^{126}$

Os chamados direitos autodeterminados não se limitariam ao direito de propriedade, abarcando também outros direitos reais, direitos de personalidade e aqueles que se relacionam ao status de família, que possuem tratamento processual idêntico ao direito de propriedade. Assim, uma ação de depósito, uma ação possessória, uma declaratória de paternidade, etc. seriam identificadas pelo mero apontamento do direito de propriedade, pela posse, pela relação de paternidade, etc., que, em tese, tratando daqueles mesmos indivíduos, seriam apenas um.

Diferentemente, as demandas pautadas em direitos heterodeterminados não poderiam ser individualizadas pelos seus sujeitos e pela situação de direito material (elementos estruturais). Enquanto nas demandas fundadas em direitos autodeterminados toda a relevância para a individualização se encontraria no pedido, nas demandas fundadas em direitos heterodeterminados a causa de pedir (fática) passaria a assumir maior repercussão, na medida em que a descrição dos fatos específicos geradores do direito passariam a ser fundamentais. ${ }^{127}$

Estas foram as premissas que resumiram os pensamentos vigentes no período, especialmente depois das críticas à teoria da substanciação, impondo limites à sua aplicabilidade e, especialmente, ressaltando a importância dos fatos concretos na delimitação da causa de pedir. Dito isso, passemos a analisar criticamente estas proposições.

\footnotetext{
${ }^{126}$ Cf. Canova, "La domanda giudiziale ed il suo conteunto", Commentario del codice di procedura civile, p. 177.

${ }^{127}$ Essa é a observação de Cristanto Mandrioli, cf. "Riflessioni in tema di petitum e di causa pretendi, Rivista di diritto processuale, 1984, n. 3, p. 476.
} 


\subsection{CRÍTICAS ÀS TEORIAS DA INDIVIDUALIZAÇÃO E SUBSTANCIAÇÃO}

Como ocorrido em outros âmbitos do processo civil, as discussões relativas às teorias da individualização e da substanciação adquiriram tal grau de complexidade que, de certo modo, se desgarraram das questões práticas que pretendiam inicialmente solucionar.

A polêmica não apresentou resultados satisfatórios, seja pela nebulosidade ou pela incerteza presentes na teoria da substanciação, que não logrou êxito em definir os critérios para delimitar os fatos concretos que integrariam necessariamente a causa de pedir, seja pela abstração da teoria da individualização, que eliminou a referência à causa de pedir e tentou inserir no pedido todo o objeto litigioso do processo, algo que se mostrou de todo intangível. ${ }^{128}$

Proto Pisani, atentando para essa situação, afirma que das duas teorias se poderia concluir a necessidade tanto de uma referência fática quando de uma referência normativa para individualizar-se a demanda, propondo que as discussões fossem mitigadas a partir da noção de fattispecie. ${ }^{129}$ Para o processualista, o problema principal se colocaria diante da própria abstração do processo de conhecimento, que admitiria a veiculação de toda e qualquer causa de pedir imaginável, na medida em que toda e qualquer pretensão poderia nele ser veiculada, sem quaisquer restrições (princípio da universalidade da tutela jurisdicional).

Sua proposta, com efeito, seria no sentido de que a causa de pedir abrangeria as circunstâncias de fato circunscritas pela fattispecie da qual derivaria o direito deduzido em juízo, por meio do petitum. Assim, se os fatos alegados importarem na extrapolação daquela fattispecie invocada ou exigirem a invocação de outra fattispecie, estaríamos diante de uma demanda distinta, e complementa:

\footnotetext{
“não haverá, por outro lado, modificação da causa pretendi quando se alterarem os elementos de fato dos quais derivam os elementos de direito da fattispecie constitutiva do direito deduzido em juízo, tampouco quando se alterarem os fatos não coligados com o direito deduzido, isto é, dos fatos não inseridos no âmbito de sua fattispecie constitutiva". ${ }^{130}$
}

\footnotetext{
128 A este respeito, cf. Gian Franco Ricci, "Individuazione o sostanziazione nella riforma del processo civile”, Rivista Trimestrale di diritto e procedura civile, 1995, n. 4, p. 1.235, nota 12.

${ }^{129}$ Proto Pisani, Lezioni di diritto processuale civile, $5^{\mathrm{a}}$ ed., p. 57.

${ }^{130}$ Cf. Cruz e Tucci, A causa pretendi no processo civil, $2^{\mathrm{a}}$ ed., pp. 123.
} 
Perspectiva similar foi adotada por Fazzalari, o qual teria sido o percussor da afirmação pela qual ambas as teorias (individualização e substanciação) teriam efeitos práticos muito similares. Também para este processualista, "alegação do fato constitutivo" (teria da substanciação) ou "afirmação da relação jurídica" (teoria da individualização) representariam dois lados de uma mesma moeda: a fattispecie normativa. ${ }^{131}$

Para Fazzalari a causa de pedir seria estabelecida a partir de uma correlação entre a "situação substancial", deduzida pelo demandante in statu assertionis, e o processo, situação esta que se manifestaria de modo diferenciado; "na petição inicial da ação de conhecimento, por exemplo, exsurge como afirmação do autor, transforma-se, em seguida, em objeto das alegações, das provas e do debate, ou seja, do contraditório", por fim, após a instrução, transforma-se na situação negada ou reconhecida pelo órgão jurisdicional, objeto do provimento. ${ }^{132}$

O processualista, na verdade, realça a necessária relação entre direito e processo que se apresentaria na causa de pedir. É evidente, no entanto, que tendo em vista a autonomia do processo frente ao direito material, este conteúdo substancial somente poderia ser analisado em estado de asserção, é dizer, trata-se, não de um direito efetivo e existente, mas da alegação de um direito, possivelmente existente. ${ }^{133}$

O processualista enxerga um caminho lógico que se inicia pela lesão ou ameaça de lesão a direito que, por sua vez, torna necessária a tutela e que, não concedida espontaneamente, torna necessária exigi-la do Estado-juiz, por meio da demanda. ${ }^{134} \mathrm{~A}$ partir destas premissas, pretende desapego à polêmica da individualização/substanciação, buscando na estrutura da norma jurídica e na eficácia pretendida com o processo a identificação do objeto litigioso. A esta perspectiva retornaremos adiante.

\subsection{ESPECIFICAMENTE SOBRE O PEDIDO}

A teoria a explicar o objeto litigioso do processo deveria ser muito clara: a causa de pedir representa os motivos que levam as partes a litigar (porque se pede); e o pedido,

\footnotetext{
${ }^{131}$ Cf. Fazzallari, Instituzioni di diritto processuale, p. 233-4.

${ }^{132}$ Cf. Cruz e Tucci, A causa pretendi no processo civil, $2^{\mathrm{a}}$ ed., pp. 127-128.

133 Esta premissa, com efeito, permite que o processualista apresente uma proposta diferente para a individualização do objeto litigioso do processo, que será melhor explicitada adiante.

${ }^{134}$ Cf. Fazzallari, Instituzioni di diritto processuale, p. 233-4.
} 
aquilo pelo que se litiga (o que se pede), um conceito a depender do outro. ${ }^{135}$ No entanto, se há graves problemas na delimitação da causa de pedir, como já visto, também os há na delimitação do pedido.

A primeira destas questões diz respeito à divisão do pedido entre pedido mediato e pedido imediato, conforme proposto por Chiovenda. Pedido imediato é a solicitação da parte em referência à técnica processual, isto é, à natureza do provimento jurisdicional a ser formulado, variando conforme a natureza da crise de direito material. Assim temos, no processo de conhecimento, um pedido imediato de natureza condenatória, constitutiva ou declaratória. A noção de pedido mediato, no entanto, é bem mais problemática, e foi definida por Chiovenda pela expressão bem da vida (bene giuridico), de conteúdo absolutamente incerto e impreciso.

Canova, nesse sentido, critica Chiovenda ao afirmar que a utilização do conceito de bene giuridico foi um momento de "menor precisão definitória" em sua teoria, de modo que o Mestre teria demonstrado uma mera tendência, mas não teria logrado êxito em determinar um efetivo conceito. ${ }^{136}$

E a doutrina até a presente data não teve condições de assentar, exatamente, do que trataria a expressão, de modo que há duas posições em geral a defini-la. A primeira conceitua o bem da vida como "o direito pelo qual se pede tutela". A segunda, por sua vez, define-o como a "coisa material objeto do litígio".

Seguindo a primeira linha, temos a posição de Franchi pelo qual o pedido mediato representaria "o efeito jurídico" que com a demanda "se propõe a obter, identificado com relação à realidade extraprocessual sobre a qual a decisão é destinada a incidir". ${ }^{137}$ Proto Pisani, em sentido similar, define-o como o "objeto substancial ou de mérito", que representaria o concreto direito substancial deduzido pelo autor na demanda, ${ }^{138}$ razão pela qual sustenta que, melhor do que distinguir entre pedido mediato e pedido imediato, seria falar em objeto substancial e em objeto processual do processo. ${ }^{139}$

\footnotetext{
${ }^{135}$ Chiovenda descreve pedido e causa de pedir como entidades distintas, nos seus Principii (p. 280) $e$ Identificazione (pp. 162-163). No entanto, em suas Instituzioni - último trabalho a tratar do tema Chiovenda trata do pedido e da causa de pedir em uma pespectiva unitária, no qual esta exerceria um papel instrumental em relação aquele. Canova, "La domanda giudiziale ed il suo conteunto", Commentario del codice di procedura civile, p. 16.

${ }^{136}$ Cerino Canova, "La domanda giudiziale ed il suo conteunto", Commentario del codice di procedura civile, p. 34.

${ }^{137}$ Cf. Franchi, La litispendenza..., p. 88-91.

138 Cf. Ferri, Struttura del processo, p. 88; giannozzi, p. 15 e 112 e 62 e 99 - conceitos distintos e imprecisos; Segni - Costa; Lugo, Manuale, p. 46.

${ }^{139}$ Cf. Proto Pisani, Lezioni di diritto processuale civile, $5^{\mathrm{a}}$ ed., p. 57.
} 
Seguindo a segunda linha, por sua vez, destaca-se a posição de Liebman, pela qual o pedido mediato representaria o bem jurídico ao qual o provimento (representativo do pedido imediato) se referiria, ${ }^{140}$ conceito que indica a coisa (jurídica e economicamente relevante) ao qual o provimento jurisdicional se direciona, posição esta acompanhada por outra parte da doutrina italiana. ${ }^{141}$

Para os fins do presente trabalho, adotaremos o conceito de Proto Pisani, que diferencia os pedidos entre objeto processual, que diz respeito à técnica, e objeto material, que diz respeito ao efeito jurídico, com aptidão de transformação da realidade física, a ser obtido por meio do processo. A este ponto também retornaremos mais adiante.

\subsection{PARTES}

O conceito de partes não apresenta grandes dificuldades, não sendo assunto de polêmicas ou debates relevantes, ao contrário do que ocorre em relação à causa de pedir e ao pedido. Não obstante isso, é conceito fundamental, na medida em que permite a identificação dos indivíduos (i) que se sujeitarão ao contraditório e que, por consequência, (ii) deverão ser afetados pelo resultado do processo e, quando pertinente, pela (iii) coisa julgada material.

O conceito de partes nasce em Chiovenda como um conceito meramente processual: parte é quem formula o pedido de tutela jurisdicional e em face de quem tal pedido é formulado, seja no processo de conhecimento, no processo de execução, no processo cautelar ou em qualquer outra técnica processual.

Cuida dos sujeitos parciais da relação jurídica processual, que de algum modo integraram-se ao processo, ainda que de forma equivocada, e que têm interesse privado na causa, ainda que esse interesse se limite à declaração de sua própria ilegitimidade.

\footnotetext{
${ }^{140}$ Cf. Liebman, Manuale di diritto processuale civile, $5^{\mathrm{a}}$ ed., 1992, pp. 186.

${ }^{141}$ Cf. Andrioli, Lezioni..., p. 252; Mandrioli, Corso..., i, p. 127; Zanzucchi, Diritto processuale civile, vol. II, 1962, p. 7. Calamandrei aparentemente se utiliza de critério distinto, ao definir o objeto mediato como o bem que satisfaz o interesse representado pela tutela dirigida ao estado, mas exige também a indicação do direito subjetivo inadimplido. ao fazê-lo, o autor sublinha a relação entre pedido e causa de pedir (instituzioni, i, pp. 137-138). Outra posição que merece referência é a de Pugliese, pelo qual o pedido mediato seria: "a afirmação em juízo da situação favorável (direito subjetivo, poder, status, etc.) que o sujeito pressupõe atribuída a si pelo ordenamento". (Giudicato civile (diritto vigente), in enciclopedia del diritto, xviii, milano, 1969, p. 863). Criticando Pugliese, cf. Ferri, Profili..., p. 85 e Struttura del processo..., p. 89. De Stefano G., por sua vez, parece somar as duas posições, afirmando ser o objeto mediato tanto o bem quanto o efeito jurídico. (“Azione civile”, in Novíssimo digesto italiano, II, Torino, 1957-1958, p. 52).
} 
Esta constatação é importante para a delimitação do objeto litigioso do processo, especialmente nos casos de legitimação ordinária, em que sendo as partes $\mathrm{X}^{1}$ e $\mathrm{X}^{2}$ ou $\mathrm{X}^{1} \mathrm{e}$ $\mathrm{X}^{3}$, teremos um objeto litigioso do processo completamente distinto, ainda que os demais elementos da demanda restem absolutamente inalterados.

Não importando a teoria que se adote, a parte é sempre elemento relevante na individualização da demanda. Adotando-se a teoria da individualização ou a teoria da substanciação, a parte, ou junto apenas com o pedido ou junto com o pedido e a causa de pedir, sempre será utilizada como referência para a individualização da demanda. Exceção feita apenas aos casos de legitimação extraordinária.

Caso entendamos que a causa de pedir pressupõe apenas a alegação de um direito ou situação jurídica, tal qual a posse, a servidão ou a propriedade, este direito estará bem individualizado mediante sua contextualização a determinados sujeitos, sem os quais deixa de ter qualquer referência concreta. Do mesmo modo, se se admite que a causa de pedir depende da narrativa dos fatos concretos, é essencial que estes fatos tenham referência a determinados indivíduos que, uma vez presentes na relação jurídica afirmada na demanda, deverão estar também presentes na relação processual.

E mais, não havendo esta pertinência subjetiva entre causa de pedir e partes, estaremos diante do fenômeno da ilegitimidade processual, que deverá acarretar ou a extinção do processo ou a exclusão da parte daquela específica relação jurídica processual.

\subsection{DIFERENTES TEORIAS: PONTOS COMUNS}

Quando observamos a tentativa de definição do objeto litigioso do processo a partir da ideia de pretensão, vemos que esta não é unívoca. Em primeiro lugar, designa dois fenômenos complemente distintos: (i) a pretensão de direito material, dirigida contra o sujeito passivo da relação de direito material (devedor) e vinculada ao direito subjetivo, embora não se confunda com este (Windscheid), e (ii) a pretensão processual, que seria de natureza autônoma, existiria independentemente do direito material, e seria dirigida contra o Estado, não contra o particular (Wach).

Não fosse isso suficiente, o termo também é ambíguo, eis que designa tanto $(i)$ o poder ou a faculdade jurídica de se exigir o cumprimento de uma prestação, quanto (ii) o 
ato de exercício desse direito, a declaração de vontade de que determinada prestação seja comprida, num caso concreto.

Em função dessa multiplicidade de sentidos, não é possível fazer qualquer comparação significativa entre pretensão e Streitgegenstand e teoria do tria eadem. Até porque, também esta teoria goza de alto grau de incerteza, especialmente na delimitação do que é pedido e do que é causa de pedir.

Grosso modo, pretensão se relacionaria diretamente com pedido e, apenas de forma reflexa, com os demais elementos da demanda, dado que estes servem para identificar a natureza e a extensão do pedido, e especialmente de acordo com as premissas dos autores que entendem relevante a causa de pedir para tanto. Mas qual "pretensão" seria essa e qual "pedido" seria esse?

A pretensão de direito material, a despeito de representar um conceito útil, especialmente para justificar os poderes que o sujeito ativo da relação de direito material adquire para a satisfação de seus interesses extrajudicialmente, não tem repercussões relevantes para o processo, apenas para o direito material. Tanto isso é verdadeiro, que o reconhecimento da inexistência da pretensão, pela verificação da prescrição, é circunstância que gera a extinção do processo, com julgamento de mérito, ao contrário de uma sentença terminativa.

A pretensão processual, por sua vez, é um conceito com relevância específica para o processo. A pretensão-faculdade, no seu aspecto processual, confunde-se com a própria garantia moderna de direito de ação: poder de pleitear um pronunciamento judicial frente ao Estado de forma incondicional, é dizer, sem nenhuma referência prévia ao direito material. Tal conceito, pela sua abstração, é relevante do ponto de vista constitucional, mas não para a identificação de uma demanda em concreto ou para delimitação do objeto litigioso do processo.

Em nosso sistema vigente, à luz da inafastabilidade e universalidade da tutela jurisdicional, é antes uma garantia incondicionada do jurisdicionado, sem conteúdo concreto e, portanto, sem elementos aptos a identificar ou individualizar uma dada pretensão, diferindo-a das demais.

Resta-nos apenas o conceito processual de pretensão-ato. A despeito de algumas variações dentro da teoria, podemos tomá-la como: afirmação jurídica, pela qual o autor requer a prolação de uma decisão judicial, apta a conceder uma determinada tutela jurisdicional. A pretensão é composta exatamente pelo pedido imediato (relacionado à técnica processual), pois é um pedido de um pronunciamento do Estado, e ao pedido 
mediato (bem da vida), pois tem por objetivo a proteção de uma situação jurídica afirmada pelo demandante.

O nexo entre pretensão e pedido, no entanto, não seria suficiente para identificar e individualizar o objeto litigioso do processo. Isto ocorre, porque a afirmativa do direito (situação substancial), com o respectivo apontamento dos sujeitos nele envolvidos, é pressuposta à pretensão processual. Somente a partir destes elementos uma pretensão se individualiza, é dizer, apenas em referência a uma hipótese de direito material com indicativo de seus respectivos sujeitos (fato que se submete a uma norma ou apenas um "direito" - substanciação ou individualização) uma pretensão poderia ser devidamente identificada. ${ }^{142}$

O mesmo, com efeito, ocorre com a teoria do tria eadem, que identifica o objeto litigioso do processo no pedido, mas reconhece que este somente pode ser compreendido a partir das partes e da causa de pedir. ${ }^{143} \mathrm{Ou}$, na visão de Fazzallari e Proto Pisani, a partir da descrição em estado de asserção dos fatos que, uma vez passíveis de submissão a determinada fattispecie abstrata, seriam aptos a produzirem os efeitos jurídicos pretendidos pelo agentes.

Nessa medida, a despeito das variantes de sentidos e das diferentes concepções a respeito dos elementos essenciais das teorias tratadas, há sim pontos em comum entre a teoria da pretensão e a teoria do tria eadem, eis que é possível afirmar que o conceito de pretensão-ato processual se identifica com o conceito de pedido, tanto no seu aspecto imediato, quando no seu aspecto mediato, dado que ambos pressupõem a indicação de uma causa e de sujeitos para a sua identificação (em estado assertivo) e que ambos representam um ato de vontade, manifestado frente ao Estado, no sentido de que seja emitido um pronunciamento judicial (pedido imediato) apto da proteger determinada situação de direito material afirmada (pedido mediato). ${ }^{144}$

\footnotetext{
${ }^{142}$ Assim é a lição de Dinamarco: "O ato de vir ao juiz pedindo tutela jurisdicional, chamado demanda, tem por conteúdo uma pretensão de quem o realiza. Pretensão é a exigência de subordinação de um interesse alheio ao interesse próprio. É um fato, não uma relação ou situação jurídica (Carnelutti). O sujeito que aspira a um bem, não o obtendo por outro meio, externa sua aspiração apresentando-a ao Estado-juiz; e esse é o único meio civilizado que existe para obtê-lo sem o concurso da vontade do outro sujeito envolvido. Ou porque a pessoa que poderia dar-lhe o bem a que ele aspira não lhe dá, ou porque a lei impede que dê (supra, n. 1), sem o concurso do sistema jurisdicional aquele que o pretende ficaria definitivamente sem ele. A exigência, que caracteriza a pretensão, expressa-se mediante os atos com que o sujeito cria condições para que sua vontade se imponha e ele acabe por haver o bem a que aspira. Demandar em juízo é portanto um modo de exigir". (Instituições de direito processual civil, vol. II, p. 102).

${ }^{143}$ Cf. Schwab, El objeto litigioso en el proceso civil, p. 241.

144 Chiovenda descreve os sujeitos, o pedido e a causa de pedir como entidades distintas na "Identificazione" e nos "Principii", mas nas Instituições o Mestre acentua o papel o objeto litigioso do
} 
A pretensão é introduzida no processo com a demanda, e aguarda análise até o momento em que é obtido provimento de mérito. Este, por sua vez, "satisfaz a exigência de uma resposta contida na pretensão com a declaração positiva ou negativa do direito contestado ou mesmo controverso". O processo, portanto, atua de modo a substituir a afirmação privada das partes, mera proposta de solução do conflito elaborada na demanda, com um ato de poder, oficial, apto pacificar e solucionar o conflito. ${ }^{145}$

O presente trabalho, como efeito, tomará como premissa a pretensão processual (pedido mediato), devidamente identificada pelas partes e pela causa de pedir remota ativa (fatos essenciais), como o exato conteúdo da demanda que, uma vez proposta e às vezes somada a outras demandas, formará o objeto litigioso de um processo (mérito). No capítulo seguinte, verificaremos de que modo isso ocorre.

processo, ou melhor, do bem jurídico controverso e, desse modo, cuida em uma perspectiva unitária pedido e causa de pedir. Nesta identifica um papel fundamental na identificação daquele.

${ }^{145}$ Giuseppe Franchi, La litispendenza, 1963, p. 24. 


\section{INDIVIDUALIZAÇÃO DA DEMANDA}

\subsection{QUE SIGNIFICA INDIVIDUALIZAR UMA DEMANDA?}

Nos capítulos anteriores, propusemos um conceito de demanda e chegamos à conclusão de que uma demanda apenas pode ser individualizada a partir de seu conteúdo (Capítulo 1) e investigamos diferentes teorias, desenvolvidas ao longo da história, com a finalidade de delimitar este conteúdo específico (Capítulo 2). No presente capítulo, partindo das premissas já expostas, pretendemos estabelecer critérios para a delimitação deste conteúdo à luz do direito positivo brasileiro.

Vimos que o pedido, a causa de pedir e as partes são os critérios pertinentes para tanto, mas de que modo poderemos identificar estes elementos e quando cada um deles será, ou não, relevante para o juízo individualização? Toda a narrativa de fatos é causa de pedir? Como separar os fatos principais dos fatos secundários? A fundamentação jurídica da demanda (causa de pedir próxima) é relevante? A causa de pedir passiva é relevante? Todo o pedido serve para individualizar uma demanda? De que modo as partes podem influenciar este juízo de individualização?

A estas perguntas pretendemos responder estabelecendo critérios para a interpretação da demanda e para a individualização de seu conteúdo e, por consequência, do objeto litigioso do processo.

\subsection{QUE É PEDIDO?}

Para significativa parte da doutrina nacional a seguinte definição de pedido seria a referência: "conteúdo da demanda, a pretensão processual, o objeto litigioso do processo, o mérito da causa" (...) é o anseio, a aspiração do demandante, de que para aquela parcela da 
realidade social por ele trazida na demanda e que lhe está sendo prejudicial, seja dada a solução conforme ao direito segundo o seu modo de entender". ${ }^{4}$

Há nesta tentativa definitória menção a institutos jurídicos dos mais variados, relacionando-o com (i) conteúdo da demanda; (ii) pretensão processual; (iii) objeto litigioso do processo; e (iv) mérito. No entanto, o pedido - embora conexo a estes conceitos - não se identifica com eles.

Pedido não é conteúdo da demanda, pois vimos que conteúdo é o sentido que se extrai do ato processual, subtraído dele toda sua forma. Não podemos negar que o pedido tem um conteúdo, que integra o conteúdo da demanda e que serve como elemento para identificação da vontade do demandante, mas não é sua totalidade, conforme veremos a seguir.

Do mesmo modo, não podemos afirmar que pedido e pretensão processual são conceitos sinônimos. Em primeiro lugar, porque "pretensão processual" já é um conceito ambíguo, significando tanto a possibilidade de se exigir do Estado o cumprimento de um direito (pretensão-faculdade) quanto o ato, a manifestação de vontade para que um direito seja cumprido (pretensão-ato). Em segundo lugar, pois, ainda que adotássemos apenas o segundo conceito (pretensão-ato), que mais se aproxima da noção de pedido, não nos referiríamos a todos os aspectos deste fenômeno, na melhor das hipóteses, a pretensão representaria apenas parte do conteúdo do pedido (pedido mediato) que, como veremos, depende sempre de uma referência à causa de pedir para fazer algum sentido.

Por fim, também seria incorreto afirmar que pedido é o objeto litigioso do processo ou é o mérito. E isto porque, sabemos que tanto o objeto litigioso do processo quanto o mérito são o conteúdo - delimitado pela demanda (inicial ou inicial + ulterior) que deverá ser objeto da apreciação jurisdicional.

O conteúdo do mérito e do objeto litigioso do processo é delimitado pelas partes, pela causa de pedir e pelo pedido, e não poderia se restringir a este último. A este respeito, Nelson Nery Jr. fala em pedido em sentido lato, que seria o objeto litigioso do processo, e pedido em sentido estrito, que seria o "pedido" do qual tratamos: "Nessa correlação que

\footnotetext{
${ }^{146}$ A definição retrata exatamente a ambiguidade de que sofre o termo e é um bom começo na tentativa de solucionar o complicado problema de delimitação de um conceito. Pela sua abrangência, acaba por retratar uma gama de questões - não muito bem resolvidos - a pairar sobre o que é (rectius o que deve ser) efetivamente "pedido" para o processo civil brasileiro. A definição resume diferentes posições, correlacionando o pedido com ação, demanda, mérito, técnica processual, objeto litigioso do processo, pretensão, relação de direito material, tutela jurisdicional (solução) e vontade da parte. Cf. Milton Paulo de Carvalho, O pedido no processo civil, 1992, p. 97.
} 
deve existir entre pedido e sentença, entende-se por pedido 'o conjunto formado pela causa (ou causae) pretendi e o pedido em sentido estrito". ${ }^{147}$

Pedido, portanto, não é "conteúdo", é uma parte, um elemento, de um ato formal de natureza linguística (i.e. demanda) que possui um certo conteúdo. Se de um modo geral a demanda - que o contém - é um ato linguístico, exteriorizado por letras, palavras e orações expostas em um suporto físico, também o é o pedido. Trata de um elemento da demanda, expresso por meio de linguagem, que se submete a requisitos formais específicos (CPC, art. 286 e outros) e se caracteriza por um conteúdo específico: a solicitação de um ato de poder do Estado-juiz apto a trazer uma alteração da realidade favorável ao demandante.

Este, adicionalmente, se divide em dois (i) pedido imediato, representado pela vontade de se valer de uma específica técnica processual; e (ii) pedido mediato, representado vontade de obtenção de um bem da vida (transformação da realidade). Além disso, conforme veremos a seguir, o conteúdo do pedido, sozinho, não terá aptidão para individualizar uma demanda, dependendo sempre de referência às partes e à causa de pedir.

Nos itens seguintes, passaremos a analisar a relevância tanto do pedido imediato quanto do pedido imediato para a delimitação do objeto litigioso do processo.

\subsection{PEDIDO IMEDIATO: ESPÉCIES DE TUTELA JURISDICIONAL}

O pedido imediato representa a vontade da parte dirigida para a técnica processual. Tradicionalmente, dizemos que trata do "tipo de providência jurisdicional solicitada, isto é, declaração, constituição/desconstituição ou condenação do réu que, nesta medida, determina a natureza da ação". ${ }^{148}$

O demandante tem, no processo de conhecimento, a possibilidade de propor três espécies distintas de "ações" (rectius demandas) de modo a obter três distintas espécies de "sentenças" e depois de "tutelas jurisdicionais" (terminologia mais moderna): condenatória, constitutiva e declaratória.

\footnotetext{
${ }^{147}$ Cf. Nelson Nery Jr. "Mudança na causa de pedir”, Soluções práticas vol. 4, p 599.

148 Cf. Arruda Alvim, Manual de direito processual civil, vol. I, $7^{\text {a }}$ ed. p. 237; e Carlos Eduardo Stefen Elias, “As reformas processuais e o princípio da congruência entre sentença e pedido", RePro 158, p. 46.
} 
As espécies de tutela estariam relacionadas com as espécies de crise de direito material, a serem pacificadas pelo processo, e caberia ao demandante escolher - no seu pedido imediato - a técnica processual adequada à luz de seu pedido mediato. Assim é a lição de Dinamarco:

"todo litígio em juízo gira em torno de crises jurídicas trazidas pelo demandante em busca de eliminação e com o objetivo de receber solução favorável. A tutela desejada pelo autor consistirá (a) na certeza jurídica quando a crise exposta for exclusivamente de incerteza, a ser dirimida mediante sentença meramente declaratória; (b) na satisfação de um direito ordinariamente dependente de uma prestação do obrigado, quando se trata de crise de adimplemento e o autor busca a satisfação mediante atividades inerentes ao processo executivo; (c) na implantação de uma situação jurídico-substancial nova, quando o autor lamenta a existência ou inexistência de uma relação jurídica e pede sentença constitutiva. Tais são os possíveis resultados do processo civil, a que o demandante pode aspirar quando vem demandar em juízo, obter efetivamente um desses resultados é obter a tutela jurisdicional". ${ }^{149}$

Ocorre que, compreendido assim, o pedido imediato se mostraria algo, senão inútil, de pequena relevância para o processo civil. Narrada uma crise de adimplemento (e.g. não pagamento de dívida) e pleiteada a satisfação compulsória do crédito (bem da vida), não há espaço para outro pedido imediato senão o de natureza condenatória. ${ }^{150}$

O mesmo valendo para os casos em que crises de $(i)$ certeza ou (ii) situação jurídica são indicadas como causa de pedir e o bem da vida almejado diz respeito a imposição do reconhecimento forçoso $(i)$ da inexistência ou existência de determinada relação jurídica; ou (ii) da criação, modificação ou extinção de determinada relação jurídica. Nestas hipóteses, ao pedido imediato não caberia outra função, senão a declaratória (positiva ou negativa) e a constitutiva (positiva ou negativa), respectivamente.

Isto importa dizer que, quanto a estas categorias processuais, não há verdadeira "opção" do demandante, mas um pedido certo e outro errado. O demandante, fundado no princípio dispositivo, escolhe o bem da vida que quer (pedido mediato), todavia, não

${ }^{149}$ Cf. Dinamarco, Instituições de direito processual civil, vol. II, p. 618; e Bedaque, Efetividade do processo..., 2005, p. 520.

150 A este ponto cabe apenas a ressalva daqueles que entendem que, mesmo quando crise de adimplemento fundamenta a demanda, o demandante teria a faculdade de pleitear tutela meramente declaratória; declaração do estado de inadimplemento. Cf. Andrés de la Oliva Santos, Objeto del processo y cosa juzgada en el proceso civil, p. 42. No entanto, resta claro que nestas hipóteses, o pedido mediato (bem da vida) almejado não é a satisfação do crédito, mas a eliminação da incerteza objetiva. Por este motivo, entendemos que a crise narrada deve ser necessariamente uma crise de certeza e o pedido deve ser declaratório, ainda que o caso trate de uma situação de inadimplemento. O motivo da demanda é a incerteza quanto à existência, ou não, do estado jurídico de inadimplemento, capaz de gerar várias consequências jurídicas, e não apenas o dever de cumprir a obrigação principal devida. 
escolhe livremente a técnica processual (pedido imediato), pois a escolha do bem da vida vai vincular - obrigatoriamente - a espécie de tutela jurisdicional demandada.

Desejando o cumprimento forçoso de uma obrigação, o demandante não tem escolha senão pela tutela condenatória, desejando a constituição, extinção ou modificação de uma situação jurídica, tem de pleitear uma tutela constitutiva e desejando uma certeza jurídica, tem de pleitear uma tutela declaratória.

A pequena importância desta noção de pedido imediato fica mais clara quando observamos que - mesmo sem qualquer correção formal - a jurisprudência admite a desconsideração deste pedido imediato, caso esteja em desconformidade com o pedido mediato, fazendo o bem da vida sempre prevalecer sobre o aspecto processual. Sendo clara a vontade da parte em se fazer cumprir uma obrigação, ainda que esta pleiteie textualmente uma tutela declaratória ou nomeie a ação como "declaratória", o bem da vida poderá lhe ser concedido, tal como pleiteado, desconsiderando-se a escolha (ou o erro) da parte quanto à indicação da técnica processual.

Identificamos isso especialmente em situações nas quais há maior possibilidade de incerteza, e.g. as hipóteses de nulidade relativa e nulidade absoluta dos contratos (CC, art. 166 e 171). Em princípio, as primeiras exigem tutela constitutiva enquanto as segundas tutelas declaratórias, todavia, caso a parte, por incerteza objetiva ou erro, fundamente sua demanda em nulidade relativa e pretenda a desconstituição do negócio por meio de "ação declaratória de nulidade", a opção pela técnica processual, por estar equivocada, deverá ceder à escolha relativa à tutela jurisdicional (bem da vida). O mesmo valendo para o caso oposto, no qual se pautando em nulidade absoluta a parte requer a desconstituição do contrato (anulação), quando deveria ter requerido a declaração de nulidade. É, assim, firme a jurisprudência do Superior Tribunal de Justiça no sentido de que "a natureza jurídica da ação é definida por meio do pedido e da causa de pedir, não tendo relevância o nomen iuris dado pela parte autora". ${ }^{151}$

Com base nestas constatações, podemos afirmar que, caso reduzíssemos o conceito de pedido imediato às referidas escolhas técnicas, i.e. entre tutelas condenatórias, declaratórias e constitutivas, teríamos de concluir pela sua diminuta importância, pois confrontada a escolha técnica com a vontade da parte (relacionada ao direito material), esta última sempre deverá ser privilegiada, por uma exigência da instrumentalidade do processo no seu aspecto negativo (instrumentalidade das formas).

${ }^{151}$ STJ, $2^{\text {a }}$ T., AgRg no REsp 594.308/PB, Rel. Min. Herman Benjamin, DJe 20/8/09. 


\subsection{PEDIDO IMEDIATO: CONCEITO MAIS AMPLO}

Tendo em vista a pequena relevância prática do conceito descrito no item anterior, entendemos que o pedido imediato - vontade do demandante relacionada à técnica processual - tem maior relevância quando a escolha processual diz respeito, não aos tipos de "demanda", "tutela" ou "sentença", mas ao procedimento (modelo-procedimental), ${ }^{152}$ especialmente nas hipóteses "tutelas diferenciadas" e de "fungibilidade de meios processuais". 153

\section{Expliquemos.}

Nas hipóteses de "fungibilidade de meios", o processo cuida de vários caminhos (procedimentos legais) admissíveis para a tutela do mesmo objeto litigioso, embora alguns caminhos possam ser mais ou menos econômicos e apresentar vantagens ou desvantagens (tutelas específicas), o que importa reconhecer é que estes são fungíveis, no sentido de que ao Estado-juiz "pouco importa" se o demandante optou por um ou por outro (não há irregularidade ou sanção de invalidade).

Por este motivo, cabe sempre à parte uma opção. Neste caso, a escolha da técnica processual não se limita ao certo e ao errado, ao adequado e ao inadequado (ao contrário da escolha entre os tipos de "ações" ou "tutelas"), de modo que o sistema permite que o demandante faça livremente escolhas quanto ao procedimento, à luz da conveniência. ${ }^{154}$

O melhor exemplo dessa possibilidade se encontra nas chamadas tutelas diferenciadas, nas quais o demandante pode escolher entre as vias "especiais" e as "comuns" do processo civil. ${ }^{155}$

Ao contrário do que ocorre nas tutelas condenatórias, declaratórias e constitutivas, não há uma técnica certa ou errada para uma determinada situação de direito material, mas

152 Esta parece ser a posição de Carlos Eduardo Stefen Elias, ao afirmar que o pedido imediato "determinará a natureza do processo e a forma do procedimento" (cf. "As reformas processuais e o princípio da congruência entre sentença e pedido", RePro 158, p. 46).

153 A respeito dos problemas correlatos ao termos "fungibilidade" e da noção específica de "fungibilidade de meios”, cf. Marcelo Pacheco Machado, Incerteza e processo, 2013, p. 78 e ss. e Flávio Luiz Yarshell, Tutela jurisdicional, $2^{\mathrm{a}}$ ed., p. 123.

${ }^{154}$ Heitor Sica ressalta claros limites à ideia de fungibilidade da qual tratamos aqui, afirmando que "há procedimentos especiais que outorgam ao autor tutela jurisdicional tão claramente mais eficiente, célere e adequada do que aquela prestada pelo procedimento comum ordinário, que lhe faltaria interesse processual para optar por este último". Para tanto, o autor falar em procedimentos especiais infungíveis, citando o exemplo da ação de desapropriação (Dec.-lei 3.365/1941) e busca e apreensão do bem móvel alienado fiduciariamente (Dec-lei 911/1969). (Heitor Sica, Reflexões em torno da teoria geral dos procedimentos especiais, RePro 208/66).

155 Cf. Ovídio Baptista, "Processo de conhecimento e procedimentos especiais", Da sentença liminar..., 2002, p. 97; Dinamarco, Instituições de direito processual civil, $2^{\mathrm{a}}$ ed., vol. I, p. 169. 
várias técnicas simultaneamente admissíveis para tutelar a mesma situação de direito material e a mesma pretensão da parte. Vejamos exemplos.

A jurisprudência é tranquila em reconhecer que "a monitória é uma faculdade do autor, que, não obstante preenchidos os requisitos do art. 1.102a, pode optar pelo procedimento comum ou sumário (RSTJ, 120/393: $4^{\mathrm{a}}$ Turma)". ${ }^{156}$ Isto importa dizer que, ainda que a parte possua "prova escrita sem eficácia de título executivo" e pretenda fazer cumprir obrigação de pagar quantia ou entregar coisa fungível ou de determinado bem móvel, preenchendo todos os requisitos de admissibilidade do procedimento monitório (especial), pode simplesmente optar pelo procedimento comum, sumário ou ordinário.

O mesmo raciocínio vale para o procedimento sumaríssimo dos juizados especiais cíveis estaduais, que pode ser objeto de simples opção do demandante, o qual estaria livre para escolher, de acordo com sua conveniência. Assim esclarece o art. $3^{\circ}, \S 3^{\circ}$, da Lei $n$. 9.099/05, que a utilização deste procedimento especial é uma mera opção do demandante que, mesmo preenchendo os requisitos mais específicos deste procedimento, pode ser valer - se quiser - do procedimento comum, ou de outro procedimento também admissível pela lei.

Outros procedimentos especiais, tais quais o de mandado de segurança ou ações possessórias, do mesmo modo, submetem-se à lógica da fungibilidade de meios. A lei autoriza o demandante a pleitear a mesma tutela pelo procedimento comum ou pelo mandado de segurança ou, ainda, a formular pedidos de natureza possessória (e.g. reintegração ou manutenção de posse) no procedimento especial previsto pelo art. 920 e ss. do Código de Processo Civil, ou no procedimento comum.

E mesmo dentro do procedimento comum há margem para a fungibilidade de meios, basta admitir que há, de fato, possibilidade de escolha entre o procedimento comum sumário e o procedimento comum ordinário. Mesmo tendo preenchido todos os requisitos do primeiro, a jurisprudência já pacificou o entendimento pelo qual a parte tem o direito de escolher o segundo. Nesse sentido, o Superior Tribunal de Justiça entende que "o emprego do procedimento ordinário, em vez do procedimento sumário ou mesmo especial, não é causa de nulidade do processo, pois prejuízo algum traz para o recorrente, uma vez que no rito ordinário a possibilidade de dilação probatória é mais ampla, em atendimento à garantia constitucional de ampla defesa". ${ }^{157}$ Flávio Luiz Yarshell acrescenta alguns

\footnotetext{
${ }^{156}$ Cf. Theotônio Negrão, Comentários..., p. 1073, art. 1.102a, nota 2.

${ }^{157}$ STJ, $1^{\text {a }}$ T., REsp 844.357/SP, Rel. Ministro Francisco Falcão, j. 26.09.2006.
} 
exemplos "quanto a esse sentido de fungibilidade", mencionando a livre possibilidade de escolha:

“a) entre ação rescisória e mandado de segurança para atacar sentença transitada em julgado; b) entre ação rescisória e declaratória de nulidade para desfazer sentença em processo com vício de falta ou nulidade de citação; c) entre a chamada ação de adjudicação compulsória e a dita ação condenatória dos arts. 466-A; 466-B e 466-C da Lei n ${ }^{\circ} 11.232 / 2005$; d) entre os embargos do devedor e os embargos de terceiro, em certas hipóteses". ${ }^{158}$

A este respeito, tivemos a oportunidade de ressaltar que esta concepção de fungibilidade (i.e. fungibilidade de meios) se aproxima da fungibilidade estabelecida no direito material (bens fungíveis e obrigações fungíveis - CC, arts. 85 e 249) na medida em que a ordem jurídica permite tanto o uso de um meio, quanto de outro, indistintamente. ${ }^{159}$ Qualquer dos caminhos escolhidos terá a mesma aptidão de conceder a tutela jurisdicional a quem tem direito, muito embora em determinadas hipóteses um caminho possa ser mais longo e custoso do que o outro.

Por este motivo, resta clara a relevância da manifestação da parte, não apenas quanto ao bem da vida e à espécie de tutela (declaratória, condenatória ou constitutiva), mas também passa a ser relevante a escolha quanto à técnica processual (procedimento a ser seguido), de tal modo que a noção de pedido imediato, tal qual tratada na presente tese, diz respeito não apenas às escolhas das partes quanto às espécies ou tipos de tutela jurisdicional, mas a toda e qualquer escolha processual feita na demanda.

\subsection{PEDIDO IMEDIATO, ESTABILIZAÇÃO DA DEMANDA E CORRELAÇÃO}

Verificamos que a vontade da parte quanto à técnica processual é relevante, tendo implicações para o procedimento, especialmente quando a lei faculta à parte livre escolha. O pedido imediato, por este motivo, tem pertinência para o processo civil, mas não tem aptidão para influir na delimitação do objeto litigioso do processo. Por este motivo, não

\footnotetext{
${ }^{158}$ Cf. Flávio Luiz Yarshell, Tutela jurisdicional, $2^{\text {a }}$ ed., pp. 127-128.

${ }^{159}$ Cf. Marcelo Pacheco Machado, Incerteza e processo, p. 79. Antes, já havia se manifestado a respeito Luiz Gustavo Tardin, Fungibilidade das tutelas de urgência, p. 147.
} 
serve como parâmetro para a individualização da demanda e, portanto, para a caracterização da conexão, continência, litispendência e coisa julgada.

Ao contrário do pedido mediato, da causa de pedir remota e das partes, o pedido imediato não é objeto de estabilização, nos termos da lei processual (CPC, art. 264, caput e parágrafo único). Este pode ser alterado, sem que isso implique posteriormente ofensa à correlação entre demanda e tutela jurisdicional, pois (i) não se trata de elemento essencial para caracterizar o objeto litigioso do processo e (ii) o juiz - como demonstrado acima tem controle sobre este pedido imediato, podendo - salvo nos casos em que há livre opção da parte - alterá-lo de ofício.

É evidente que esta alteração não pode ocorrer por mera liberalidade das partes, sob pena de grave prejuízo ao andamento do processo e possivelmente ao contraditório. Ocorre que, havendo vícios na escolha da parte, i.e. tendo ela escolhido o procedimento errado, o juiz estará autorizado - independentemente de manifestação das partes - a alterar o procedimento ex officio, determinado sua correção.

Esta afirmativa tem fundamento no dever geral de saneamento de irregularidades processuais, o qual exige do juiz $(i)$ avaliar se o descumprimento de formalidades trouxe algum prejuízo e, na resposta positiva, (ii) determinar a correção ou efetuar, ele mesmo, a correção dessas irregularidades. Por força de diferentes normas, o juiz estará autorizado a efetuar esta correção de ofício de modo a permitir que o processo prossiga e, ao fim, produza os efeitos desejados da Jurisdição (CPC, art. 284, 327 e $\S 4$ do 515). ${ }^{160}$

\subsection{PEDIDO MEDIATO: ASPECTO SUBSTANCIAL}

Se o pedido imediato ressalta o aspecto processual da vontade do demandante, que pode ou não ser relevante para o processo, o pedido imediato é representado pelo aspecto substancial. ${ }^{161}$ Já afirmamos que Chiovenda se valia da expressão bem da vida

\footnotetext{
${ }^{160}$ A este respeito já nos manifestamos: "Para que seja possível realizar essa conversão de meios, não há razão para exigirmos qualquer incerteza na técnica processual (dúvida objetiva). A possibilidade de desconsideração de irregularidades - quando ausente prejuízo -, bem como o dever geral de saneamento, não se justifica por dificuldades na aplicação da técnica, mas pela necessidade de garantir a efetividade do processo, imposta pela própria lei processual (CPC, arts. 284, 327 e 515, § 4º)". (Marcelo Pacheco Machado, Incerteza e processo, p. 83).

${ }^{161}$ Cf. Proto Pisani, Lezioni di diritto processuale civile, $5^{\mathrm{a}}$ ed., p. 57.
} 
(bene giuridico) para indicar o conteúdo do pedido mediato, tendo sido criticado pela imprecisão de seu conceito. ${ }^{162}$

A doutrina não teve condições de assentar, exatamente, do que isso trataria, de modo que há duas posições em geral. Vimos que, para Franchi, Proto Pisani e Ferri o pedido mediato representaria "o direito" que com a demanda "se propõe a obter, identificado com relação à realidade extraprocessual sobre a qual a decisão é destinada a incidir". ${ }^{163}$ Vimos, também, que Liebman diferentemente define pedido mediato como bem jurídico ao qual o provimento (representativo do pedido imediato) se refere, levando em consideração a coisa (jurídica e economicamente relevante) ao qual o provimento jurisdicional se direciona. ${ }^{164}$

$\mathrm{O}$ "direito pelo qual se pede tutela" não é critério suficiente para definir o pedido mediato. ${ }^{165}$ Em primeiro lugar, porque a ideia de "direito", aplicada nesse contexto, pode significar uma dezena de coisas distintas; conjunto de normas, norma concreta, enunciado jurídico aplicável ao caso, artigo de lei, texto legal, proposição normativa, etc. Em segundo lugar, porque o bem da vida não se encontra no plano jurídico (enunciados prescritivos), mas no plano da vida, da realidade que é regulada pelo direito.

Direitos (e efeitos jurídicos) são mero instrumento para a transformação da realidade, o ser humano se interessa fundamentalmente por estas (pelo que muda concretamente na sua vida) e não por aqueles (meras declarações), de modo que a pretensão do demandante se relaciona com um benefício concreto, factível, apto a ser concedido pelo Estado, e não apenas com o reconhecimento abstrato de um direito enunciado.

E isto se dá mesmo nas chamadas tutelas meramente declaratórias, nas quais se quer a pacificação, a "inquestionabilidade" da relação jurídica existente ou inexistente (força imperativa da declaração com todas as suas repercussões práticas, como alteração de registro civil, cancelamento de protesto, impedimento para cobrança, etc.), e não um simples enunciado declaratório.

Do mesmo modo, relacionar diretamente o pedido imediato com uma coisa ou um bem não é suficiente para delimitar todo o conteúdo da pretensão da parte. Em primeiro

\footnotetext{
${ }^{162}$ Cerino Canova, "La domanda giudiziale ed il suo conteunto", Commentario del codice di procedura civile, p. 34.

${ }_{163}$ Cf. Franchi, La litispendenza..., p. 88-91; Proto Pisani, Lezioni di diritto processuale civile, $5^{\text {a }}$ ed., p. 57; e Ferri, Struttura del processo, pp. 88-89.

${ }^{164} \mathrm{Cf}$. Liebman, Manuale di diritto processuale civile, $5^{\mathrm{a}}$ ed., 1992, p. 186.

${ }^{165}$ Cerino Canova, "La domanda giudiziale ed il suo conteunto", Commentario del codice di procedura civile, p. 34.
} 
lugar, há pretensões relativas a condutas humanas (fazer ou não fazer) ou ao estado das pessoas, que não podem ser reduzidas a coisas materiais ou mesmo bens incorpóreos. Em segundo lugar, porque mesmo quando tratamos de coisas físicas, estas podem ser incertas, fungíveis, e, portanto, inaptas a individualizar a demanda.

A preocupação das partes sempre está em uma transformação de seu cotidiano, com a agregação de seu patrimônio ou com a obtenção de outro benefício regulado pelo direito e de relevância para as partes (efeitos práticos da aplicação do direito), ainda que sem natureza patrimonial, tal como ocorre no direito da família (e.g. paternidade, divórcio, etc.), nos direitos de personalidade e nos direitos fundamentais (e.g. alteração de gênero, liberdade individual, etc.). ${ }^{166}$

Em conclusão: o bem da vida representa a mudança da realidade social favorável ao demandante e juridicamente protegida, que o comando judicial (sanctio juris da normaconcreta-sentença) pleiteado deve ter aptidão de provocar, atrelado aos atos executivos ou de cumprimento de sentença, e o pedido mediato é a manifestação da vontade da parte no sentido de que determinado bem da vida lhe seja conferido por meio da atividade jurisdicional.

\subsection{PEDIDO MEDIATO E BEM DA VIDA: DIFERENTES CRISES}

Conforme definimos acima, bem da vida é a transformação da realidade, produzida favoravelmente ao demandante pela aplicação do direito ao caso concreto. Por isso, o bem da vida não corresponde ou se limita ao mero efeito jurídico (principal) decorrente da sentença: seja pela constituição, desconstituição, declaração de existência ou inexistência ou pela imposição de uma ordem ou comando específico de pagar, fazer, não fazer ou de entregar ou dar coisa. Vai além e flerta com a aptidão de o processo alterar favoravelmente a vida do demandante, conferindo-lhe um benefício concreto que atue sobre a realidade dos fatos: um bem da vida, protegido pelo direito.

\footnotetext{
166 Mencionamos aqui que os efeitos desejados estão normalmente relacionados a uma norma de direito material, pois é este que regula a sociedade e as transformações que o direito está autorizado a provocar nela, em favor de diferentes sujeitos. Ocorre que, especialmente no caso da ação rescisória (com pedido meramente rescindente) é possível conceber a formulação de um pedido mediato que vise a aplicar somente os efeitos de uma norma caracterizada como processual, i.e. aquela que autoriza o desfazimento da coisa julga material em casos especiais (CPC, art. 485). O mesmo ocorreria nos casos de mandado de segurança contra ato judicial pautados no descumprimento do juiz de princípios constitucionais do processo.
} 
Este benefício pode ser obtido de diferentes modos, a depender das circunstâncias da crise de direito material e das normas aplicáveis ao caso concreto. A anulação de um contrato não é relevante para o demandante como "declaração jurídica", mas apenas na medida em que pode impedir a exigibilidade de eventual obrigação que dele venha advir. Do mesmo modo, a declaração de inexistência de "duplicata fria" não vale de per se como declaração jurídica, mas se torna (bem da vida) relevante na medida em que proíbe o demandado de levar o título a protesto ou a realizar qualquer ato de cobrança. Também a condenação ao pagamento de quantia não faz sentido apenas como "ordem" ou "comando", ao passo que a satisfação do credor só se estabelece quando seu patrimônio recebe acréscimo correspondente ao valor da obrigação. ${ }^{167}$

Nas demandas constitutivas, o efeito jurídico almejado pela parte será sempre a criação, a modificação ou a extinção de uma relação jurídica. O bem da vida, por sua vez, tem natureza menos específica, pois representa todas as consequências práticas a serem obtidas a partir da produção desta nova situação jurídica trazida pelo processo.

$\mathrm{O}$ bem da vida nas demandas constitutivas atinge o conjunto de proteções concedidas ao demandante (tutela jurisdicional), no sentido de que, não apenas este novo estado jurídico será produzido, mas que também os sujeitos do processo (ou quiçá terceiros ${ }^{168}$ ) deverão respeitar todas as suas repercussões possíveis. Estes ficam proibidos de adotarem um conjunto de comportamentos incompatíveis com a nova situação jurídica.

Tanto isso é verdade, que em demanda constitutiva negativa de título de crédito, uma vez acolhido o pedido do autor, não é necessária nova demanda (com pedido condenatório a obrigação de não fazer) para impedir que este mesmo título seja levado a protesto. Isto ocorre, pois o pedido de "desconstituição do título" não significa a vontade da parte no sentido de que seja produzido este mero efeito jurídico de desconstituição, mas "proteção jurídica completa", representada pelo impedimento de o demandado realizar qualquer conduta incompatível com a extinção desta relação jurídica.

A tutela constitutiva impõe um dever às partes, no sentido de que estes respeitem ou os efeitos da relação jurídica constituída ou modificada ou os efeitos decorrentes da impossibilidade de exigir qualquer efeito a partir de relação jurídica reconhecida como inexistente (extinta).

\footnotetext{
${ }^{167}$ Nesse sentido, podemos falar em efeitos secundários da sentença. Cf. Liebman, Eficacia y autoridad de la sentencia..., p. 91 e ss.

${ }^{168}$ A este respeito, cf. José Rogerio Cruz e Tucci, ao tratar das claras distinções entre efeito da sentença e coisa julgada, declarando que "para que a sentença possa produzir efeitos em relação à situação jurídica de terceiros é necessária a existência de um vínculo jurídico entre duas relações". (Limites subjetivos da eficácia da sentença, p. 173).
} 
Nas demandas declaratórias, fenômeno similar ocorre. O pedido é formulado no sentido de que a Jurisdição emita um ato de poder declarando que (i) determinada relação jurídica apontada como inexistente, de fato, existe ou que (ii) determinada relação jurídica apontada como existente, na realidade, inexiste. $\mathrm{O}$ bem da vida, porém, não se restringe a esta declaração, vai além, significa a proteção que o Estado pode dar ao demandante, impedindo que o demandado e alguns casos também terceiros se comportem de modo incompatível com este reconhecimento judicial.

Quando se propõe demanda declaratória, não se almeja a mera declaração jurídica, mas a transformação da realidade que esta declaração - emitida por ato de poder jurisdicional - pode provocar. Transformação esta que vai do estado de paz e tranquilidade do demandante até a garantia de que o demandado estará vinculado à relação jurídica declarada inexistente ou impedido de se valer de qualquer (pseudo)efeito da relação jurídica declarada inexistente. A alteração de registro civil, de registro de imóveis ou o cancelamento de protesto são efeitos práticos decorrentes da declaração (efeitos anexos da sentença) que não se confundem com o efeito jurídico principal (mera declaração), mas que integram o bem da vida almejado pela parte.

A título de exemplo, podemos observar a amplitude dos efeitos produzidos por sentença que acolhe pedido declaratório de inexistência de relação cambial. Nesse caso, obtemos, não uma simples declaração de certeza, mas também comandos genéricos contra o demandado, que fica proibido de realizar qualquer conduta incompatível com a inexistência jurídica desta relação, tal qual realizar protesto, encaminhar cobrança, negativar o demandante em órgão de proteção ao crédito, incluir o nome do demandante em cadastro de devedores, etc.

Nesse sentido, a tutela declaratória está sempre relacionada a um dever genérico, i.e. o dever de (i) não negar a existência de uma posição jurídica que existe; ou (ii) de não afirmar a existência de uma inexistente posição alheia. Declarar uma relação jurídica existente, ou não, significa impor às partes o dever de respeitar as consequências decorrentes da existência/inexistência desta mesma relação, efeito próximo ao de uma condenação, mas com maior abrangência.

O comando meramente declaratório seria assim mais bem enunciado: $(i)$ o demandado está obrigado a se comportar nos moldes da relação jurídica declarada existente; ou (ii) o demandando está proibido de exigir do demandante comportamento nos moldes da relação declarada inexistente. 
Diferentemente das tutelas constitutivas e declaratórias, a tutela condenatória tem sentido mais específico. Se as tutelas declaratórias visam a um reconhecimento genérico que permita impedir que o demandado atue de modo incompatível com a relação jurídica declarada e se as tutelas constitutivas impedem que o demandado ignore os efeitos na nova situação jurídica (ou a ausência deles), nas tutelas condenatórias busca-se apenas um aspecto da relação de direito material. ${ }^{169}$

É dizer, não se quer impor às partes o respeito a todas as repercussões de uma data relação de direito material, mas um aspecto individualizado. ${ }^{170}$

A relação jurídica de crédito/débito é ampla e implica a existência de várias faculdades (renunciar, ceder, exigir), mas quando fundamenta pedido condenatório, apenas uma destas faculdades é exercida; aquela que diz respeito ao direito de exigir o cumprimento forçado da obrigação (pretensão-faculdade). ${ }^{171} \mathrm{O}$ mesmo ocorre quando se obriga alguém a fazer ou não fazer algo em com base no direito de propriedade. Esta relação jurídica (direito real) é amplíssima e configura vários poderes (CC, art. 1.228), no entanto, pela tutela condenatória (ação reivindicatória) apenas uma faceta desta relação jurídica é exaltada, o direito de reaver a coisa.

Assim, o proprietário pode usar gozar e fruir da coisa, mas na tutela condenatória tem o objetivo de simplesmente reaver a coisa do réu que injustamente a possui. Os outros

\footnotetext{
${ }^{169}$ Antonio Junqueira de Azevedo fala que um direito subjetivo implica sempre em exigibilidades; a de reconhecimento ou exigibilidade mínima e a comum ou exigibilidade própria. Até a data de vencimento da obrigação, está tem somente a exigibilidade mínima, restrita ao dever de reconhecimento do débito. Após o vencimento, a obrigação passa a ter exigibilidade própria. Por este motivo, o autor fala que nos casos de obrigações de prestar declaração de vontade a exigibilidade própria seria praticamente absorvida pela exigibilidade mínima. Para Junqueira de Azevedo, nas ações declaratórias, a pretensão seria pautada apenas em exigibilidade mínima, enquanto que as condenatórias teriam como pressuposto a exigibilidade própria. (Conceito, identificação e conexão de causas no direito processual civil, 1967, pp. 23-24).

170 A linha aqui seguida se aproxima do pensamento de Fazzalari, segundo o qual nas demandas condenatórias, a situação substancial corresponderia às circunstâncias de fato que configurariam a "desobediência do dever substancial posta serviço do direito subjetivo e, portanto, à lesão deste". Nas demandas declaratórias, deve ser devidamente identificado o "dever de não contestar o patrimônio alheio, negando a existência de uma posição jurídica que existe, ou afirmando a existência de uma inexistente posição alheia". Por fim, nas demandas constitutivas, deve-se também considerar a não observância de um dever, especialmente nas hipóteses de anulação ou mesmo rescisão de um contrato, na medida em que a sentença dela decorrente pressupõe a violação de comando emergente da lei que, por sua vez, autoriza a extinção, criação ou modificação de situação jurídica. Para Fazzalari, portanto, a situação substancial se resume (i) num dever e na sua respectiva transgressão: o dever existe porque existe uma norma, que prescreve uma determinada conduta, e porque, num dado caso concreto, determinado sujeito agiu em sua desconformidade; e (ii) no direito subjetivo correspondente ao dever, e na lesão correspondente ao seu descumprimento: pelo prisma inverso, o descumprimento do dever por determinado sujeito implica no nascimento do direito de outro sujeito, especialmente no âmbito civil, donde da lesão ao direito exsurge a pretensão do sujeito ativo. (Instituzioni di diritto processuale, p. 233-4).

171 A este respeito Miguel Teixeira de Sousa ressalta que a exigibilidade é apenas uma das várias potencialidades da relação de direito material, cf. $O$ concurso de títulos de aquisição da prestação..., Coimbra, Livraria Almedina, 1988, p. 22.
} 
aspectos da relação de direito material não mantém pertinência com o bem da vida, nesta hipótese.

Em síntese: a amplitude e o sentido do bem da vida deve variar em decorrência da natureza da relação de direito material e da crise jurídica adjacente (certeza, situação jurídica ou adimplemento) bem como da amplitude da regra de direito material, invocada como fundamento do pedido. Tudo isso será analisado a luz da interpretação do ato linguístico, conforme veremos no Capítulo $I V$.

\subsection{NECESSIDADE DE VINCULAÇÃO DO CONTEÚDO DO PEDIDO À CAUSA DE PEDIR}

O pedido, para fazer sentido, depende sempre de uma referência a determinados sujeitos (que deverão sofrer estes efeitos jurídicos) e a determinados fatos (que seriam responsáveis por desencadear estes efeitos jurídicos), uma vez submetidos à norma jurídica pertinente.

Não entendemos ser possível, tal como defendido por parte da doutrina pátria e estrangeira, que o objeto litigioso do processo seja determinado apenas pelo pedido, sem referência aos sujeitos e à causa de pedir, tal como faz aparentemente Dinamarco ao dizer: o objeto litigioso do processo é a "pretensão a um bem da vida, quando apresentada ao Estado-juiz em busca de reconhecimento ou satisfação. É o material sobre o qual atuam as atividades jurisdicionais exercidas pelo juiz e todos os atos de defesa judicial dos direitos, realizados pelas partes". ${ }^{172}$

A referida noção de petitum - por ser excessivamente genérica - não permite a individualização de um objeto de um processo específico, de modo a diferenciá-lo dos demais. ${ }^{173} \mathrm{O}$ próprio Dinamarco, embora mantenha a afirmação de que o objeto litigioso do processo residiria no pedido, noutro trecho do mesmo trabalho reconhece ser inquestionável a necessidade de se recorrer à causa de pedir para sua individualização:

\footnotetext{
“Com essa conceituação e esse modo de inserir-se no processo civil de resultados, o objeto litigioso do processo consiste exclusivamente no pedido formulado pelo demandante. É ali que reside a pretensão cujo reconhecimento e satisfação o demandante quer. A utilidade do processo
}

\footnotetext{
${ }^{172}$ Dinamarco, Instituições de direito processual civil, vol. II, pp. 180-181.

${ }^{173}$ Esta questão foi expressamente tratada por Cruz e Tucci, cf. A causa pretendi no direito processual civil brasileiro, $2^{\mathrm{a}}$ ed., p. 159.
} 
reside precisamente nisso, na capacidade de absorver pedidos e dar-lhes afinal a solução prática conveniente segundo o direito. Prover o pedido é dar a tutela jurisdicional ao autor; desprovê-lo, ao réu. Os fundamentos de fato e de direito que o demandante inclui na demanda têm o objetivo de construir o raciocínio lógico-jurídico que, segundo ele, conduz ao direito afirmado - mas nenhuma vantagem prática recebe o autor ou o réu, em sua vida externa ao processo, só pelo acolhimento ou rejeição da causa de pedir". ${ }^{174}$

Daí, ainda que se entenda que a satisfação do demandante se dá pelo pedido, e não pela causa de pedir, é inexorável a necessidade de uma referência à "situação de direito material" (teoria da individualização) ou da referência aos fatos concretos (teoria da substanciação) alegados pelo demandante para se individualizar um objeto litigioso do processo.

Nesse ponto, a crítica de Fazzalari e Proto Pisani é muito pertinente: não é possível falar na identificação do objeto litigioso do processo tão somente a partir da ideia de pedido, na medida em que este pressupõe contextualização, e abstratamente não se distingue de outros pedidos qualitativa e quantitativamente idênticos. Duas partes podem, com base em diferentes negócios jurídicos, dar ensejo à formação de duas ou mais demandas com o mesmo pedido e pautadas na mesma "situação jurídica", e.g. entrega de um mesmo fusca azul, pautada em dois contratos de depósito, firmados em diferentes meses e com o mesmo objeto (cf. item 2.9).

Do mesmo modo, e conforme já advertia Bellavitis, no primeiro quartel do século passado, a referência a simples fatos, sem contextualização, é carente de sentido e, portanto, inapta a designar o conteúdo da demanda. Os fatos jurídicos, antes de serem jurídicos, são fatos sociais, de modo que não existem em si mesmos, mas somente podem ser identificados a partir de um critério lógico que os tome como base. Por isso, na designação da causa de pedir, os fatos devem ser enxergados sobre o prisma da norma jurídica aplicável (sua fattispecie), que toma alguns e exclui outros de sua referência, separando aqueles fatos sociais relevantes para a demanda daqueles irrelevantes. ${ }^{175}$

\footnotetext{
${ }^{174}$ Instituições de direito processual civil, 2005, vol. 2, item 481.

175 Savigny sustentou em primeiro lugar a existência da matéria, correspondente "à relação em si mesma", e em segundo lugar da determinação jurídica dessa matéria. (Cf. Sistema de derecho romano actual..., I, pp. 248-249). Bellavittis nega a possiblidade de tal distinção: "Temos em última análise para a identificação da relação jurídica que considerar dois elementos: objetivação da norma jurídica e subjetivação da norma jurídica: isto é desenvolvimento dos fatos e justaposição da norma, até a posição recíproca de objeto (prestação) e sujeitos: a norma em resumo não pode ser mais isolada e considerada como elemento em si mesmo, mas sempre em relação aos outros dois elementos (objeto e sujeitos) somente como a relação de fato deve ser sempre considerada, mas não pode ser considerada, salvo se em relação à norma". (Bellavittis. M. L'indentificazione delle azione, 1924, pp. 98-100).
} 
O que se sustenta aqui, portanto, é que a causa de pedir deve ter uma referência fática e uma referência jurídica contemporânea, a individualizar a demanda ao lado das partes e do pedido. ${ }^{176}$

\subsection{CAUSA DE PEDIR: ASPECTO FÁTICO E ASPECTO JURÍDICO}

A causa de pedir, de um modo geral, é definida como os motivos que levam à formulação do pedido. Em nosso sistema, a doutrina cogita inicialmente dois elementos distintos que integrariam a causa de pedir: a causa de pedir fática (remota) e a causa de pedir jurídica (próxima).

A causa de pedir fática ou remota seria constituída pela descrição ou alegação dos fatos aptos - uma vez subsumidos às normas pertinentes - a produzirem os efeitos jurídicos pretendidos no pedido. Cuidamos dos fatos relevantes, dos acontecimentos da vida narrados nas suas miudezas (teoria da substanciação) e que de acordo com as afirmações do demandante seriam aptos da constituírem o direito demandado (efeitos jurídicos). ${ }^{177}$ Mas o que seriam estes fatos?

São fatos, não apenas comportamentos humanos que tenham se desenvolvido por um tempo determinado, mais ou menos amplo, como uma conduta, uma omissão, um ato ilícito, um inadimplemento, mas também "estados de coisas e de pessoas sem duração determinada". ${ }^{178}$ Isto é, não apenas algo que se fez ou se deixou de fazer, em determinada data, é um fato, como também um estado de coisas, como uma posse ou uma detenção mantida por determinado sujeito em relação a um determinado bem, que se prolonga no tempo. $^{179}$

${ }^{176}$ O Superior Tribunal de Justiça nesse sentido entende que: "Há violação aos arts. 128 e 460 do CPC se a causa é julgada com fudamento em fatos não suscitados pelo autor". (STJ, $3^{\mathrm{a}}$ T., REsp 746.622, Rel. Ministra Nancy Andrighi, j. 26.09.2006). Cf. Theotonio Negrão, Código de Processo Civil..., 43ª ed., p. 521.

177 Os fatos em si mesmos são eventos da vida, passados, e que não se manifestam in natura no processo ou na demanda. Por isso, esta é constituída, não por fatos, mas por alegações de fatos, fatos descritos i.e. reconstruções linguísticas de um suposto evento fático.

${ }^{178}$ Cf. Andrés de la Oliva Santos, Objeto del processo y cosa juzgada en el processo civil, pp. 51-52.

${ }^{179}$ Em relação a este ponto, foi a crítica de Heinitz a Chiovenda, o qual teria se valido de conceito de "fato" exageradamente amplo a designar a causa pretendi, conceito este que abarcaria a propriedade indevidamente como um fato. Cf. Heinitz, I limitti oggettivi della cosa giudicata, 1937, p. 148. Entendemos, no entanto, que até certo ponto, não estava equivocado Chiovenda ao afirmar que a propriedade pode ser um fato. Não negamos que a propriedade seja um efeito jurídico ou direito subjetivo ou relação jurídica que decorre de um ou vários fatos, assim determina o art. 1.227 do Código Civil: uma vez ocorrido o registro no cartório da escritura de compra e venda, deve ser a aquisição da propriedade pelo adquirente sobre determinado bem imóvel. No entanto, a mesma relação de propriedade pode ser considerada um fato jurídico. 
Também podem ser fatos, aptos a integrarem a causa de pedir, os chamados fatos jurídicos stricto sensu, que representam acontecimentos da vida que não dependem da vontade humana, tais quais os fatos da natureza. Já nos referimos a estes quando afirmamos que "tempestades", "furacões", "inundações" podem ser fatos juridicamente relevantes, inclusive com efeitos para a própria relação jurídica processual (CPC, art. 183 e $\S \S)$. Exemplificativamente, podemos dizer que uma enchente que gere danos a uma residência é fato jurídico relevante para uma pretensão ao pagamento de seguro ou mesmo um raio que atinge uma casa e gera danos pode dar ensejo à mesma pretensão. ${ }^{180}$

Em todos os casos, não obstante suas características efetivas, temos de tratar de fatos juridicamente relevantes, aos quais o direito atribua abstratamente algum efeito e que, em concreto, possa fundamentar a outorga de alguma tutela jurisdicional. Para Junqueira de Azevedo:

"direito subjetivo é a posição de vantagem que, da incidência da norma sobre um fato, resulta para uma pessoa, a propósito de um objeto. Obrigação é a posição de vantagem surgida de um fato jurídico; relação jurídica é a ligação entre duas pessoas, uma em vantagem e outra em desvantagem, originada nas mesmas condições. Portanto, direito subjetivo, obrigação e relação jurídica são consequências de fato jurídico". ${ }^{181}$

Estes fatos surgem na demanda, não como fatos in natura, mas como alegações, reconstruções linguísticas de fatos. A linguagem utilizada para tanto é descritiva e se dirige a acontecimentos pretéritos (e.g. lesões a direitos) ou mesmo a expectativas quanto a

Isto ocorre, pois determinadas normas jurídicas tomam a propriedade de determinado sujeito em relação a determinado bem como antecedente normativo (fattispecie) atribuindo a partir daí consequências jurídicas variadas, tal como ocorre com o art. 1.228 do Código Civil, o qual, entre outras normas, autoriza a seguinte proposição: se proprietário, deve ser o direito de usar, gozar e fruir do imóvel, no qual a propriedade é fato e o direito de usar, gozar e fruir é o efeito (consequência) jurídica desencadeada a partir da verificação daquele.

${ }^{180}$ Em relação a este ponto, foi a crítica de Heinitz a Chiovenda, o qual teria se valido de conceito de "fato" exageradamente amplo a designar a causa pretendi, conceito este que abarcaria a propriedade indevidamente como um fato. Cf. Heinitz, I limitti oggettivi della cosa giudicata, 1937, p. 148. Entendemos, no entanto, que até certo ponto, não estava equivocado Chiovenda ao afirmar que a propriedade pode ser um fato. Não negamos que a propriedade seja um efeito jurídico ou direito subjetivo ou relação jurídica que decorre de um ou vários fatos, assim determina o art. 1.227 do Código Civil: uma vez ocorrido o registro no cartório da escritura de compra e venda, deve ser a aquisição da propriedade pelo adquirente sobre determinado bem imóvel. No entanto, a mesma relação de propriedade pode ser considerada um fato jurídico. Isto ocorre, pois determinadas normas jurídicas tomam a propriedade de determinado sujeito em relação a determinado bem como antecedente normativo (fattispecie) atribuindo a partir daí consequências jurídicas variadas, tal como ocorre com o art. 1.228 do Código Civil, o qual, entre outras normas, autoriza a seguinte proposição: se proprietário, deve ser o direito de usar, gozar e fruir do imóvel, no qual a propriedade é fato e o direito de usar, gozar e fruir é o efeito (consequência) jurídica desencadeada a partir da verificação daquele.

181 Antonio Junqueira de Oliveira, Conceito, identificação e conexão de causas no direito processual civil, 1967, p. 21. 
eventos futuros (e.g. ameaças de lesões a direitos), de alguma repercussão jurídica, ao menos como tal apontada pelo demandante. Para Dinamarco:

\begin{abstract}
"narrar fatos significa descrevê-los como faz um historiador. Descrevem-se os acontecimentos em si mesmos, em sua autoria e em suas circunstâncias de modo, lugar e tempo. Fatos descritos são segmentos da História, ou eventos da vida, aos quais o demandante atribui a eficácia de lhe conferir o direito alegado e a necessidade da tutela jurisdicional postulada. Das dimensões que tiverem dependerão os limites da sentença a ser proferida, a qual não pode apoiar-se em fatos não narrados (art. 128); bem como os da coisa julgada que sobre ela incidir, a qual não impedirá a propositura de outra demanda, fundada em outros fatos (infra, nn. 946 e 960). Da precisão na narrativa dos fatos depende também a possibilidade de uma defesa eficiente, pelo réu". ${ }^{182}$
\end{abstract}

A causa de pedir jurídica ou próxima, por sua vez, também é caracterizada por alegações. Todavia, não se alega "fatos" tal como concebidos acima, mas o "direito", i.e. reconstrói-se linguisticamente a norma jurídica aplicável ao caso. ${ }^{183}$

Nesse sentido, temos duas ideias a denotar a causa de pedir jurídica, seria ela constituída pela (i) a descrição das normas jurídicas aplicáveis ao caso, i.e. proposições jurídicas aptas a produzirem os efeitos pretendidos com o pedido; ou pela ( $i$ i) a descrição ou indicação do enquadramento dos fatos narrados como causa de pedir remota às normas jurídicas (proposições normativas) que, uma vez aplicáveis, seriam aptas a produzirem os efeitos pleiteados com a demanda.

A diferença entre as duas acepções está em que a primeira concebe a causa de pedir como a mera descrição do conteúdo da norma jurídica aplicável (estaticamente) ao passo que a segunda concebe-a como a descrição do fenômeno de subsunção do fato à norma (dinamicamente).

Uma coisa seria afirmar o conteúdo da norma aplicável (e.g. o proprietário tem o direito de reaver a coisa em face de quem injustamente a possua), outra seria descrever de qual modo aquela norma (proposição normativa) incidiria ao fato concreto narrado, de

\footnotetext{
${ }^{182}$ Cf. Dinamarco, Instituições de direito processual civil, vol. II, item 450.

${ }^{183} \mathrm{O}$ direito aplicável ao caso é constituído de enunciados prescritivos, é dizer, de linguagem que exerce a função prescritiva: de "fazer com que um estado de coisas seja modelado conforme as palavras enunciadas". Diferentemente, a linguagem meramente descritiva tem como objetivo estabelecer correspondência com a realidade, dizendo - não como as coisas deveriam ser - mas como as coisas são. (cf. Osly da Silva Ferreira Neto, Ações tributárias coletivas, 2013, p. 24). Esta distinção é relevante, pois a causa de pedir fática é constituída pela descrição de fatos relevantes para o surgimento da pretensão manifestada por meio do processo, em linguagem claramente descritiva. A causa de pedir jurídica, por sua vez, embora trate do direito, é também constituída de linguagem descritiva, porém, visa a descrever o estado (como é) da linguagem prescritiva do direito positivo. Isto é: diz como é (descreve) a linguagem do direito aplicável ao caso que, por sua vez, tem função distinta, de natureza prescritiva.
} 
modo a produzir os efeitos pretendidos no pedido (e.g. considerando que o autor é proprietário e que o réu retém a coisa injustamente, aquele tem o direito de reaver a coisa em face deste).

A distinção, porém, é sutil, eis que ao indicarmos o conteúdo da norma aplicável ao lado dos fatos descritos na causa de pedir remota - tendemos a demonstrar ainda que de modo tácito o fenômeno da incidência, especialmente se pressupormos a indicação da norma correta, que efetivamente se adequa a aqueles fatos. Por este motivo, não há grandes repercussões práticas na distinção entre os fenômenos, especialmente porque, conforme veremos, o juiz ao julgar a causa estará livre para realizar subsunção distinta daquela descrita pelo demandante (iura novit curia).

Outro ponto relevante reside na distinção feita pela doutrina, quanto ao conteúdo da causa de pedir próxima, entre fundamento jurídico e fundamento legal. O primeiro estaria relacionado às "categorias jurídicas" aplicáveis ao caso, tais como a propriedade, a responsabilidade civil aquilina, a responsabilidade contratual, a relação de paternidade, etc., que podem - em alguns casos - decorrer de diferentes dispositivos legais. O segundo seria um critério eminentemente formal, representado pela indicação das referências numéricas dos diplomas normativos (veículos de introdução de normas) que conteriam as normas jurídicas aplicáveis ao caso, tais como art. 1.228 do Código Civil, art. 927 do Código Civil, Cláusula X do Contrato, etc.

O demandante não possui ônus de indicar os dispositivos da lei ou do contrato que fundamentariam a sua pretensão, por este motivo, o fundamento legal é elemento de pequena relevância, não sendo considerado parte integrante da causa de pedir jurídica ou sequer requisito de validade da petição inicial. ${ }^{184}$

Assim, resta-nos como causa de pedir jurídica apenas a indicação do conteúdo da norma jurídica aplicável aos fatos narrados como relevantes e, em tese, apta a produzir os efeitos jurídicos pleiteados por meio do pedido, ainda que sem a indicação do diploma normativo, veículo introdutor da norma no sistema jurídico, ou sem a descrição da forma

\footnotetext{
${ }^{184}$ A este respeito, Bedaque leciona que, adotando-se a premissa da possibilidade de o juiz alterar a fundamentação jurídica da demanda com base no iura novit curia, "torna-se difícil, senão inócua, a distinção entre fundamento jurídico e fundamento legal". "Os elementos objetivos da demanda à luz do contraditório", Causa de pedir e pedido no processo civil, p. 32. No mesmo sentido, cf. Juvencio Vasconselos Viana, "Causa de pedir no processo de execução", Causa de pedir e pedido no processo civil, p. 99.
} 
de incidência do fato à norma que, como visto, tratando-se de uma petição inicial apta, poderá ser facilmente deduzido. ${ }^{185}$

\subsection{CAUSA DE PEDIR PRÓXIMA E INDIVIDUALIZAÇÃO DA DEMANDA}

A causa de pedir próxima ou jurídica, a despeito de constar textualmente na lei como um dos requisitos de validade da petição inicial (CPC, art. 282) e de justificar reiterada análise na doutrina é de menor relevo para a individualização da demanda, especialmente por força o princípio do iura novit curia.

Este princípio, enunciado em latim, não possui fonte no direito romano. $\mathrm{Na}$ verdade, a expressão foi desenvolvida paulatinamente de modo a assumir diferentes sentidos. Inicialmente $(i)$ nos remete à ideia de que apenas os fatos (alegações de fato) deveriam ser objeto de prova, sendo inadmissível a exigência de prova quanto ao direito, pois este seria presumivelmente de conhecimento do juiz; em segundo lugar, em segundo lugar, também (ii) significa que a aplicação do direito seria assunto do juiz, de modo que as partes não estariam obrigadas a enunciar, em sua demanda, a subsunção do fato à norma, indicando causa de pedir jurídica; por fim, (iii) significa que o juiz não deve se inquietar por causa das opiniões jurídicas das partes, tendo a possibilidade de aplicar norma jurídica distinta daquela alegada. ${ }^{186}$

Os três sentidos referidos são abarcados pelo nosso direito positivo, com pequenas exceções, tal como determinam os artigos 337 e 126 do Código de Processo Civil. No entanto, o que agora nos interessa é o sentido previsto no item "iii", pelo qual, ainda que não alegada pelas partes ou contida na demanda, e desde que respeitados os fatos narrados como causa de pedir remota e o pedido formulado, o juiz poderá aplicar norma jurídica distinta para julgar o pedido.

Desde que o juiz respeite as alegações de fato (causa de pedir remota) e não conceda nada a mais, a menos ou diferente do que foi delimitado no pedido, este estará

\footnotetext{
${ }^{185}$ Proposição jurídica é o sentido que se extrai a partir de um enunciado jurídico. A respeito da definição de proposição jurídica, cf. Kelsen, Teoria pura do direito, 2003, p. 80 e ss; e Tárek Moyses Moussallem, Revogação em matéria tributária, 2005, p. 35.

186 Cf. Fritz Baur, "Da importância da dicção iura novit curia", RePro 3, p. 169 e ss; e Dinamarco, Vocabulário do processo civil, 2009, p. 352.
} 
plenamente livre para invocar normas distintas daquelas trazidas pelas partes no debate jurídico conduzido no processo, decidindo assim a causa.

Ante esta possibilidade, a causa de pedir jurídica passa a se mostrar de todo irrelevante para a individualização da demanda, não apenas a demanda continua a mesma, caso o juiz entenda por ignorar a causa de pedir jurídica invocada, como também não importa em nenhuma violação jurídica o julgamento que opta por ignorá-la. ${ }^{187}$

Em referência à disposição da ZPO alemã que exige na demanda a invocação da lide "sobre o plano dos fatos e do direito", Fritz Bauer afirma que, do ponto de vista da dicção iura novit curia seria ela oposta ao brocado. "Pois se não é do interesse das partes invocar a norma aplicável, segundo elas mesmas, e mesmo que a omissão de tal menção fosse sem objeto, a disposição citada não seria significado". Continua afirmando que "é ainda uma disposição dificilmente compreensível, se o conhecimento do direito é, unicamente, assunto respeitante ao juiz". O autor, nesse sentido, esclarece que a exigência de enunciação do direito teria em vista "certas condições formais", tais quais as relativas à competência. ${ }^{188}$

O juiz se limita aos fatos narrados, não havendo limites para que os possa requalificar juridicamente, fazendo-os incidir a norma distinta daquela alegada pelo demandante. Conforme a lição de Cruz e Tucci, o limite está nos fatos que "individualizam a pretensão e que constituem a causa pretendi: nenhuma qualificação jurídica integra esta e, por via de consequência, nada obsta a livre eleição dos motivos ou normas jurídicas que o agente do Poder Judiciário reputar adequadas". 189

Partindo-se dessa premissa, podemos concluir que - ao menos para a identificação do objeto litigioso do processo - o foco deve estar nos fatos alegados como fundamento do pedido, sendo relevante a análise da norma jurídica, tão somente, como elemento de argumentação do demandante, a fornecer um melhor critério de convencimento ao juiz, mas por não o vincular e por não ser capaz de individualizar um processo não deverá ter relevância para a delimitação do objeto litigioso. ${ }^{190}$

\footnotetext{
${ }^{187}$ Cruz e Tucci nesse sentido sustenta ser desnecessária "a indicação do fundamento legal da demanda, bem como do seu respectivo nomen iuris", tendo em vista que, fundamentalmente por força do referido princípio, o juiz estará autorizado a fazer incidir, sobre normas distintas das indicadas pelo demandante, os fatos por ele mesmo narrados (cf. A causa pretendi no processo civil, $2^{\mathrm{a}}$ ed., p. 155).

${ }^{188}$ Cf. Fritz Baur, "Da importância da dicção iura novit curia", RePro 3, p. 169 e ss.

189 Cf. Cruz e Tucci, A causa pretendi no processo civil, 2a ed., p. 162; e Bedaque, "Os elementos objetivos da demanda à luz do contraditório", Causa de pedir e pedido no processo civil, p. 32.

${ }^{190} \mathrm{Na}$ perspectiva da individualização, a mera indicação da categoria jurídica (para muitos contida no próprio pedido), aliada ao apontamento dos sujeitos, seria suficiente para delimitar o objeto litigioso do processo, de modo que a causa de pedir fática (concebida como a descrição dos fatos constitutivos do direito) assumiria relevância nenhuma. Noutra perspectiva, pautando-se na teoria da substanciação, a descrição
} 


\subsection{COMO SE DELIMITA A CAUSA DE PEDIR REMOTA?}

Esclarecidas as circunstâncias relativas à causa de pedir jurídica, passemos a analisar a fática. E o problema começa pela constatação de que a narrativa que compõe uma demanda não retrata, toda ela, causas de pedir fáticas. Então como separamos o joio do trigo?

A petição inicial - documento físico pelo qual a demanda é mais comumente veiculada - pode ser uma peça caótica, com um sem número de alegações de fato, de distintas naturezas.

Nela, podem ser encontradas alegações meramente circunstanciais, relevantes apenas para a formação de presunções hominis (CPC, 335), que auxiliam a atividade cognitiva do juiz. Exemplo disso ocorre quando, em ação de guarda movida pelo pai em face da mãe, alega-se que a mãe frequentou casas de "costumes duvidosos", circunstância sozinha não justifica o deferimento/indeferimento do pedido, mas que - pautada no que normalmente acontece - poderia gerar a presunção hominis de que a mãe teria "vida pessoal" incompatível com a maternidade, não se mostrando a guarda em seu favor no melhor interesse do incapaz, isso sim fato jurígeno e causa de pedir para o deferimento da guarda unilateral em favor do pai, à luz do que determina do art. $1.583, \S 2^{\circ}$, I, II e III, do Código Civil.

Os fatos secundários ganhariam importância no processo, na medida em que, não conseguindo demonstrar a ocorrência do fato principal, o demandante recorreria a estes para, mediante presunções hominis, obter o reconhecimento de seu direito. Citemos mais um exemplo: numa ação de reparação de danos fundada em acidente aeronáutico, não tendo provas de que estava dentro do avião que se acidentou, o demandante pode alegar que ingressou no aeroporto, comprou a passagem, etc. (fatos secundários), na tentativa de levar o juízo a presumir seu ingresso na aeronave e sofrimento de supostos danos morais (fato essencial).

minuciosa dos fatos e a referência ao pedido seriam suficientes para determinar o objeto litigioso do processo, especialmente em função da possibilidade de o juiz qualificar livremente os fatos (iura novit curia). José Raimundo Gomes da Cruz, a respeito da teoria da substanciação, afirma que "se se tratar de acidente de trânsito e a responsabilidade decorrer de culpa, não bastará a mera e vaga referenda a esta ou à genérica ocorrência de imperícia, negligência ou imprudência. $\mathrm{O}$ autor deverá alegar o excesso de velocidade, ou a ultrapassagem proibida, ou o fato de o réu não manter distância razoável do veículo do autor, à sua frente etc". (cf. José Raimundo Gomes da Cruz, "Causa de pedir e intervenção de terceiros". Revista dos Tribunais. Vol. 662. N. 47. Dez. 2002. P. 47 e ss). 
Além disso, pode haver alegações de fato que visem ao convencimento sobre provas e que, do mesmo modo, não possuem nenhuma relevância para a definição da causa de pedir. Assim é que e.g. em ação de cobrança fundada em contrato questiona-se falsidade de assinatura e, logo na inicial, o autor alega que o réu possuiria doença que, por sua vez, faria com que sua assinatura sofresse vacilações e variabilidades, sem que isso permitisse qualquer questionamento quanto à sua manifestação de vontade.

Podem estar presentes, ainda, alegações de fato que dizem respeito ao processo (regras técnicas processuais), sendo relevantes para benefícios processuais, para a admissibilidade de procedimentos especiais ou tutelas diferenciadas, ou mesmo para a incidência de regras de competência. Vejamos exemplo: o autor alega na inicial e.g. que é pobre, de modo que possa se beneficiar da assistência judiciária gratuita (Lei 1060/1950, art. $4^{\circ}$ ), alega que é idoso (aporta sua data de nascimento) para se valer do benefício de tramitação previsto pela lei (Lei 10.741/2003, art. 71), alega que a obrigação tem fundamento em honorários profissionais, para poder se valer do procedimento comum sumário (CPC, art. 275, II, “f”) ou mesmo alega que o réu tem domicílio na localidade X ou $\mathrm{Y}$ ou mesmo que o contrato foi cumprido em tal lugar, para o fim de justificar a competência do juízo (CPC, art. 94 e ss.).

E mais. A petição inicial é complexa e, além das alegações mencionadas, pode conter a descrição de fatos absolutamente alheios à pretensão manifestada e de fatos absolutamente irrelevantes, que podem servir simplesmente à retórica, servir a alguma estratégia do advogado (lícita ou ilícita nos termos do art. 14 do CPC) ou mesmo decorrer de erro ou da má redação da peça processual.

Nenhuma destas alegações, todavia, a despeito de estarem presentes na petição, e fazerem parte do conteúdo do ato de demandar, deverão ser consideradas causa de pedir ou elemento apto a individualiza-la. Isto ocorre, pois estas mesmas alegações, simultaneamente, poderiam se mostrar presentes em diferentes demandas, sem propiciar que estas fossem idênticas, conexas ou se relacionassem, sequer, por afinidade.

Dito isto, a questão antes colocada permanece sem resposta: como diferenciar as alegações que constituem causa de pedir daquelas irrelevantes ao objeto litigioso do processo?

Para tanto, temos que levar em consideração que a demanda é um ato postulatório argumentativo, que tem o objetivo de levar o órgão jurisdicional a emitir um ato de poder 
com determinado conteúdo, e que deve conter - em seu próprio conteúdo - um projeto desse ato de poder estatal. ${ }^{191}$

Em outras palavras, a demanda almeja a produção de uma sentença, uma ou mais de uma norma jurídica concreta e, por consequência, o conteúdo da demanda deve conter um projeto dessas normas concretas almejadas, i.e. a descrição da incidência de um fato concreto a uma determinada norma abstrata (causa de pedir) que, por sua vez, deve acarretar a produção de determinados efeitos jurídicos (pedido), na seguinte estrutura: dado a ocorrência de tais fatos deve ser a produção de determinados efeitos.

O pedido representa a manifestação de vontade da parte, para que os efeitos decorrentes da incidência dos fatos à norma abstrata sejam produzidos naquele caso concreto, em relação àquelas partes. A causa de pedir, por sua vez, abrange todos os fatos uma vez aplicáveis à hipótese (fattispecie) daquela norma abstrata - aptos a desencadearem os efeitos almejados pelo demandante. ${ }^{192}$ Dinamarco ressalta que:

\begin{abstract}
"tanto quanto a sentença, a demanda estrutura-se logicamente como um silogismo, sabendo-se que a norma jurídico-material contém um preceito (sanctio juris) a ser imposto em casos concretos quando efetivamente ocorrerem os fatos descritos na tipificação genérica e abstrata que a norma contém (fattispecie). Na demanda, a premissa maior é a norma, com sua previsão de fatos e formulação do preceito a impor sempre que esses fatos aconteçam; a premissa menor são os fatos concretamente acontecidos; a conclusão reside na indicação, pelo demandante, do direito que ele alega ter. Assim, uma demanda de condenação a ressarcir danos incluirá (a) a invocação da norma segundo a qual todo aquele que culposamente causa dano a outrem deve ressarcir (CC, art. 159), (b) a descrição de uma conduta culposa do réu e dos danos causados ao autor e (c) a conclusão de que ele é devedor a este pelo valor dos danos causados. A ideia de um silogismo na sentença está muito desgastada em doutrina e sabe-se que dificilmente um juiz ou um autor observa os rigores lógicos desse caminho, ao sentenciar ou ao postular. Mas, uma vez elaborada a sentença ou a petição inicial, a análise silogística é possível e muito útil’. 193
\end{abstract}

Por isso, podemos afirmar que a causa de pedir é formada apenas pela alegação de fatos jurígenos (fatos criadores de direito), também chamados de fatos essenciais ou primários, entendidos como aqueles capazes de produzir os efeitos jurídicos pleiteados no

${ }^{191}$ Cf. Eduardo Couture, Introducción al estúdio del proceso civil, p. 64; Osly da Silva Ferreira Neto, Ações tributárias coletivas, 2013, pp. 173-174.

192 Exatamente nessa linha de raciocínio, Bedaque sustenta a necessidade de recurso à norma de direito material aplicável para a "seleção dos fatos da vida, com base em que se pretende determinada consequência jurídica". Cf. Bedaque, "Os elementos objetivos da demanda à luz do contraditório", Causa de pedir e pedido no processo civil, p. 32.

${ }^{193}$ Cf. Dinamarco, Instituições de direito processual civil, vol. II, item 451. 
petitum, exatamente por se adequarem à moldura abstrata de determinada norma jurídica que serve de fundamento da demanda. ${ }^{194}$

Estes fatos essenciais, portanto, vão variar a depender das normas aplicáveis ao caso, aptas a propiciarem os efeitos pleiteados pelo demandante, e deverão ser identificados e separados das demais alegações presentes na linguagem que constitui o ato processual (demanda).

Todos os demais fatos (rectius alegações de fato) serão pautados como fatos meramente secundários, pois incapazes de justificar a produção dos efeitos pleiteados no pedido. ${ }^{195}$ Os fatos secundários, como visto acima, podem ser até relevantes, por terem relação com aspectos probatórios, provas indiretas e presunções processuais, ou mesmo com aspectos de ordem processual, contudo, jamais integrarão a causa de pedir, por serem imprestáveis para a individualização da demanda.

\subsection{CORRELAÇÃO E FATOS SECUNDÁRIOS}

Exatamente por não configurarem causa de pedir, é desde logo importante esclarecer que, ao contrário dos fatos primários, os fatos secundários não se submetem às regras da inércia, da estabilização da demanda e da congruência.

Os fatos secundários podem, por consequência, serem alegados em qualquer momento, sem preclusão, podendo inclusive serem conhecidos ex officio pelo julgador, com a ressalva, aplicável a qualquer debate processual, do necessário respeito ao princípio do contraditório.

Não concordamos, por este motivo, com as posições de Liebman e Buoncristiani, segundo as quais o juiz estaria impedido de conhecer de ofício de fatos secundários por

\footnotetext{
${ }^{194}$ A respeito da moldura da norma jurídica (leis), Junqueira de Azevedo sustenta que a referência a fatos é "feita através de palavras e proposições aptas a agrupar um certo número de situações semelhantes; a esse tipo de referência se pode dar o nome de suporte fático". (Conceito, identificação e conexão de causas no direito processual civil, p. 20).

195 Referindo-se aos direitos heterodeterminados, Gian Franco Ricci afirma que estes apenas podem ser identificados pelo seu "fatto generatore". (L'allegazione dei fatti nel nuovo processo civile", Rivista Trimestrale di Diritto e Procedura Civile, set. 1992., n. 3., p. 852). No mesmo sentido, Cerino Canova, "La domanda giudiziale ed il suo conteunto", Commentario del codice di procedura civile, p. 186 e ss; Proto Pisani, Note in tema di nullità dell'atto di citazione e di effetti sostanziali e processuali della domanda giudiziale, p. 665 s.; Mandrioli, Riflessioni in tema di $\langle$ petitum $>>$ e di $<$ causa pretendi $>>$, p. 475, Consolo, Oggetto del giudicato e principio dispositivo, p. 238.
} 
força da incidência da regra do impedimento de utilização de seu conhecimento privado. ${ }^{196}$ E isto porque conhecimento privado é aquele que não se pauta nos elementos cognitivos trazidos aos julgados (alegações e provas), e estes fatos secundários, mesmo quando não alegados, podem ser conhecidos pelo juiz a partir da análise de vários elementos probatórios constantes dos autos (documento, perícia, testemunho, etc.), sem que seja necessário recorrer a nenhum conhecimento privado do julgador. A este respeito, Heitor Sica ressalta que:

"o que se veda é o uso de conhecimentos específicos sobre o litígio adquiridos pelo juiz fora do
processo, em face do (muito provável) comprometimento de sua parcialidade (...). Se o
convencimento judicial é formado dos elementos constantes dos autos, trazidos mesmo sem a
alegação direta e específica das partes, tem-se aqui o fenômeno parecido com aquele do exercício
dos poderes instutórios judiciais, como leciona Frederich Stein, em sua famosa obra El
conocimiento privado del juez". ${ }^{197}$

Esta afirmação ganha mais força quando observamos que variados fatos secundários têm relevância para questões de ordem pública, a respeito das quais a ordem positiva autoriza expressamente o conhecimento ex officio (CPC, art. 267, § $3^{\circ}$ ), tal como ocorre ao tratarmos de fato secundário relativo a normas de competência absoluta (CPC, art. 113) ou mesmo de fatos secundários relevantes para a admissibilidade de determinado ato ou procedimento legal.

Pode o juiz, pela análise do contrato, reconhecer ex officio os fatos que caracterizam uma relação de consumo, determinando a partir daí a nulidade da eleição de foro (CPC, art. 112, par. único) ou mesmo a incompetência de juízo cível comum, em favor de vara especializada na matéria. Do mesmo modo, reconhecer o fato secundário de a demanda, entre outros casos, não pautar-se em "arrendamento ou parceria rural", impedindo o seguimento do procedimento comum sumário (CPC, art. 275, II). Pode conhecer de ofício a existência de coisa julgada material, decretando a extinção do processo sem julgamento de mérito (CPC, art. 267, $\S 3^{\circ}$ ). Entre outros casos.

Os fatos secundários, portanto, sejam eles relevantes para a prova ou sejam eles relevantes para o processo, podem ser conhecidos pelo juiz, ainda que não alegados na demanda ou em ato posterior, exatamente porque não integram o objeto litigioso do 29.

${ }^{196}$ Cf. Liebman, Fondamento del principio dispositivo, p. 562; e Buoncristiani, L'allegazione dei fatti, p.

${ }^{197}$ Cf. Heitor Sica, O direito de defesa no processo civil, p. 151 
processo, não sofrendo as limitações impostas pela inércia e correlação. Ressalvamos, apenas, que o conhecimento de tais fatos deve ser acompanhado, sempre que possível, do respeito ao contraditório.

\subsection{CAUSA DE PEDIR REMOTA: ENTRE SUBSTANCIAÇÃO E INDIVIDUALIZAÇÃO}

Vimos no item precedente que $(i)$ a norma jurídica aplicável à causa, em sua fattispecie, prescreve um conjunto de fatos sociais que, uma vez verificados, devem desencadear os efeitos previstos no seu consequente (sanctio juris) e que (ii) compõem a causa de pedir, deste modo, não todos os fatos alegados ou alegáveis na petição inicial, mas apenas aqueles (segundo a substanciação, efetivamente alegados) que se subsumiriam à hipótese legal da norma jurídica aplicável, e cujos efeitos são pleiteados mediante o petitum.

Esta circunstância decorre da estrutura do ordenamento jurídico, do seu modo-deser, e é um problema de teoria do direito, e não de direito positivo. O que, verdadeiramente, pode variar conforme o direito positivo é consideração de que a causa de pedir compreenda apenas os fatos minuciosamente enunciados ou que a causa de pedir englobe mesmo os fatos não pormenorizados, embora relativos à categoria jurídica invocada na demanda. ${ }^{198}$

Assim, um determinado ordenamento jurídico pode prescrever que a causa de pedir contenha todos os fatos que poderiam ser submetidos à mesma "situação jurídica", poderiam vir a ser alegados no curso do processo, sem que seu objeto litigioso seja alterado. Fazendo-o, entendemos que o ordenamento jurídico teria acolhido a teoria da individualização.

Por exemplo, se o autor na petição inicial de "ação de domínio" (reivindicatória) alega como fato jurígeno de sua "propriedade" (situação jurídica) a compra e venda firmada na data tal entre tais partes, e a sentença é julgada improcedente, negando-lhe o pedido ao argumento da invalidade do contrato, o objeto do processo não deverá ter abarcado apenas esta causa de pedir, mas também todas as outras não decididas e não

\footnotetext{
${ }^{198}$ A respeito da perspectiva ainda mais distinta que o direito positivo pode conceder quanto ao que deve constar no ato de demandar, uma análise do sistema anglo-saxão é pertinente. Cf. Lewis A. Kaplan, "Implied causes of action" 8 Litigation 33, pp. 1981-1982.
} 
alegadas, impedindo que outra demanda seja admitida, com fundamento em causa de pedir não alegada ou não discutida, mas que trate da mesma situação jurídica de propriedade, tal qual a doação ou a usucapião.

Diferentemente, o ordenamento jurídico poderia determinar que o objeto litigioso do processo somente seria individualizado a partir dos fundamentos de fato efetivamente alegados e aplicáveis à hipótese (fattispecie) da norma pertinente ao julgamento do caso, i.e. cujos efeitos são demandados por meio do petitum. Fazendo-o teria optado pela teoria da substanciação.

Neste caso, o demandante teria o ônus de individualizar com precisão sua causa de pedir, alegando todos os fatos pertinentes para a caracterização da posição jurídica de vontade afirmada, ainda que trate de direitos absolutos (autodeterminados), de modo que o objeto do processo haveria de ser menos amplo, abarcando apenas aquilo que foi efetivamente alegado nas suas miudezas. ${ }^{199}$

Na hipótese de negativa deste direito, o mesmo pedido poderia ser formulado, em nova demanda, e pautando-se na mesma categoria jurídica (i.e. propriedade), desde que a causa de pedir fática alegada seja diferente (novo fato constitutivo do direito). Desse modo, uma ação reivindicatória tratando das mesmas partes e do mesmo bem, julgada improcedente por invalidade da compra e venda, poderia ser reformulada com fundamento em usucapião ou doação, tendo seu mérito analisado. Vejamos outro exemplo: se

\footnotetext{
199 O problema específico dos chamados direitos autodeterminados reside na circunstância de que seus antecedentes são caracterizados por preverem uma relação jurídica; o produto da incidência dos efeitos previstos por outra norma a determinados fatos. Enquanto nos direitos heterodeterminados, o fato relevante é um evento social regulado pelo direito, um crime, um acidente, uma enchente, nos direitos autodeterminados o fato relevante é representado pela circunstância de outros fatos haverem se subsumido a outra norma produzindo, em concreto, um determinado efeito jurídico. Por este motivo, nos direitos autodeterminados, há uma norma concreta (ou seus efeitos) como fato juridicamente relevante (fattispecie) que, por sua vez, já haveria de ser individualizada pelos fatos previstos na sua respectiva fattispecie. A questão relativa à substanciação, portanto, reside na circunstância de que, quando efeitos jurídicos são pedidos com base em direitos autodeterminados, seria necessário descrever, além da fattispecie da norma aplicável (apta a produzir os efeitos pretendidos), também a fattispecie da norma que se subsume à fattispecie da norma aplicável. Enquanto que na individualização, todos os fatos jurídicos aptos a produzirem o efeito previsto no antecedente da norma aplicável (e.g. todo e qualquer fato que poderia gerar o efeito jurídico propriedade) estariam tacitamente incluídos na causa de pedir fática. Vejamos um exemplo. Qual é a fattispecie da norma que prevê o direito do proprietário reaver a coisa que injustamente lhe foi tomada? Conforme o art. 1.228 do Código de Processo Civil, basta o fato de "ser proprietário". Ocorre que ser proprietário é um fato especial, diferente de outros. É um fato caracterizado pelos efeitos da incidência de uma norma a outros fatos, ou seja, o antecedente da norma do art. 1.228 prevê como "fato" o consequente de outras normas, daquelas que determinam os meios de aquisição da propriedade, tais como os artigos 1.227, 1.238, 1.248 e 1.267 do Código Civil. Assim é que, nos termos das citadas normas, tendo ocorrido um fato social apto a justificar a aquisição da propriedade (e.g. tradição, transcrição, usucapião, acessão), gera-se o efeito jurídico previsto: "ser proprietário". Ocorre que esse mesmo "ser proprietário", a despeito de previsto como efeito de uma norma, é a consequência jurídica (juris sanctio) de outra (CC, art. 1.228), que diz "dado "ser proprietário" dever ser "o poder de reaver a coisa em face de quem injustamente lhe tomou". A respeito das especificidades do direto de propriedade, cf. Alf Ross, Tû-Tû, p. 31.
} 
formulássemos pedido de anulação de negócio jurídico (CC, art. 171, I) ao argumento de que este foi assinado por relativamente incapaz, porque menor de 18 anos sem assistência $\left(\mathrm{CC}\right.$, art. $\left.4^{\mathrm{a}}, \mathrm{I}\right)$, teríamos uma demanda distinta de outra, na qual formularíamos o mesmo pedido de anulação, fundado no mesmo artigo de lei (CC, art. 171, I) e no mesmo contrato com as mesmas partes, embora a nova alegação fosse no sentido de que a incapacidade relativa decorreria do uso reiterado de tóxicos, apto a reduzir as capacidades de discernimento do agente (CC, art. $\left.4^{\circ}, \mathrm{II}\right)$. E assim por diante.

Efetivamente, as diferentes perspectivas fazem variar a relevância que se dá aos fatos, ou melhor, ao conteúdo da causa de pedir, que num caso seria constituído por tudo que poderia ser alegado entre as partes em relação a uma mesma situação jurídica (teoria da individualização) e noutro caso seria restrito aos fatos pormenorizadamente alegados na petição inicial (teoria da substanciação). Mas qual teoria teria sido aceita pelo direito positivo brasileiro?

A necessidade de narrativa de fatos como causa de pedir já restava muito clara na redação do Código de Processo Civil de 1939, que determinava em seu artigo 158 que a ação terá início por petição escrita onde serão indicados: "III - o fato e os fundamentos jurídicos do pedido, expostos com clareza e precisão, de maneira que o réu possa preparar a defesa". A redação do vigente Código, especialmente do artigo 282, teve como clara referência a lei pretérita, embora esta, por sua vez, tenha tomado como referência os códigos estatuais e, especialmente, o Regulamento 737 de 1850, que já tratava do tema com certa precisão, in verbis:

\footnotetext{
“Art. 66. A acção ordinaria será iniciada por uma simples petição que deve conter: $\S 1^{\circ} \mathrm{O}$ nome do autor e do réo. $\S 2^{\circ} \mathrm{O}$ contrato, transacção ou facto dos quaes resultar, segundo o Código, o direito do autor e a obrigação do réo. $\S 3^{\circ} \mathrm{O}$ pedido com todas as especificações e estimativa do valor quando não fôr determinado (...)".
}

Ao contrário do que ocorreu na Alemanha e na Itália, no Brasil reinou com relativa harmonia na doutrina a ideia pela qual nossa ordem processual acolheu integralmente a teoria da substanciação. ${ }^{200}$ Entenderam os processualistas que, exigindo o Código a menção expressa aos fatos e aos fundamentos jurídicos do pedido, na petição inicial, seria evidente a opção do legislador pela teoria da substanciação. Posição esta que

\footnotetext{
${ }^{200}$ Cf. Pontes de Miranda, Comentários ao Código de Processo Civil, v.2, 1941, p. 131, e Comentários ao Código de Processo Civil, t. 4, 1974, p. 17; Moacyr Amaral Santos, Primeiras linhas de direito processual civil, v.1, 1997, p. 164; Arruda Alvim, Direito processual civil, v.2, p. 47.
} 
valeria tanto para as demandas fundadas em direitos pessoais quanto para as demandas fundadas em direitos reais. ${ }^{201}$

Nossa jurisprudência, seguindo as referidas posições doutrinárias, do mesmo modo realça a opção legislativa pela teoria da substanciação: “o provimento judicial está adstrito não só ao pedido formulado pela parte na inicial, mas também à causa de pedir, que, de acordo com a teoria da substanciação, é delimitada pelos fatos narrados na petição inicial". 202

A divergência coube a Botelho de Mesquita. O processualista, cuidando do Código de 1939, ressalta que o fato de o Código mencionar a exigência da narrativa dos fatos na petição inicial, como causa de pedir, não excluiria a possibilidade de acatamento da teoria da individualização. Sustenta que a lei também prescreveria a exigência de inserção dos fundamentos jurídicos do pedido, que não seriam “nem a norma da lei, nem tampouco as deduções jurídicas, salvo quando, excepcionalmente, a norma legal sirva, à falta de outros elementos, para individuar o direito particular feito a valer pelo autor no processo". O autor assim prossegue afirmando que o "fundamento jurídico do pedido" deveria ser compreendido como a relação jurídica controvertida e o direito dela decorrente, de modo que o Código não teria, por estes motivos, se filiado à corrente da substanciação. Pelo contrário, teria adotado uma "posição de grande equilíbrio entre ambas as correntes conflitantes, dando importância tanto aos fatos constitutivos quanto aos elementos de direito, na medida em que sirvam para individuar a pretensão do autor". ${ }^{203}$

Assim como Botelho de Mesquita, Milton Paulo de Carvalho ${ }^{204}$ e Ovídio Baptista da Silva ${ }^{205}$ aderiram ao pensamento dissonante. Os autores entenderam que o Código teria sido desenhado a partir das duas teorias, dando relevância tanto aos fatos descritos quanto ao direito invocado. Este segundo, especialmente, afirma a existência de uma atenuação à teoria da substanciação, na medida em que a lei exigiria apenas a narrativa dos chamados "fatos essenciais" como fundamento do pedido.

Cruz e Tucci, seguindo a mesma linha, acrescenta que não seria lícito afirmar, com base apenas na redação do artigo 282 do CPC que nosso ordenamento teria adotado a teoria da substanciação. E isto porque a redação do citado dispositivo é muito similar à redação do art. 163, 4, do CPC italiano e do $§ 253$, 2, da ZPO alemã, embora naqueles

${ }^{201}$ Cf. Humberto Theodoro Jr., Curso de direito processual civil, v.1, 32 ed., 2000, p. 314.

${ }^{202}$ STJ, $5^{a}$ t., RESP n. ${ }^{\circ} 1351484$ RJ 2010/0168056-2, Relator: Ministro Gilson Dipp, j. 20/03/2012.

${ }^{203}$ Cf. Botelho de Mesquita, "A causa pretendi nas ações reivindicatórias", Revista de direito processual civil, p. 197.

${ }^{204}$ Cf. Milton Paulo de Carvalho, O pedido no processo civil, p. 92.

${ }^{205}$ Cf. Ovídio Baptista da Silva, Sentença e coisa julgada, 1979, p. 166. 
países tal redação jamais tenha sido aceita como argumento inexorável pela adoção da referida teoria. Nesse sentido, afirma que a análise isolada de apenas um dispositivo normativo não seria adequada para avaliar a opção técnica de todo o sistema, exigindo assim o desenvolvimento de uma interpretação lógico-sistemática. ${ }^{206}$

O processualista inicia sua análise avaliando o princípio da eventualidade, constituído pelos artigos 264, 474 e 517 do Código de Processo Civil e afirmando que se exigiria no processo civil brasileiro, ao contrário do que ocorreria na Itália e Alemanha, que as partes apresentassem, em um mesmo momento, todos os "meios de ataque e de defesa". Haveria, assim, inicialmente, o ônus do demandante em formular todos os seus pedidos e causas de pedir até o momento da citação, depois do qual qualquer alteração somente ocorreria com anuência do demandado. E depois do saneamento do processo, nem mesmo com tal anuência seria viável a alteração dos elementos da demanda (CPC, art. 264, $\S$ único). A inovação, inclusive, seria vedada em sede recursal, por força do artigo 517 do Código de Processo Civil, o qual autorizaria apenas a alegação de novas questões (objeto cognitivo do processo), não de novos pedidos ou de novas causas de pedir (objeto litigioso do processo).

Por fim, o tratamento da chamada eficácia preclusiva da coisa julgada, nos termos do artigo 474 do Código, também nos remeteria à eventualidade: "passada em julgado a sentença de mérito, reputar-se-ão deduzidas e repelidas todas as alegações e defesas, que a parte poderia opor assim ao acolhimento como à rejeição do pedido". Cruz e Tucci, nesse sentido, não a partir da singular análise do artigo 282, mas de um conjunto de normas, conclui que o sistema rígido de preclusões - imposto especificamente por nosso direito positivo - constituiria "pressuposto da teoria da substanciação", na medida em que exigiria, na petição inicial, a exposição simultânea dos fatos que fariam valer o direito deduzido (causa pretendi remota) e "do enquadramento da situação concreta, narrada in status assertionis, à previsão abstrata, contida no ordenamento de direito positivo, e do qual decorre a juridicidade daquela (causa pretendi próxima)". ${ }^{207}$

A consequência desse sistema seria a de que a alteração de um fato concreto, narrado como causa de pedir remota, alteraria o objeto litigioso do processo (i.e. configuraria outra demanda) ainda que mantivéssemos o mesmo petitum e arguíssemos a mesma situação jurídica como fundamento (e.g. nulidade do contrato, direito de servidão, direito de propriedade, etc.).

\footnotetext{
${ }^{206}$ Cf. Cruz e Tucci, A causa pretendi no processo civil, $2^{\mathrm{a}}$ ed., p. 148.
}

${ }^{207}$ Cf. Cruz e Tucci, A causa pretendi no processo civil, $2^{\mathrm{a}}$ ed., p. 151. 
No presente trabalho, embora não seja possível ignorar relevantes fundamentos a sustentarem ambas as posições, partiremos da premissa de que o direito brasileiro - assim como declarado pela jurisprudência e pela doutrina majoritária - aderiu à teoria da substanciação, de modo a incluir na causa de pedir fática todas as circunstâncias pormenorizadas que justificariam o nascimento do direito invocado e que, uma vez alteradas, implicariam alteração do objeto litigioso do processo. ${ }^{208}$

\subsection{INSUFICIÊNCIA DA NORMA DE DIREITO MATERIAL: AINDA IDENTIFICANDO O FATO} ESSENCIAL

Do que se expôs até o momento, os fatos essenciais serão aqueles que efetivamente se enquadram no modelo abstrato previsto pela norma de direito material relevante para o caso (apta a produzir os efeitos jurídicos pretendidos pelo pedido), devendo serem narrados na suas miudezas (substanciação). O pedido, desse modo, permite-nos identificar a norma apta a produzir os efeitos desejados e esta norma, por sua vez, a partir de seu antecedente (moldura), nos fornece uma referência concreta para a delimitação dos fatos essenciais.

Até aí, tudo parece claro: para sabermos o que é essencial, basta nos dirigirmos à norma aplicável e analisarmos as hipóteses de fato que esta mesma norma prevê como relevantes. Identificadas estas, podemos nos dirigir à demanda e separar o "joio do trigo". O problema, no entanto, surge quando esta identificação encontra a realidade, muitas vezes marcada por um emaranhado de alegações, muitas delas inúteis, muitas úteis para a prova e para o processo, e poucas úteis para delimitar seu objeto litigioso.

Mais do que isso, as referências que a norma jurídica às vezes nos fornece (hipóteses de fato ou fattispecie), ante à sua abstração, são muito limitadas. Não se sabe

\footnotetext{
${ }^{208}$ Entendemos que, do ponto de vista de política legislativa, é interessante permitir que o instrumento estatal de resolução de controvérsias abarque, em seu objeto, a maior parcela da lide possível, valorizando o escopo social do processo. A teoria da individualização, especialmente nos casos dos direitos autodeterminados, atenderia melhor a este objetivo, pois passaria a permitir - após a coisa julgada - a imunização de uma gama maior de situação (fatos alegados e fatos alegáveis). No entanto, pensamos que a sua adoção pressuporia uma maior clareza no direito, de modo que viabilizar o efetivo contraditório, é dizer, para que esse pensamento possa valer, deve ser sempre certa, quanto ao demandado, a expectativa de que este teria de se defender, não apenas quanto aos fatos jurígenos alegados, mas também quanto a todos os demais fatos que poderiam ser alegados e que igualmente seriam aptos a gerar as consequências jurídicas pleiteadas. Sem esta certeza, pensamos que a adoção da teoria da individualização surgiriam como um mal à efetividade do processo.
} 
qual é o grau de detalhe exigido na descrição de fatos para que determinados efeitos jurídicos possam ser produzidos. Pela sua natureza abstrata, os enunciados prescritivos do direito são feitos a partir de generalizações que reduzem os episódios a vida a um núcleo essencial, retirando qualidades específicas que concedem unicidade a cada um dos eventos. $^{209}$

Um fato é jurídico porque tomamos como referência um antecedente de uma norma jurídica, que o qualifica, mas a noção de "fato" é equívoca, pois $(i)$ a moldura da norma jurídica não prevê fatos, mas hipóteses (abstrações) de fato (fattispecie); (ii) essa mesma moldura admite diferentes interpretações, fazendo variar a abrangência dos fatos por ela qualificáveis; e (iii) a moldura da norma jurídica não nos fornece indicativos para diferenciarmos dois fatos concretos, distintos, mas que em relação às mesmas partes produzem os mesmos efeitos. ${ }^{210}$

Fixada a premissa de que apenas as alegações de fato (causa de pedir remota) são úteis para a delimitação do objeto litigioso do processo, resta saber qual é a exigência de delimitação dos fatos para a individualização de uma demanda, i.e. qual é a miudeza de detalhes necessária para individualizar o objeto litigioso de um processo.

Nosso sistema, tendo aderido à teoria da substanciação, sabidamente exige uma maior intensidade na descrição dos fatos, exige a narrativa de uma conduta concreta apta a desencadear os efeitos de uma dada norma jurídica, não sendo suficiente a mera indicação de uma categoria jurídica como "conduta negligente do réu ao guiar automóvel" ou mesmo "nulidade relativa do contrato".

Assim, no primeiro caso, o objeto litigioso seria designado por uma específica conduta negligente do réu, tal como dirigir alcoolizado ou na contramão, excluindo-se do objeto litigioso do processo outras condutas - igualmente negligentes - mas não enunciadas como causa de pedir. Do mesmo modo, no segundo caso, o objeto litigioso seria delimitado pela "incapacidade relativa de um dos contratantes" ou mesmo pelo "erro de uma das partes", excluindo-se do objeto litigioso eventuais fatos que, embora

\footnotetext{
${ }^{209}$ Cf. Osly da Silva Ferreira Neto, Ações tributárias coletivas, 2013, p. 39; e Bruno Silveira de Oliveira, Conexidade e efetividade processual, 2007, pp. 24-26.

${ }^{210}$ Esta questão é tratada por Passo Cabral, ao afirmar que "uma mesma qualificação jurídica pode derivar de diversos fatos; ao imputar negligência de um motorista causador de um acidente de trânsito, podem ser alegados vários comportamentos concretos que levem àquela configuração (...). E sobre cada um destes aspectos pode ser ampliada a argumentação das partes e produzidas provas a respeito". O autor, no entanto, distancia-se do direito positivo, ao concluir que "em se verificando que o litigante optou por argumentar alegando várias condutas concretas que poderiam conformar-se ao conceito de negligência, torna-se mais claro que aquela determinada questão (a negligência) foi debatida com exaustão. Assim, outras condutas concretas não alegadas no processo deverão ser consideradas argumentos preclusos (...)" (Antonio do Passo Cabral, Coisa julgada e preclusões dinâmicas, 2013, pp. 438-439).
} 
igualmente aptos a justificarem a invalidade do contrato, não teriam sido incluídos textualmente na causa de pedir, como e.g. estado de perigo ou lesão (CC, art. 171).

Até aí, não há problemas, e a doutrina como vimos no item 3.13 é tranquila em aderir a estas afirmações. O problema é que, mesmo quando se descreve uma dada conduta ou fato concreto na causa de pedir, há a possibilidade $(i)$ desta descrição ser realizada em diferentes intensidades; e (ii) de o objeto litigioso do processo exigir mais ou menos detalhes para se configurar. ${ }^{211}$

Nos termos do artigo 282, III, do Código de Processo Civil, precisamos saber qual é a descrição mínima de "o fato e os fundamentos jurídicos do pedido" necessária para que se possa afirmar que a demanda contém uma indicação válida de causa de pedir. Além disso, precisamos saber o nível de detalhe da descrição de fato que deve ser considerado na delimitação do objeto litigioso da demanda, de modo a influenciar institutos como a estabilização da demanda, a correlação, a litispendência e a coisa julgada.

Os problemas são distintos, mas, conforme veremos, a lei parece - à luz do contraditório - colocar no mesmo patamar estas duas exigências distintas (i) pormenorização para fins de validade da petição inicial; e (ii) pormenorização para fins de individualização do objeto litigioso do processo.

É possível que a petição inicial seja muito mais minuciosa que o necessário para sua validade e que estas informações adicionais não sejam úteis ou relevantes para a delimitação do objeto litigioso do processo, e.g. em ação de acidente de trânsito fundada na imprudência, o autor alega que o réu conduzia veículo a $122 \mathrm{~km} / \mathrm{h}$, em local onde o limite era apenas $60 \mathrm{~km} / \mathrm{h}$.

Neste exemplo, não apenas indicou-se que na rua tal e na data tal o automóvel foi conduzido em excesso de velocidade e que isto caracteriza imprudência no trânsito que, por sua vez, é ato ilícito apto a justificar o dever de indenizar previsto pelo artigo 927 do Código Civil (fato concreto e individualizado), mas mensurou-se este fato com uma descrição minuciosa do valor do excesso de velocidade $(122 \mathrm{~km} / \mathrm{h})$.

A questão é, este valor é exigível na petição inicial, sob pena de inépcia? E mais, este valor, uma vez aportado na petição inicial, passa a integrar o conteúdo da causa de

\footnotetext{
${ }^{211}$ Passo Cabral critica a divisão entre fatos principais e acessórios, afirmando que estes representariam um "fracasso histórico" decorrente de um "ranço pandectístico que buscava definir e classificar, quase que à moda das ciências naturais, todos os conceitos do processo, ávidos por afirmar seu caráter científico. Mesmo o menor dos fenômenos deveria ser 'matematicamente' separado dos demais. Ora, não se tinha a consciência de que as ciências humanas não trabalham com precisão cartesiana; tampouco se compreendia que conteúdos argumentativos complexos e entrelaçados como estes não poderiam sofrer rupturas e segregações uns dos outros"(Antonio do Passo Cabral, Coisa julgada e preclusões dinâmicas, 2013, p. 428).
} 
pedir fática e do objeto litigioso do processo, de modo que eventual alteração no curso do processo seria inviável e que eventual sentença que declare a mesma imprudência, mas por outro valor de excesso de velocidade seria inválida (ofensa à correlação)?

O mesmo problema ocorreria se o preciosismo de detalhes ocorresse não com o valor da velocidade, mas com o horário do citado acidente. Suponhamos que a inicial descrevesse que a colisão teria ocorrido às 18:09 h de 24 de abril de 2013 e que, no curso do processo, fosse averiguado por meio das provas que o evento ocorreu às 19:01 h ou mesmo que a inicial teria se equivocado quanto à data, e que o evento teria ocorrido no dia 25 e não no dia 24 de abril de 2013. Assim questionamos: teria ocorrido alteração no objeto litigioso do processo?

A resposta parece ser negativa, mas, de fato, o direito processual não elenca critérios para delimitar qual é a pormenorização dos fatos necessária à validade da petição inicial e apta a configurar o objeto litigioso do processo. Conforme demonstraremos, somente a partir das circunstâncias da relação de direito material e dos parâmetros exigidos para que, naquele caso específico, o contraditório possa ser exercido plenamente, poderemos chegar a uma resposta adequada. ${ }^{212}$

\subsection{IURA NOVIT CURIA E RELATIVIDADE DO FATO ESSENCIAL}

O problema em se delimitar os fatos essenciais - que até agora já se mostrou suficientemente complexo - não se restringe ao enredamento e às minucias da realidade, tal como demonstrado acima. Há mais a cogitar.

Ainda que estas circunstâncias fossem ignoradas, haveríamos de admitir outro elemento complicador: a possibilidade de o juiz se valer de normas distintas daquelas enunciadas na demanda para efetuar o julgamento da causa, com fundamento no iura novit curia, fazendo variar os fatos essenciais a partir da variação das normas jurídicas aplicáveis ao caso.

\footnotetext{
${ }^{212}$ Athos Gusmão Carneiro apresenta caso peculiar, no qual, em ação declaratória de paternidade, após a estabilização do objeto litigioso do processo, o autor pretende trazer documento não antes apresentado que demonstraria que seu nascimento teria ocorrido 2 (dois) anos antes da data narrada na inicial, de modo a fazer coincidir com a data da possível concepção. O parecerista demonstra que a concepção seria fato essencial (fato simples) e que sua alteração importaria na alteração do objeto litigioso, o que seria vedado pela estabilização da demanda. (Cf. Athos Gusmão Carneiro, "A causa de pedir nas ações de investigação de paternidade", RePro 57, p. 227).
} 
Admitida a premissa de que os fatos essenciais se diferenciam dos demais por estarem inseridos na moldura da norma jurídica apta a produzir os efeitos pleiteados no pedido, resta clara a primeira necessidade para a sua detecção: o apontamento da norma jurídica aplicável.

Sem saber qual norma se aplica ao caso, não é possível identificar uma fattispecie apta a fornecer um critério objetivo, que permita a segregação entre fatos essenciais (primários) e fatos não essenciais (secundários).

Assim pensemos numa ação de reparação de danos. Um demandante alega que locou um automóvel de determinada empresa (locadora) e, em função de grave defeito no freio (inquestionável), que não teria recebido manutenção adequada, sofreu um acidente que lhe gerou prejuízos materiais de $\mathrm{R} \$ 10.000,00$ (dez mil reais). Assim, formula pedido condenatório ao pagamento da quantia.

Nesta perspectiva, e podendo identificar-se uma relação de consumo, que admite a regra da responsabilidade civil objetiva (CDC, art. 14), podemos pressupor, ante a fattispecie normativa invocada, que os fatos que narram a culpa (i.e. ausência de manutenção adequada no freio) são fatos meramente secundários, e não fatos essenciais. Para os fins da norma citada, basta a alegação do dano (prejuízo) e do nexo causal (locação de carro com defeito no feito), não importando o fato de tal defeito decorrer, ou não, de conduta culposa (imprudência, negligência ou imperícia) da locadora.

Por outro lado, admitindo-se que o locatário seja uma empresa de sublocação de automóveis, afastando a incidência do Código de Defesa do Consumidor, a culpa do agente passa a figurar como fato essencial, por força da nova fattispecie normativa, pertinente às relações civis comuns (CC, art. 927). Esta, ao contrário da outra, exige a presença da culpa, ao lado do dano e do nexo causa para produzir a consequência jurídica: dever de indenizar.

Assim, para a mesma demanda, com as mesmas partes, os mesmos fatos descritos na petição inicial e o mesmo pedido, podemos configurar, a depender da norma jurídica aplicável, duas categorias distintas de fatos essenciais e, por consequência, dois objetos litigiosos distintos. Aplicável o Código de Defesa do Consumidor, os fatos que retratam a culpa são secundários (e não ingressam na causa de pedir), aplicável o Código Civil, os fatos que retratam a culpa passam a ser primários (ingressando na causa de pedir).

Tais circunstâncias têm grande relevância à luz do princípio do iura novit curia, e permitem a constatação de que, ao alterar a norma jurídica aplicável ao caso, o juiz não está autorizado a se valer de fatos não alegados pelas partes. Todavia, o juiz pode partir de fatos inicialmente tidos como "não essenciais" - que assim foram alegados pelo 
demandante - para permitir a incidência de uma norma não invocada, desde que não decida além, aquém ou diferentemente do que foi pleiteado. ${ }^{213}$

Esta circunstância mostra a relatividade da teoria do fato essencial. Efetivamente, podemos dizer que o juiz não está limitado pelo que o demandante considera causa de pedir, mas pelas alegações de fato do demandante que, a depender da concepção do juiz da causa a respeito das normas aplicáveis, podem ou não integrar a causa de pedir. Isto porque, as alegações de fato somente serão essenciais se se adequarem à fattispecie da norma usada pelo juiz ao decidir, não importando a causa de pedir jurídica ou o fundamento legal apontado na demanda.

Passo Cabral parece tratar de situação similar ao afirmar: "quando circunstâncias fáticas iguais forem subsumidas a normas diversas, pode ser que assumam características diferentes que modifiquem o seu papel na discussão, e assim possam reduzir ou reforçar a intensidade com que os litigantes empenham em debate-las". O autor cita o exemplo de demanda de reparação de danos movida em face do Estado, com fundamento na responsabilidade civil objetiva. "Se a culpa não atraiu o foco da discussão, ainda que o causador do fato danoso tenha sido considerado culpado, a questão não pode ter qualquer efeito preclusivo em posterior demanda ajuizada pelo Estado para exercer o regresso contra o servidor público". ${ }^{214}$

É importante deixar claro, no entanto, que este entendimento se pauta no contraditório e na ideia de que o demandado tem o ônus de se manifestar sobre os fatos efetivamente alegados, e não somente em relação aqueles que entende pertinentes ao julgamento, especialmente porque tem a ciência prévia da possibilidade de o juiz se valer do iura novit curia para julgar a causa.

213 Tratando do caso inverso, assim declarou o STJ: "O fundamento jurídico do pedido constitui somente uma proposta de enquadramento do fato ou ato à norma, não vinculando o juiz. Como consequência, não há de se falar em sentença extra petita pela condenação por responsabilidade objetiva, ainda que a demanda tenha sido proposta com base na responsabilidade aquiliana. (...) (STJ, $3^{\mathrm{a}}$ T., REsp 819.568/SP, Rel. Ministra Nancy Andrighi, j. 20/05/2010).

${ }^{214}$ Cf. Antonio do Passo Cabral, Coisa julgada e preclusões dinâmicas, 2013, pp. 438. 


\subsection{RELATIVIDADE DO FATO ESSENCIAL E CONGRUÊNCIA}

A relatividade do fato essencial expõe a necessidade de que a teoria do objeto litigioso do processo não seja tratada, de modo uniforme, para todos os âmbitos do processo civil, ao contrário da proposta original de Chiovenda.

Pode ocorrer de o objeto litigioso do processo (fatos essenciais), detectado à luz da descrição normativa contida na demanda, não coincidir com o objeto litigioso do processo, detectado à luz do silogismo da sentença proferida no mesmo caso, sem que tal descompasso importe em ofensa à exigência da correlação.

Isto ocorre, pois, para fins de correlação, e especialmente porque os fatos secundários são alegados pelo demandante (em respeito à inércia) e submetidos ao contraditório, é possível que um fato inicialmente nascido na demanda como secundário e, portanto, externo ao objeto litigioso do processo - passe a integrar o objeto litigioso do processo.

Basta, desse modo, que o juiz, considerando as mesmas partes, o mesmo pedido e as mesmas alegações de fato contidas na demanda, valha-se, para decidir, de norma jurídica distinta daquela indicada na petição inicial, tal como lhe autoriza o princípio do iura novit curia. Quando da verificação da coisa julgada, no entanto, valerá a identificação do objeto litigioso do processo, não existente quando da propositura da demanda, mas quando da prolação da sentença transitada em julgado.

Em princípio, os fatos essenciais para os fins da coisa julgada deverão ser aqueles contidos na sentença, enquanto que os fatos essenciais para os fins da litispendência, conexão ou continência deverão ser sempre aqueles relativos à proposta do demandante, em sua petição inicial.

Daí surge outra questão.

Supomos que, no exemplo tratado acima, a demanda tenha sido proposta com base no Código de Defesa do Consumidor, tendo o demandante indicado como fato essencial apenas o dano e o nexo causal, sem integrar a causa de pedir fática qualquer das alegações (secundárias) presentes na petição inicial relativamente à conduta culposa da locadora de veículos. No entanto, ao produzir a sentença, com base no iura novit curia, o juiz rejeitou a aplicação do CDC e julgou com base no art. 927 do Código Civil, tomando como premissa de seu julgamento aquelas alegações, inicialmente secundárias, relativas à culpa da prestadora de serviços. 
Nesse sentido, teremos no curso do processo um objeto litigioso que não inclui aos seus fatos essenciais nenhuma discussão a respeito da suposta conduta culposa da locadora. No entanto, o objeto litigioso do processo, a ser considerado após o trânsito em julgado, para os fins da eficácia negativa da coisa julgada material, terá conteúdo distinto, abarcando os fatos relativos à culpa e, portanto, impedindo a propositura de demanda diferente daquela que originou a sentença.

É dizer, caso nova demanda seja proposta com base no mesmo pedido e nas mesmas partes, mas com indicação da conduta culposa como causa de pedir (novo fato essencial), à luz das demandas, teríamos dois objetos litigiosos distintos, no primeiro e no segundo processo. No entanto, à luz da coisa julgada material, o objeto litigioso deste segundo processo seria idêntico aquele delimitado pela sentença prolatada, impedindo o julgamento de mérito da segunda demanda.

A partir dessa premissa, podemos afirmar que o objeto litigioso visto à luz da demanda nem sempre deve coincidir com o objeto litigioso visto à luz da sentença, de modo que, para fins de coisa julgada material, a referência a ser considerada especialmente quanto à identificação dos fatos essenciais - deverá estar presente na sentença, e não da demanda. ${ }^{215}$

\subsection{CAUSA DE PEDIR ATIVA E CAUSA DE PEDIR PASSIVA}

Além da distinção entre causa de pedir próxima e causa de pedir remota, é cogitada pela doutrina uma segunda distinção, entre causa de pedir ativa e causa de pedir passiva.

Enquanto a primeira representaria a alegação dos fatos constitutivos do direito pleiteado pelo demandante (fatos criadores do direito exigido), a segunda seria representada pela alegação dos fatos que justificariam a utilidade e a necessidade de intervenção jurisdicional (crise de cooperação) e, portanto, estaria relacionada a requisito de admissibilidade do julgamento de mérito, o interesse processual (CPC, arts. $3^{\circ}$ e $4^{\circ}$ ).

\footnotetext{
${ }^{215}$ A situação aqui tratada pressupõe a possibilidade de haver esta distinção mesmo que a sentença tenha sido produzida em respeito ao princípio da correlação. No entanto, seria mais facilmente concebível essa possibilidade nos casos de sentenças ultra ou extra petita, nas quais, por definição, o conteúdo da sentença não se espelharia no conteúdo da demanda. Em todos os casos, para fins de coisa julgada material, o conteúdo da sentença, e não o da demanda, deve ser levado em consideração.
} 
Ao menos do âmbito da Jurisdição Contenciosa, sem lide, não há necessidade/utilidade de instrumento estatal de resolução de controvérsias, de modo que a lei impõe a extinção prematura do processo, sem julgamento de mérito e sem aptidão para produzir coisa julgada material, toda vez que o processo surge sem um conflito a ser caracterizado (CPC, art. 267, III, 268, 467 e 485). ${ }^{216}$

A causa de pedir passiva, portanto, não se relaciona com o conteúdo do futuro ato de poder do Estado (mérito), a ser produzido pelo processo, na medida em que não tem aptidão em influenciá-lo, mas apenas de permitir, ou não, sua apreciação (admissibilidade). Por isso, diz respeito à necessidade, imposta pela técnica processual, de o demandante retratar uma situação caracterizada como patológica, (i) pela violação ou ameaça da violação a direito, quando falamos de crises de adimplemento e tutelas condenatórias, ou (ii) pela incerteza objetiva quanto à existência ou inexistência de uma relação jurídica, nas crises de certeza e tutelas declaratórias ou (iii) quanto a realização de determinado direito potestativo depende da atuação do juiz, nas crises de situação jurídica e tutelas constitutivas. ${ }^{217}$

${ }^{216}$ A Jurisdição pressupõe a existência de uma crise de cooperação, para que possa atuar plenamente. Vimos, inclusive, que a natureza da crise a ser solucionada pela tutela jurisdicional (crise de adimplemento, crise de situação jurídica ou crise de certeza) há de influir na natureza do provimento a ser emitido pelo Estado-juiz, determinando a espécie do pedido imediato a ser formulado pelo demandante (pedido condenatório, pedido constitutivo ou pedido declaratório). A existência de crise, com efeito, é pressuposto de admissibilidade do julgamento de mérito, ao passo que se mostra elemento caracterizador da utilidade e da necessidade de atuação da tutela jurisdicional, o quê nosso Código de Processo Civil logrou por chamar de interesse processual, uma das "condições da ação". O Estado-juiz movimenta-se por dispendiosa estrutura e a instauração e o prosseguimento do instrumento estatal de resolução de controvérsias implica na estipulação de deveres, contra o Estado, e de ônus processuais, especialmente em desfavor do demandado, que não escolhe por figurar naquela relação processual.

Desse modo, para ter direito a uma análise de seu pedido (e não somente um direito ao processo), não basta ao demandante afirmar ser titular de um direito subjetivo (tal qual o crédito), mas deve também justificar a necessidade e a utilidade da intervenção Jurisdicional. Vedada a autotutela, o demandante aduz à necessidade de intervenção de um terceiro imparcial (Jurisdição) ao relatar a ausência de cooperação das partes. Esta, por sua vez, torna impossível a obtenção do efeito jurídico pretendido sem a intervenção Jurisdicional. Cf. Bedaque, Efetividade do processo, p. 293-294.

${ }^{217} \mathrm{O}$ conceito de interesse processual é muito incerto na doutrina e na jurisprudência, não visando o presente trabalho a solucionar esta questão. Parte da doutrina entende que, não importando a espécie de demanda, interesse processual será algo ontologicamente distinto do mérito (Cf. Dinamarco, Execução Civil, $8^{\mathrm{a}}$ ed., 2002, pp. 412 e 413 e pp. 423-424). Outra parte da doutrina entende que nas demandas condenatórias e constitutivas, interesse processual e mérito seriam a mesma coisa (ou o interesse seria parte do mérito). (cf. Bedaque, Efetividade do processo e técnica processual, p. 307). Uma posição final, entende ainda que, mesmo nas declaratórias, interesse processual e mérito se confundiriam.(cf. Satta-Punzi, Diritto processuale civile, 13 ${ }^{\mathrm{a}}$ ed., pp. 138-139). Com base nestes problemas, outros autores adotaram solução pragmática, afirmando que o interesse processual só o é, se puder ser averiguado apenas a partir das alegações das partes, caso seja necessário avaliar por meio de provas a existência ou não de crie, estar-se-ia tratando de mérito (cf. Crisanto Mandrioli, Corso di diritto processuale civile, $2^{\mathrm{a}}$ ed., vol. 1, pp. 48-49). A despeito destes problemas, entendemos que - não importa a posição que seja adotada - qualquer alteração na narrativa destes fatos que descreveriam simplesmente a crise de cooperação (sejam eles distintos ou sejam eles iguais ou parcialmente iguais ao mérito) não devem implicar em alteração do objeto litigioso do processo. Isso será demonstrado a seguir. 
Assim, temos - em tese - duas categorias distintas de fatos: (i) os fatos que fazem surgir direitos e obrigações, que geram a criação a modificação ou a extinção de relações jurídicas e os que configuram sua existência ou inexistência, e (ii) os fatos que retratam o descumprimento destes direitos e obrigações (crise de adimplemento) ou a formação das crises de situação jurídica e certeza, fazendo incidir a norma secundária que trata da viabilidade da atuação jurisdicional acerca do mérito. ${ }^{218}$

Os primeiros criam ou fundamentam direito material alegado (direitos, deveres e obrigações), os segundos autorizam a utilização plena de um instrumento estatal de resolução de controvérsias (processo), ou melhor, permitem o seu julgamento de mérito. ${ }^{219}$ Por esta razão, segundo Dinamarco, falamos que a natureza da jurisdição é secundária: “conta o sistema jurídico com a própria prestação voluntária em primeiro lugar, dispondose a desencadear a atividade jurisdicional apenas o caso de descumprimento". Sua atuação completa (i.e. com análise de mérito) pressupõe seja ( $i$ ) necessária: "a todo aquele que tiver uma pretensão perante outrem não restará senão conformar-se ou pedir auxílio aos órgãos jurisdicionais, quando a outra parte se negar à prestação"; e (ii) útil: "o seu repetido exercício em casos concretos que as pessoas trazem, lamentando situações desfavoráveis e deduzindo pretensões, constitui indispensável fatos de paz social entre os membros da população e de estabilidade das instituições, do ordenamento jurídico e do próprio Estado". 220

Podemos, desse modo, distinguir os fatos que caracterizam a causa de pedir ativa dos fatos que caracterizam a causa de pedir passiva. Na primeira temos os fatos jurídicos que fazem surgir os direitos e as obrigações, cujos efeitos em concreto queremos ver produzidos com o pedido. A segunda, por sua vez, é formada pela descrição da crise, que faz nascer a necessidade de utilização do instrumento estatal de resolução de controvérsias

\footnotetext{
${ }^{218}$ Entendemos que as distinções devem ser analisar a partir da natureza das normas jurídicas aplicáveis aos fatos tratados (fatos que caracterizam causa de pedir ativa e fatos que caracterizam causa de pedir passiva). Temos aí duas classes normas; (i) as normas primárias ou endonormas que preveem o surgimento da relação jurídica, e que têm como pressuposto (antecedente normativo ou fattispecie) atos lícitos ou ilícitos aptos a fazerem surgir direitos e obrigações, e.g. o dever de pagar quantia em dinheiro, por força de contrato, e o dever de pagar reparação de danos em função de ato ilícito e (ii) as normas secundárias ou perinormas, que contém em seu antecedente a descrição de atos ilícitos (descumprimento de deveres nascidos a partir das normas primárias), e.g. descumprimento do dever de pagar o preço do contrato ou descumprimento do dever de indenizar a vítima (cf. Hans Kelsen, Teoria Geral do direito, 2003, pp. 256-258 e Paulo de Barros Carvalho, "A endonorma e a perinorma da doutrina egológica de Carlos Cossio", Teoria da norma tributária, 4. ed., p. 45-47). As normas primárias regulam a vida comum dos jurisdicionados, estabelecendo uma espécie de "fisiologia social", ao passo que as normas secundárias previnem ou remediam as ocorrências patológicas (tratando do direito processual). (cf. Liebman, Manuale di diritto processuale civile, vol. 1., p. 139).

${ }^{219} \mathrm{Cf}$. Bedaque, Efetividade do processo e técnica processual, pp. 309-317.

${ }^{220}$ Cf. Dinamarco, Execução Civil, 8a ed., 2002, pp. 412 e 413 e pp. 423-424.
} 
(interesse processual), e que será responsável por efetuar a individualização da norma abstrata e aplicação da sanção.

Falamos em duas categorias de fatos, pois teríamos duas classes de normas distintas a qualificar estes fatos: fatos qualificados como jurígenos pelas normas de direito material (das mais variadas) e fatos que autorizam o julgamento de mérito, estes regulados por normas processuais que tratam do interesse processual (CPC, art. $3^{\circ}$ e $4^{\circ}$ e 267$)$.

Até esse ponto, as distinções parecem claras. Ocorre que há um problema: a despeito de a causa de pedir ativa se diferenciar da passiva pela circunstância de possuir uma referência normativa diferente (a primeira material e a segunda processual), em muitos casos estas normas distintas qualificam como relevantes, simultaneamente, os mesmos fatos.

Especialmente quando tratamos de demandas constitutivas e condenatórias, é possível que parte dos fatos jurígenos (causa de pedir ativa) sejam relevantes para a caracterização do interesse processual, o que acaba por gerar grande confusão entre admissibilidade e mérito. ${ }^{221}$ Assim veremos a seguir.

\subsection{CAUSA DE PEDIR PASSIVA NAS DEMANDAS DECLARATÓRIAS}

Estabelecido que a causa de pedir passiva é constituída pela descrição dos fatos da realidade responsáveis por tornar útil e necessária a intervenção jurisdicional (crises de cooperação jurídica), resta esclarecer quais seriam estes fatos, nas diferentes sorte de crises surgidas no âmbito de direito material. Trataremos inicialmente das demandas declaratórias. ${ }^{222}$

O ordenamento jurídico - por diferentes motivos, e principalmente visando à economia processual - não autoriza que o instrumento estatal de resolução de controvérsias

${ }^{221}$ Cf. Bruno Silveira de Oliveira, Conexidade e efetividade processual, 2007, p. 62.

${ }^{222}$ Além de se exigir - para que haja necessidade de intervenção estatal - que a crise de certeza se estabeleça - não a qualquer sujeito - mas ao sujeito que deve ser submetido à eficácia ou ineficácia desta relação jurídica incerta, há de ser reconhecer que a crise de certeza terá contornos distintos, a depender da natureza da relação de direito material, que pode ser mais ou menos ampla. Assim a lição de Bruno Silveira de Oliveira: "Percebe-se, pois, que a caracterização da causa pretendi passiva nas demandas declaratórias varia conforme a eficácia do direito seja pessoal ou erga omnes. No primeiro caso, escusado dizer que o número das possíveis crises de certeza é limitado, ao contrário do que ocorre na segunda hipótese, em que a atitude de qualquer pessoa (que não, evidentemente, a do titular do direito) pode tornar a situação merecedora de tutela jurisdicional”. (Conexidade e efetividade processual, 2007, p. 67). 
prossiga ao julgamento de mérito, salvo se a intervenção jurisdicional se mostre útil e necessária, é dizer, capaz de transformar a realidade e conceder um bem da vida aos litigantes. Se não há crise e se o processo, em abstrato, não tem o condão, mesmo em tese, de conceder algum benefício (bem da vida) ao demandante, respeita-se o direito de ação, mas desautoriza-se análise meritória, destinando-o a um fim prematuro (extinção sem julgamento de mérito).

Nas demandas declaratórias, cabe ao demandante, não apenas demonstrar os fatos que constituem a relação jurídica que se quer declarar existente; ou caracterizam a inexistência de relação jurídica entre as partes, que se quer declarar inexistente (causa de pedir ativa), mas também alegar os fatos que caracterizam a crise jurídica, o não reconhecimento da relação jurídica existente ou inexistente, que determinará o objeto do processo (pedido mediato). Esta última categoria de fatos será caracterizada como causa de pedir passiva. 223

A crise de certeza é representada sempre pela descrição de uma conduta do sujeito que seria afetado $(i)$ pela relação jurídica que se pretende ver declarada existente na declaratória positiva ou (ii) pela inexistência da relação jurídica que se pretende obter na declaratória negativa. Deve representar um comportamento incompatível com a regulação jurídica em abstrato, tal qual exigir o cumprimento de obrigação inexistente ou se negar a reconhecer efeitos evidentes da relação jurídica que se afirma existente.

Aqui, diferentemente do que ocorrerá nas demandas constitutivas e declaratórias, os fatos que caracterizam a crise são ontologicamente distintos dos fatos que dão fundamento para a existência ou a inexistência da relação de direito material.

${ }^{223}$ Parte relevante da doutrina sustenta que os fatos a caracterizarem o interesse processual nas demandas constitutivas e condenatórias, que aqui tratamos sob a rubrica de causa de pedir passiva, não seriam ontologicamente distintos dos fatos (ou de parte dos fatos) relevantes para a produção dos efeitos demandados com o pedido (causa de pedir ativa). Isto ocorre, pois a crise de situação jurídica e a crise de adimplemento, que caracterizam o interesse processual nas demandas condenatórias e constitutivas, seriam fundamento, não apenas para a autorização de julgamento do mérito, mas também para o julgamento de procedência do pedido (cf. Bedaque Efetividade do processo e técnica processual, p. 307). Outros autores, tratando da técnica das condições da ação, afirmam que o interesse processual depende de averiguação apenas a partir das alegações das partes, caso seja necessário avaliar por meio de provas a existência ou não de crie, estar-se-ia tratando de mérito (cf. Crisanto Mandrioli, Corso di diritto processuale civile, $18^{\mathrm{a}}$ ed., vol. 1, pp. 54-55). Satta-Punzi, em posição extremada, afirmam que, mesmo nos casos de demandas declaratórias, não existiria distinções entre interesse processual e interesse substancial (cf. Diritto processuale civile, $13^{\mathrm{a}}$ ed., pp. 138-139).

Bedaque, a despeito de distinguir com clareza os fatos que caracterizam o interesse processual dos fatos que caracterizam o mérito nas demandadas declaratórias, sustenta que, nesse caso, a inadmissibilidade só deve ser declarada se puder ser identificada com base nas afirmações do demandante (teoria da asserção). Caso contrário, tendo o réu reconhecido a existência/inexistência da relação de direito material e apenas negado o interesse, a sentença deverá ser uma sentença de procedência, com a condenação dos autor nas verbas sucumbenciais (cf. Efetividade do processo e técnica processual, p. 318-322). 
Vejamos exemplo. Em demanda declaratória negativa movida contra empresa de telefonia que exige de consumidor o pagamento de aparelho de telefone que não foi contratado e nem recebido pelo consumidor, resta claro que $(i)$ a causa de pedir passiva é representada pela cobrança de quantia pautada em relação jurídica que não existe, i.e. pelo encaminhamento de cartas, ligações telefônicas ou mesmo negativação do consumidor no sistema de proteção ao crédito; (ii) a causa de pedir ativa, por sua vez, não se confunde com estes fatos, é representada pela inexistência de conduta das partes que se subsuma à lei, negócio jurídico ou ato ilícito a justificar a existência de qualquer relação obrigacional.

\subsection{CAUSA DE PEDIR PASSIVA NAS DEMANDAS CONSTITUTIVAS}

A causa de pedir passiva nas demandas constitutivas é representada pela descrição de crise caracterizada pela existência de pretensões resistidas quanto ao direito protestativo de criar, modificar ou extinguir uma relação jurídica. Determinado sujeito se apresenta como titular do direito de obter uma nova relação jurídica ou de modificar ou extinguir uma relação jurídica que já existe, ao passo que outro sujeito, também vinculado a esta relação jurídica, se recusa a autorizar/consentir com estes efeitos. ${ }^{224}$

Nas demandas constitutivas, serão causa de pedir ativa os fatos que configuram o direito potestativo do demandante em obter a criação, a modificação ou a extinção de uma situação jurídica. A causa de pedir passiva, por sua vez, será representada pelos fatos que configuram a resistência, a não cooperação do demandando para que tais efeitos sejam produzidos, tornando útil e necessária a intervenção jurisdicional.

Neste caso, estamos falando de fatos que se submetem a normas secundárias que tratam, não do surgimento do direito (no caso direito potestativo), mas da autorização ao

${ }^{224}$ As demandas constitutivas tem uma peculiaridade imposta pelo direito positivo, ao passo que se distinguem em duas categorias. Os casos que tratamos acima, cuidam das chamadas demandas constitutivas não-necessárias, é dizer, cuja pretensão pode ser satisfeita pela mera cooperação extrajudicial das partes. Ao lado destas, há ainda as demandas constitutivas necessárias que se caracterizam pelo impedimento legal a que os efeitos pretendidos (criação, modificação ou extinção de situação jurídica) sejam obtidos, senão pela atividade jurisdicional. Esta segunda categoria está normalmente relacionada a direitos indisponíveis ou direitos de incapazes, aos quais a lei concede maior grau de intervenção estatal e exige a atuação da Jurisdição (voluntária) como uma forma de fiscalização, para se verificar a regularidade da produção destes novos efeitos jurídicos. Com efeito, nas demandas constitutivas necessárias não haverá a necessidade de indicação de uma exata causa de pedir passiva, ao passo que não há crise de cooperação a justificar o interesse e a utilidade de intervenção do estado-juiz, mas uma simples previsão legal de obrigatoriedade. Cf. Bruno Silveira de Oliveira, Conexidade e efetividade processual, 2007, p. 65. 
demandante para que leve sua demanda ao julgamento de mérito e do correlato dever do Estado de julgar o pedido formulado (CPC, art. $3^{\circ}, 4^{\circ}$ e 267).

A doutrina, nesse sentido, refuta a possibilidade de se estabelecer clara distinção ao menos em determinados casos - entre a causa de pedir ativa e a causa de pedir passiva nas demandas constitutivas. Proto Pisani trata da questão, valendo-se do exemplo de demanda que visa à anulação de contrato, sob o argumento de que o erro, a coação ou qualquer causa de rescisão constituiriam fatos constitutivos do direito protestativo afirmado, de modo que a crise de situação jurídica seria fundamento do pedido. ${ }^{225}$ Bedaque do mesmo modo entende que a causa de pedir passiva nas demandas constitutivas seria idêntica à causa de pedir ativa, ao passo que a distinção entre mérito e interesse processual residiria, apenas, no momento em que o juiz teria condições de avaliar a ausência da condição da ação/mérito. Assim exemplifica:

\footnotetext{
"Pensemos em demanda visando à revisão de aluguel, proposta antes dos três anos previstos pela lei. Haveria diferença substancial entre a apuração desse fato na inicial, com a documentação juntada pelo autor, e aquela resultante da produção das provas no curso do processo? A situação é substancialmente igual a de quem pede a condenação ao pagamento de dívida ainda não vencida. (...) se a não subsunção for evidente não há necessidade de o processo prosseguir. Se não, somente após a produção de provas será possível chegar-se a alguma conclusão. No primeiro caso, fala-se em carência da ação por falta de interesse processual, visto que a inexistência da crise de direito material é perceptível a olho nu e o próprio autor reconhece isso. No segundo caso há improcedência, pois a conclusão sobre inexistência da crise depende da investigação aprofundada da relação material, descrita com outras características". 226
}

Desse modo, vemos que a causa de pedir passiva não é conceito de grande relevância quando tratamos de demandas constitutivas. Caso entendamos que esta seria representada pela mera afirmação de que existe uma resistência do demandado em produzir estes efeitos desejados amigavelmente, a ausência de "crise" seria relevante apenas nos casos em que fosse identificada liminarmente, com base na petição inicial. Caso tivéssemos que aguardar a resposta, apenas para constatar a ausência de crise, já teríamos condições de julgar o mérito.

Ora, se o réu reconhece o direito potestativo do autor em contestação, limitandose a dizer que nunca resistiu à sua pretensão de criar, modificar ou extinguir a relação jurídica em debate, a solução mais adequada seria proclamar desde logo estes efeitos em

${ }^{225}$ Cf. Proto Pisani, Lezioni di Diritto Processuale Civile, $5^{\mathrm{a}}$ ed., p. 314.

${ }^{226}$ Cf. Bedaque, Efetividade do processo e técnica processual, pp. 328-329 
sentença. A única peculiaridade seria a condenação do autor nas verbas de sucumbência, tendo em vista o "princípio da causalidade".

\subsection{CAUSA DE PEDIR PASSIVA NAS DEMANDAS CONDENATÓRIAS}

A doutrina diferencia os fatos que configuram o interesse processual (causa de pedir passiva), nas demandas condenatórias, dos fatos que configuram o mérito (causa de pedir ativa) a partir do ponto de referência da "exigibilidade". Enquanto não vencida/exigível a obrigação, não haveria necessidade concreta da Jurisdição, ausente portanto o direito a uma análise de mérito. Assim se manifesta Dinamarco: "Sem o requisito da atualidade, a vontade da lei não pode ser apreciada pelo juiz, pois ao suposto devedor não foi dada ainda a oportunidade de satisfazer voluntariamente a pretensão e o Estado". 227

Definimos exigibilidade como a faculdade do credor em exigir do devedor o cumprimento compulsório da prestação. O crédito pode existir antes, mas somente poderá ser exigido do devedor após preenchidos certos requisitos. Por isso, exigibilidade é "fato" regulado por normas de direito material, que pressupõem a distinção clássica (e como vimos relevante no desenvolvimento histórico da noção de objeto litigioso do processo) entre direito subjetivo e pretensão de direito material.

Nesse sentido, após afirmar a natureza substancial das normas que regem a exigibilidade, Dinamarco defende que, a despeito disso, certas normas de direito processual também a tomariam como referência, designando este fato (i.e. a exigibilidade) como relevante para a configuração do interesse processual nas demandas que visam a sanar crises de adimplemento (condenatória e executiva):

"São de direito processual as normas que põem a exigibilidade como requisito para executar, mas de direito substancial as que regem a ocorrência da própria exigibilidade. Constituem problemas de direito material, p.ex., o do momento do vencimento da obrigação (tempo), o do local em que deve ser cumprida (lugar), o da maneira como a obrigação deve ser cumprida (modo), o do bem apto a satisfazê-la (objeto), o da escolha do bem nas obrigações alternativas, o da regência diferenciada entre as obrigações portáveis e as quesíveis, o do vencimento antecipado das obrigações do falido ou dos créditos hipotecários, os relacionados com a recusa do credor a

${ }^{227}$ Cf. Dinamarco, Execução civil, $8^{\mathrm{a}}$ ed., 2002, p. 425. 
receber o bem oferecido pelo obrigado etc. O sistema processual recolhe as respostas já oferecidas pelo direito material a esses quesitos e as examina por sua própria óptica, definindo as conseqüências que elas devam projetar sobre o processo; cada uma dessas respostas repercute indiretamente na disciplina processual da execução forçada, ingressando nesse campo pelo canal do interesse de agir (infra, n. 1.425), o qual existirá ou não conforme as circunstâncias concretas de cada caso e segundo os preceitos jurídico-substanciais pertinentes", ${ }^{228}$

O direito subjetivo, relação de crédito e débito entre dois ou mais sujeitos, nasce sempre a partir de (i) ato ilícito ou de (ii) negócio jurídico (contrato, declaração unilateral de vontade) ou (iii) diretamente da lei. Ocorre que ser credor não significa, necessariamente, ter a faculdade de exigir o cumprimento compulsório da prestação devida. O próprio direito material especifica distinções entre estas categorias, afirmando hipóteses em que o crédito surge sem “exigibilidade”, seja porque este nunca será exigível, nos casos das chamadas obrigações naturais (e.g. dívida de jogo), seja porque a exigibilidade está sujeita a termo ou condição. Assim, não concordamos com aqueles que afirmam que a exigibilidade e o inadimplemento seriam requisitos para o direito de crédito. $^{229}$

A exigibilidade é um "estado de fato", produzido pela existência de uma obrigação acrescida do decurso de prazo (termo) ou acontecimento de evento (condição). O inadimplemento é uma conduta do devedor (omissiva ou comissiva): diante de obrigação exigível, o devedor se nega a realizar a conduta devida (obrigações de fazer, entregar coisa ou pagar quantia) ou realiza a conduta vedada (obrigações de não fazer).

Quando falamos, portanto, de demandas condenatórias (e executivas) o fato que faz nascer o direito (causa de pedir ativa) de exigir o cumprimento da obrigação é decorrente da soma de três fatores: (i) a existência de direito subjetivo; (ii) a ocorrência dos fatos que caracterizam sua exigibilidade (decurso de prazo, i.e "termo", ou realização de evento previsto, i.e. "condição"); e (iii) o inadimplemento (crise de cooperação). ${ }^{230} \mathrm{O}$

${ }^{228}$ Cf. Dinamarco, Instituições de direito processual civil, vol. IV, p. 173-174.

229 Proto Pisani, a partir da identificação dos escopos das normas relativas ao interesse processual, defende não existir interesse prático na definição de interesse de agir nas demandas condenatórias, argumentando que o inadimplemento seria elemento para se avaliar a existência ou não do direito substancial feito valer em juízo (cf. Lezioni di diritto processuale civile, $5^{\mathrm{a}}$ ed., p. 314).

${ }^{230}$ Embora não trate especificamente da questão, Liebman afirma que o interesse de agir nas demandas condenatórias seria caracterizado pela simples afirmação de um direito não satisfeito (non soddisfatto). $\mathrm{O}$ processualista dá a entender que este interesse se limitaria à afirmação do inadimplemento (sem nenhum outro acréscimo) ao afirmar que nas demandas condenatórias (assim como nas constitutivas) este interesse não seria "muito aparente". Cf. Manuale di diritto processuale civile, $5^{\mathrm{a}}$ ed., p. 146). 
objeto litigioso do processo nas demandas condenatórias não está no direito subjetivo apenas, mas na pretensão de direito material.

Com efeito, a causa de pedir ativa deve compreender, não apenas os fatos que fazem nascer o direito subjetivo, tais quais o contrato, o ato ilícito ou a previsão legal, mas, além disso, deve conter os fatos que tornam exigível a prestação desejada, além do inadimplemento correlato.

Assim, como nos casos de crises de situação jurídica, a crise de inadimplemento é, ao mesmo tempo, $(i)$ fato que, somado a outros (fatos jurígenos do crédito), faz nascer o direito pleiteado no pedido (parte da causa de pedir ativa); e (ii) fato que faz nascer o direito a uma análise a respeito do mérito (causa de pedir passiva). Daí porque se afirma que não existiriam distinções ontológicas entre o mérito e o interesse processual, nas demandas condenatórias. ${ }^{231}$

\subsection{CAUSA DE PEDIR PASSIVA E INDIVIDUALIZAÇÃO DA DEMANDA}

Definidos os conceitos de causa de pedir ativa e causa de pedir passiva, questionamos: a causa de pedir passiva é relevante para individualização da demanda? Duas demandas com as mesmas partes, o mesmo pedido e a mesma causa de pedir ativa podem ser distintas por possuírem causas de pedir passivas distintas?

Nossa resposta é negativa.

Como vimos, embora os mesmos fatos - em alguns casos - possam servir de critério simultaneamente para ambas, a causa de pedir ativa é "fato jurídico" regulado pelo direito material e, deste modo, deve se relacionar com o conteúdo do pedido, e a causa de pedir passiva, por sua vez, é "fato jurídico" regulado pelo direito processual, servindo à admissibilidade do julgamento de mérito. No entanto, apenas os fatos capazes de produzir os efeitos desejados com o pedido, i.e. causa de pedir ativa, devem ser considerados para a individualização do objeto litigioso do processo.

${ }^{231}$ A solução encontrada por Bedaque para este problema reside em uma análise meramente pragmática. Não existindo distinções ontológicas entre os fatos que configuram causa de pedir ativa e causa de pedir passiva nas demandas condenatórias, o processualista defende que, se a partir da simples narrativa da inicial seja possível identificar a inexistência de qualquer crise de adimplemento, o processo deve ser extinto sem julgamento de mérito. No entanto, caso seja necessário o contraditório e a instrução probatória para se identificar a ausência de inadimplemento ou a ausência de exigibilidade, o processo deverá ser decidido pelo mérito (cf. Efetividade do processo e técnica processual, p. 325). 
A razão de ser do estudo do objeto litigioso do processo reside na aplicabilidade de normas como a estabilização, a correlação, a litispendência e a coisa julgada (pressuposto processual negativo). Em todos estes casos, estamos preocupados com o contraditório, com a inércia, com a economia processual e com a segurança jurídica. Delimitamos o objeto da análise jurisdicional, para impedir que este seja alterado (prejudicando o contraditório e a inércia) e para impedir que este seja repetido enquanto ou após julgado (prejudicando a economia processual e a segurança jurídica).

Quando evidenciamos alterações na causa de pedir ativa, alteramos os limites da jurisdição, modificando as características da relação de direito material a ser concretamente determinada pela sentença (consequente da norma jurídica concreta). Assim, temos um pedido mediato diferente (já que ele se qualifica pela causa de pedir) e implicações mais relevantes quanto ao contraditório. No entanto, quando alteramos apenas os fatos que caracterizariam o interesse processual (sem alterar a causa de pedir ativa), não alteramos o bem da vida demandado (em todas as suas especificações) e tampouco o contraditório que se estabelece quanto ao mérito.

É certo que pode haver alteração no contraditório (objeto cognitivo do processo), afinal circunstâncias fáticas novas e relevantes para o processo seriam trazidas. Esta alteração justificaria a exigência de que o juiz dê cumprimento ao princípio da cooperação, e chame as partes para participar do debate. No entanto, não seria de gravidade suficiente para impedir um retorno do processo ao "estado anterior".

Forte indício a este respeito pode ser encontrado no direito positivo, ao passo que o Código de Processo Civil admite que o juiz reconheça de ofício os fatos que tratam da admissibilidade do julgamento de mérito, em especial, daqueles que configurariam o interesse processual (CPC, art. 267, $\left.\$ 3^{\circ}\right)$. Também merece ser mencionada a chamada "teoria da asserção", a indicar que, ainda que nos casos em que se mostrar ausente o interesse processual, tendo já o juiz condições adequadas de analisar o mérito, deve fazêlo.

O processo, de um modo geral, é instrumento da relação de direito material. Por consequência, fatos que têm relevância exclusiva para a técnica processual (e.g. o interesse processual), não deverão ser determinantes para individualizar o conteúdo da demanda. Este é delimitado objetivamente por aspectos da relação de direito material.

Esta questão é simples quando tratamos de demandas declaratórias e de demandas constitutivas. Pensemos em ação declaratória de inexistência de relação contratual, ajuizada por consumidor em face de empresa de telefonia que insiste por cobrar quantias 
decorrentes de linha telefônica jamais contratada. Tendo em vista o recebimento de carta de cobrança dos valores, o consumidor ajuíza uma primeira demanda, visando a declarar inexistente esta relação jurídica. No entanto, meses depois, a empresa resolve "negativar" o consumidor em sistema de proteção ao crédito. Em função desse "fato novo", o consumidor resolve propor uma segunda demanda, com a mesma causa de pedir ativa (nunca foi assinado contrato nem utilizada a linha) e o mesmo pedido (declaração de inexistência daquela relação jurídica).

Nos casos citados, teríamos todos os elementos da demanda iguais, exceto a causa de pedir passiva. No primeiro, a crise de certeza objetiva se estabeleceu a partir do encaminhamento de carta de cobrança. No segundo, a demanda tem fundamento em outra crise, diferente da primeira, pela qual a empresa se negou a reconhecer novamente a inexistência da relação jurídica, "negativando o nome" do consumidor. Seriam estas demandas distintas?

Os fatos que dão ensejo ao direito do demandante (não existir obrigação sem contrato, sem lei ou sem ato ilícito) serão os mesmos e o pedido será exatamente o mesmo (declaratório negativo, de modo a não lhe ser exigido o cumprimento de obrigação que não existe), variando apenas um elemento que diz respeito ao processo: interesse processual.

Nas duas demandas narradas teríamos exatamente o mesmo contraditório a respeito do mérito. Além disso, uma vez pendente/julgada a primeira demanda, não faria nenhum sentido sob o ponto de vista da economia processual e da segurança jurídica admitir a pendência/julgamento da segunda. Declarada a existência/inexistência da relação jurídica, terá sido entregue a tutela jurisdicional a respeito daquela relação conflituosa, de modo que a simples alteração da causa de pedir passiva não implicaria debate diferente acerca do mérito.

Vejamos hipótese de demanda constitutiva: consumidor relativamente incapaz, sem assistência, celebra contrato de compra e venda com concessionária de automóveis. Uma vez identificado o vício (CC, art. 171, I), a concessionária se recusa a realizar o desfazimento amigável do negócio jurídico. Configurada a crise de situação jurídica, o consumidor ajuíza ação constitutiva negativa. Ocorre que, meses depois, o consumidor identifica que a concessionária teria realizado o protesto deste mesmo contrato de compra e venda, sob o fundamento do inadimplemento da obrigação de pagar assumida com o contrato anulável. Desse modo, com a mesma causa de pedir ativa (contrato celebrado por relativamente incapaz) e com o mesmo pedido (anulação do contrato), o consumidor propõe nova demanda, agora, no entanto, pautado em uma nova crise de cooperação, não 
apenas há recusa em reconhecer a anulabilidade, como o demandado se recusa ao cooperar realizando atos incompatíveis com esta anulabilidade, tais quais os atos de cobrança.

Nos dois exemplos citados, observamos que a alteração da causa de pedir passiva não deverá alterar o conteúdo do resultado do processo, a sentença deverá assumir como premissa maior os mesmos fatos e deverá determinar a mesma consequência jurídica, independentemente da alteração da causa de pedir passiva. Por este motivo, não deverá alterar o objeto litigioso do processo.

Dito isso: questiona-se, o mesmo raciocínio se aplicaria às demandas condenatórias?

Caso considerássemos (como o faz parte da doutrina) que a exigibilidade da obrigação seria fato apto a configurar apenas o interesse processual (e não o mérito), haveríamos de entender que a causa de pedir passiva seria relevante para a delimitação do objeto litigioso do processo. Isto porque, apenas pelo aspecto da exigibilidade (e segundo esta posição, apenas pelo aspecto do interesse processual) uma demanda de cobrança pautada no vencimento antecipado da dívida pela perda das garantias $(\mathrm{CC}$, art. 333, I) não se confundiria com uma demanda de cobrança pautada no vencimento da obrigação pelo decurso do prazo contratual (CC, art. 333, caput). Tratariam de dois objetos litigiosos distintos.

Ocorre, no entanto, que expusemos acima o entendimento pelo qual a exigibilidade e o inadimplemento, embora possam ser relevantes para identificar a causa de pedir passiva (crise de adimplemento), não deixam jamais de serem fatos constitutivos do direito do demandante (fazem nascer a pretensão de direito material). Assim, alterando-os, embora possamos configurar alteração também na causa de pedir passiva, configuramos, antes, mudança na causa de pedir ativa.

Explica-se. Uma demanda de cobrança pautada em cobrança antecipada de dívida (CC, art. 333, I) é diferente de uma demanda pautada em cobrança pautada no decurso do prazo contratual (CC, art. 333, caput) porque, embora possa existir igualdade de pedido e partes, a causa de pedir ativa é diferente. Não apenas a crise de cooperação é diferente (inadimplemento), mas também são distintos os fatos que caracterizam o nascimento da pretensão de cobrança (direito de crédito + exigibilidade + inadimplemento), nos termos da norma substancial aplicável (CC, art. 331 e ss; STJ, Súmula 43 e 54, e outros).

Assim, podemos afirmar que, mesmo nas demandas condenatórias, a causa de pedir passiva deverá ser irrelevante para delimitar o objeto litigioso do processo: basta analisar se houve ou não mudança na causa de pedir ativa. Isto se dá, pois a mera alteração 
da causa de pedir passiva, inapta a implicar alteração também da causa de pedir ativa, não importará em modificação do objeto litigioso do processo.

\subsection{CONCEITO DE PARTE E SUA RELEVÂNCIA PARA A INDIVIDUALIZAÇÃO DA DEMANDA}

Por fim, chegamos ao conceito de parte. Referimo-nos no item 2.11 que o conceito de parte é um conceito processual, parte é (i) sujeito parcial da relação jurídica processual, (ii) com interesse privado na causa, (iii) que formula demanda ou em face de quem a demanda foi formulada e que, de algum modo, (iv) participa do contraditório, ( $v$ ) podendo ser afetada pelos efeitos jurídicos da sentença (efeitos principais) e da coisa julgada material, quando pertinente.

Para este conceito, nenhum aspecto da relação de direito material é considerado, de modo que, ainda que determinado sujeito tenha sido indevidamente levado ao contraditório processual (e.g. ilegitimidade ad causam), este indivíduo não deixa de ser parte no processo e de se submeter a todas as normas aplicáveis. ${ }^{232}$

Não obstante isso, a noção de parte é fundamental para a individualização da demanda, especialmente nos casos de legitimação ordinária. ${ }^{233}$ Dois indivíduos podem, com base nos mesmos fatos (causa de pedir), pleitear a produção dos mesmos efeitos jurídicos (pedido). Todavia, a despeito desta identidade parcial, e de ambas as demandas tratarem da mesma situação de direito material, as duas deverão ser fundamentalmente distintas.

E isto ocorre, pois o direito de demandar (uma das decorrências do direito de ação) existe para todos, indistintamente, e não contém limitações, condicionamentos, é um direito abstrato. Assim, mesmo a parte ilegítima pode formular tal pedido, sem que esta demanda implique identidade para com outra posterior ou anteriormente proposta, pela parte legítima. Do mesmo modo, a parte ilegítima pode ser indevidamente demandada,

\footnotetext{
${ }^{232}$ Apenas a parte legítima ou a parte substancial depende destes elementos para se caracterizar, mas não tratamos aqui deste conceito.

${ }^{233}$ A relevância das partes é distinta na identificação do objeto do processo nos casos de legitimação extraordinária ou mesmo de "legitimação autônoma para condução do processo", isto ocorre, pois, em princípio, seria possível conceber duas demandas idênticas com autores distintos. A questão, no entanto, não é pacífica e, por não representar o objeto da presente tese (que trata apenas do processo de conhecimento individual), resta aqui simplesmente ressalvada. Cf. Marcelo Abelha Rodrigues, Ação civil pública e meio ambiente, pp. 56-66.
} 
sendo submetida ao contraditório com fundamento em relação de direito material que lhe é absolutamente impertinente. ${ }^{234}$

As partes, portanto, são o único elemento de natureza eminentemente processual utilizados para a delimitação do objeto litigioso do processo, sem nenhuma referência à relação de direito material. Bastar estar no processo (ser sujeito da relação jurídica processual) para o ser.

Vimos que, quanto ao pedido e à causa de pedir, apenas os aspectos da relação de direito material concreta são relevantes para a delimitação do objeto litigioso, i.e. apenas o pedido mediato (e não o imediato) e apenas a causa de pedir fática (e não a causa de pedir jurídica) são úteis para a tanto. Em relação às partes, esta circunstância é distinta em função do princípio do contraditório e da ampla defesa.

Não é possível conferir os efeitos impeditivos de institutos como a duplicidade de litispendência e da coisa julgada a indivíduos que - mesmo que tenham figurada como sujeitos da relação de direito material (partes substanciais) - não tenham participado do diálogo processual. Por este motivo, e por uma questão de direito positivo (constitucional), não poderia o ordenamento jurídico conceber os critérios para a delimitação do objeto litigioso do processo sem levar em consideração este aspecto meramente processual.

234 A este respeito, cabe mencionar a pertinente distinção elaborada por Dinamarco a respeito dos conceitos de "parte na demanda" e "parte no processo". Para o autor, "são partes na demanda, rigorosa e exclusivamente, o autor que a propõe e o sujeito ali indicado como réu para que seja citado e venha assim a figurar na relação processual. Com relação às partes na demanda tem plena pertinência a clássica definição de partes como sendo aquele que a propõe, aquele em cujo nome ela se propõe e aquele em face de quem ela é proposta. Essa clássica definição (Chiovenda) foi formulada com vista a descrever as partes do processo, mas quanto a isso é falha porque há pessoas que não propuseram demanda alguma nem em face delas a demanda foi proposta e mesmo assim figuram na relação processual como sujeitos interessados, sendo portanto partes. Tais são (a) o assistente, que ingressa no processo para dar apoio a uma das partes principais, sem ser titular dos direitos e obrigações a serem objeto do pronunciamento final do juiz (infra, $\mathrm{n}$. 597) e (b) o Ministério Público, quando intervém em apoio a uma das partes principais ou na qualidade de custos legis (infra, n. 617), sem propor demanda alguma. A tendência natural é que venham a ser partes no processo precisamente aquelas pessoas que figuram como tais na demanda. Ao juiz é em princípio vedado determinar a inclusão de outro sujeito além daqueles que o demandante haja indicado, sendo também este impedido de fazer alterações subjetivas na demanda que propôs (estabilização subjetiva da demanda: art. 264). Mas há uma hipótese, rigorosamente uma só, em que o juiz tem o poder de fazer integrar no processo mais uma parte que a demanda não incluíra: se ali não figurar um sujeito cuja presença como réu seja indispensável (litisconsorte necessário), de-ofício ou a requerimento de parte ele determinará sua integração como parte processual, mediante a citação (art. 47, par.) (...) A pessoa indicada como réu na demanda não será parte no processo enquanto não vier a ser regularmente citada e se não o for até que aquele seja extinto. Sem citação, esse sujeito não se torna parte da relação processual e consequentemente não é lícito impor-lhe os efeitos da sentença”. (Dinamarco, Instituiç̧̃es de direito processual civil, vol. II, p. 272). 


\section{INTERPRETAÇÃO DA DEMANDA}

\subsection{DEMANDA, LINGUAGEM E INTERPRETAÇÃO}

Vimos no Capítulo 1 que à luz da filosofia da linguagem, a demanda é um "fazer por meio de palavras", um ato linguístico de natureza diretiva, que visa a produzir um efeito de convencimento em relação a seu interlocutor (juiz). ${ }^{235}$

Exatamente por se tratar de um ato linguístico, para ser compreendida e produzir efeitos, a demanda depende de um determinado contexto: sem convenções sobre o significado das palavras e orações nela utilizadas, e de suas possíveis consequências jurídicas, não é possível se exercitar eficazmente o ato de demandar. ${ }^{236}$ Mas, qual seria este contexto?

Por óbvio, são essenciais convenções linguísticas aplicáveis a todo e qualquer ato de fala (idioma). No entanto, além disso, o ato de demandar (por ser um ato jurídico) é regulado por normas de natureza jurídica. Existe um dado contexto normativo que o regula e vincula a possibilidade deste ato atingir seus objetivos.

Vimos, por este motivo, que há normas jurídicas que regulam o que deve estar presente na demanda (requisitos de regularidade - forma em sentido estrito) e o que, dentro da demanda, é capaz de individualizá-la (partes, pedido mediato e causa de pedir fática ativa).

Dito isso, esbarramos numa dificuldade já mencionada: a despeito de podermos identificar com relativa precisão estes elementos, o que é fundamental e o que não é numa demanda, não conseguimos chegar a critérios específicos aptos a delimitarem o conteúdo linguístico mínimo que deve estar presente em uma demanda e que, uma vez presente, deverá diferenciá-la das demais.

Sabemos que apenas o bem da vida almejado, o pedido mediato e não o imediato, é relevante para a delimitação do objeto litigioso do processo, sabemos também que este

\footnotetext{
${ }^{235}$ Cf. John R. Searle, Expressão e significado, 2002, p. 19.

${ }^{236}$ John Austin, ao conceber esta figura, afirma que um ato de fala não pode ser tratado como verdadeiro ou falso, na medida em que não trata de verdades ou mentiras. Ele exerce uma determinada função, e exatamente pelo fato deste ter aptidão para realiza-la, ou não, o ato pode ser considerado infeliz ou feliz. (cf. How to do things with words, 1962, p. 156). Nesse sentido, aplicando estas premissas, poderíamos afirmar que a felicidade do ato de demandar seria representada exatamente pela sua aptidão em instaurar um objeto litigioso de um processo e exigir uma manifestação judicial a seu respeito
} 
pedido mediato é representado pela vontade da parte no sentido de que os efeitos abstratos previstos pela norma jurídica sejam produzidos no mundo real, em concreto, alterando a realidade em favor do demandante. Mas qual descrição concreta desse benefício seria necessária para individualizar a demanda e delimitar o âmbito de atuação do juiz? Simplesmente pedir o pagamento de quantia decorrente de contrato de mútuo é suficiente para receber o valor acrescido de juros compensatórios ou significaria a vontade apenas de receber o principal? O mero pedido de ressarcimento de danos pessoais autorizaria o deferimento de indenização por danos morais e materiais? Podemos admitir a vontade tácita ou pedidos implícitos?

A resposta a todas estas questões deverá ser buscada a partir de critérios para interpretação da demanda. Interpretar uma demanda significa individualizá-la concretamente a partir de seu significado (semântica), extrair seus elementos essenciais, aptos a fazerem daquela demanda específica algo infungível, que não se confunde com nenhuma outra.

Quando falamos na interpretação da demanda, não estamos a sugerir que esta venha a ser interpretada ou mesmo apontar a utilidade de uma interpretação. Pelo contrário, partimos do pressuposto de que é impossível compreender uma demanda sem interpretá-la.

O conteúdo deste ato somente pode ser extraído a partir de um exercício intelectivo. Ovídio Baptista da Silva, ao transcorrer a respeito do "abandono da ilusão de que o raciocínio jurídico alcance a univocidade do pensamento matemático" ressalta a inexorabilidade da interpretação dos atos jurídicos:

\footnotetext{
"Encontramo-nos, realmente, no ponto de rotura entre o ideal do Iluminismo, em sua pretensão de obter a máxima segurança através do Direito, e as novas realidades sociais e políticas que nos impõem, com a força das potências históricas que as produziram, a abandonar essa perigosa ilusão. Teremos de regressar ao ponto em que o Direito, longe de ter a sonhada virtude de expressar-se através de uma linguagem unívoca, como pretenderam as filosofias liberais do século XVII, era aceito como essencialmente problemático, incapaz de admitir o raciocínio dedutivo, próprio da matemática".
}

Carlos Maximiliano, embora trate da lei, cuida do mesmo problema: "Que lei é clara? É aquela cujo sentido é expresso pela letra do texto. Para saber se isso acontece, é 
força procurar conhecer o sentido, isto é, interpretar. A verificação da clareza, portanto, ao invés de dispensar a exegese, implica-a, pressupõe o uso preliminar da mesma". ${ }^{237}$

Somente mediante juízo interpretativo é possível diferenciar demandas distintas e identificar demandas idênticas ou mesmo determinar até aonde pode ir o juiz ao decidir a causa e conceder a tutela jurisdicional, determinando i.e. ineficácia do ato extemporâneo, extinção sem julgamento de mérito, nulidade da sentença extra ou ultra petita, reunião de demandas conexas, prevenção, etc.

Todas estas regras processuais justificam-se por valores exteriores, relacionados à segurança jurídica, à previsibilidade, ao contraditório, à economia processual e à efetividade do processo. Com efeito, partindo da premissa da instrumentalidade do processo, passaremos a estudar como o direito regula a interpretação da demanda (metanormas processuais), à luz dos objetivos (escopos) que estas referidas normas jurídicas visam a assegurar.

\subsection{VONTADE NOS ATOS PROCESSUAIS E NA DEMANDA}

O primeiro passo para a interpretação do conteúdo da demanda está na identificação da relevância da vontade nos atos processuais, de um modo geral, e na demanda, especificamente. $\mathrm{E}$ isto porque a vontade no processo tem uma relevância restrita, menos abrangente se comparada a outros atos jurídicos, especialmente a aqueles regulados pelo direito privado.

Os efeitos dos atos processuais, ao contrário do que ocorre com os atos civis, são determinados diretamente pela lei, e não pela vontade. Os negócios jurídicos têm seus efeitos estipulados pelas próprias partes, que convencionam e estipulam as regras a regularem suas relações (direitos e deveres), com base no princípio da livre estipulação da vontade e da liberdade de disposição contratual (autorização legal, CC, art. 421). Os atos do processo, diferentemente, têm eficácia vinculada por normas pré-estabelecidas, que

\footnotetext{
${ }^{237}$ Cf. Processo e Ideologia..., 2 $2^{\mathrm{a}}$ ed., p. 270; e Carlos Maximiliano, Hermenêutica..., 1965, p. 50. A imprescindibilidade de um juízo de interpretação a respeito do conteúdo dos atos processuais foi retratada por João Francisco Naves da Fonseca, ao tratar da necessidade de interpretação do conteúdo da sentença, cf. "A interpretação da sentença civil”, Revista Dialética 62, p. 42 e ss.
} 
especificam requisitos e estipulam, desde logo, todos os efeitos a serem produzidos no mundo jurídico. ${ }^{238}$

Em muitos casos, a vontade do agente limita-se à realização, ou não, do ato, de modo que, para avaliarmos a eficácia de um ato processual, basta analisarmos a compatibilidade entre a forma de sua realização e o modelo formal previsto na lei. ${ }^{239}$

Avaliamos, em primeiro lugar, a lei que trata de requisitos de validade e eficácia dos atos processuais. Em segundo lugar, observamos a forma de exteriorização do ato em concreto, é dizer, o invólucro físico de que se reveste determinada manifestação de vontade. A subsunção do ato processual (evento físico) aos requisitos previstos pela norma permitirá seja aferida sua regularidade e, posteriormente, sua propensão a produzir efeitos. $^{240}$

Tais afirmações refletem distinções na intensidade da relevância da vontade, em relação a atos civis (negócios jurídicos) e a atos processuais. Todavia, não significam - e jamais poderiam significar - a irrelevância da vontade das partes no processo.

Em primeiro lugar, conforme demonstraremos, a vontade manifestada no ato processual é importante para identificar "a natureza" do ato (juízo de identificação), na medida em que não podemos nos pautar apenas na forma ou no nomen iuris (conforme veremos no item 5.4). Em segundo lugar, atos processuais de maior complexidade, especialmente os atos postulatórios argumentativos, têm seus efeitos vinculados à interpretação da vontade do agente, especificamente manifestada.

Sabemos que a extensão de um pedido recursal depende da vontade do recorrente e acaba por ser fundamental na determinação do efeito devolutivo do recurso de apelação, tantum devolutum quantum apelatum (CPC, art. 515). Interpretar o pedido recursal e afirmar quais capítulos da sentença foram impugnados, e quais não, é importante para

${ }^{238}$ A doutrina assevera a importância meramente secundária da vontade, no que tange à eficácia dos atos processuais. Cf. Liebman, Manuale..., Principi, 5 ed. p. 216; Crisanto Mandrioli, Diritto Processuale Civile..., 18 a ed, vol I, p. 418; Bedaque, Efetividade..., 2006, p. 413; e Marcelo Bonício, Capítulos de sentença..., p. 20.

${ }^{239}$ É importante considerar aqui a distinção feita pelos civilistas quanto ao "ato jurídico em sentido estrito" e ao "negócio jurídico". Para Farias e Rosenvald, "o ato jurídico em sentido estrito é o que gera consequências jurídicas previstas em lei (tipificadas previamente), desejadas, é bem verdade, pelos interessados, mas sem qualquer regulamentação da autonomia privada". Enquanto que o negócio jurídico seria composto de uma "composição de interesses, um regramento de condutas estabelecido bilateralmente, entre as partes envolvidas no acontecimento". (Cf. Farias e Rosenvald, Direito civil. Teoria geral. $7^{\mathrm{a}}$ ed., pp. 389 e 392 ).

${ }^{240}$ Calmon de Passos, evidenciando, inclusive, os eventos anteriores ao ato processual, que influenciam em sua validade, diferencia entre pressupostos, condições e requisitos dos atos jurídicos (Esboço de uma teoria... pp. 35-36). 
saber qual será a matéria objeto de julgamento do Tribunal e qual será a matéria que admitirá execução definitiva e imediata (submetida ao trânsito em julgado).

Do mesmo modo, interpretar o pedido e a causa de pedir de uma demanda é relevante para determinar o objeto litigioso do processo e, por consequência, até onde pode/deve ir o juiz ao decidir ou conceder a tutela jurisdicional (CPC, art. 128 e 460). Isso somente é possível mediante juízo interpretativo.

\subsection{INTERPRETANDO A DEMANDA}

Estabelecida a relevância da vontade nos atos processuais, e na demanda especificamente, a questão que agora se coloca é: como esta vontade deve ser interpretada?

A demanda é um ato linguístico e pressupõe o registro, físico e estanque, de um pensamento, mediante a descrição de um episódio da vida supostamente relevante para o direito e da pretensão de que determinados efeitos sejam produzidos. Este registro, ainda que muito bem documentado, admite diferentes leituras, na medida em que é incapaz de retratar todos os detalhes da realidade.

Muitas vezes representa um corte arbitrário do demandante, numa determinada cadeia de fatos ou numa determinada relação social mais complexa. É a sua visão, devidamente reconstruída num texto desenvolvido de modo parcial. ${ }^{241}$ A este respeito, Daniela Monteiro Gabbay assenta que:

\footnotetext{
"o pedido é apenas uma moldura mais restrita do conflito que, pelas regras do processo civil individual, é construída unilateralmente pelo autor, enquanto o conflito subjacente (realidade esta intranscendível pelo pedido), mais próximo da realidade intersubjetiva das partes envolvidas, e
}

\footnotetext{
${ }^{241}$ A linguagem poética de Rauol de la Grasserie ressalta o fenômeno: "soa como um paradoxo a questão de saber se, em geral, a palavra está em condições de transmitir o pensamento. É, todavia, séria a dúvida, e até comporta uma solução negativa. O pensamento é um fato interno da vida intelectual subjetiva, uma atividade, um movimento, uma ondulação do espírito; ora um movimento não se deixa traduzir objetivamente. É mediante a condição de perder a sua própria essência, de se fixar, que o pensamento pode sair do seio da intimidade subjetiva para entrar no mundo exterior. O pensamento expresso é, por assim dizer, um pensamento gelado. Só em sentido impróprio se pode falar de comunicação ou transmissão do pensamento. O pensamento, propriamente considerado, não se transmite. A palavra apenas provoca um pensamento semelhante, e torna-o possível; não faz mais do que produzir na alma do ouvinte um movimento intelectual semelhante àquele que se produz na do indivíduo que fala". (De la Justice en France et à l'Étranger au XXe Siécle, vol. 1, pp. 123-124, apud Carlos Maximiliano, Hermenêutica..., 1965, p. 129). Cf. ainda Flávio Yarshell, Tutela Jurisdicional, $2^{\text {a }}$ ed. p. 51.
} 
mediado pela linguagem, teria seus contornos mais abrangentes, dependendo da perspectiva do observador". 242

Na petição - suporte físico da demanda - há um emaranhado de signos, a formarem orações, a denotarem diferentes proposições e a exercerem diferentes funções linguísticas. Parte da demanda descreve fatos (causa de pedir fática) e identifica sujeitos (partes), parte descreve a linguagem prescritiva do direito positivo em metalinguagem jurídica $^{243}$ (causa de pedir jurídica) e outra exerce função distinta da meramente descritiva, visando a obter o convencimento (pedido). ${ }^{244}$

Todos esses signos - dotados de sentidos convencionados em determinado idioma - pressupõem uma adicional contextualização, relativa ao ambiente em que mencionados. Não basta buscar referências individuais de sentido para cada um dos signos usados (como faríamos se recorrêssemos ao dicionário para obter o sentido de cada palavra), é necessário sempre tentar compreendê-los a partir do contexto em que foram mencionados.

Por este motivo, a vontade da parte, manifestada no seu pedido, deve ser interpretada racionalmente à luz dos fatos (motivos) que justificaram este pedido, bem como à luz da linguagem do direito positivo a regular aquela situação fática relevante para a demanda.

O pedido é representado pela vontade da parte no sentido de que determinados efeitos jurídicos sejam produzidos no caso concreto. Tais efeitos jurídicos são previstos na linguagem prescritiva do direito, nos mais variados textos legais, por meio de expressões tais quais anulação, indenização, declaração de nulidade, multa, etc. Estes mesmos efeitos são qualificados ou quantificados por meio do uso de outras expressões, tais quais $(i)$ anulação da cláusula ou anulação do contrato, (ii) indenização por danos estéticos ou (iii) indenização por danos morais ou mesmo (iv) indenização por danos pessoais, (v) declaração de nulidade do contrato ou (vi) declaração de nulidade de cláusula contratual, (vii) multa contratual ou multa administrativa prevista pela Lei X, e assim por diante.

Não bastasse isso, cada anulação, indenização, declaração de nulidade, multa, ainda que qualificada por outras expressões na formação do pedido, somente fará sentido se contextualizada a partir dos fundamentos de fato do pedido (causa de pedir remota). E isto porque, conforme vimos no item 3.9, o pedido somente faz sentido, pode ser

\footnotetext{
${ }^{242}$ Cf. Daniela Monteiro Gabbay, Pedido e causa de pedir, p. 34.

${ }^{243}$ Cf. Lourival Vilanova, Estruturas lógicas e o sistema de direito positivo, $3^{\mathrm{a}}$ ed., p. 55 e ss.

${ }^{244}$ A função do pedido é diretiva, e não assertiva. Cf. John R. Searle, Expressão e significado, 2002, p. 19 e ss.
} 
compreendido, a partir dos fatos indicados pelo demandante como aptos a desencadearem seus efeitos (fatos jurígenos).

Ao indivíduo que pretende interpretar a demanda, extrair seu conteúdo, é inevitável que antes supere todas estas questões e logre êxito em considerar tanto as circunstâncias de fato quanto as circunstâncias de direito que fundamentam o pedido e que, conforme demonstraremos a seguir, devem ser sempre dirigidas à luz do princípio do contraditório.

\subsection{CONTRADITÓRIO COMO REFERÊNCIA À INTERPRETAÇÃO DA DEMANDA}

Para que possamos definir um critério para a interpretação da demanda, temos que formular duas perguntas fundamentais (i) por qual motivo deve a demanda ser interpretada? (ii) quem interpreta a demanda?

Quanto à primeira questão, vimos anteriormente que a demanda deve ser interpretada de modo que dela possa ser extraído o conteúdo que deverá ser objeto de apreciação jurisdicional (objeto cognitivo e litigioso do processo), delimitando a extensão do contraditório e da atividade do Estado-juiz.

Quanto à segunda questão, temos de reconhecer que todos os sujeitos do processo têm a incumbência de interpretar a demanda, para participarem ou mesmo para escolherem não participar do debate processual. No entanto, o direito positivo se preocupa mais especificamente com a interpretação que o juiz deverá fazer a respeito do conteúdo da demanda.

O juiz deve se valer de critérios que levem em consideração as efetivas possibilidades de participação dos sujeitos processuais ao interpretar o conteúdo da demanda. É, portanto, o princípio do contraditório, na sua vertente da cooperação, o parâmetro principal a regular o modo pelo qual o juiz deve interpretar a demanda. ${ }^{245}$

\footnotetext{
${ }^{245}$ Cf. Edoardo F. Ricci, "Princípio do contraditório e questões...", Processo e Constituição, p. 496 e ss. Para Miguel Teixeira de Sousa, "o liberalismo clássico, de inspiração burguesa e capitalista, construiu um processo dominado pelas partes e caracterizado pela passividade do juiz; - as várias ideologias não liberais, sejam elas de carácter autoritário ou de orientação democrática ou social, conduziram a um processo submetido ou pelo menos, comparticipado pela atividade do juiz". ("Aspectos do novo processo civil português", Repro 86, p. 174). Do mesmo modo, em referência ao processo civil estadunidense, Owen Fiss ressalta que "o modelo de solução de controvérsias prevê um papel passivo para o juiz. Ele deve permanecer como um árbitro ou observador entre as duas partes, confiando em todas as iniciativas destas para a apresentação dos fatos, do direito e para a articulação das possíveis medidas judiciais". O próprio autor, no
} 
Não há, aqui, signos isolados, com sentidos dicionarísticos, mas sentidos construídos a partir de um contexto específico, caracterizados pela narrativa de fatos, pelo contexto de sua manifestação e pela vontade manifestada, que - numa determinada demanda - depende da compreensão dos fatos que a motivaram, das relações sociais subjacentes e fundamentalmente das convenções sociais aplicáveis.

É preciso investigar, sempre à luz do homem médio, o que normalmente acontece, qual é a representatividade daquela expressão, daquele signo utilizado na demanda. O que aquelas palavras, naquele contexto específico, devem significar. ${ }^{246}$ Concordamos, assim, com a premissa de Passo Cabral, pela qual "num ambiente plurissubjetivo como o processo, as prognses de um sujeito devem tomar em consideração as expectativas e os comportamentos dos demais". ${ }^{247}$

Esta identificação é fundamental, pois a demanda será levada ao contraditório, e o sentido a se extrair da demanda pelo juiz (sua interpretação) deve ser aquele que razoavelmente pode ser exigido do demandado e dos demais sujeitos processuais. O juiz deve levar em consideração a compreensão do homem médio, naquele contexto, quanto ao conteúdo do ato de demandar, pois somente assim poderá posteriormente considerar (presumir) que estes tiveram efetivas condições de se manifestar a respeito do conteúdo que deverá servir de objeto para a decisão. A este respeito leciona Barbosa Moreira:

"O exercício amplo do direito de defesa implica necessariamente para o réu um mínimo de
previsibilidade. É preciso que ele saiba, ao ser convocado a juízo, ou possa verificar com os dados
de que dispõe, quais são as suas chances, tanto para o melhor, quanto para o pior. É preciso que ele
possa avaliar desde logo qual a pior coisa que lhe pode acontecer na hipótese de derrota. (...)
Dependendo das circunstâncias, o réu poderá optar com fundamento sólido, optar conscientemente
entre diversas atitudes, inclusive a de não defender-se, desde que esteja seguro do limite máximo
do prejuízo que poderá vir a sofrer, se derrotado. Esse elemento de previsibilidade é absolutamente
essencial para que o réu possa exercer amplamente o seu direito de defesa. Isto se liga com a
problemática relativa ao pedido. É por isso que o pedido tem de ser certo e determinado. Apesar de
o texto do Código usar a conjunção "ou" (pedido certo "ou" determinado), a doutrina e a

entanto, não deixa de registar críticas a essa visão. (Um novo processo civil, p. 58). Em relação ao processo civil francês, cf. Croze e Morel, Procèdure civile, 1988, p. 166 e ss.

${ }^{246}$ Ao asseverar a relevância da cooperação e boa-fé entre os litigantes, Passo Cabral sustenta que "esta alteridade no exercício do contraditório impõe deveres de conduta e chama os litigantes a uma introspecção para que o desempenho de seus comportamentos processuais releve o uso responsável e consciente de suas prerrogativas (autorresponsabilidade)". E conclui: "a prática dos atos processuais deve levar em consideração não só a avaliação racional da conduta à luz dos atos praticados por outrem, mas também a projeção comunicativa do próprio comportamento para os demais sujeitos". (Coisa julgada e preclusões dinâmicas, 2013, p. 410).

${ }^{247}$ Cf. Antonio do Passo Cabral, Coisa julgada e preclusões dinâmicas, 2013, p. 465. 
jurisprudência são unânimes em considerar que, na verdade, se trata de aspectos que se complementam, e, portanto, o "ou" deve ser lido como "e": não é uma alternativa, e sim uma adição. É pela razão exposta que se quer que o pedido seja certo e determinado, e é por isso que se quer também que a sentença se atenha a esse pedido certo e determinado". ${ }^{248}$

Entendemos aqui, portanto, que o contraditório exerce papel chave no juízo de interpretação do ato postulatório. Não é lícito ao juiz valer-se de um contexto linguístico específico - eventualmente acessível a ele e ao demandante - para admitir sentidos para a demanda que, razoavelmente, não poderiam ser exigidos do demandado ou de outros sujeitos do processo. Interpretações heterodoxas, pautadas em especificidades técnicas, regionais, científicas e que não considerem o contexto social da realização do ato, podem levar à ausência de contraditório ou a um contraditório defeituoso.

É evidente, desse modo, que esta concepção deve variar do ambiente do processo, não sendo viáveis os mesmos critérios de interpretação - ainda que falemos de demandas idênticas - quando tratamos e.g. de procedimento como o dos juizados especiais, que admitem o jus postulandi, e do procedimento comum, que exige a representação por advogado. Circunstâncias como esta devem ser levadas em consideração.

Mais do que isso, a "sabedoria do homem comum" é referência para a técnica processual em diferentes quadrantes. O Código de Processo Civil, nos termos do art. 335, exige que o juiz capte a normalidade e decida com base no que normalmente acontece naquele contexto social: "Em falta de normas jurídicas particulares, o juiz aplicará as regras de experiência comum subministradas pela observação do que ordinariamente acontece (...)".

Também a interpretação das provas pode ser motivada pela concepção do juiz a respeito do que "normalmente acontece", tal como determina o artigo 371, III, do Código de Processo Civil: "Reputa-se autor do documento particular: (...) aquele que, mandando compô-lo, não o firmou, porque, conforme a experiência comum, não se costuma assinar, como livros comerciais e assentos domésticos".

Outra circunstância relevante é a que veda ao juiz, mesmo que conhecedor de questões técnicas relevantes para a causa e apto a avaliar os fatos, não possa fazê-lo sem o auxílio de um perito do juízo e de um laudo pericial produzido em contraditório (CPC, arts. 145 e 421$)$.

${ }^{248}$ Barbosa Moreira, “Correlação entre o pedido e a sentença”, RePro 83, p. 209. 
Seguindo esta linha, João Naves da Fonseca ressalta a necessidade de os atos processuais serem interpretados a partir das concepções medianas a respeito do que normalmente acontece. Ressalta, assim, que a lógica dedutivo-formal não apresenta solução adequada para o problema. "É que a lógica formal, por ser meramente enunciativa do ser e do não ser, não tem uma previsão sobre os fins, sobre a congruência entre os meios e os fins, nem sobre a eficácia dos meios em relação a um certo fim. Por isso seu emprego pode resultar em soluções absurdas".

O autor se pauta no exemplo citado por Recaséns Siches, no qual havia norma em estação de trem polonesa que proibia a entrada de passageiros com cachorros e que, certo dia, por se entender excluído da proibição, determinado passageiro pretendeu ingressar com um urso. De fato, urso não é cachorro, mas a interpretação literal da proibição não haveria de ser a mais adequada, pois se menos (cachorro) não se pode, quiçá se poderia mais (urso). ${ }^{249}$

Assim, vemos que o juiz deve ser pautar nesses relativos parâmetros de normalidade ao conduzir o processo, valendo-se da mesma lógica quando da interpretação do conteúdo da demanda e dos demais atos processuais. Esta circunstância deve ser mais bem esclarecida adiante, quando tratarmos dos exemplos de interpretação do pedido desenvolvidos pela jurisprudência. Mas o fato é: a despeito das dificuldades encontradas em qualquer juízo de interpretação, temos de considerar que, quando interpretamos a demanda, o direito positivo (especialmente a garantia constitucional do contraditório) oferece referências objetivas para direcionar este exercício.

\subsection{INCERTEZA NA DEMANDA E INTERPRETAÇÃO RESTRITIVA}

Tendo em vista os problemas semânticos enfrentados por todo e qualquer ato linguístico, vimos que a interpretação de uma demanda é por si só uma atividade complexa. No entanto, este quadro se deteriora quando identificamos - além das circunstâncias normais demonstradas acima - vícios de comunicação no ato de demandar.

Linguagem demasiadamente imprecisa para retratar os fatos, o direito e o pedido dificulta a delimitação do objeto litigioso do processo, prejudica o contraditório e

\footnotetext{
${ }^{249}$ Cf. Naves da Fonseca, “A interpretação da sentença civil”, Revista Dialética 62, p. 42 e ss.
} 
compromete a atuação do juiz, que passa a carecer de referência precisa quanto ao objeto sobre o qual deverá recair sua atividade cognitiva (objeto cognitivo do processo) e decisória-executiva (objeto litigioso do processo). ${ }^{250}$

Há a tendência inicial de tentar diminuir essa incerteza, por meio de técnicas interpretativas. O próprio direito positivo prescreve que o conteúdo da demanda deve ser interpretado de forma restritiva: "os pedidos são interpretados restritivamente" (CPC, art. 293). E mais: exige que a linguagem referente à demanda seja precisa do ponto de vista semântico e indique de forma certa ou determinada o bem da vida almejado: "o pedido deve ser certo ou determinado" (CPC, art. 286). ${ }^{251}$

As consequências jurídicas dessas normas são duas.

A primeira é no sentido de que, não sendo minimamente precisa a linguagem da demanda, ao ponto de reduzir as ambiguidades e imprecisões, o processo não terá aptidão ao julgamento de mérito, merecendo ser extinto após fracassadas as tentativas de regularização (inadmissibilidade da demanda). Não pode o instrumento prosseguir a uma análise de mérito se o conteúdo deste - em si mesmo - é incerto e não pode ser devidamente identificado, prejudicando tanto a resposta à pretensão, a ser realizada pelo demandado, quanto a apreciação jurisdicional.

Os pressupostos da admissibilidade do julgamento de mérito são importante filtro - e como qualquer norma processual - atendem a escopos específicos, na hipótese, o disposto no art. 282, III, do CPC e a sanção de inadmissibilidade pelo seu desrespeito visam a resguardar que o processo respeite o contraditório, especialmente, que não prossiga nos casos em que a delimitação do objeto litigioso é imprecisa, confundindo os sujeitos processuais do processo e tornando nebulosos os limites da atuação jurisdicional. ${ }^{252}$

A segunda consequência, por sua vez, diz respeito ao fato de que, formulada a demanda e presente qualquer ambiguidade quanto ao seu conteúdo (ainda que pequena), as partes e o juiz deverão interpretá-la de forma restritiva: existindo mais de uma interpretação possível, deverão escolher aquela que represente uma abrangência menor.

\footnotetext{
${ }^{250}$ Conforme ensina Giorgio Del Vecchio, a incerteza do direito produz inconvenientes gravíssimos, pois "contradiz diretamente" a uma das razões essenciais do próprio direito, que representa ordem e garantia nas relações sociais. Referindo-se a Bacon, o professor ressalta que a certeza da lei é tão importante, pois se esta não for certa, certamente não será justa (La crisi della scienza del diritto, 1933, p. 6).

${ }^{251}$ Embora literalmente o texto da lei refira-se ao pedido, entendemos que se cuida aqui da interpretação da demanda e da identificação do conteúdo apto da delimitar o objeto litigioso do processo. Isto se dá, pois, como visto, o pedido faz sentido apenas se relacionado à causa de pedir e às partes.

252 Já tivemos a oportunidade de ressaltar a relevância dos pressupostos processuais para os escopos do processo, cf. Marcelo Pacheco Machado, Incerteza e Processo, 2013, p. 21.
} 
A técnica aqui é parecida com a técnica da "interpretação conforme" muito estudada pelo Direito Constitucional no Controle de Constitucionalidade. O legislador, admitindo que o texto normativo tem uma moldura de significados possíveis ${ }^{253}$ - seja um texto da lei ou um texto da demanda - admite a possibilidade de limitar estes significados, numa tentativa de salvaguardar a validade do ato. Ao invés de excluir o texto do mundo jurídico, "como se nunca tivesse existido", simplesmente torna essa moldura mais restrita, delimitando significados possíveis, e excluindo outros significados que julga inviáveis. ${ }^{254}$

Ao fazê-lo exerce uma espécie de "sanatória intelectual" - sem a necessidade de complementação ou retificação do ato - com o objetivo de reduzir as incertezas internas ao processo e, como reiteradamente exposto, maléficas ao exercício pleno do contraditório. Restringir, ao mínimo possível, o conteúdo da demanda, significa ter melhores condições de impedir que o demandando e os demais sujeitos do processo, mediante uma outra interpretação possível (razoável), possam deixar de participar adequadamente do diálogo processual. Esta parece ser a posição de Dinamarco:

“Toda dúvida fundada e razoável deve levá-lo a optar pelo mais estrito e nunca pelo mais amplo. Essa linha de orientação deve prevalecer tanto em relação ao pedido, quanto à causa de pedir. Se a redação da petição inicial deixa dúvidas sobre se o autor pretende a anulação do contrato somente por erro, ou por erro e coação, é dever do juiz optar pela primeira hipótese. Se não for possível retirar da petição inicial certeza quanto a pretender o autor a condenação do réu a cumprir uma cláusula do contrato, ou duas, ou três, que considere sempre a mais estrita das hipóteses".

Informações adequadas são pressuposto de qualquer reação efetiva, para que seja possível se insurgir, ou mesmo se manifestar adequadamente contra alguma coisa, é antes fundamental o conhecimento a respeito daquilo contra o que se reage ou se manifesta. ${ }^{255}$ Ademais, admitindo-se que o juiz não está autorizado a extrapolar ou minorar o objeto litigioso do processo, a incerteza relativamente a este acaba por tornar incertos os limites da própria atuação jurisdicional.

\footnotetext{
${ }^{253}$ Cf. Hans Kelsen, Teoria pura do direito, 2003, p. 390 e ss.

254 A técnica da interpretação conforme a Constituição parte do pressuposto de que uma lei pode ter vários sentidos, dentre estes, alguns sentidos inconstitucionais. Desse modo, admite-se em controle de constitucionalidade que o Tribunal interprete restritivamente o conteúdo da lei, dizendo que ela dever assumir apenas aquele sentido "em conformidade com a Constituição" e vedando expressamente sua interpretação inconstitucional. Cf. Ives Gandra da Silva Martins e Gilmar Ferreira Mendes, Controle concentrado de constitucionalidade, $2^{\mathrm{a}}$ ed., 2005, pp. 410 e 411.

${ }^{255} \mathrm{Cf}$. Dinamarco, Instituições de direito processo civil, vol. I, item 85.
} 


\subsection{INTERPRETAÇÃO RESTRITIVA É REGRA GERAL?}

É adequada a solução prevista pela lei, no sentido de reduzir ou eliminar as possibilidades de incerteza ao restringir o número de significados possíveis a serem extraídos daquele ato linguístico. No entanto, perguntamos: o Código nos obriga sempre a interpretar restritivamente o pedido e a causa de pedir?

Questionamos isso, pois esta diretriz parece entrar em colisão com a ideia de efetividade do processo; reduzir ou restringir os significados possíveis da demanda significa, em última análise, reduzir as possibilidades da Jurisdição e diminuir a parcela do litígio (crise social) a ser apreciada pelo Poder Judiciário.

Ao limitarmos a abrangência do pedido, dentro de diferentes casos concretos, por deficiências na confecção da demanda, ou por dificuldades concretas apresentadas pelas cambiantes relações sociais, podemos inviabilizar a solução mais adequada do conflito. Do mesmo modo, ao restringirmos os fatos alegados na inicial reduziríamos a abrangência da matéria levada a julgamento e que, por sua vez, deverá será pacificada pela atividade jurisdicional.

Diferentemente, ter maior amplitude para trabalhar, ou poder construir um número maior de significados, a partir do suporte físico da demanda, significa conceder mais poderes de atuação ao juiz, dando-lhe a oportunidade de viabilizar resultados mais amplos, que abrangem uma maior parcela da relação conflituosa e que potencializam o escopo social do processo (pacificação).

A interpretação da demanda, portanto, deve ser pautada em suas exigências fundamentais: segurança jurídica e efetividade do processo. Por este motivo, a interpretação restritiva deve ocorrer apenas nos casos de ambiguidades, nos quais há razoáveis dúvidas quanto ao sentido da manifestação de vontade. Sendo esta suficientemente clara e adequada a propiciar o contraditório, não há motivo para quaisquer restrições ou interpretações restritivas. ${ }^{256}$

\footnotetext{
${ }^{256}$ Recorremos novamente a Dinamarco: “A interpretação justa das demandas não deve ser restritiva nem ampliativa, mas declarativa, i.é, ela deve colher com precisão o significado das palavras usadas pelo demandante. As restrições conduziriam a sentenças citra petita, que por sua vez importam denegação de justiça. Onde o art. 293 fala em interpretação restritiva, leia-se interpretação estrita. O legislador majus dixit quam voluit. A interpretação restritiva das leis resulta geralmente do confronto do texto com outras disposições, garantias ou princípios contidos no ordenamento jurídico como um todo (interpretação sistemática). As demandas são interpretadas em si mesmas e eventuais abusos são repelidos por outro modo, não pela interpretação. A segunda ressalva à redação do art. 293 do Código de Processo Civil consiste na observação de que não só em relação ao pedido essas regras se aplicam, mas de igual modo à causa petendi.
} 
Nos itens seguintes, pretendemos determinar de que modo se dará o equilíbrio entre as citadas exigências antagônicas (segurança jurídica $v s$ efetividade do processo) no ato de interpretação da demanda, à luz das normas constitucionais e das técnicas previstas pela lei ordinária.

\subsection{CERTEZA DO PEDIDO OU DO OBJETO LITIGIOSO?}

A exigência legal de que o pedido seja certo e determinado mantém relação direta com a garantia do contraditório, conforme o artigo 286 do Código de Processo Civil. A precisa identificação da vontade da parte, como visto, tem relação com as efetivas chances de resposta do demandado e com as limitações da atividade jurisdicional.

A doutrina se refere à expressão an debeatur para designar a certeza do pedido (especialmente nas tutelas condenatórias), ressaltando a circunstância de que esta tem relação com “o que é devido". Pedido certo é aquele que (i) individualiza a categoria do bem da vida almejado, e.g. construção de muro, entrega de sacas de café arábica, demolição de obra, não divulgação de informação, indenização por danos morais ou materiais sofridos em função de dada conduta, pagamento de multa contratual, etc. e que (ii) contextualiza esta categoria ou efeito jurídico a uma situação concreta, o que somente pode ser feito recorrendo-se à causa de pedir, e.g. construção de muro no limite sul do imóvel X em função do contrato celebrado em 24 de agosto de 2012.

Nesse aspecto é relevante a crítica de Zanzucchi à teoria da individualização, ao afirmar que, mesmo nos direitos absolutos, é impossível identificar uma demanda sem uma relação direta a fatos concretos, em narrativa histórica (cf. item 2.9). Não basta identificar abstratamente a categoria do bem da vida almejado, simplesmente indicando "construir muro" ou "entregar sacas de café", é necessário individualizar este bem da vida a um caso concreto, inserir-lhe num específico contexto histórico de fatos. ${ }^{257}$

Quando falamos de tutelas condenatórias, identificamos o bem da vida a partir descrição da fonte da prestação exigida pelo processo, tal qual o específico contrato, ato ilícito ou relação jurídica que fez nascer a prestação exigida como bem da vida. Quando

Não se ampliam nem se restringem os fundamentos trazidos pelo autor, simplesmente proíbe-se que o juiz opte pela interpretação mais larga sempre que haja séria dúvida quanto à amplitude da fundamentação". (Dinamarco, Instituições de direito processual civil, vol. II, pp. 135-136).

${ }^{257}$ Cf. Zanzucchi, Nuove domande..., p. 336-337. 
falamos em tutelas constitutivas, temos de identificar concretamente a causa ou o motivo para a constituição, modificação ou extinção da relação jurídica, bem como a própria relação jurídica a ser constituída, modificada ou extinta, a partir de seus elementos essenciais. Por fim, quando falamos em tutelas declaratórias, precisamos identificar os precisos limites da relação jurídica que pretendemos declarar existente ou inexistente.

A exigência de "certeza do pedido", portanto, é uma exigência de certeza a respeito de toda a demanda, a respeito do conteúdo do objeto litigioso do processo, útil para individualiza-lo e diferenciá-lo dos demais, e não apenas do pedido.

\subsection{LIQUIDEZ DO PEDIDO: EXTENSÃO DA VONTADE}

A linguagem prescritiva do direito exige do pedido, além da certeza, determinação ou liquidez (CPC, art. 286). Diferentemente da certeza, a liquidez do pedido não está relacionada com a identificação de um determinado objeto litigioso e, por este motivo, pode ser mitigada ou relativizada em face de determinadas circunstâncias.

Explicamos.

Um mesmo pedido decorrente de um mesmo fato (descrito na causa de pedir) pode se manifestar em intensidades distintas, e a liquidez é a medida da intensidade deste efeito, sua quantificação. Conforme leciona Wambier: "mais do que se referir apenas à determinação da quantidade de coisas, diz respeito também à indicação de extensão, volume, medida, enfim, à grandeza ou tamanho daquilo que deve ser prestado". ${ }^{258}$

Nas tutelas condenatórias, pedido líquido é aquele que reúne elementos aptos à quantificação do que é devido, isto é, que delimita quantitativamente o objeto da relação de direito material, e.g. construir muro de $\mathrm{X}$ metros de altura e $\mathrm{X}$ metros de cumprimento, entregar $\mathrm{X}$ sacas de café, pagar indenização de $\mathrm{X}$ reais, pagar multa de $\mathrm{X}$ reais, etc. Assim leciona Dinamarco:

\footnotetext{
"Quanto às coisas certas, a certeza é suficiente e sequer se cogita de quantificação, simplesmente porque elas são individuais em si mesmas (tal imóvel, tal contrato); as coisas incertas serão indicadas, ao menos, pelo gênero e quantidade (CC, art. 874). Quem pretende uma quantidade de bens mensuráveis em número de unidades tem o ônus de indicar o montante quantitativo
}

${ }^{258}$ Cf. Wambier, Sentença civil: liquidação e cumprimento de sentença, $3^{\mathrm{a}}$ ed., p. 111. 
pretendido, para o preciso dimensionamento da tutela jurisdicional possível (arts. 128 e 460). É o que se dá quando o pedido é de condenação em dinheiro ou em outros bens fungíveis (CC, art. $50) " .259$

Nas tutelas declaratórias e constitutivas, no entanto, a certeza e a determinação do pedido parecem se confundir. Ambas tratam de identificar e especificar os contornos de determinada relação jurídica (e.g. contrato, casamento, etc.) ou de determinado aspecto de uma relação jurídica (e.g. cláusula contratual, regime de casamento, etc.), ainda que se almeje declarar inexistente uma proto-relação-jurídica.

Não faz sentido pensar em diferentes intensidades para o pedido de desconstituição de um contrato, de anulação de um casamento ou de declaração de inexistência jurídica de um título de crédito, ou se pode criar, modificar, extinguir ou não se pode, ou se pode declarar existente ou inexistente, ou não se pode.

Ora, mesmo que desejemos anular ou declarar inexistentes 2, 3, 4, 5 ou vários contratos, a individualização de cada uma dessas pretensões em cúmulo simples seria um problema de identificação do objeto (cumulo objetivo de pedidos), e não de quantificação. Um contrato é diferente do outro, e a expressão anular 5 ou 10 contratos, sem uma referência individual a cada um, não faria sentido.

Não importa o que ocorra, o pedido deve ser certo, pois a ausência de certeza do pedido representaria um bem da vida não identificado. A iliquidez do pedido, no entanto, pode ser tolerada excepcionalmente, nos casos em que $(i)$ o bem da vida almejado relaciona-se a uma universalidade de bens, como a herança (CC, art. 57); e que (ii) no momento da propositura da demanda, o demandante demonstrar que não tem condições razoáveis de delimitar o quantum dabeatur, especialmente porque este depende da obtenção de informações que naquele momento ainda não se encontrariam disponíveis (CPC, art. 286, I a III).

A ideia original é no sentido de que, em dadas situações, apenas depois de produzida a prova e iniciado o debate processual, o demandante passaria a ter condições de quantificar - com precisão matemática - a extensão do seu pedido, ao passo que no momento da propositura da demanda, pela ausência de elementos fundamentais, este cálculo seria inviável.

O melhor exemplo residiria no pedido de condenação em despesas médicas decorrentes de vítima em acidente de trânsito que, na data da propositura da demanda,

${ }^{259}$ Cf. Dinamarco, Instituições de direito processual civil, vol. II, item 444. 
ainda se encontraria no hospital. Apenas após o fim do tratamento será possível a quantificação, mas o direito à reparação de danos já existe e a propositura da demanda é viável, mediante pedido genérico.

Ocorre que, não obstante os critérios legais, a jurisprudência tem se mostrado ainda mais flexível que a lei, admitindo com pouquíssimas restrições a formulação de pedido ilíquido. ${ }^{260}$ Especialmente na hipótese do artigo 286, II, do Código de Processo Civil, tem declarado, de forma não muito clara, que "não se rejeita o requerimento genérico se, mesmo deficientemente formulado, permitir a correta compreensão de seu alcance e a ampla defesa da parte adversa". ${ }^{261}$

A aceitação do pedido ilíquido é maléfica para o sistema, e não pode ser generalizada. Uma demanda devidamente quantificada permite a concentração do contraditório num único momento, e aumenta as possibilidades de prolação de uma sentença líquida, capaz de ser imediatamente executada. Diferentemente, um pedido ilíquido pressupõe trabalho dobrado, na fase cognitiva do processo (principal), debate-se a existência ou não da obrigação (an debeatur) e somente após solucionada esta crise nasce outra fase cognitiva (incidente) para a quantificação do valor da obrigação (quantum debeatur), chamada liquidação de sentença (CPC, art. 475-A e ss.).

\subsection{CONCLUSÃO PARCIAL: INTERPRETAMOS APENAS O PEDIDO?}

Pelo que vimos até o momento, podemos concluir que a divisão dos elementos da demanda em partes, pedido e causa de pedir, tal qual tratada no Capítulo 3, tem funções analíticas, auxilia na identificação do fenômeno e na sua compreensão. No entanto, quando tratamos de individualizar o objeto litigioso de um processo, teremos sempre de trabalhar com a junção - e não secção - destes elementos, é dizer, de um objeto único.

Por isso, a despeito de o Código de Processo Civil, reiteradamente, falar na interpretação do pedido (CPC, art. 286), decerto que devemos pressupor que este trata, não apenas do pedido, mas da interpretação de todo o conteúdo da demanda, pois o pedido somente faz sentido, individualiza-se, a partir de uma referência aos fatos concretos que

\footnotetext{
${ }^{260} \mathrm{Cf}$. Dinamarco, Instituições de direito processual civil, vol. II, item 444. 286:6.

${ }^{261}$ Cf. Theotônio Negrão, Código de processo civil e legislação processual em vigor, 2011, p. 413, Art.
} 
lhe dão ensejo, bem como às partes e ao direito aplicável (este útil para a identificação do fato essencial).

A interpretação do pedido não pode partir de uma leitura isolada da oração normalmente aportada ao fim da demanda - pela qual a parte designa sua vontade relativamente a um determinado bem da vida. O que importa, para os fins do pedido, é que esta vontade seja clara e manifesta, de modo que sua compreensão - à luz do que normalmente acontece naquele contexto - possa ser razoavelmente exigida do demandado e dos demais sujeitos que participam do contraditório.

Desejamos apenas pedido claro e vontade manifesta, sendo inoportuno exigir do demandante precisão científica na sua demanda. É razoável, inclusive, que a linguagem do "pedido" (i.e. daquela parte da demanda em que a vontade do demandante é expressa quanto à concessão de um bem da vida) seja lacônica, contendo frases do tipo "pede-se a condenação do réu em indenização", "pede-se a anulação do contrato", pede-se a declaração da inexistência da relação jurídica cambial", etc.

$\mathrm{Na}$ parte da petição que chamamos de "pedido", é comum que não exista o quantum debeatur. Pode, ainda, ocorrer desta parte ser formulada sem a indicação do an debeatur ou dos sujeitos por ele a serem afetados. E isto ocorre, pois a interpretação da demanda dever ser um ato holístico, de modo que as omissões presentes na enunciação de seu trecho final, que chamamos de "pedido" ou "requerimentos", sejam sanadas com informações presentes no restante deste ato linguístico.

Podemos recorrer à causa de pedir para identificar a "natureza" da relação de direito material que fundamenta o pedido e, desse modo, completar o an debeatur faltante do pedido. Podemos, do mesmo modo, recorrer ao valor ou à quantidade referida na causa de pedir para sanar a ausência de quantum debeatur presente na enunciação do "pedido". Por fim, podemos recorrer aos indivíduos elencados como parte no processo, ou mesmo como substituídos, para identificarmos os sujeitos da relação de direito material a serem afetados pelos efeitos da sentença. Mais disso veremos a seguir, quando tratarmos de casos práticos. 


\subsection{INTERPRETAÇÃO DO PEDIDO: CRITÉRIO TOPOLÓGICO?}

É usual que o pedido esteja designado na parte final da petição (veículo da demanda), seguindo inclusive - como espelhamento que é - a estrutura da sentença que visa a propiciar (CPC, art. 458, III). A demanda, como vimos, é um projeto de sentença, e o pedido está para demanda assim como o dispositivo está para a sentença.

Ocorre que, a despeito do que normalmente acontece, a lei não exige do demandante que seu pedido seja formulado ao fim ou em item designado nominal ou especificamente para tanto.

Todas as normas que regulam o formalismo do pedido e a interpretação de seu conteúdo têm relação com a necessidade de garantia do contraditório e da inércia (CPC. art. $2^{\circ}, 282$, IV e 286 e ss.). Desde que resguardados estes objetivos, i.e. desde que claramente formulado, de modo a propiciar plenamente o debate processual, não há prejuízo na formulação de pedido no corpo da demanda, sem a designação de tópico específico.

Seria possível cogitar aqui em tese a aplicabilidade da instrumentalidade das formas. Caso o demandante não houvesse indicado em sua petição um item final específico para o pedido, tendo o formulado no corpo da petição, de forma clara e inconfundível, não existiria qualquer prejuízo, não se podendo falar na inadmissibilidade da petição inicial (CPC, art. 154, 244 e 249). Ocorre que, tecnicamente, sequer seria possível falar nisto, pois não há dispositivo na lei a exigir da petição inicial um tópico final e específico intitulado "do pedido" ou "dos requerimentos".

É dizer, o requisito de admissibilidade da petição inicial é "conter pedido" (CPC, art. 282, IV), mas a lei não exige um local específico para tanto. Assim, a formulação de pedido "no corpo" da petição inicial sequer pode ser considerada irregularidade formal, ao passo que, por este simples motivo, não deve ensejar qualquer invalidade, sendo desnecessário o recurso à instrumentalidade das formas. Caso o pedido formulado seja impreciso ou incerto, o problema não será de natureza "topológica", mas um vício decorrente da sua própria constituição (CPC, art. 286).

Em precedente do Ministro Sávio Teixeira, foi fixado pelo Superior Tribunal de Justiça o entendimento pelo qual "o pedido é aquilo que se pretende com a instauração da demanda e se extrai a partir de uma interpretação lógico-sistemática do afirmado na 
petição inicial, recolhendo todos os requerimentos feitos em seu corpo, e não só aqueles constantes em capítulo especial ou sob a rubrica dos pedidos". ${ }^{262}$

Seguindo esta linha, a Corte declarou que "o pedido emana de interpretação lógico-sistemática da petição inicial, não podendo ser restringido somente ao capítulo especial que contenha a denominação dos pedidos". ${ }^{263}$ Neste último julgado, a Corte cuida de "ação de despejo" na qual, a despeito de pretender a cobrança de alugueres, o demandante teria se omitido em indicar tal pretensão na parte final de sua demanda e no "nome da ação". O precedente se fixou no sentido de que, sendo esta vontade indefectivelmente extraída do "corpo da petição" há pedido, autorizando a tutela jurisdicional.

Noutro caso, o Superior Tribunal de Justiça cuida de demanda na qual, ao fim, o autor requereu tão somente "pagamento de complementação de aposentadoria em face da invalidez", embora no corpo da petição tivesse manifestado claramente sua vontade quanto a outro bem da vida: "pagamento de pensão vitalícia". $\mathrm{O}$ aresto entendeu possível o acolhimento deste pedido, in verbis:

(...) 2. A pretensão deduzida em juízo não se limita a determinado capítulo da petição inicial, merecendo atenção do julgador tudo o que se pode extrair mediante interpretação lógicosistemática das razões apresentadas. Precedentes. 3. In casu, não se verifica a ocorrência de julgamento extra petita, uma vez que a sentença, ao condenar a ré ao pagamento de pensão vitalícia, ateve-se ao que pleiteado pelo autor no corpo da petição inicial, não obstante na sua parte final tenha requerido o pagamento de complementação de aposentadoria em face da invalidez. 4. Recurso especial a que se nega provimento. ${ }^{264}$

A jurisprudência dos tribunais estaduais segue a mesma linha. Em caso relevante, o Tribunal de Justiça do Distrito Federal declarou que "pode a sentença condenar a ré em quantias não pedidas pelo autor na conclusão final da petição inicial, se o pedido foi formulado no corpo da petição. A falta de primor da petição inicial não compromete o que foi suscitado pela parte em suas razões". ${ }^{265}$

Desse modo, observamos que a técnica processual não exige que o pedido assuma sempre um mesmo local da petição inicial, sendo formulado em tópico final. Basta apenas

\footnotetext{
${ }^{262}$ STJ, REsp 120299/ES, Rel. Min. Sálvio de Figueiredo Teixeira, DJ 21.9.98.

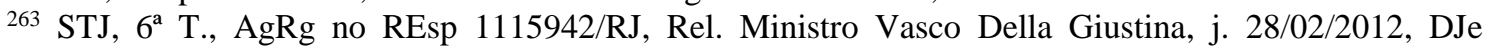
$12 / 03 / 2012$.

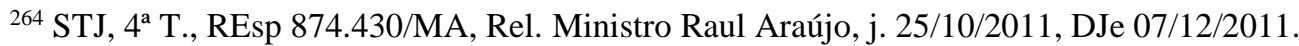

265 TJDF, $1^{a}$ T. C., Ap. 20020910033238, Relator Des. Roberval Casemiro Belinati, j. 23/09/2005, DJU 06/06/2006, p. 208.
} 
que a vontade seja clara, manifesta e inequívoca, de modo a propiciar a movimentação do Estado-juiz e a viabilizar o contraditório.

\subsection{INCERTEZA E INTERPRETAÇÃO RESTRITIVA DO PEDIDO}

Afirmamos acima que a exigência de interpretação restritiva do pedido não é uma norma geral. Ao contrário, aplica-se apenas aos casos em que os pedidos são formulados deficientemente, isto é, quando há incerteza significativa quanto ao seu conteúdo, com possível prejuízo para o contraditório. A questão é: como esta norma deve ser aplicada?

Mais uma vez, não é possível uma resposta, senão com o recurso à análise de casos concretos. A incerteza de um pedido depende, não apenas de sua enunciação, mas também do contexto em que formulado.

Em importante paradigma sobre o tema, o Superior Tribunal de Justiça cuidou de demanda na qual o autor, alegando-se motorista, pediu indenização pautada no salário mínimo vigente. $\mathrm{O}$ quantum debeatur não poderia ser precisamente delimitado apenas a partir da leitura do pedido, eis que não se poderia afirmar se o valor trataria do salário mínimo nacional ou do salário mínimo vigente para sua categoria.

No caso citado, julgou-se procedente o pedido, concedendo-lhe indenização pautada no salário mínimo de sua categoria. Em voto da lavra do Ministro Sálvio Teixeira, o recurso especial foi provido para reconhecer o julgamento ultra petita, ao entender que “se o pedido indenizatório postulou condenação calcada no salário mínimo, não se há de deferi-la com suporte no salário mínimo da categoria do autor (motorista), pena de violação da regra que veda o julgamento ultra petita". ${ }^{266}$

$\mathrm{O}$ aresto se pauta na circunstância de que o pedido deve ser compreendido à luz da causa de pedir, e que no caso concreto o demandante não teria se referido, em nenhum momento, ao salário de sua categoria na petição inicial, razão pela qual, existente dúvida sobre um ou outro, deve se optar por aquele entendimento que concede menor extensão ao pedido, nos termos do art. 293 do Código de Processo Civil.

Noutro precedente, e também partindo do conteúdo de toda a demanda (interpretação do pedido à luz da causa de pedir), a mesma Corte chegou à conclusão

\footnotetext{
${ }^{266}$ STJ, $4^{\text {a }}$ T., REsp 89.701/MG, Rel. Ministro Sálvio de Figueiredo Teixeira, DJ 22/06/1998, p. 82.
} 
oposta. Decidiu que, embora tenha a parte se limitado a enunciar no trecho da petição destacado como "do pedido" a anulação de ato administrativo desfavorável a servidor, seria possível interpretar que este "pedido" conteria, também, outro bem da vida, qual seja: “a recomposição integral dos direitos do servidor ilegalmente demitido". Para tanto, bastaria constatar que esta conclusão decorre da "interpretação lógico-sistemática da petição inicial”, isto é, da leitura do pedido a respeito do conteúdo da causa de pedir ou mesmo da identificação de outro pedido formulado "no corpo da petição inicial". 267

Notemos, nesse sentido, que a interpretação usada pelo Superior Tribunal de Justiça, tanto para restringir quanto para ampliar a extensão do pedido, não se pauta apenas na enunciação do pedido, ao fim da petição inicial ou mesmo no corpo dela, mas na demanda como um todo (pedido + causa de pedir). Concordamos que este é o único critério possível de interpretação do pedido e que, por se tratar de um ato de comunicação, seu sentido dependerá sempre das circunstâncias em que manifestada a vontade, tanto à luz da relação de direito material quanto à luz das normas processuais aplicáveis.

\subsection{Pedido E VONTAde TÁCITA}

Vimos até este momento que o pedido é um ato de vontade manifestado por meio de linguagem, e é pela sua interpretação que podemos identificar um conteúdo apto a individualizar o objeto litigioso do processo. A partir dessa premissa, questionamos: é possível identificar um pedido tacitamente?

$\mathrm{O}$ direito, em diferentes momentos, admite que a vontade de determinado sujeito seja interpretada, não a partir de um ato de fala que a enuncie diretamente, tal como "de acordo", "concordo", "comprometo-me", etc., mas a partir de um outro ato, tal como uma omissão relevante, que indiretamente autorizaria a interpretação pela concordância ou discordância. Isto ocorre, normalmente, por meio de presunções ou ficções jurídicas.

No processo, há diferentes casos em que a vontade da parte é interpretada a partir de condutas omissivas, i.e., implicitamente. Assim ocorre na ausência de impugnação específica, na revelia e na interposição de recurso parcial. Quanto à análise probatória e a convicção do juiz quanto aos fatos, o Código de Processo Civil chega a autorizar

${ }^{267}$ STJ, $1^{\text {a }}$ T., AgRg no REsp 1195680/RN, Rel. Ministro Napoleão Nunes Maia Filho, j. 17/11/2011, DJe $24 / 11 / 2011$. 
expressamente a formação de presunções hominis: “o juiz aplicará as regras de experiência comum subministradas pela observação do que ordinariamente acontece" (CPC, art. 335). No entanto, é impossível conceber a manifestação tácita quanto à pretensão para a tutela de um bem da vida, pois entender desse modo seria ignorar a relação entre pedido, inércia e contraditório (CPC, arts. $2^{\circ}, 128$ e 462). ${ }^{268}$

Referimo-nos acima que a certeza do pedido - e os critérios aplicáveis à sua interpretação - têm como objetivo resguardar as legítimas expectativas que podem vir a ser dele extraídas por parte dos diferentes sujeitos do processo, ao passo que somente a partir desta perspectiva será possível considerar que a todos foi concedida oportunidade de participação e que a todos foi conferida possibilidade de influenciar o resultado do processo (contraditório).

Um pedido tácito - cujo sentido seria presumido a partir de uma conduta ou de outro ato de fala - não teria condições de reunir grau de certeza mínimo, de modo a respeitar as exigências impostas pelo contraditório neste aspecto particular (contraditório quanto ao direito de obter um bem da vida).

Ademais, admitir um pedido tácito significaria incorrer no risco de ofensa à garantia da inércia. A ausência de um enunciado que autorize a compreensão e a identificação da vontade com um mínimo grau de certeza implica no risco de se concebê-la para além do desejado, ou mesmo de forma distinta.

Estas circunstâncias parecem ser observadas pela jurisprudência. Em julgado que trata de situação similar, o Superior Tribunal de Justiça entendeu que o pedido de condenação em pagamento de quantia não conteria, em si mesmo, a condenação em juros compensatórios não pleiteados expressamente. ${ }^{269}$ O problema, aqui, não trata da ausência do quantum debeatur, mas do próprio an debeatur, na medida em que não se poderia afirmar, a partir da simples leitura do pedido, se a vontade da parte se limitaria ao principal ou se o valor devido a título de acessórios estaria inserido nesta mesma vontade manifestada.

\footnotetext{
268 Tratando da vontade no processo civil, não positivamente, como na demanda, mas negativamente, no reconhecimento jurídico do pedido, Clito Fornaciari Jr. sustenta que "o reconhecimento jurídico do pedido deve ser expresso, não podendo resultar de meras ilações tiradas pelo juiz ou pelas partes". (Reconhecimento jurídico do pedido, 1977, p. 58).

${ }^{269}$ STJ, $2^{\mathrm{a}}$ T., REsp 905.719/RJ, Rel. Ministro Castro Meira, DJ 08/08/2007, p. 368.
} 
A Corte decidiu, ainda, noutro precedente, que "requerido o reconhecimento do direito ao gozo de férias (...) não há que se falar em omissão quanto ao pagamento de $1 / 3$ das férias não-gozadas" não pleiteado expressamente. ${ }^{270}$

Neste julgado, o raciocínio parece ser similar, ao passo que, embora exista proximidade entre os bens da vida, pois o adicional de 1/3 de férias decorre do direito ao gozo de férias, não se pode presumir que a vontade manifestada quanto a este abrangeria, de modo tácito, aquele. É razoável admitir a possibilidade de o demandante apenas pretender ver reconhecido seu direito a férias, sem desejar tutela condenatória ao adicional de $1 / 3$. Ademais, ausente manifestação de vontade inequívoca, não seria legítimo exigir do demandando que se defendesse e atuasse em contraditório a respeito de ser ou não devido o 1/3 de férias, com claro prejuízo para o devido processo legal.

Podemos concluir, portanto, que a lei processual, visando à segurança jurídica, exige uma manifestação inequívoca de vontade, um ato que enuncie expressamente a pretensão quanto a um bem da vida, para autorizar o rompimento da inércia e para obrigar o Estado-juiz a se manifestar. Um "pedido tácito" não cumpriria estes requisitos, não podendo ser aceito pela ordem jurídica.

\subsection{EXISTEM PEDIDOS IMPLÍCITOS?}

A par da categoria de "pedidos tácitos" que, conforme demonstramos acima, não deve ser admitida por nosso sistema jurídico, a doutrina cogita a existência dos chamados “pedidos implícitos”. Conforme Milton Paulo de Carvalho, "pedidos implícitos são os que, embora por sua natureza pudessem constituir pedidos autônomos, a lei considera compreendidos no pedido simples ou qualificado, ou presume neles compreendidos como decorrência objetiva da sucumbência processual". ${ }^{271}$

A doutrina assim cita como exemplo os chamados "pedidos implícitos" decorrentes da sucumbência processual $(i)$ o ressarcimento das despesas processuais, com custas, indenizações de viagem, diárias de testemunhas, honorários periciais, etc.; e (ii) a condenação ao pagamento dos honorários advocatícios. Além destes, são considerados pedidos implícitos (iii) a condenação relativa às prestações vincendas à época da

\footnotetext{
${ }^{270}$ STJ, $5^{\text {a }}$ T., EDcl no RMS 19.622/MT, Rel. Ministro Felix Fischer, DJ 30/10/2006, p. 334.
}

${ }^{271}$ Cf. Milton Paulo de Carvalho, Do pedido no processo civil, p. 101. 
propositura da demanda, nas obrigações de trato sucessivo ou execução continuada (CPC, art. 290) e (iv) o pedido de condenação em alimentos na ação declaratória de paternidade (Lei 8.560/92). ${ }^{272}$

No nosso modo de entender, os chamados "pedidos implícitos" não têm relação com a vontade das partes, não dependem dela, e por isso não são pedidos, mas apenas autorização da lei para que o juiz, em determinados casos, possa infringir a regra da inércia e da congruência, deferindo tutela não demanda pelas partes. Essa é a posição de Dinamarco:

"Conceitualmente, não há lugar para a existência de pedidos implícitos. Simplesmente, a lei e o sistema dispensam o pedido em algumas hipóteses, investindo o juiz do poder de pronunciar-se sobre juros, correção monetária, astreintes etc. ainda quando não hajam sido pedidos pelo demandante. Mais que exceções à regra da interpretação estrita, são ressalvas à proibição de conceder tutela extrapolante ao pedido feito (arts. 128 e 460). Todas elas contam com bom apoio legitimador da tendência universal a deformalizar o processo e da consciência da necessidade de promover a efetividade da tutela jurisdicional e do acesso à justiça (particularmente as exceções relacionadas com as obrigações de fazer ou de não-fazer); mas falar em pedido implícito é valer-se arbitrariamente de uma desnecessária ficção legal, porque basta reconhecer que todos esses são casos em que o pedido é dispensado, não havendo por que fingir que ele haja sido deduzido". ${ }^{273}$

É importante notar que esta possibilidade de concessão de bens da vida ex officio não ofende o princípio do contraditório. Exatamente por existir previsão legal, e pelo fato de não ser possível se escusar do conhecimento da lei, os demais sujeitos envoltos no contraditório têm conhecimento prévio do dever de o juiz conceder tais bens da vida de ofício, sabendo da possibilidade desta concessão e, portanto, tendo o ônus de se manifestar a este respeito.

No mais, conforme Bedaque, não há vedação constitucional para que o Estado, visando a assegurar uma ordem jurídica justa, especialmente relacionada aos escopos do processo, possa relativizar a regra da inércia, concedendo ao juiz a possibilidade de tutelar bem da vida de ofício:

${ }^{272}$ Elias sustenta, nesse sentido, que esta regra cuidaria de "interpretação extensiva do pedido" (Cf. "As reformas processuais e o princípio da congruência entre sentença e pedido", RePro 158, p. 52). Não concordamos com esta afirmação, pois não há o que se interpretar a respeito de um não-ato, um não-pedido. A regra cuida claramente de uma exceção à inércia e à congruência, de uma autorização para que o juiz conceda a tutela sem pedido.

${ }^{273}$ Cf. Dinamarco, Instituições de direito processual civil, vol. III, item 455. 
“O que não se admite é o legislador ordinário opor óbices ao acesso à Justiça. Nada impede, todavia, seja desconsiderada a regra da inércia, por questões de política legislativa ou conveniência, permitindo-se ao juiz, em determinadas situações, dá início ao processo sem provocação das partes". ${ }^{274}$

Assim, o Código de Processo Civil relativiza a garantia constitucional da inércia, em prol de outros valores constitucionais, como a efetividade do processo e o escopo jurídico, autorizando o juiz a impor ao sucumbente a obrigação de pagar quantias relativas às despesas processuais, aos honorários de sucumbência (CPC, art. 20 e $\S$ ) e à litigância de má fé (CPC, art. 18). Despesas estas que nascem com o processo e que, portanto, são posteriores à relação material conflituosa.

A lei, igualmente visando a uma maior pacificação do litígio e considerando suas circunstâncias específicas (princípio da adaptabilidade), autoriza que nas demandas pautadas em relações continuativas, o juiz esteja autorizado a condenar o réu ao pagamento de parcelas ainda não vencidas na data da propositura da demanda. Ao fazê-lo, propicia a economia processual e evita a necessidade de ajuizamento de uma nova demanda.

As exceções à inércia e a congruência são pontuais e se justificam por exigências das relações de direito material, às quais se dirige a atividade jurisdicional, ganhando assim legitimidade na medida em que servem aos escopos do processo: justiça (escopo jurídico) e pacificação (escopo social).

\subsection{OUTROS “PEDIDOS IMPLÍ́CITOS” NA JURISPRUDÊNCIA}

Além da concepção tradicional de "pedidos implícitos" que, conforme demonstramos acima, de um modo geral cuida de exceções legais ao princípio da inércia, devidamente justificadas pelo formalismo processual e pelos escopos do processo, especialmente a jurisprudência cogita a possibilidade de existirem "pedidos implícitos" de outra natureza; não aqueles previstos pela lei, mas outros que serem extraídos a partir de uma interpretação "logico-sistemática" da demanda.

A primeira hipótese cuida da possibilidade de condenação "implícita" ao pagamento de juros de mora e correção monetária, reconhecida pacificamente pela

\footnotetext{
${ }^{274} \mathrm{Cf}$. Bedaque, "Os elementos objetivos da demanda à luz do contraditório", Causa de pedir e pedido no
} processo civil, p. 25. 
jurisprudência sob a rubrica de "pedido implícito", especialmente pelo Superior Tribunal de Justiça.

Conforme vimos acima, quando falamos da condenação em despesas processuais, honorários advocatícios ou mesmo quando falamos da condenação a parcelas vincendas (sem um pedido para tanto), estamos tratando de uma autorização expressa da norma processual, para que o juiz vença a inércia e conceda tutela jurisdicional ex officio. Ocorre que, quando tratamos do pagamento de juros e correção monetária, estamos cuidando da interpretação do pedido formulado (condenação) à luz do que determinam as regras de direito material, e não de uma autorização especial para rompimento da correlação.

A jurisprudência do Superior Tribunal de Justiça, nesse sentido, a despeito de falar em "pedidos implícitos", admite a possibilidade de acrescer ao valor principal juros de mora e correção monetária, ainda que sem menção expressa a estes elementos no pedido, por entender que estes seriam parte integrante do valor da obrigação. ${ }^{275}$

Observemos: não se está aqui a falar que a lei processual aceitaria a concessão destes "bens da vida" independentemente de pedido, mas que, quando há pedido condenatório em quantia, a estes devem se considerar incorporadas as verbas relativas aos juros de mora e à correção monetária, por estes serem - à luz do direito material, e não do processo - parte integrante do montante principal.

Tratamos, portanto, de uma norma de interpretação do pedido com referência no seu contexto normativo substancial, e não de um "pedido implícito" ou mesmo de uma exceção à correlação, nos termos do que determina o art. 293 do Código de Processo Civil: “Os pedidos são interpretados restritivamente, compreendendo-se, entretanto, no principal os juros legais".

Do mesmo modo que um pedido para entrega de um bem imóvel, delimitado por suas características essenciais, importa na obrigação de entregar este mesmo bem com seus respectivos acessórios, o pedido de condenação em quantia em dinheiro deve, independentemente da menção a seus acessórios, importar na inclusão destes. A questão, portanto, decorre do direito material (princípio da gravitação), que considera o principal e os acessórios um bem só, não sendo um problema da técnica processual (CC, art. 404 e 406).

\footnotetext{
${ }^{275}$ Nesse sentido decidiu o Superior Tribunal de Justiça: “Os juros legais são acessórios do principal, motivo pelo qual, embora omisso o pedido inicial ou a sentença condenatória, consideram-se implícitos e devem ser incluídos na conta de liquidação, ainda que homologado cálculo anterior, não implicando esta inclusão em ofensa a coisa julgada”. (STJ, 4 ${ }^{a}$ T., REsp 402724/SP, Rel. Ministro Luis Felipe Salomão, j. 06/04/2010).
} 
A segunda hipótese de falsos "pedidos implícitos" é extraída basicamente de julgado já citado de relatoria do ministro Sálvio de Figueiredo Teixeira que, de acordo com as premissas da presente tese, admitiu a necessidade de uma interpretação do pedido a partir do contexto linguístico em que emitido, e não somente da parte rotulada como tal na petição inicial. ${ }^{276}$

No recurso especial 222.644/RS, a Corte reconheceu que, em petição inicial que narra acidente de trânsito e pede reparação por danos pessoais, estaria implícito o pedido de indenização por danos morais, podendo assim ser conferida tutela jurisdicional referente a este bem da vida, não expressamente enunciado. ${ }^{277} \mathrm{O}$ trecho da petição do qual o acórdão entende estar implícito o pedido condenatório em danos morais é o seguinte:

“(...) Como podemos ver, o acidente ocorreu por culpa exclusiva da Ré, pois o acidente foi ocasionado por imperícia, imprudência em avançar uma preferencial, ocasionado danos pessoais a diversas pessoas, mas em especial à Autora. 5 - A autora ficou impossibilitada de continuar sua vida normal por mais de 200 dias, podendo ficar com sequelas permanentes requerendo assim uma indenização de 500 salários mínimos, pelos danos causados e ressarcimento de suas despesas".

O problema da interpretação da demanda é complexo, conforme reiteradamente reconhecemos neste trabalho, e não há dúvidas de que o acórdão citado tentou fixar parâmetros para justificar sua interpretação a respeito do conteúdo da demanda, especialmente quando declara que:

\footnotetext{
“(...) III - Considera-se dano à pessoa toda ofensa dirigida contra sua integridade física ou incolumidade moral, a acarretar-lhe consequências desfavoráveis como entidade somática e psíquica. IV - Em ação de reparação de danos, referindo-se o autor que do ato ilícito resultou danos pessoais, a sentença condenatória pelos danos morais não foge aos limites do pedido”.
}

\footnotetext{
${ }^{276}$ Cf. STJ, 4 a T., Resp 120.299/ES, Rel. Min. Sálvio de Figueiredo Teixeira, DJ de 21.9.1998.

277 "Responsabilidade civil. Acidente de trânsito. Ação de indenização por danos pessoais e materiais julgada procedente. Recurso especial. Alegação de ofensa aos arts. 293, 459 e 460, do Código de Processo Civil. Julgamento Extra petita. Inocorrência. Dano pessoal. Configuração. I - Não ocorre julgamento extra ou ultra petita na hipótese em que o tribunal reconhece os pedidos implicitamente formulados na inicial. II - O princípio de que os pedidos são interpretados restritivamente não impede que os implícitos sejam conhecidos. III - Considera-se dano à pessoa toda ofensa dirigida contra sua integridade física ou incolumidade moral, a acarretar-lhe conseqüências desfavoráveis como entidade somática e psíquica. IV - Em ação de reparação de danos, referindo-se o autor que do ato ilícito resultou danos pessoais, a sentença condenatória pelos danos morais não foge aos limites do pedido. V - Recurso especial não conhecido. (REsp 222.644/RS, Rel. Ministro ANTÔNIO DE PÁDUA RIBEIRO, TERCEIRA TURMA, julgado em 19/05/2005, DJ 13/06/2005, p. 287)
} 
A Corte reconheceu que, no caso, há a narrativa de um fato que juridicamente teria aptidão de configurar dano moral, ao lado de uma conduta supostamente ilícita, nos termos do art. 927. O pedido, conforme relata o acórdão, teria sido no sentido de que a parte fosse indenizada por danos pessoais, danos estes que - conforme estudo doutrinário citado no texto da decisão - em seu sentido legal incluiria a indenização por danos morais. Estes foram os critérios interpretativos usados pelo Tribunal, levando-se em consideração o sentido das expressões usadas no ato de demandar e o contexto no qual manifestado este ato.

Não é nossa intenção aqui avaliar se, do ponto de vista do direito material, a expressão "danos pessoais" seria suficiente para incluir o sentido mais claro de danos morais. Tampouco desejamos avaliar se a mera expressão "danos pessoais" seria suficiente para permitir que o demandado identifique que a vontade da parte seria no sentido de ser indenizada em danos morais. O que importa - para nossos objetivos - é que o acórdão respondeu positivamente a estas questões. E desse modo, tendo o feito, a Corte se equivoca ao chamar a condenação em "danos morais" de "pedido implícito".

E isto porque, ao invés de tratar de um pedido implícito, o Superior Tribunal de Justiça simplesmente interpretou o conteúdo do pedido formulado, qual seja, "condenação em danos pessoais", e afirmou que esta expressão pressupõe a inclusão de danos morais em seu conteúdo, conforme critério do direito material. Trata, por isso, da vontade manifesta pela parte em palavras, de um ato linguístico que tem um conteúdo e que somente pode ser identificado a partir de um juízo interpretativo.

\subsection{5. “EXCESSO DE CRIATIVIDADE” NA INTERPRETAÇÃO DO PEDIDO}

Vimos que os pedidos e as demandas devem ser interpretadas de acordo com a causa de pedir, com as normas aplicáveis e de acordo com o contexto social no qual originado o conflito de interesses (crise jurídica), sempre a partir da perspectiva do homem médio.

A jurisprudência, corretamente, entende a demanda como um ato racional e que a vontade manifestada deve ser sempre interpretada de modo sistemático, não devendo o juiz pautar-se apenas na linguagem enunciada ao fim da petição sob o rótulo "dos pedidos" ou "dos requerimentos". 
Ocorre que, distanciando-se destas exigências, alguns excessos vêm sendo cometidos pelos tribunais, ao argumento de se buscar maior efetividade do processo. Querse ampliar para além da vontade das partes (e do contraditório) a extensão do pedido, ao argumento de que existiriam bens da vida que implicitamente poderiam ser extraídos a partir do pedido de outros.

Retrata esta situação entendimento jurisprudencial que se firmou a respeito das demandas que visam rescisão de contrato. Nestes casos, a jurisprudência declara que, uma vez formulado o pedido constitutivo negativo, seria implícito o pedido condenatório à devolução de eventuais valores pagos em razão do contrato. Para decidir desse modo, os precedentes se pautam no argumento de que a restituição de parcelas pagas em função do contrato rescindido seria uma decorrência imposta pela própria norma de direito material e que, por este motivo, não constituiria ofensa à regra da correlação. Vejamos:

"ao determinar que a recorrente restituísse as parcelas do preço entregues pelos recorridos, os quais já possuíam, desde a sentença, a obrigação de restituir o imóvel em cuja posse se encontravam, o Tribunal de origem nada mais fez do que concretizar a eficácia restitutória da resolução do contrato de promessa de compra e venda decretada pela sentença. Consequentemente, não houve julgamento ultra petita, não se consubstanciando qualquer violação dos arts. 128, $459 \mathrm{e}$ 460 do CPC (...) Assim, se o credor, na petição inicial, postula a resolução do contrato, não há a necessidade de que o devedor, na contestação ou em reconvenção, requeira a devolução das prestações entregues ao credor, a qual pode e deve ser determinada de ofício pelo juiz como decorrência lógica da decretação de resolução do contrato". 278

\footnotetext{
278 Vejamos trecho do aresto: "Decretada a resolução do contrato de promessa de compra e venda, a determinação de restituição aos promitentes compradores das parcelas do preço pagas ao promitente vendedor pode ser determinada de ofício pelo juízo ou exige a iniciativa da parte mediante pedido expresso formulado na contestação ou reconvenção? (...) Pelo aspecto subjetivo, a resolução constitui, como destaca Araken de Assis (Resolução do contrato por inadimplemento. $4^{\mathrm{a}}$ ed. rev. e atual. São Paulo: Editora RT, 2004), direito formativo extintivo, ou direito potestativo, ocasionando, com o seu exercício, a desconstituição da relação obrigacional e a liberação de credor e devedor de suas obrigações (eficácia liberatória). Predomina, pois, na resolução, a desconstituição do contrato e, consequentemente, da relação obrigacional dele nascida. Nada obstante, resulta também da resolução do contrato o surgimento de uma nova relação obrigacional, chamada relação de liquidação, pela qual tanto o credor como o devedor devem restituir as prestações recebidas durante a execução do contrato (eficácia restitutória) e pela qual o devedor culpado pelo inadimplemento deve indenizar o credor. A respeito da eficácia restitutória resultante da relação de liquidação, a seguinte lição do eminente Ministro Ruy Rosado de Aguiar Junior, exposta em sede doutrinária (Extinção dos contratos por incumprimento do devedor [Resolução]. Rio de Janeiro: Aide, 1991, p. 254): Resolvida a relação obrigacional, surge a relação de liquidação, na qual serão tratados os direitos do credor e do devedor a restituição das prestações já efetivadas e o direito do credor à indenização por perdas e danos (art. 1092, parágrafo único, do Código Civil). PONTES DE MIRANDA atribui a origem dessa relação exclusivamente à resolução, que desconstituiu os efeitos do negócio jurídico, e não ao fato do inadimplemento do contrato, que está extinto, nem ao enriquecimento sem causa, pois o devedor deve restituir tudo, não só o enriquecimento injustificado. Mais aceitável, porém, na perspectiva dinâmica da obrigação, considerar-se, como LARENZ, que a relação obrigacional não fica totalmente anulada, persistindo dela os deveres de diligência e de indenização de danos. Os direitos e deveres que integram a relação de
} 
Este entendimento não se coaduna com as premissas estabelecidas na presente tese. A pretensão de extinguir uma relação contratual não se confunde com a pretensão de

liquidação tem sua causa imediata na resolução, mas esta é apenas uma fase do desdobramento da relação obrigacional. A eficácia restitutória ou a obrigação de restituir as prestações recebidas - atribuída tanto ao credor como ao devedor - constitui, portanto, consequência natural e indissociável da resolução do contrato, ao lado da eficácia liberatória e da obrigação do devedor de indenizar as perdas e danos comprovadamente sofridas pelo credor. Assim, se o credor, na petição inicial, postula a resolução do contrato, não há a necessidade de que o devedor, na contestação ou em reconvenção, requeira a devolução das prestações entregues ao credor, a qual pode e deve ser determinada de ofício pelo juiz como decorrência lógica da decretação de resolução do contrato. Importante ressaltar ainda que o credor, da mesma forma e em decorrência do mesmo pedido de resolução, também possui o direito ao recebimento de eventuais prestações entregues ao devedor, o que, na ação de resolução do contrato de compra e venda, se manifesta com a sua reintegração na posse do imóvel. Como se pode ver, a reciprocidade existente nos contratos bilaterais se mantém mesmo depois da sua resolução, na chamada relação de liquidação, de modo que a obrigação de restituir do credor (devolução das parcelas do preço) e a obrigação de restituir do devedor (devolução da coisa) são causa uma da outra. A respeito da controvérsia, a jurisprudência da Terceira e da Quarta Turma deste STJ sempre foi no sentido da desnecessidade, na resolução da compra e venda, da iniciativa da parte ré para que lhe seja assegurada a devolução das parcelas do preço, embora os precedentes encontrados não sejam recentes, in verbis: PROMESSA DE COMPRA E VENDA - RESCISÃO - DEVOLUÇÃO DO QUE FOI PAGO. RECONHECIDO QUE O PROMITENTE COMPRADOR TEM DIREITO A DEVOLUÇÃO DO QUE FOI PAGO, POSTO QUE NEGADO O PLEITO DO AUTOR, NO SENTIDO DA PERDA DAS IMPORTÂNCIAS CORRESPONDENTES, AS PARTES HAVERÃO DE SER REPOSTAS NO ESTADO ANTERIOR. POSSIBILIDADE DE DETERMINAR-SE A DEVOLUÇÃO, SEM NECESSIDADE DE RECONVENÇÃO. (REsp 49.396SP, Rel. Ministro EDUARDO RIBEIRO, TERCEIRA TURMA, julgado em 1605/1995, DJ 12/06/1995, p. 17624) PROCESSO CIVIL. RESCISÃO DE CONTRATO DE PROMESSA DE COMPRA E VENDA PROPOSTA PELO VENDEDOR. DEVOLUÇÃO DE PARTE DAS PARCELAS DO PREÇO. DESNECESSIDADE DE RECONVENÇÃO. Na ação de rescisão de contrato de promessa de compra e venda, proposta pelo vendedor contra o comprador inadimplente, o juiz pode ordenar a devolução de parte das parcelas do preço independentemente de reconvenção. Recurso especial conhecido e provido. (REsp 97.538SP, Rel. Ministro ARI PARGENDLER, TERCEIRA TURMA, julgado em 1004/2000, DJ 0805/2000, p. 89) PROMESSA DE COMPRA E VENDA. Parcelamento do solo. Resolução. Restituição. CDC. Reconvenção. - O CDC se aplica à relação de consumo estabelecida entre a empresa que comercializa imóveis loteados urbanos e o promissário comprador, operação que é regulada, no que tem de específico, pela legislação própria (Lei 676679). - Resolvido o negócio, cabe a restituição das parcelas mensais pagas pelos promissários compradores, que já perderam o sinal em favor da promitente vendedora. A decisão sobre a restituição das partes à situação anterior integra resolução judicial do contrato e deve ser objeto de decisão do juiz ainda que não tenha sido requerido pela parte na contestação ou em reconvenção. Recurso não conhecido. (REsp 300721/SP, Rel. Ministro RUY ROSADO DE AGUIAR, QUARTA TURMA, julgado em 0409/2001, DJ 29/10/2001, p. 210) CIVIL E PROCESSUAL. PROMESSA DE COMPRA E VENDA DE LOTE. PAGAMENTO EM PRESTAÇÕES. INADIMPLEMENTO DOS RÉUS. AÇÃO DE RESCISÃO MOVIDA PELA VENDEDORA. DESFAZIMENTO DA RELAÇÃO. DEVOLUÇÃ̃O DAS PARCELAS PAGAS COM RETENÇÃO DE DETERMINADO PERCENTUAL PARA FAZER FRENTE A DESPESAS DA CREDORA. CONTESTAÇÃO OMISSA A RESPEITO. PRECLUSÃO INEXISTENTE. CONSEQÜÊNCIA INERENTE À RESCISÃO. CPC, ART. 300. OFENSA NÃO IDENTIFICADA. I. Em havendo rescisão do compromisso de compra e venda, o desfazimento da relação contratual implica, automaticamente, como decorrência lógica e necessária, na restituição das prestações pagas, reservada uma parte, que fica deduzida, em favor da alienante, para ressarcir-se de despesas administrativas, sendo desnecessário que tal devolução conste nem do pedido exordial (quando o autor é o vendedor), nem da contestação (quando o autor é o comprador), por inerente à natureza da lide. II. Recurso especial não conhecido. (REsp 500038SP, Rel. Ministro ALDIR PASSARINHO JUNIOR, QUARTA TURMA, julgado em 2204/2003, DJ 25/08/2003, p. 322). No caso concreto, ao determinar que a recorrente restituísse as parcelas do preço entregues pelos recorridos, os quais já possuíam, desde a sentença, a obrigação de restituir o imóvel em cuja posse se encontravam, o Tribunal de origem nada mais fez do que concretizar a eficácia restitutória da resolução do contrato de promessa de compra e venda decretada pela sentença. Consequentemente, não houve julgamento ultra petita, não se consubstanciando qualquer violação dos arts. 128, 459 e 460 do CPC. Ante o exposto, nego provimento ao recurso especial. É o voto. (cf. STJ, $3^{\mathrm{a}}$ T., Resp n. ${ }^{\circ} 1286144$ / MG, Relator Paulo de Tarso Sanseverino, j. 07/03/2013). 
reaver quantias pagas em função deste contrato. Mais do que isso, não é suficiente o contraditório que se estabelece quanto ao fato de existir, ou não, o direito potestativo à extinção do contrato para que se possa discutir se existe, ou não, o direito de reaver quantias. $^{279}$

Embora tenhamos afirmado que a tutela constitutiva negativa importa no dever geral de respeito a situação produzida pela sentença, de extinção da relação de direito material, não entendemos que a obrigação de pagar quantia - neste caso concreto - possa ser concebida como parte integrante deve dever genérico. Isto porque, o conteúdo do pedido só pode ser compreendido à luz do contraditório, e a questão relativa à devolução de quantia não foi submetida ao debate entre as partes, e por isso, encontra-se fora do objeto litigioso do processo (cf. item 3.7).

Conforme nos manifestamos em outras hipóteses, caso a lei estipulasse expressamente que o juiz, em tais casos, estaria autorizado a romper a inércia e a conceder a restituição de valores pagos, mesmo sem pedido, poderíamos supor que as partes possivelmente afetadas por esta "questão" teriam o ônus de reagir a respeito da possibilidade, i.e. exercitarem o contraditório plenamente. Ocorre que, em nosso sistema jurídico, não há previsão como esta, de modo que conceder restituição de quantias como “pedido implícito" à rescisão de contrato significa inviabilizar o contraditório e ofender as garantias constitucionais do processo.

Outro caso que trata de problema similar diz respeito a entendimento jurisprudencial no sentido de que o pedido de reintegração de servidor público demitido indevidamente traria consigo o pedido implícito de pagamento das remunerações não recebidas no curso do afastamento. Assim manifestou-se o Superior Tribunal de Justiça:

“1. A decisão que declara a nulidade do ato e determina a reintegração de servidor público ao cargo de origem opera efeitos ex tunc, ou seja, restabelece exatamente o status quo ante, de modo a garantir ao servidor o pagamento integral das vantagens pecuniárias do cargo anteriormente ocupado. 2. Como o pagamento dos vencimentos é mera consequência do ato de reintegração do servidor público, inexiste, na hipótese, excesso à execução. 3. Não viola os arts. 128, 293 e 460 do Código de Processo Civil a decisão que interpreta, de forma ampla, o pedido formulado na peça

\footnotetext{
279 Tratando de caso muito similar, o Superior Tribunal de Justiça entendeu que "há julgamento fora dos limites do pedido se, na apreciação da demanda voltada unicamente à resolução do contrato, há condenação a indenizar pelo uso da coisa objeto da avença" (STJ, $3^{a}$ T., REsp 952.971, Rel. Min. Nancy Andrighi, j. 17.12.2009). Cf. Theotonio Negrão, Código de processo civil..., $43^{\mathrm{a}}$ ed., p. 520.
} 
vestibular, pois o pedido é o que se pretende com a instauração da demanda e se extrai da interpretação lógico-sistemática da postulação inicial”. ${ }^{280}$

A situação narrada é similar à anterior, pois ainda que pudéssemos afirmar - à luz do direito material - que o direito ao recebimento da remuneração pelo período não trabalhado fosse uma "consequência lógica" do direito à reintegração, não seria possível admitir que o pedido de pagamento de quantia em dinheiro seria implícito à obrigação de fazer $c / c$ declaração de nulidade do ato administrativo, efetivamente demandada pela parte.

Cuidamos de dois bens da vida distintos. A vontade quanto a um não implica presunção de que foi manifestada vontade quanto a outro. Mais do que isso: tendo se estabelecido demanda apenas quanto ao pedido de "reintegração" não é possível se exigir do réu que reaja e eficazmente e estabeleça contraditório quanto (i) ao direito de receber quantias em dinheiro; (ii) ao quantum que efetivamente seria devido. Assim, não existindo pedido de pagamento de quantia, a Corte não apenas ofenderia o princípio da inércia, mas também, e fundamentalmente, o princípio do contraditório, ao conferir tutela condenatória ao pagamento de quantia não demandada pela parte.

Seguindo as premissas da instrumentalidade do processo, entendemos que a efetividade e o processo civil de resultados não pode ser buscado a qualquer custo, sendo reprovável o "excesso de criatividade" dos tribunais na interpretação dos pedidos, como um expediente ilegal de concessão de tutela não demandada pela parte e não autorizada expressamente pela lei.

4.16. QUANTIDADE E QUALIDADE DO PEDIDO: É POSSÍVEL ESTABELECER DISTINÇÕES CLARAS?

Até o presente momento duas premissas restaram muito claras. A primeira é no sentido de que o pedido deve ser interpretado sempre à luz do contraditório, dos demais elementos da demanda e do contexto no qual elaborado e que a interpretação restritiva deve se limitar aos casos de imprecisão, de incerteza no pedido. A segunda é no sentido de que esta possibilidade de interpretação "lógico-sistemática" não deve ser confundida com

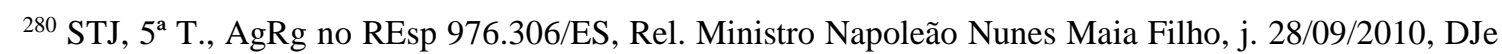
$25 / 10 / 2010$. 
uma liberdade irrestrita de criação, tendo em vista as fundamentais exigências de segurança e de previsibilidade que vinculam a interpretação o pedido, especialmente do ponto de vista do contraditório.

Diante destas constatações, pergunta-se: poderia o juiz, considerando o contexto no qual ocorreu a manifestação de vontade e as especificidades da relação de direito material, interpretar o pedido de forma "ampliativa", de modo a admitir a concessão de bem da vida distinto, embora de consequências menos drásticas, em hipótese análoga a procedência parcial?

Para melhor esclarecermos a situação, trataremos de situações concretas. Em demanda que visa a impedir poluição de fábrica, foi formulado pedido de fechamento. $\mathrm{O}$ juiz, identificando que o fechamento não é medida adequada, mas reconhecendo que o mesmo "escopo" (qual seja: "evitar a poluição") poderia ser atingido com a instalação de filtro, poderia interpretar ampliativamente o pedido para, julgando-o parcialmente procedente, determinar a instalação do equipamento e manter o funcionamento da fábrica?

Acreditamos que esta medida, inexoravelmente, importaria na alteração do objeto litigioso do processo. A demanda incialmente conteria pedido condenatório de obrigação de não fazer (proibição de funcionamento), enquanto que o bem da vida concedido pelo juiz seria muito distinto, qual seja, uma obrigação de fazer representada pela instalação de filtro.

Ainda que possamos afirmar que $(i)$ ambas as medidas visam ao mesmo escopo (evitar a poluição); (ii) o fechamento da fábrica seria medida mais grave e eficaz que a instalação de filtro (e.g. o fechamento seria capaz de evitar totalmente a poluição, enquanto que a instalação de filtro apenas seria capaz de reduzi-la), não poderíamos falar em meras intensidades distintas na concessão da tutela: não há medidas que se diferenciam pela quantidade (quantum debeatur), mas pela qualidade (an debeatur). Por isso, a instalação de filtro não significa "procedência parcial" frente ao pedido de fechamento da fábrica, mas tutela distinta da pleiteada.

Ainda que a causa de pedir jurídica se paute em princípios ou regras jurídicas de moldura bem ampla, não há dúvidas de que os fatos que justificariam uma medida seriam distintos dos fatos que justificariam a outra, pois deveriam existir argumentos técnicos que demonstrariam sua adequação. Com efeito, determinando a instalação de filtro o juiz atuaria fora de seus limites e ofenderia o contraditório (extra petita), de modo que não haveria neste caso tão somente uma ofensa à congruência, mas também restrições à ampla defesa e ao contraditório. 
Esta posição, no entanto, não vem sendo adotada pela jurisprudência em casos similares ao presente. A jurisprudência tende a admitir uma desconstrução do sentido do pedido, uma verdadeira busca de uma "essência abstrata", como "evitar poluição", "destinar número de vagas", "resolver a questão material da vítima" para contorcer o conteúdo da específica manifestação da parte, e.g. fechar a fábrica, anular o edital ou pagar indenização por perdas e danos, e conceder algo distinto, que se julga ser mais justo e adequado ao caso concreto.

O Superior Tribunal de Justiça cuidou de demanda que visava à anulação de edital de processo seletivo para escola pública de educação tecnológica. A causa de pedir pautava-se na afirmação de que a lei preveria 600 vagas e que o edital deveria ser considerado nulo por apenas prever 120 vagas. Nada além disso foi pleiteado, apenas a anulação.

A sentença, no entanto, julgou parcialmente procedente o pedido. Entendeu que o pedido de anulação seria descabido, mas que o problema (escopo de "destinar o número de vagas") poderia ser sanado com a determinação de que fossem disponibilizadas 600 e não apenas 120 vagas. Houve assim um pedido constitutivo negativo e duas tutelas: uma constitutiva positiva (modificação do número de vagas do edital) e uma condenatória, obrigando a instituição a disponibilizar mais vagas (fazer algo).

Ao analisar a questão, à luz dos artigos 128 e 460 do Código de Processo Civil, o Superior Tribunal de Justiça solucionou-a erradamente, sob a tese de estar simplesmente interpretando o pedido de anulação como se fosse uma manifestação de vontade abstrata de "resolver o problema das vagas" de modo a sustentar que a concessão das tutelas distintas não representaria quebra da congruência. Vejamos:

“1. Os impetrantes pediram a anulação do edital de abertura do processo seletivo de 1999, para ingresso no ensino médio do Centro Federal de Educação Tecnológica de Minas Gerais, em razão de não ter sido aprovado em conformidade com as normas estatutárias e regimentais, assim também por ter reduzido a oferta de vagas, de 600 para 120. A segurança foi concedida, em parte, apenas para, considerando ilegítima a redução, assegurar a convocação dos candidatos aprovados, para o preenchimento das 600 vagas inicialmente previstas. 2. Não incorre em vício a sentença que, analisando a controvérsia, concede menos do que pedido, uma vez que "(...) o exame do pedido engendrado no recurso de apelação dentro dos limites postos pelas partes não incide no vício 'in procedendo' do julgamento 'ultra' ou 'extra petita' e, consectariamente, afasta a suposta ofensa aos arts. 460 e 461, do CPC (...)" (REsp 904.548/PR, Rel. Ministro LUIZ FUX, 
PRIMEIRA TURMA, julgado em 4/12/2008, DJe 17/12/2008). 3. Agravo regimental a que se nega provimento". ${ }^{281}$

Noutro caso similar, a Corte entendeu que, em demanda tributária, com pedido declaratório de nulidade de inscrição em dívida ativa, o juiz - identificando não haver fundamentos para a nulidade do ato administrativo - poderia conceder tutela supostamente inferior, determinando a redução de multa ilegalmente cobrada pelo fisco. O que impressiona nesse caso é a simplicidade da fundamentação, que autorizaria a concessão de um bem da vida bem distinto daquele demandado pela parte:

“(...) a recorrida formulou pedido para "declarar a nulidade da inscrição da dívida ativa em UFIRs, e como consequiência ser declarada insubsistente a penhora" (fl. 4). De tal forma deduzido, o pedido de nulidade da inscrição da dívida ativa engloba a extinção da multa moratória, não sendo com ela incompatível a sua redução, de acordo com a máxima de que "o acessório segue o principal". Conduzindo o raciocínio de acordo com o referido princípio, concluo pela inexistência de ofensa ao art. 460 do CPC. Assim, entendo que o Tribunal, diante do que foi requerido pelo contribuinte, estava autorizado a atender parcialmente o pleito, para reduzir o valor da multa". ${ }^{282}$

Não entendemos que o Código de Processo Civil tenha concedido possibilidades tão amplas de criação de pedidos pelo juiz. Sob a rubrica de "interpretar" o pedido, o juiz não pode ignorar as exigências de segurança jurídica e previsibilidade correlatas ao formalismo processual, sob pena de violar as garantias constitucionais do processo aplicáveis.

281 STJ, 6 ${ }^{\mathrm{a}}$ T., AgRg no REsp 848.837/MG, Rel. Ministro FERNANDES, SEXTA TURMA, j. 02/08/2012, DJe 15/08/2012. O mesmo entendimento foi manifestado no julgamento do AgRg no Recurso Especial $\mathrm{n}^{\circ} 1.118 .704$, embora neste caso a Corte tenha se pautado em dois fundamentos simultâneos. O caso cuida de demanda com pedido de indenização por lucros cessantes, tendo a corte deferido o pagamento de pensão mensal. “O pedido é aquilo que se pretende com a instauração da demanda e se extrai a partir de uma interpretação lógico-sistemática do afirmado na petição inicial, recolhendo todos os requerimentos feitos em seu corpo, e não só aqueles constantes em capítulo especial ou sob a rubrica dos pedidos. 2. In casu, há inquestionável correlação lógica entre a causa de pedir e os pedidos formulados na petição inicial. Ademais, é dado ao Juiz deferir pretensão que, conquanto não formulada expressamente, represente um minus em relação ao que perseguido, e exatamente por essa razão, esteja compreendida no pedido maior apresentado". (STJ, 2 ${ }^{\mathrm{a}}$ T., AgRg no Recurso Especial no 1.118 .704 - RJ, Relator Ministro Humberto Martins, j. 1/09/2009).

${ }^{282}$ STJ, $2^{\mathrm{a}}$ T., REsp 649957/SP, Rel. Min. Eliana Calmon, j. 23/05/2006. 


\subsection{INTERPRETANDO O PEDIDO IMEDIATO}

Como vimos no item 3.5, embora irrelevante para a delimitação do conteúdo da demanda e para sua individualização, o pedido imediato tem a função de esclarecer a escolha procedimental feita pela parte, sem a qual o juiz não saberá qual procedimento seguir ou quais requisitos formais contrastar ao ato realizado.

Aqui estamos falando da aplicabilidade das normas do processo, e não do direito material. Por este motivo, a preocupação com o contraditório é de intensidade menor, não sendo exigido do pedido imediato uma manifestação de vontade inequívoca ou tampouco correlação. Quando falamos do bem da vida (conteúdo do pedido mediato) - pelas razões já exaustivamente expostas acima - não podemos admitir a possibilidade de um pedido tácito. Todavia, o mesmo não pode ser dito quanto à escolha da técnica processual.

O pedido imediato - tanto no que tange à espécie de tutela quanto ao procedimento a ser seguido - não precisa ser nominalmente enunciado na demanda, tal como: "requer-se seja proferida tutela constitutiva mediante o procedimento comum ordinário" ou "requer-se seja emitida ordem de não fazer frente a autoridade pública (tutela condenatória) mediante o procedimento especial do mandado de segurança”.

Na verdade, em grande parte dos casos, a vontade da parte em optar por um, e não por outro procedimento, não é manifestada expressamente, mas de forma tácita, mediante vestígios deixados pela demanda, inclusive na sua forma de exteriorização.

Uma demanda que manifesta o propósito (função) específico de eliminar um ato coator proferido por autoridade pública, que se refere ao polo passivo como "autoridade coatora", que prescinde de prova oral e pericial, etc., pode ser identificada como mandado de segurança. Do mesmo modo, uma demanda pautada em documento que atesta obrigação e que não configura título executivo, visando ao pagamento de quantia ou entrega de coisa, pode ser claramente interpretado como "ação monitória", ainda que não exista pedido expresso na demanda, no sentido de que este procedimento especial seja seguido. Os exemplos são variados e, de fato, tal interpretação é comum e corriqueira em nossos foros.

Bruno Silveira de Oliveira, tratando exatamente dessa hipótese, afirma que para a identificação da espécie de ato postulatório praticado é "necessário que miremos além do conteúdo do ato, buscando em seus aspectos periféricos - como a forma e, eventualmente, o nomen juris (nessa ordem) - indícios reveladores da intenção da parte quanto ao meio adotado". O autor assim conclui que a forma do ato e o nome a ele atribuído pelo 
demandante, embora não integrem, em si mesmos, o juízo de identificação das postulações, que se limita ao conteúdo, acabam por desempenhar, nessas estritas hipóteses, "um papel supletivo". E continua: "a forma ou o nome dado à peça concorrerá para sua identificação somente quando a função a que o ato visa (informada no pedido) não bastar para lhe determinar a natureza jurídica (justamente por se poder cumpri-la por mais de um meio)". 283

Muitas vezes identificamos a escolha da parte quanto ao procedimento especialmente a partir do nomen iuris aportado como "título" da petição inicial. É importante esclarecer, todavia, que o nome é somente um entre os vestígios da vontade, serve apenas para interpretá-la, e não a esgota.

Se o conteúdo representar uma função específica, incompatível com o nome indicado, o ato deverá ser identificado pelo seu conteúdo, função, de modo que o nome somente será relevante se auxiliar na identificação deste conteúdo do pedido imediato. No conflito entre a vontade substancial e a vontade processual, aquela deverá prevalecer.

Outros aspectos processuais, como a competência, a indicação do demandado ou outras referências, que digam respeito a específicos elementos do procedimento pode deixar transparecer - ainda que mediante uma análise mais profunda - a vontade da parte quanto à técnica processual.

Podemos saber que um mandado de segurança é mandado de segurança, ainda que não exista na petição o nome ou requerimento expresso no sentido de que este procedimento especial seja seguido. A conclusão pode ser obtida quando a demanda é proposta diretamente em tribunal, dentro do prazo legal ou mesmo quando o polo passivo é designado pela autoridade coatora, e não pela pessoa jurídica. Apenas estes elementos seriam adequados e suficientes para a interpretação da vontade da parte quanto à técnica processual.

O mesmo poderia ser dito a respeito do procedimento comum sumário. Uma petição inicial acompanhada de rol de testemunhas e de quesitos periciais, dentro da hipótese legal do artigo 275 do Código de Processo Civil, permite a conclusão de que a parte optou por este procedimento, ainda que não exista nenhuma referência direta ao dispositivo legal ou ao nome "procedimento comum sumária" ou "ação sumária" ou "ação pelo rito sumário" ou outro que o valha.

${ }^{283}$ Bruno Silveira de Oliveira, Juízo de identificação de demandas e recurso no processo civil, 2011, p. 154. 
No procedimento monitório, a mesma conclusão poderia ser obtida, ao passo que demanda que vise ao pagamento de quantia ou entrega de coisa com base em documento escrito, que contenha requerimento e expedição de mandado monitório ou que não tenha nenhuma referência que permita a conclusão no sentido de que o demandante teria escolhido o procedimento comum, é suficiente para a aceitação de que a técnica escolhida foi a especial.

Desse modo, verificamos que o juiz, para identificar o pedido imediato não exige das partes a enunciação desta vontade em uma frase ou oração específica (tal como se exige quanto ao pedido mediato), bastando que seja possível identificar a pretensão a partir de dêiticos (pistas) deixados pelo demandante em sua demanda. 


\section{JUÍZO DE IDENTIFICAÇÃO DE DEMANDAS}

\subsection{POR QUE É TÃO IMPORTANTE IDENTIFICAR UMA DEMANDA?}

Como vimos no Capítulo 1 , há muitos atos processuais que se assemelham à demanda, especialmente os chamados atos postulatórios argumentativos, de modo que não é difícil conceber dificuldades na identificação de um e de outro.

Há, por isso, tendência na doutrina em chamar de "demanda" casos de pedidos implícitos ou mesmo atos típicos de defesa, tais quais as exceções substanciais. O mesmo problema se apresenta em procedimentos que admitiriam o chamado "pedido contraposto", exceções legais à congruência/inércia e também em hipóteses que a jurisprudência e a doutrina denominam "ações dúplices". Assim veremos a seguir.

O problema, no entanto, é: se não temos condições de identificar e definir, com precisão, o que é uma demanda e o que não é, podemos fomentar discussões, com consequências nefastas para o processo. Isto porque - salvo exceções expressamente previstas na lei - a demanda é o único ao qual o sistema atribui eficácia de instituir ou alterar o objeto litigioso do processo.

Existentes dúvidas sobre a "natureza" do "pedido formulado", o demandado poderia - de forma legítima à luz do sistema posto - subestimar seus efeitos, e não reagir adequadamente (com prejuízo para o contraditório), e esta omissão poderia gerar presunções processuais ilegítimas, indesejadas ou não programadas pelo sistema processual (e.g. ausência de impugnação específica, revelia, etc.).

Pensemos no seguinte exemplo: o réu alega, em contestação de "ação de cobrança", a nulidade relativa do contrato e o autor, em resposta à contestação, evidenciando que a dívida está prescrita, não se insurge contra os argumentos do réu, aceitando a inevitável improcedência do seu pedido. Nesse caso, pelo fato de ter sido pleiteada/alegada a "anulabilidade do contrato", seria possível admitir que a contestação veicularia uma "demanda constitutiva negativa" implícita e que, por consequência, a sentença, ao acolher as alegações do réu (não contestadas pelo autor), produziria coisa julgada material a respeito da invalidade do negócio jurídico? Ou seja, existiria ali uma efetiva demanda, ou se trataria de um ato de mera defesa? 
Acreditar que o ato não é uma demanda significaria crer que tal anulabilidade - a despeito de alegada - jamais poderia figurar como o conteúdo dispositivo da sentença, e que, entre outros, não produziria efeitos para além do processo (coisa julgada material). Isto, naturalmente, poderia levar o autor a não se manifestar a seu respeito, especialmente quando este se convencer de que sua pretensão, por qualquer outro motivo, não haveria de ser acolhida.

Além disso, por confiança na "técnica processual", o autor teria legítimas expectativas de que - sem uma clara demanda do réu - aquele processo não haveria de lhe trazer nenhuma outra consequência negativa, senão aquela decorrente da própria improcedência.

Diferentemente ocorreria se o ato, a despeito de informal, pudesse ser inequivocamente classificado como uma demanda (i.e. reconvenção), com pedido constitutivo negativo, hipótese em que passaria a ser legítimo exigir do autor uma resposta a seu respeito e, por consequência, aplicar todas as consequências jurídicas de uma eventual contumácia (CPC, arts. 302 e 319).

Saber, portanto, o que é uma demanda, e o que não é, em muitos casos, pode fazer toda a diferença, com inquestionáveis consequências práticas. E esta questão se mostra especialmente relevante na medida em que, conforme demonstraremos a seguir, há diferentes modos de manifestação do direito de demandar, especialmente quando refutamos o formalismo e o nomen iuris como o seu exclusivo identificador.

Nos itens seguintes, à luz do exposto acima, pretendemos desenvolver a seguinte ideia: uma demanda, para ser uma demanda, dever ser inequivocamente uma demanda, porque se não o for, prejudicará o contraditório e, em última análise, estará em desconformidade com o modelo constitucional de processo.

\subsection{OBJETO DA ANÁLISE: O JUÍZO DE IDENTIFICAÇÃO}

O desenvolvimento do processo civil, e principalmente dos estudos do formalismo voltados aos escopos do processo, produziram um resultado interessante: a forma dos atos processuais (em sentido lato) - antes colocada num pedestal, assumindo valores transcendentais, ritualísticos - foi posta em seu devido lugar. Chegou-se à conclusão de que a forma não tem valor em si mesma, e como todo o processo, é mero instrumento, 
justifica-se pela aptidão em dar ordem e segurança, atendendo a objetivos exteriores, escopos do processo, e especificamente de cada um dos atos processuais.

A primeira consequência desse pensamento foi a concepção de um formalismo flexível, ao contrário de um sistema rígido e formalista, com a valorização da regra da liberdade (CPC, art. 154) e da instrumentalidade das formas (CPC, art. 249) e do dever de saneamento das irregularidades processuais (CPC, art. 284 e $515 \S 4^{\circ}$ ), sempre em busca da efetividade do processo. ${ }^{284}$

A segunda consequência foi a constatação de que, pela sua variabilidade e importância, a forma não pode ser o único critério para a identificação de um ato processual, i.e. saber se uma demanda é uma demanda, se um recurso é um recurso, se uma sentença é uma sentença, se um despacho é um despacho, e não outro ato similar.

Esta conclusão provocou mudanças no modo em que enxergamos o processo civil, transformando a aplicação da técnica processual, com muitas repercussões já aceitas pela jurisprudência.

A título de exemplo, podemos mencionar que é assente a ideia de que a "exceção de incompetência", ainda que apresentada em total descompasso com o modelo formal (i.e. no corpo da própria contestação), não impede a caracterização do ato como tal, permitindo a posterior análise de sua admissibilidade e mérito. Do mesmo modo, a jurisprudência é tranquila ao afirmar que uma decisão interlocutória, ainda que produzida sob a forma (mais simples) de um despacho, não altera sua natureza, admitindo impugnação pela via do agravo. Entre outros casos que trataremos neste trabalho (cf. item 5.4).

Afastada a forma como critério, portanto, tampouco o nome atribuído à peça processual (nomem juris) pode servir a este mister, na medida em que a nomeação das coisas não tem, nem poderia ter, aptidão de alterar o que elas são; e.g uma apelação chamada de agravo não deixa de ser apelação, um agravo regimental chamado de pedido de reconsideração não deixa de ser recurso, uma decisão interlocutória chamada de despacho não deixar de ser o que é. A dificuldade está, exatamente, em saber o que é o que.

Tais circunstâncias - valendo para todos os atos processuais - valem também para as demandas, e esta consideração é relevante na medida em que pode ser extremamente difícil diferenciar uma demanda de um mero requerimento, ou mesmo diferenciá-la de uma peça de defesa, tal qual a contestação, onde também há pedido de tutela jurisdicional. E

\footnotetext{
${ }^{284}$ Por todos, cf. Bedaque, Efetividade do processo e técnica processual, p. 94 e ss.
} 
inexiste forma específica ou um nomen iuris que, uma vez aportado, possa permitir a conclusão inexorável de que o ato analisado cuida, efetivamente, de uma demanda. Precisamos, portanto, de critérios mais seguros para a identificação do ato processual.

Existindo demandas iniciais e ulteriores, demandas do réu, do autor e de terceiros, demandas reconvencionais, pedidos contrapostos, pedidos dúplices, pedidos implícitos, demandas do executado, etc., e não existindo uma forma ou um critério nominal que tenha aptidão para identificá-la, resta-nos a questão: como fazê-lo? ${ }^{285}$

À luz das premissas citadas, cogita-se ainda a possibilidade de um ato de natureza meramente defensiva (exceção substancial) alterar o objeto litigioso do processo. Seria isso possível? Cogita-se também a possibilidade de formulação de diferentes demandas no processo civil, especialmente daquelas de natureza reconvencional, sem uma rotulação específica ou uma forma específica para o ato. Seria possível? E, se a resposta for positiva, teríamos critérios claros na técnica processual para identificar tais atos e atribuir-lhes a adequada eficácia?

Estas questões têm relevância na delimitação do objeto litigioso do processo e deverão ser respondidas mediante análise do chamado juízo de identificação dos atos postulatórios, pelo qual pretendemos isolar um conteúdo específico capaz de permitir independentemente de forma ou rótulo - a identificação segura de um ato como demanda, para que depois disso possam ser analisados (i) seus requisitos de admissibilidade; e (ii) mérito.

Nos capítulos anteriores, esforçamo-nos em tentar distinguir a forma do conteúdo da demanda, de modo a identificá-lo a partir dos seus elementos. Neste capítulo, também levaremos em conta o conteúdo da demanda, no entanto, não com o propósito de estabelecer relações entre demandas, individualizando o objeto litigioso do processo. Nosso propósito será distinto: o de identificar uma demanda, diferenciando-a doutros atos processuais. $^{286}$

${ }^{285} \mathrm{O}$ problema extrapola inclusive os limites da fase cognitiva. O direito processual não apresenta, hoje, critérios claros para determinar se atos, especialmente no âmbito da execução forçada, configuram efetiva demanda, ou se tratam de mero requerimento, e.g. (i) impugnação ao cumprimento de sentença; (ii) liquidação de sentença; (iii) exceção de pré-executividade; (iv) embargos à execução; (v) habilitação de sucessores; (vi) habilitação de crédito; (vii) incidente de falsidade documental; (viii) pedido de declaração de fraude à execução; (ix) pedido de declaração de desconsideração de personalidade jurídica; etc.

${ }^{286}$ Esta distinção terá relevância - assim como a individualização da demanda - para que seja possível estabelecer relações entre demanda e tutela jurisdicional, que constituem o objeto do presente trabalho.

Para saber até qual ponto pode ir o juiz ao conceder a tutela não basta que saibamos identificar o objeto litigioso do processo, à luz dos elementos da demanda, precisamos, antes disso, identificar quais atos processuais têm aptidão para instituir e modificar este mesmo objeto litigioso (demanda) e quais não têm (outros atos postulatórios). 


\subsection{NOME E FORMA SÃO SUFICIENTES PARA IDENTIFICAR UMA DEMANDA?}

Um ato postulatório deve preencher, segundo posição dominante na doutrina, duas ordens de requisitos formais; (i) requisitos de admissibilidade, que dão direito ao procedimento (à análise do mérito); e (ii) requisitos de mérito, que dão direito ao conteúdo da pretensão formulada (procedência dos fundamentos).

Antes, no entanto, de avaliarmos se um ato postulatório é admissível (juízo de admissibilidade), pois preenche todos os seus requisitos formais ou mesmo se é procedente, existindo no mérito os requisitos necessários para o acolhimento do pedido (juízo de mérito), existe outro juízo logicamente anterior aos demais, que diz respeito à identificação.

De modo que possamos, em momento posterior, afirmar se estão preenchidos os requisitos de admissibilidade de um ato, é necessário antes investigarmos quais requisitos legais de admissibilidade se aplicam (i.e. quais normas jurídicas devem regulá-lo), e isso somente é possível mediante prévio juízo quanto à identificação. Para tanto, formulamos questões como estas: Trata-se de um recurso? Se positivo, qual espécie de recurso? Tratase de demanda? Se positivo, qual espécie de demanda?

O desenvolvimento desta categoria coube a Bruno Silveira de Oliveira, o qual afirma que o juízo de identificação é tomado como óbvio e normalmente passa despercebido. Todavia, é de inegável relevância, pois resultam dele consequências importantes, a começar pela definição do órgão competente para os juízos de admissibilidade e de mérito do ato praticado, passando também pela determinação das normas que regem esses juízos e o procedimento. ${ }^{287}$

Ora, o que diferencia um recurso de outro ato processual, especialmente quando este dentro de um prazo e mediante manifestação escrita pede a revisão ou reconsideração de pronunciamento judicial? Basta chamar o ato de recurso para que ele passe a o ser? Acreditamos que não. E mais, o que configuraria uma demanda? Basta chamá-la como tal? A resposta aqui também é negativa, tampouco o nomen iuris "ação", acompanhado de qualquer outra palavra (ação ordinária, ação declaratória, etc.), utilizado nas mais diversas formas é elemento necessário ou suficiente para fazer de um ato qualquer uma demanda. ${ }^{288}$

\footnotetext{
${ }^{287}$ Cf. Bruno Silveira de Oliveira, O juízo de identificação de demandas, 2011, p. 64 e ss.

288 A respeito da relevância do nomen juris para a identificação dos atos postulatórios, após ressaltar a constante presença, por uma questão de hábito, de um nomen juris atribuído a cada ato postulatório, e.g. ação
} 
Palavras não se confundem com as coisas que são usadas para nomear e não é possível crer que o ordenamento jurídico teria dados poderes suficientes aos sujeitos processuais para que, com a simples nomeação do ato, "verdadeiro passe de mágica", determinassem sua categoria jurídica.

Um ato processual não é um recurso simplesmente porque denominado como tal, do mesmo modo, simplesmente porque chamado de demanda ou mesmo de ação, o ato da parte não passa a assumir automaticamente a "natureza" de demanda. Podemos dizer que e.g. não são embargos de declaração o recurso que pede a reforma de decisão monocrática de tribunal com exato conteúdo de agravo regimental, simplesmente pelo fato de ser nomeado pelo recorrente como embargos de declaração. Da mesma forma, não é mero pedido de reconsideração o pedido de reforma dessa mesma decisão, quando assim denominado. Embora sem dizê-lo, este já é o entendimento de nossas cortes. ${ }^{289}$

Especialmente quanto aos atos do juiz, a jurisprudência é prolífica ao consignar que a nomeação equivocada do ato, que atribui à decisão interlocutória o nome de despacho ${ }^{290}$ ou mesmo que atribui à sentença o nome de decisão interlocutória ${ }^{291}$ não altera

condenatória, ação declaratória, ação de mandado de segurança, ação cominatória, ação possessória, etc., Bruno Silveira de Oliveira sustenta não se estar este elemento contido na noção de forma processual. "Bem poderíamos, commoditatis causa, embrenhar a noção de nomen juris sob aquela, há pouco fixada, de 'forma em sentido estrito' (modo de ser) do ato. Afinal, ele - o nome dado à peça - não deixa de ser, como foi dito, um dos meios pelos quais a parte visa a transmitir o sentido de sua pretensão. Lá está o nomen juris, sempre, apenas e precisamente para isso. Não obstante, impõe-se apartá-lo da noção de "forma" por uma razão muito simples: nosso sistema processual trata o nome e a forma das postulações de maneiras distintas; confere a esta importância que não dá àquele, na medida em que a ausência de algum caractere formal implica normalmente a inadmissibilidade do ato praticado (ou, antes, a necessidade de se adequar sua formatação), ao passo que em nenhum momento se exige, sob pena alguma, a imputação de um nomen à peça produzida, tampouco a retificação de erros em sua denominação. Logo, a rigor, o nome do ato é uma coisa, sua forma é outra, seu conteúdo outra ainda". (O juízo de identificação de demandas, 2011, pp. 61-62).

289 Para decidir deste modo, os tribunais recorrentemente invocam o chamado "princípio" da fungibilidade recursal. Cf. STJ, $1^{\mathrm{a}}$ T., RCREAG 789.738/RJ, Rel. Ministro Luiz Fux, j. 05.12.2006. Em outro trabalho, este autor teve a oportunidade de criticar tal justificativa. "Nesses casos, como é evidente, não há qualquer indício de dúvida objetiva. Na primeira hipótese, inexiste qualquer incerteza quanto às hipóteses de cabimento dos recursos, já que os embargos de declaração visam a sanar vícios de omissão, contradição ou obscuridade (CPC, art. 535) e o agravo regimental, por sua vez, tem natureza tipicamente infringente, visando à reforma ou à anulação da decisão impugnada (CPC, art. 520). No segundo caso, por sua vez, a imprecisão é ainda maior, pois, além de $(i)$ não haver qualquer incerteza quanto à técnica processual (não há dúvida objetiva entre as "hipóteses de cabimento" de pedido de reconsideração e agravo regimental); (ii) sequer tratamos de dois tipos de recurso, sendo inviável falar em fungibilidade recursal. (Incerteza $e$ processo, 2013, p. 77)

${ }^{290}$ Cf. STJ, $1^{\text {a }}$ T., REsp 469.924/RJ, Rel. Ministro Luiz Fux, DJ 16/06/2003, p. 266; e STJ, $4^{\text {a }}$ T., REsp 19.031/PR, Rel. Ministro Sálvio de Figueiredo Teixeira, DJ 24/02/1997, p. 3335.

${ }^{291}$ Nesse sentido, decidiu o STJ que “(...) Pondo o Juízo fim ao processo por sentença, denominada, por equívoco, mas expressamente, "decisão interlocutória", nas circunstâncias do caso, não constitui erro grosseiro, ofensivo ao princípio da unirrecorribilidade recursal, a interposição tempestiva de Agravo de Instrumento e de Apelação, julgando-se esta, pelo Tribunal de origem, após o trânsito em julgado de Acórdão que não conheceu daquele". (STJ, 33 T., REsp 1215073/DF, Rel. Ministro Sidnei Beneti, DJe 27/03/2012) 
a natureza do pronunciamento judicial, que continuar ser o que é independentemente de seu nomen iuris. ${ }^{292}$

Ora, os nomes não mudam a substância das coisas, são meros rótulos e têm relevância pontual no sistema jurídico, de modo que mesmo que trocados ou erradamente utilizados pelo juiz ou pelas partes as coisas não deixam de ser o que são. Não é critério que - de um modo geral - possa desempenhar papel relevante na identificação dos atos processuais: "o nome que se dê ao ato praticado, em regra, não lhe determina a identidade, sequer lhe arranha a essência". 293

Afastado o nome, também a forma não é critério confiável para a identificação de um ato processual. Isto se dá, inicialmente, pois há atos distintos que assumem exatamente a mesma forma legal, i.e. são exteriorizados mediante os mesmos requisitos formais, assim como há atos processuais, de mesma categoria, que assumem formas distintas (podem se submeter a requisitos formais distintos).

A título de exemplo, podemos citar os recursos especiais e recursos extraordinários que, a despeito de tratarem de espécies recursais distintas, se mostram, formalmente (forma em sentido estrito), idênticos, submetendo-se aos mesmos requisitos de tempo (15 dias), modo (regularidade formal) e lugar (tribunal onde proferido o acórdão recorrido). A única distinção entre estas duas categorias - além do nome, que já mostramos ser irrelevante - está em seu conteúdo, i.e. sua função. Os primeiros exercem, dentre outras, a função de reformar ou anular acórdãos em desconformidade com a lei federal

${ }^{292}$ Esta parece ser a inclinação da jurisprudência alemã e italiana, Paolo Divitiis, tratando exatamente desta questão, à parte não se pode exigir conhecimento jurídico superior ao do juiz que proferiu a sentença, motivo pelo qual não é lícito declarar a invalidade de seu ato, quando seu equívoco se justifica por um equívoco anterior do juiz da causa. Cf. Paolo Divitiis, "Sulla teoria del meistbegüstigung...", Rivista di Diritto Processuale 2, 1993, p. 412; e Tarzia, "Le instruzione del giudice...", Rivista di Diritto Processuale 4, 1981, pp. 656-657.

${ }^{293}$ Assim recorremos à lição de Bruno Silveira de Oliveira: "De fato, existe um fosso entre as palavras e as coisas, distância que apenas a Idade Moderna - em sua incessante busca por cientificidade - logrou perceber e demarcar com clareza. O pensamento primitivo, fundado que era em mitos e em preconceitos perpetuados pela tradição, não conhecia aquele fosso. Ao invés, acreditava em que as palavras, intrinsecamente, portassem os valores e as características dos entes que representavam (confundindo-se, assim, com os próprios). Nada mais rudimentar (a rosa, por exemplo, jamais deixará de recender seu perfume se - ao invés de "rosa" - passarmos a chamá-la de "cravo" ou de "jasmim"). Essa constatação, singela e óbvia, é todavia uma conquista recente da inteligência humana; revela a maneira como concebemos moderna e contemporaneamente apenas - as relações entre os signos e os entes por eles denotados. (...) Em pleno século XXI, no entanto, não mais se admitem confusões do tipo, de sabor indisfarçavelmente medieval. Seu despropósito fica muito claro a partir de alguns exemplos, de correção por si própria evidente. Vejamos então, ilustrativamente, que os nomes chuva; rain; Regen; pioggia e pluie são - nessa ordem - as palavras portuguesa, inglesa, alemã, italiana e francesa para a designação de um mesmo acontecimento, conhecido de todos, único e igual em todo o mundo: a chuva. É óbvio que ela não se torna outra coisa na Inglaterra apenas por se chamar rain naquelas plagas. E assim como pode uma só coisa receber vários nomes (acabamos de ver), pode também uma única palavra representar várias coisas, que não por isso haverão de ser confundidas entre si (exemplo: manga [palavra] difere de manga [fruta], e ambas se distinguem de manga [da camisa])". (O juízo de identificação de demandas, 2011, pp. 66-67). 
(CF, art. 105, III). Os segundos, por sua vez, visam, dentre outras funções, a reformar ou anular acórdãos ou sentenças que ofendam o texto constitucional (CF, art. 102, III).

Há, ainda, quanto a esta questão, a possibilidade de os atos processuais, de uma forma geral, serem registrados por meio físico escrito ou por meio eletrônico, conforme determinam as leis 11.280 e 11.419 de 2006. Diferentes atos - de mesma "natureza" podem ser manifestados de modo distinto. Com base nesse fundamento, uma demanda pode ser ajuizada de forma eletrônica - assumindo registro digital - ou pode ser ajuizada de forma física, tradicional, em papel, sem que deixe de manter exatamente a sua mesma função jurídica.

Não fosse isso suficiente, a incidência do princípio da liberdade das formas (CPC, art. 154) e da regra da instrumentalidade das formas (CPC, art. $249, \S \S 1^{\circ}$ e $2^{\circ}$ ), que possibilita a realização de atos processuais em desconformidade com o modelo formal abstrato, desde que o ato atinja seus objetivos, ressalta a circunstância de que, pela sua variabilidade, a forma não é critério seguro para a identificação dos atos processuais.

A exteriorização do ato, seja porque, sendo idêntica, tem a aptidão de veicular atos processuais distintos, ou mesmo porque, sendo distinta, tem aptidão para veicular atos de mesma natureza (conteúdo), não cuida de critério confiável para os nossos propósitos: não configura ou sequer desfigura categoria do ato processual. ${ }^{294}$ Necessário, portanto, buscar outra referência, o que faremos nos itens a seguir.

\footnotetext{
${ }^{294}$ Assim, Bruno Silveira de Oliveira: “é que, por vezes, a lei: (i) estabelece a mesma forma para a prática de espécies distintas (ou seja: postulações de conteúdos e de funções distintas podem revestir-se de uma mesma forma); por outras (ii) prescreve formas alternativas para a prática de um mesmo ato (ou seja: uma única espécie postulatória pode assumir mais de uma das formas previstas em lei). Temos exemplo da primeira situação na forma dos recursos especial e extraordinário. Dos pontos de vista da tempestividade e da regularidade formal, é simplesmente impossível diferenciar esses recursos. A distinção entre eles, sabidamente, pauta-se nas hipóteses de cabimento de cada um: ao passo que o recurso especial se presta ao controle da aplicação da lei federal, o extraordinário visa à correta aplicação das normas constitucionais sobre questões de repercussão geral. Desses cabimentos - de sentidos e funções diversas - decorrem simétricas diferenças quanto às fundamentações a que um e outro daqueles recursos estão vinculados (lei federal, no especial; questões constitucionais de repercussão geral, no extraordinário). Pelo que se pode afirmar, $a$ fortiori, que é o conteúdo de cada um (suas diferentes fundamentações) aquilo que os distingue". (O juízo de identificação de demandas..., 2011, p. 107).
} 


\subsection{NÃO É QUALQUER SORTE DE POSTULAÇÃO QUE IDENTIFICA UMA DEMANDA}

Esclarecido que o nome atribuído ao ato postulatório ${ }^{295}$ e que a forma de exteriorização do ato, por si só, não são aptos a configurar um ato postulatório como demanda, resta questionar, como fazê-lo?

Vimos no Capítulo 1 que todo ato postulatório representa uma locução linguística que exerce uma determinada função, isto é, o ato tem uma razão de ser, visa a um objetivo que lhe é exterior e, portanto, cuida de instrumento, meio para um objetivo final. ${ }^{296} \mathrm{E}$ é exatamente neste objetivo que reside chave para a identificação de um ato como demanda.

A demanda se configura como tal a partir do seu conteúdo (manifestação de vontade) e da função que exerce no sistema processual. Dentro da categoria dos atos postulatórios, difere-se dos demais atos, tais quais os recursos, requerimentos de provas, defesas e demais alegações das partes, pelos efeitos que tem aptidão para produzir. Especialmente, pela eficácia criadora do dever do Estado-Jurisdição em apreciar um pedido de tutela jurisdicional (mérito), sem o qual não teria condições de apreciar.

Os atos postulatórios em geral levam à necessidade de uma resposta, de qualquer natureza, por força da garantia do contraditório, da ampla defesa ou do acesso à justiça. Os atos postulatórios argumentativos, por sua vez, por apresentarem maior grau de complexidade, veiculam uma solicitação de pronunciamento que exija do juiz atividade intelectiva relevante, e têm fundamento nos mesmos princípios citados (alteram o objeto cognitivo do processo). As demandas, diferentemente, não se limitam a solicitar uma resposta jurisdicional, ou mesmo uma resposta que pressuponha a solução de situações jurídicas complexas, mas manifestam a vontade da parte - de forma inequívoca - pela instauração da atividade jurisdicional (demandas iniciais) ou ampliação posterior de seus limites (demanda ulteriores).

Em outras palavras, de modo geral, somente a demanda exerce a função no sistema de instaurar ou de alterar o objeto litigioso do processo (mérito). Não apenas amplia os elementos que serão integrantes da cognição do juiz (objeto cognitivo do processo), ou mesmo traz alegações ou elementos probatórios, como também amplia a

\footnotetext{
${ }^{295}$ Fala-se, aqui, especificamente nos atos postulatórios argumentativos, pois os meros requerimentos, sem conteúdo de argumentação, se distinguem mais claramente da demanda, na medida em que dispensam a apresentação de qualquer causa ou fundamento racional. Seu conteúdo é, portanto, muito distinto da demanda, a justificar a dispensa da análise específica da questão.

${ }^{296}$ Cf. Dinamarco, A Instrumentalidade..., $12^{\mathrm{a}}$ ed., p. 329.
} 
extensão do objeto da tutela jurisdicional, inserindo no processo novo petitum ou nova causa pretendi ou ambos. ${ }^{297}$

Quando cuidamos de um recurso, pressupomos sempre a existência prévia de uma demanda e de uma decisão judicial. O recurso, por sua vez, tem a função específica de revisar (juízo rescindente e/ou rescisório) decisão judicial já proferida, sem aptidão para inserir novos pedidos de tutela jurisdicional ou mesmo de alterar os elementos que identificam o processo. O recurso não retira o Estado da inércia, mas simplesmente prolonga a litispendência.

Do mesmo modo, um ato meramente defensivo, tal qual a contestação, não retira o estado de inércia. A despeito de conter pedido de tutela jurisdicional, este pedido - ao contrário do que ocorre em relação à demanda - não é essencial à tutela pleiteada. A improcedência do pedido do autor (tutela para o réu) pode ser obtida mesmo sem contestação, no entanto, a procedência do pedido do autor somente é obtida porque houve, anteriormente, uma demanda.

Com efeito, podemos concluir que é exatamente pelo seu conteúdo argumentativo próprio e pela sua função de instaurar/ampliar o objeto da atividade jurisdicional, retirar o Estado da posição de inércia e obrigá-lo a fornecer resposta a respeito da aplicação do direito ao caso concreto (comando sentencial), que se identifica um ato processual como demanda. ${ }^{298}$

\footnotetext{
${ }^{297}$ Não mencionamos aqui a mera alteração da parte, pois, quando esta ocorre por força de uma demanda, deve-se considerar que, antes de a demanda implicar na alteração das partes, esta configura necessariamente um novo pedido. E.g. na inclusão de litisconsorte passivo necessário o autor formula nova demanda, pois o pedido original se identifica pelas partes por ele vinculadas. Ingressando nova parte, temos novo pedido necessariamente, ainda que tratemos do mesmo bem da vida e do mesmo substrato fático.

298 Normalmente, a demanda se caracteriza pela entrega de um bem da vida e, estes, por definição, são regulados pelo direito material. Ocorre que, no caso da ação rescisória (CPC, art. 485), temos um pedido de tutela jurisdicional que corresponde a um bem da vida e que, especialmente no juízo rescindente, tem como fundamento uma norma de direito processual. Trata-se de única exceção, da qual decorre a tipicidade da ação rescisória. Assim é a lição de Flávio Luiz Yarshell: “...tem-se como certo que as garantias constitucionais de ação e da inafastabilidade do controle jurisdicional devem ser interpretadas de sorte a delas se extrair formas de tutela ou tipos de provimento aptos a solucionar, efetiva e adequadamente, todas as situações de violação (ou ameaça de violação) de direitos e interesses protegidos no direito substancial. (...) Contudo, há casos em que a tutela - entendida como o resultado proporcionável pelo processo - é prévia e taxativamente limitada pela lei processual, que deliberadamente impõe limites à produção de certos efeitos. É o caso do provimento apto à desconstituição da sentença de mérito transitada em julgado. Daí falar-se na ação rescisória como ação típica: vista sob o ângulo do resultado decorrente da procedência de uma ação rescisória, a tutela aí prestada pode também reputar-se típica, eis que a situação de desvinculação da coisa julgada (subjetiva e objetivamente) somente se obtém com base naquele provimento taxativamente autorizado pela lei" (Tutela jurisdicional, $2^{\mathrm{a}}$ ed., pp. 147-149).
} 


\subsection{DIFERENTES NÍVEIS DE IDENTIFICAÇÃO}

No chamado "juízo de identificação de demandas", trataremos de identificar o que deve existir - de específico - em um ato processual para que possa ser chamado de demanda, é dizer, qual é o conteúdo que a identifica. Entendemos que esta análise é inevitável, muito embora na grande maioria das vezes a identificação dos atos processuais ocorra de modo quase que imperceptível, sem grandes ou nenhum problema. ${ }^{299}$

Por qual motivo isso ocorre?

Normalmente, os enunciados prescritivos (textos legais) não contêm a descrição minuciosa de um ato específico e, por consequência, a previsão de determinadas exigências jurídicas que a ele se aplicariam. Isto $e . g$. ocorreria se a lei optasse por prever textualmente enunciado como este: Caso seja apresentado ato da parte que tenha por objetivo específico obter a reforma ou anulação de pronunciamento judicial com conteúdo cognitivo relevante e capaz de gerar prejuízo que, por sua vez, não tenha por objetivo qualquer das situações dos artigos 267 e 269 do Código de Processo Civil, a parte deverá apresentar este recurso no prazo de 10 (dez) dias, a contar da intimação do ato decisório, mediante petição escrita apresentada diretamente ao Tribunal, que impugne especificamente os fundamentos da decisão e peça sua reforma ou anulação, devendo comprovar no ato da interposição o recolhimento do preparo e apresentar, juntamente com a petição recursal devidamente fundamentada, cópia da certidão de intimação, das procurações outorgadas aos advogados das partes, da decisão recorrida e de outros documentos pertinentes à elucidação do caso.

Diferentemente, a lei (texto legal) se vale de atalhos (categorias jurídicas) para resumir seus enunciados, e - querendo dizer exatamente a mesma coisa - prescreve algo bem mais resumido: das decisões interlocutórias cabe agravo de instrumento (CPC, arts. 524 e 525$)$.

Desse modo, ao contrário de simplesmente contrastar o texto legal com o ato concreto, para saber quais requisitos se deve cumprir, o jurisdicionado deve antes descobrir

\footnotetext{
${ }^{299}$ O juízo de identificação dos atos processuais, mais especificamente aquele que permite a identificação dos atos postulatórios, pressupõe a qualificação de determinados atos (realizados em concreto) a categorias jurídicas abstratas, de modo, que, a partir dessa averiguação, possa ser realizada a subsunção do fato a uma norma e avaliadas as consequências jurídicas daí decorrentes. Os atos, em concreto, são identificados como pertencentes a uma determinada categoria jurídica tão somente para permitir sejam determinadas as normas jurídicas aplicáveis. Tal processo lógico tem relação com a forma de produção do próprio direito positivo (confecção dos textos legais).
} 
o conteúdo jurídico da expressão "agravo de instrumento", é dizer, deve saber o que essa categoria jurídica significa para, depois, exercer juízo de identificação sobre o ato, vendo se aquele ato concreto, antes de qualquer coisa, é ou não é, um agravo de instrumento e posteriormente avaliar os requisitos de admissibilidade.

Por este motivo, no âmbito dos recursos, não basta identificar um ato como tal (recurso), diferenciando-o de mero pedido de reconsideração, de ação rescisória ou de outro sucedâneo recursal, é necessário inseri-lo adicionalmente em uma das subcategorias recursais, é dizer, tipo recursal. A partir daí teremos diferentes hipóteses de cabimento, diferentes prazos, diferentes requisitos internos de admissibilidade e diferentes procedimentos recursais a serem seguidos (formalismo distinto).

O mesmo ocorre em relação às demandas. Não basta diferenciar uma demanda de um ato de mera defesa ou de um requerimento simples, formulado no curso do processo. Isto se dá, pois há diferentes espécies de demandas, subcategorias que se submetem a requisitos distintos.

Neste ponto, porém, as demandas e os recursos se diferenciam. Exatamente por se tratarem de meios processuais típicos, basta identificarmos um ato como recurso $\left(1^{\circ}\right.$ nível de identificação) de tal espécie ( $2^{\circ}$ nível de identificação), de modo que possamos afirmar quais normas de competência, admissibilidade e procedimento deverão ser aplicáveis ao ato, seja do ponto de vista meramente formal, seja do ponto de vista dos efeitos a serem produzidos, pelo recurso e pelo seu julgamento.

Se o ato tem como objetivo obter a reforma ou anulação de uma sentença, o ato deve ser uma apelação e, o sendo, terá determinados requisitos de admissibilidade e seguirá determinado procedimento. Por sua vez, se tiver o objetivo de reforma ou anulação de decisão interlocutória será agravo, com requisitos de admissibilidade, competência e procedimentos distintos e assim por diante.

As demandas, no entanto, admitem diferentes procedimentos e diferentes regras de competência e admissibilidade, e para que possam ser adequadamente identificadas (tipo de demanda) dependem de três níveis de classificação. Como veremos, em $1^{\circ}$ nível, o ato será classificado como demanda ou não (com base apenas em seu conteúdo substancial); em $2^{\circ}$ nível, a demanda será distinguida em inicial ou ulterior (com base no critério topológico); e, em $3^{\circ}$ nível, serão determinadas as escolhas procedimentais feitas pelo demandante (a partir do pedido imediato). Assim o veremos. 


\subsection{DEMANDA INICIAL E DEMANDA ULTERIOR}

Existe uma relação de dependência entre demanda e processo. O processo, por força do princípio da inércia e da vedação da instauração ex officio, somente nasce após proposta uma demanda: fundamental para o início do procedimento e para o nascimento da relação jurídica processual. ${ }^{300}$

Quando isto de fato ocorre, i.e., quando uma demanda tem por função ou objetivo instaurar um processo e dar início a um determinado método de trabalho, falamos de uma demanda inicial.

A função do ato, portanto, que classifica a demanda como tal, recebe um acréscimo, para que a demanda se insira na subcategoria demanda inicial; não basta que se trate de um ato da parte de natureza postulatória e argumentativa que tenha por objetivo romper a inércia e formular novo pedido, é necessário que, além disso, este ato tenha uma função de instituir o objeto de um processo, dando-lhe início.

E esta função, é necessário esclarecer, não é exercida apenas pela petição inicial, mas por ela e qualquer outro ato que venha a alterá-la ou retificá-la, nas hipóteses admitidas de emenda à petição inicial (CPC, art. 284 e 327). Isto ocorre, pois o ato de emenda deverá se submeter aos mesmos requisitos de forma que a própria petição inicial, aderindo-se a ela como se fosse um ato somente. Depois de emendada, inicial e emenda são considerados pelo processo civil como um ato só. ${ }^{301}$

As demandas ulteriores, por sua vez, são aquelas que detêm a função específica de alterar o objeto de um processo já em curso. A possibilidade de formulação de demandas ulteriores estaria inicialmente franqueada ao autor, na medida em que este tem autorização para propor ação declaratória incidental, com o objetivo de ampliar o objeto litigioso do processo, a partir da solicitação de um provimento de mérito de natureza

\footnotetext{
${ }^{300}$ Devem ser aqui excetuadas as hipóteses tratadas pela doutrina de demandas ex officio, como ocorre na hipótese do inventário. CPC, art. 989: “O juiz determinará, de ofício, que se inicie o inventário, se nenhuma das pessoas mencionadas nos artigos antecedentes o requerer no prazo legal”.

301 Nesse sentido, leciona Dinamarco: “Antes que o réu seja citado e portanto sem necessidade de qualquer anuência ou autorização, pode ser acostado ao pedido originário um outro - com o que se estabelecerá um cúmulo ulterior de pedidos (art. 294). Depois da citação será ainda possível aditar, quer para cumular um pedido antes ausente ou algum novo fundamento ao pedido inicial, quer para substituir pedidos ou fundamentos (cúmulo ulterior de pedidos ou de fundamentos) - mas, agora, na dependência da concordância do demandado (art. 264). Depois de saneado o processo, diz o Código que seria absolutamente inadmissível aditar pedidos ou fundamentos (art. 264, par., c/c art. 331), mas os tribunais flexibilizam essa norma para estabelecer que, havendo concordância do réu e nenhum prejuízo sendo causado à regularidade do processo ou da instrução, poderá em tese sobrevir algum aditamento, com possível formação de um cúmulo ulterior". (Instituições de direito processual civil, vol. II, 2005, item 478).
} 
declaratória que tenha como objetivo sanar crise de certeza estabelecida quanto a uma questão prejudicial de mérito.

Ao réu, no entanto, as possibilidades são muito mais amplas. Quando formula demandas não apenas se defende, contra-ataca. Pode formular demanda ulterior, assim como o autor, de natureza declaratória incidental ou, ainda, demandas ulteriores como a reconvenção ou "pedido contraposto" ou denunciação da lide, iniciativas estas que “alargam o campo de julgamento e então o juiz deverá julgar não só a demanda inicial do autor, mas também a proposta pelo réu (CPC, art. 128)". 302

Na reconvenção, o réu apresenta em face do autor demanda afim ao processo em curso ou relacionada aos próprios fundamentos da defesa (CPC, art. 315). Na ação declaratória incidental, a finalidade é a mesma, mas o pedido limitado à declaração da existência, inexistência ou modo-de-ser de determinada relação jurídica que possa trazer repercussões para o objeto litigioso do processo e curso (questões prejudiciais - CPC, arts. 5o e 325). ${ }^{303}$ Disso trataremos pormenorizadamente mais adiante.

Ademais, o réu está autorizado a formular demanda em face de terceiro, de modo que este venha, eventualmente, a responder pelas perdas fixadas no processo originário em seu desfavor, na forma de denunciação da lide (CPC, arts. 70, 75, 76). ${ }^{304}$

O réu também está autorizado a chamar ao processo "sujeito a quem atribui solidariedade na obrigação cobrada pelo autor", fazendo-o seu litisconsorte e pedindo que, em caso de procedência da demanda inicial, seja a este imposta condenação solidária (CPC, arts. 77, 80). ${ }^{305}$

São estas as possibilidades numerus clausus de demanda ulterior do réu, admissíveis no procedimento comum ordinário e excepcionalmente admitidas nos demais. Conforme leciona Dinamarco, "afora essas hipóteses de manifesta legitimidade e regidas por lei, não é permitido ao réu carrear outras demandas ao processo ou promover o alargamento da que o autor propôs". 306

Por fim, demandas ulteriores podem ser propostas por terceiros, sujeitos que originariamente não figuravam como parte, mas que, ao fazê-lo (demandarem), passam a o ser, pleiteando tutela jurisdicional em seu favor. A forma mais característica é a oposição, pela qual o terceiro comparece afirmando ser titular do direito disputado entre as partes

\footnotetext{
302 Dinamarco, Instituições de direito processual civil, vol. II, 2005, item 478.

303 A respeito das semelhanças entre ação declaratória incidental e reconvenção, cf. Clito Fornaciari Júnior, Da reconvenção no direito processual civil brasileiro, pp. 45-48.

${ }^{304} \mathrm{Cf}$. Gonçalves, Intervenção de terceiros, 1996, p. 214 e ss.

${ }^{305}$ Cf. Gonçalves, Intervenção de terceiros, 1996, p. 271 e ss.

${ }^{306}$ Dinamarco, Instituições de direito processual civil, vol. II, 2005, item 478.
} 
originárias, pleiteando o bem da vida para si (CPC, arts. 56 ss. - infra, n. 596). A lei (9289/96 e 12016/2009) admite ainda a intervenção litisconsorcial voluntária, pela qual o terceiro comparece para pedir sua inclusão no polo ativo do processo, deduzindo "seu próprio pedido em face do réu". 307

O critério, com efeito, que distingue as demandas iniciais das demandas ulteriores é objetivo, e se relaciona com o momento de exercício do direito de ação: caso este implique em instauração de um processo, falamos de demanda inicial, caso implique em ampliação ou modificação do objeto litigioso de processo já pendente, falamos em demandas ulteriores.

\subsection{ESPÉCIES DE DEMANDAS INICIAIS}

Afirmamos acima que o juízo de identificação de demandas tem uma necessidade prática, que é permitir a identificação dos requisitos de competência, admissibilidade e procedimento do ato processual, bem como dos efeitos que este ato deverá produzir no processo.

Desse modo, resta claro que a simples identificação de um ato como demanda, ou mesmo como demanda inicial ou ulterior, é insuficiente. Não permite sejam obtidas todas as respostas necessárias. Para tanto, precisamos afirmar de qual subespécie de demanda inicial ou de demanda ulterior estamos tratando, de modo que possamos fazer a adequada subsunção do ato (em concreto) ao modelo processual (norma jurídica) aplicável.

\footnotetext{
${ }^{307}$ Dinamarco refere-se ainda à assistência. No entanto, admitindo-se que esta (especialmente no caso da assistência simples) não ampliaria o objeto litigioso do processo, não pode se tratar de demanda, tal como a definimos. "A assistência, que também é modalidade de intervenção voluntária de terceiro, não alarga o pedido nem seus fundamentos. O terceiro faz-se assistente de uma das partes com a finalidade exclusiva de ajudá-la na defesa de seus interesses e nos limites do litígio posto em juízo (arts. 50 ss.). Nada pede para si (infra, n. 597)". O autor fala ainda na possibilidade de o próprio juiz alargar o objeto litigioso do processo, ao chamar litisconsorte passivo necessário. "O juiz alarga de-ofício os limites dentro dos quais julgará depois, ao determinar providências destinadas à integração de um terceiro no processo, na qualidade de litisconsorte necessário (CPC, art. 47). Ao fazê-lo, amplia subjetivamente a relação processual, acrescendo-lhe um sujeito antes não existente - e com isso cria um cúmulo subjetivo estranho aos termos em que fora deduzida a demanda inicial (infra, n. 576). Rigorosamente, não se pode nesse caso falar em cúmulo ulterior de demandas, pela óbvia razão de que o juiz nada demanda no processo. Mas o resultado lhe equivale, porque o âmbito da sentença passa a ser o mesmo que seria se o autor já houvesse incluído o terceiro, litisconsorte necessário, em sua petição inicial". (Dinamarco, Instituições de direito processual civil, vol. II, 2005, item 478). No entanto, não nos parece que, para os propósitos do presente trabalho, tal ato possa ser considerado demanda, na medida em que o conceito aqui adotado a define necessariamente como ato da parte.
} 
Inicialmente, quando cuidamos das demandas ulteriores, o raciocínio é mais simples. Para se saber se tratamos de reconvenção, denunciação da lide ou mesmo de oposição, podemos nos limitar à análise da função substancial da demanda, é dizer, o propósito que se quer atingir com o ato processual.

A reconvenção é identificada como tal, a partir da formulação de um ato do réu com o objetivo de postular um provimento jurisdicional contrário ao autor e que mantenha algum grau de afinidade com a demanda inicial ou com os fundamentos da defesa do réu. ${ }^{308}$ A denunciação da lide, por sua vez, é identificada pela formulação de um pedido, não contra o autor, mas contra um terceiro, pedido este de natureza eventual; condenação do terceiro caso o pedido do autor seja acolhido contra o denunciante. Por fim, a oposição tem um conteúdo e uma função ainda mais específica: cuida de pedido de terceiro que, no curso de um processo pendente, pretende um provimento jurisdicional apto a conceder, para si, o mesmo bem da vida pleiteado pelas partes deste processo originário.

Para a identificação destes atos postulatórios (demandas ulteriores), é necessário apenas olhar para a causa de pedir e para o pedido mediato formulado pelas partes. Não importa saber a técnica processual (pedido imediato), que é sempre uma só.

Em primeiro lugar, porque sabemos que a reconvenção pode veicular pretensões declaratórias, constitutivas ou condenatórias, e que as demais modalidades normalmente assumirão a modalidade de tutela condenatória.

Em segundo lugar, porque, optando a parte por formular pedido daquela natureza, no curso de processo pendente, não tem ela qualquer escolha quanto ao procedimento a ser seguido, que será sempre aquele previsto pela lei, e somente aquele. ${ }^{309}$

Quando falamos das demandas iniciais, no entanto, a identificação se torna um pouco mais complexa e a consideração do pedido imediato (escolha da técnica processual) passa a ser fundamental. Vimos acima que as possibilidades procedimentais para as demandas iniciais são amplas, tendo em vista que o ordenamento jurídico concede diferentes caminhos (meios fungíveis) para a obtenção da tutela jurisdicional.

\footnotetext{
${ }^{308}$ Em sentido contrário, e seguindo a linha tradicional, Clito Fornaciari Júnior ressalta a necessidade de a reconvenção ser identificada a partir de sua forma, e não apenas conteúdo. Cf. Da reconvenção no direito processual civil brasileiro, p. 159-160.

${ }^{309}$ Esta constatação não impede que uma demanda proposta como o nome de "oposição" ou mesmo de outra categoria de demanda ulterior seja identificada, com base no seu conteúdo, como demanda inicial, a seguir e.g. o procedimento comum ordinária, sendo reunida por conexão a processo pendente. Nesta hipótese, não se trata de aplicar fungibilidade e de se receber "oposição" como "ação ordinária". Diferentemente, significaria apenas a desconsideração do nome e da forma para a identificação do ato que, de acordo com seu conteúdo, deveria ser apenas uma "ação ordinária".
} 
Identificada a espécie de demanda ulterior, já é sabida a competência, a admissibilidade e o procedimento, pois a parte não tem quaisquer condições de escolha quanto a estes aspectos. Identificada espécie de demanda inicial, todavia, nem sempre essa conclusão é imediatamente possível, pois o demandante, formulando o mesmo pedido, poderia lançar mão de mais de um caminho, optando por diferentes técnicas que, à luz dos resultados substanciais, seriam fungíveis. ${ }^{310}$

As consequências deste sistema são as seguintes: mesmo depois de identificada a finalidade do ato (pretensão), é necessária análise adicional, quanto à função processual (objeto processual), é dizer, não basta identificar o ato postulatório por seu objetivo mediato, à luz do direito material, é necessário, além disso, numa terceira análise, identificar a escolha do procedimento (manifestação de vontade quanto à técnica processual), feita pela parte, de modo que se identifique o ato no seu contexto procedimental.

Neste ponto, embora o pedido imediato não tenha relevância para o juízo de individualização da demanda, passa a ser fundamental para o juízo de identificação (cf. item 3.5).

Em suma, podemos afirmar que o ato processual deverá ser classificado como demanda, a partir de seu objeto mediato, é dizer, da circunstância desta veicular pedido de tutela jurisdicional que não se limite à negativa de tutela alheia (bem da vida). No entanto, para que possamos identificar a demanda dentro de uma das subcategorias (especialmente de demandas iniciais), identificando o procedimento pertinente, devemos avaliar - não apenas aspectos substanciais da demanda - mas também a escolha procedimental feita pela parte (pedido imediato), quando esta for admissível.

\subsection{DEMANDA DO AUTOR E DEMANDA DO RÉU}

Conforme vimos acima (item 5.6), no processo civil são admitidas demandas por diferentes sujeitos. Por definição, a demanda inicial é sempre uma demanda do autor, mas este também está autorizado a formular demandas ulteriores no processo, especialmente com a ação declaratória incidental.

${ }^{310}$ Cf. Luiz Yarshell, Tutela jurisdicional, $2^{\mathrm{a}}$ ed., pp. 147-149. 
A demanda do réu, por sua vez, assume o nome de reconvenção e representa a garantia de que a ambas as partes será concedido acesso a uma ordem jurídica justa. ${ }^{311}$ Para Dinamarco, a ação é uma "exigência democrática inerente à garantia do controle jurisdicional e do acesso à justiça", franqueada igualmente aos sujeitos processuais, de modo que ao réu não existe apenas a opção pela defesa (negativa da tutela pleiteada pelo autor), competindo-lhe também a faculdade de contra-atacar, demandando em face do autor tutela jurisdicional e ampliando o objeto litigioso do processo. ${ }^{312}$

A reconvenção tem como características gerais o fato de que constitui uma demanda mediante a qual o réu contra-ataca o autor, no mesmo processo instaurado por aquele, para o fim de formular uma nova pretensão afim à demanda inicial. Esta nova pretensão, por sua vez, não se confunde com uma atividade meramente defensiva, não é mera resistência, mas importa algo mais, que amplia o objeto litigioso do processo e que poderia, a critério do autor, ter dado início a outro processo autônomo. ${ }^{313}$ Assim é a lição de Bondioli:

\begin{abstract}
"a reconvenção é o mecanismo disponibilizado para o réu formular pedido de tutela jurisdicional que lhe traga algo além do programado para o julgamento da demanda inicial (...). Tendo em vista que a ideia de exceção vincula-se, de modo geral, a meios de paralisação de uma demanda anteriormente ajuizada pela parte contrária, fica evidente que reconvenção e exceção em nada se confundem. Enquanto a reconvenção veicula nova e inédita pretensão, agora formulada pelo réu, a exceção se limita a argumentos para a rejeição da demanda ajuizada pelo autor, a fim de evitar o reconhecimento do direito que ele diz ter na sua petição inicial. A medida que a reconvenção aumenta o numero de demandas existente no processo (cumulação ulterior de demandas) e consequentemente estende os limites da sentença (correlação entre demanda e sentença), a exceção mantém inalterados esses aspectos da relação jurídica processual". ${ }^{314}$
\end{abstract}

O objetivo principal desta técnica reside na economia. Com a reconvenção, o legislador visa a aperfeiçoar a eficiência do processo, de modo que, uma vez ampliado o seu objeto, maior parte da relação de direito material, i.e. aspecto mais amplo do conflito, é trazido à apreciação jurisdicional, por meio de um único instrumento, com uma única instrução e com uma única sentença.

\footnotetext{
${ }^{311}$ Instituições de direito processual civil, vol. I, $2^{\mathrm{a}}$ ed., p. 302.

312 Instituições de direito processual civil, vol. I, $2^{\text {a }}$ ed., p. 302.

${ }^{313} \mathrm{Cf}$. Dinamarco. Instituições de direito processual civil, vol. 3, item 1.091.

${ }^{314}$ Cf. Bondioli, Reconvenção no processo civil, p. 26.
} 
As vantagens, com efeito, se dirigem tanto às partes quanto à atividade jurisdicional. $\mathrm{O}$ réu, que poderia ter optado por iniciar outro processo, demanda de forma mais econômica, "evitando a duplicação de atos instrutórios"; mais rápida, "porque não lhe serão impostas as demoras do segundo processo"; e mais segura, "evitando o risco de decisões conflitantes porque, à luz de uma só instrução, as duas demandas serão julgadas em uma sentença só (art. 318)". 315

\subsection{RELAÇÕES ENTRE DEMANDA E DEFESA}

Esclarecido do que se trata uma reconvenção e, ainda, quais são as exigências para que um ato processual possa ser chamado de reconvenção, resta questionar: qual é a diferença entre uma defesa e uma demanda? Qual é a diferença entre uma contestação e uma reconvenção?

A contestação talvez seja o ato postulatório que mais se aproxima da demanda. Não apenas do ponto de vista formal - que em muitos casos pode se identificar com a forma de uma demanda -, mas, sobretudo, do ponto de vista de seu conteúdo. Determina o artigo 300 do Código de Processo Civil que "compete ao réu alegar, na contestação, toda a matéria de defesa, expondo as razões de fato e de direito, com que impugna o pedido do autor".

O dispositivo, além de cuidar do princípio da eventualidade (que não é o objeto do presente trabalho), determina o conteúdo ideal das chamadas defesas de mérito, respostas do réu que, de algum modo, tenham aptidão de influenciar o conteúdo da decisão sobre a pretensão do autor (mesmo que indiretamente). O conceito se dá por exclusão, sendo defesa de mérito toda aquela que não se limite à alegação de vícios processuais (estes, diferentemente, aptos a provocarem decisões jurisdicionais que visem a alterar o curso do procedimento ou a gerar a inadmissibilidade de um ato processual). ${ }^{316}$ Assim a lição de Heitor Sica:

\footnotetext{
“Segundo essa concepção, está compreendida na defesa de mérito, primeiramente, toda a matéria cuja alegação se presta a obter a rejeição da demanda do autor com resolução do seu mérito. Isso
}

315 Cf. Dinamarco. Instituições de direito processual civil, vol. 3, item 1.091.

${ }^{316}$ Cf. Heitor Sica, O direito de defesa no processo civil brasileiro, 2009, p. 89. 
inclui a negativa dos fatos constitutivos do direito do autor, ou da consequência jurídica por ele propugnada (defesa direta) e a oposição de fatos impeditivos, modificativos ou extintivos do direito do autor (defesa indireta, que abrange aqui duas categorias: a exceção substancial, que encerra matérias de mérito não passíveis de reconhecimento de ofício e a objeção substancial, relativa às matérias de mérito cognoscíveis ex officio). Entretanto, o réu pode não se limitar apenas a pedir a rejeição da demanda do autor (defesa sem sentido estrito), mas configurar igualmente contra-ataque, consubstanciado em pedido de tutela jurisdicional plena qualitativa ou quantitativamente diversa da simples rejeição da demanda do autor, hipótese configurada principal, mas não exclusivamente, com a reconvenção”.

O que deve restar muito claro, no entanto, é que o artigo 300 do Código de Processo Civil esclarece a finalidade, o objetivo, do ato postulatório da contestação: apresentar argumentos para a impugnação dos pedidos do autor e a formulação, por consequência, de um pedido específico de tutela jurisdicional, representado pela negação da tutela pleiteada pelo demandante. Bruno Silveira de Oliveira sumariza:

“o que aquele enunciado diz é que a função da espécie postulatória contestação é impugnar o pedido do autor. Aí estão, respectivamente, o consequente (iii) e a hipótese (viii) de uma norma assim estruturada: $\mathrm{H}$ [se o réu deseja impugnar o pedido do autor] $\rightarrow \mathrm{C}$ [deve fazê-lo em contestação]. Isso não significa - reiteremo-lo, ainda que a essa altura pareça óbvio - que o réu deverá intitular "contestação" a peça em que postula a rejeição do pedido do autor". 317

$\mathrm{O}$ ato postulatório que tem por conteúdo a apresentação de "exceções substanciais", por uma parte em referência a demanda de outra parte, e a formulação de um pedido de tutela jurisdicional com o específico conteúdo de negação da tutela pleiteada pela parte contrária é, não pela sua forma, mas pelo seu exato conteúdo, uma contestação, e não uma demanda.

A doutrina esclarece que a contestação, pelo seu conteúdo, e não pela sua forma ou efeito, é o ato que contém pedido de mera rejeição de demanda formulada pela parte contrária. Por consequência deste conteúdo, que deve ser muito claro no "pedido do réu", a contestação - de um modo geral - não tem o condão de ampliar o objeto litigioso do processo: trata-se de um ato de defesa, de recusa aos fundamentos e ao pedido formulado

${ }^{317}$ Bruno Silveira continua "Quer a norma indicar, tão-somente, que a espécie postulatória com que o réu pleiteia a rejeição da pretensão autoral é, qualquer que seja o nome da peça produzida, uma contestação". ( $O$ juízo de identificação de demandas..., 2011, p. 113). 
pelo demandante. ${ }^{318} \mathrm{Na}$ medida em que admite a veiculação de exceções substanciais, a contestação - ao contrário da demanda - tem o condão de simplesmente ampliar o objeto da cognição a ser exercitada pelo juiz da causa, mas tão somente isso (CPC, art. 302 e $334){ }^{319}$

Representado por um pedido com determinada finalidade (mera rejeição da demanda do autor), um ato postulatório pode ser configurado como contestação. Esta configuração jurídica, por sua vez, permite a incidência específica sobre $\mathrm{o}$ ato de determinadas normas, dentre as quais os dispositivos mencionados acima, que configuram os precisos efeitos jurídicos do ato de contestar: ampliação do objeto cognitivo, sem ampliação do objeto litigioso do processo (CPC, arts. 128 e 460).

A identificação do ato, portanto, traz consequências para a determinação de sua eficácia jurídica, e é extremamente relevante quando tratamos de atos de conteúdo similar, assim como ocorre em relação a demandas e defesas.

\subsection{A DEFESA DO RÉU PODE SER INTERPRETADA COMO DEMANDA?}

Como visto, a defesa do réu no processo civil se manifesta de diferentes formas, havendo incialmente uma distinção clara entre as defesas processuais e as defesas de mérito. As primeiras cuidam especialmente do juízo de admissibilidade do julgamento de mérito (pressupostos processuais e condições da ação), é dizer, de questões de natureza preliminar que não influenciam o conteúdo da tutela jurisdicional de mérito, mas são relevantes para viabilizá-la ou não. As segundas, conforme definido por Heitor Sica, são aquelas "que, de algum modo, mesmo que indiretamente, interferem no conteúdo da decisão sobre o fundo da pretensão do autor". 320

Dentro das defesas de mérito, há ainda aquelas em que o réu nada pede para si (e.g. inclusão de litisconsorte passivo necessário, desmembramento do litisconsórcio facultativo, nomeação à autoria e chamamento ao processo) e aquelas em que o réu pede

\footnotetext{
${ }^{318}$ Cf, Chiovenda, "Sulla eccezione", Saggi..., v. 1, p. 151; e Instituições..., v. 1, p. 481; Heinitz, I limiti oggettivi..., p. 215-229.

${ }^{319}$ Cf. Liebman, Manuale di diritto processuale civile..., vol. 1, p. 150; Frederico Marques, Manual..., cit., v. 2, p. 76; e Flávio Luiz Yarshell, Tutela jurisdicional, p. 124.

${ }^{320}$ Cf. Heitor Sica, O direito de defesa no processo civil brasileiro, 2011, p. 205.
} 
tutela jurisdicional de mérito em seu favor, ainda que se limite a pleitear a rejeição do pedido do autor (improcedência).

Nesse quadro, observamos que são muito diferentes de uma demanda (e como ela não podem se confundir) (i) as defesas de natureza processual e (ii) as defesas de mérito nas quais o autor não pede tutela para si. Há postulação e argumentação, mas a finalidade do ato é muito diferente: visa a convencer o juiz a impedir o prosseguimento do procedimento, com sua extinção prematura, ou visa a alterar o quadro dos sujeitos da relação jurídica processual, sem trazer um benefício à luz das relações de direito material em favor do réu.

As defesas de mérito que veiculam pedido de tutela jurisdicional, no entanto, muito se assemelham à demanda, e podem culminar no reconhecimento de direitos em favor do réu, e.g. a alegação da invalidade do contrato que pauta a demanda de cobrança, a alegação da inexistência de vício redibitório, a alegação de culpa exclusiva da vítima em demanda de reparação de danos, a alegação de pagamento em demanda de cobrança, etc. Assim questionamos: tendo em vista esta similaridade, as meras respostas do réu poderiam ser interpretadas como demandas?

Heitor Sica afirma que sim. Seu primeiro fundamento se encontra na ordem constitucional, defendendo que a garantia da ação não concede vantagem em favor do litigante que primeiro toma a iniciativa de litigar, ao passo que as posições do autor e do réu devem ser analisadas com equilíbrio. Seu segundo fundamento reside na defesa da duplicidade do caráter declaratório de toda sentença. A coisa julgada se estabeleceria de modo a imutabilizar o conteúdo declaratório do dispositivo da sentença, seja este de procedência ou de improcedência, de modo que não se poderia negar a circunstância de que o pedido formulado em contestação também poderia, se acolhido, ser estabilizado pela coisa julgada material. A questão ficaria ainda mais clara nas demandas de natureza eminentemente declaratória, nas quais a improcedência do pedido declaratório positivo equivaleria ao acolhimento de um pedido declaratório negativo do réu, ao passo que o acolhimento de uma demanda declaratória negativa seria equivalente ao acolhimento de um pedido declaratório positivo do réu, a respeito da mesma situação jurídica. ${ }^{321}$

\footnotetext{
${ }^{321}$ Heitor Sica ressalta que esta afirmação comporta exceções, afirmando que há hipóteses em que a rejeição do pedido do autor não deve implicar no necessário reconhecimento do "pedido" formulado pelo réu em sua defesa (contestação). Refere-se assim à possibilidade de demanda declaratória que visa a estipular interpretação de cláusula contratual, não acolhendo a sentença nem a interpretação do autor nem a interpretação do réu (cf. Súmula 181 do STJ). Refere-se, também, à possibilidade de o pedido de declaração de nulidade de negócio jurídico do autor ser pautado num fato, e rejeitado na sentença. Esta rejeição não implica na imutabilidade do reconhecimento da validade do contrato, alegada pelo réu, mas na mera negativa
} 
Em função da duplicidade do caráter declaratório de toda sentença, não haveria motivos para se diferenciar o reconhecimento da mesma matéria alegada pela defesa, em sede principal ou em sede incidental, a depender a existência ou não de ação declaratória incidental. Mesmo as questões decididas incidentalmente adquiririam imutabilidade entre as partes, sendo correto afirmar que a reposta do réu (ainda que sem ação declaratória incidental) implicaria nova demanda. ${ }^{322}$

Com base nessas premissas, Heitor Sica sustenta que a defesa de mérito do réu que visa tutela jurisdicional, mesmo que se limite a pedir a improcedência do pedido do autor, pode ser interpretada como uma demanda declaratória, "que invoca seus próprios fundamentos e que, se acolhida, resultará em uma declaração mais ampla do que a simples negativa do direito invocado pelo autor com base na sua respectiva causa de pedir (o que pode ser produzido mesmo sem qualquer intervenção do réu)". Como consequência, "as questões prejudiciais suscitadas pela defesa do réu, que digam respeito à existência ou inexistência das relações jurídicas prejudiciais" ao julgamento de mérito, uma vez reconhecidas na sentença, deveriam ser consideradas como julgadas em caráter principal, integrando o comando decisório sentencial. ${ }^{323}$ Mais a frente em seu trabalho, Heitor Sica ressalta a posição pela qual estaria interpretando a demanda:

\footnotetext{
“não se pode considerar que a parte não demandou apenas porque não usou o verbo 'pedir' ou qualquer se seus sinônimos, ou não se dirigiu ao juiz conjugando no imperativo o verbo 'declarar'. Também se aplica ao processo o comando do art. 112 do Código Civil, no sentido de que '[n]as declarações de vontade se atenderá mais à intenção nelas consubstanciada do que ao sentido literal da linguagem". 324
}

A citada tese, por meio de exemplos, aponta inadequações na concepção tradicional do fenômeno, que não admitiria a interpretação da defesa como uma efetiva demanda. O primeiro usado cuida de demanda de reparação de danos materiais decorrente de acidente de trânsito na qual a sentença, acolhendo a alegação do réu de culpa exclusiva do autor, julgou o pedido improcedente. Esta sentença não impediria a análise de mérito de

de que, para aquele fato (causa de pedir) e aquele pedido o contrato não é nulo. (cf. $O$ direito de defesa no processo civil brasileiro, 2011, pp. 215 e 216).

${ }^{322}$ Heitor Sica, referindo-se às fontes romanas ressalta que "as razões que existiram para justificar essa técnica processual desapareceram e, a despeito disso, alguns doutrinadores continuam a explicar o fenômeno valendo-se da mesma lógica, ou seja, que o julgamento incidenter tantum é fruto de exercício de mera cognitio, ao passo que o julgamento principaliter encerra a iudicio". (cf. O direito de defesa no processo civil brasileiro, 2011, pp. 219-229).

${ }^{323}$ Cf. Heitor Sica, O direito de defesa no processo civil brasileiro, 2011, p. 229.

${ }^{324} \mathrm{Cf}$. Heitor Sica, O direito de defesa no processo civil brasileiro, 2011, p. 237. 
uma segunda demanda, proposta entre as mesmas partes, com base "nos mesmos fatos", embora com pedido de condenação em danos morais. O segundo exemplo cuida de demanda com pedido de abatimento de preço com base em vício redibitório julgada improcedente. Transitada em julgado, a sentença proferida - a despeito de seu conteúdo declaratório - não impediria a propositura de demandas sucessivas, entre as mesmas partes e com base no mesmo vício, agora, no entanto, para a anulação do negócio jurídico ou para a correção do vício do bem.

As situações retratadas seriam inadequadas, pois desperdiçariam relevantes declarações jurídicas a respeito de fatos. Problemas estes que, sequer, poderiam ser solucionados com a ação declaratória incidental, tendo em vista a grande probabilidade de não lhe ser reconhecido interesse processual a tais casos. Vejamos a posição de Heitor Sica:

“os meios tradicionais de contra-ataque postos à disposição do réu (em especial, para os exemplos aqui versados, a demanda declaratória incidental e a reconvencional) não resolvem os problemas retratados, pois é muitíssimo provável que eles fosse rejeitados de acordo com a ideia de que 'o réu obterá o mesmo resultado pela simples defesa'. Os exemplos relevam que essa assertiva está incorreta". 325

Estamos plenamente de acordo que a mera defesa - na sua concepção tradicional - não pode conceder ao réu proteção suficientemente ampla para protegê-lo de uma nova investida do autor, que implique necessidade de se repetir o objeto cognitivo do processo já devidamente solucionado, ainda que de modo parcial. É dizer, o réu não estará protegido da possibilidade de ter de discutir, novamente, se "houve ou não culpa exclusiva do autor" ( $1^{\circ}$ exemplo) ou se "há ou não vício redibitório" no bem contratado ( $2^{\circ}$ exemplo). Entendemos também que está não é a solução mais adequada à luz da técnica processual.

Discordamos, no entanto, da ideia pela qual a ação declaratória incidental do réu não seria meio apto a solucionar o problema. Efetivamente, não há interesse processual para a declaração de fatos, do tipo "a culpa pelo acidente foi exclusiva do autor" ou do tipo “o bem não possui nenhum vício redibitório". No entanto, admitimos o interesse processual para a declaração da inexistência de relação jurídica em concreto, podendo o réu se valer de demanda declaratória incidental para "declarar a inexistência do dever de indenizar por danos morais, materiais ou estéticos" ou mesmo para "declarar a inexistência

${ }^{325}$ Cf. Heitor Sica, O direito de defesa no processo civil brasileiro, 2011, p. 231. 
de direito à redução do preço, de nulidade contratual ou de dever de reparação por vício redibitório". Basta que exista causa de pedir passiva apta a descrever uma verdadeira crise de certeza. Ao fazê-lo, e pelas vias tradicionais, o réu poderia manifestar demandas aptas a trazerem alto grau de proteção em seu favor. ${ }^{326}$

O problema de interpretar defesa de mérito que alega matéria prejudicial ao pedido do autor como demanda reside na circunstância de que o réu, quando se defende, nem sempre manifesta sua vontade, no sentido de que o juiz produza em seu favor os efeitos decorrentes da incidência de fatos a uma norma jurídica de direito material, emitindo um comando (ordem) em face do autor.

Nem sempre há clara formulação de um pedido, no sentido do qual tratamos acima. Demanda é manifestação inequívoca de um pedido que, por sua vez, se fundamenta em uma causa de pedir e que deve afetar a esfera jurídica de determinadas partes. Seu conteúdo é representado pelo projeto de uma norma jurídica concreta: o demandante deseja que por força da ocorrência de determinados fatos (causa de pedir remota) que se submetem ao antecedente de determinada norma (causa de pedir próxima), novos efeitos jurídicos (diferentes da mera recusa dos efeitos desejados pelo demandante) sejam produzidos em concreto (pedido) em relação a determinados sujeitos (partes).

A defesa, diferentemente, representa a vontade do demandando, no sentido de que seja reconhecida a impossibilidade de os fatos narrados pelo autor produzirem os efeitos por ele desejados com o pedido, seja porque estes fatos não ocorreram como narrados (questão de fato), seja porque, ainda que tivessem ocorrido, estes fatos não teriam aptidão jurídica de produzirem os efeitos desejados com o pedido (questão de direito). Negar os efeitos pretendidos pelo autor não implica pedido de que efeitos (diferentes dos pedidos pelo autor) sejam produzidos contra este.

\begin{tabular}{|c|l|}
\hline Conteúdo da demanda & \multicolumn{1}{|c|}{ Conteúdo da defesa de mérito } \\
\hline Vontade: sejam produzidos determinados & Vontade: impedir a produção dos efeitos \\
efeitos (pedido) decorrentes da incidência & desejados pelo demandante (pedido), seja porque \\
\hline
\end{tabular}

\footnotetext{
${ }^{326}$ A jurisprudência fixou o entendimento pela qual o interesse processual na ação declaratória pressupõe a demonstração da existência de dúvida objetiva a respeito da existência de uma relação jurídica concreta: “...

na ação declaratória em que a parte pleiteia que o Estado-juiz declare se é existente ou não uma determinada relação jurídica, mister que paire dúvida objetiva e jurídica sobre a mesma, para que o judiciário não seja instado a definir um pseudo litígio como mero órgão de consulta. Em consequência, não cabe ação declaratória para interpretação do direito subjetivo; bem como para indicar qual a legislação aplicável ao negócio jurídico objeto mediato do pedido. (Luiz Fux, in "Curso de Direito Processual Civil", Vol.. I, $3^{\mathrm{a}}$ Ed., Rio de Janeiro, 2008, págs.. 162/163)". (STJ, 1ª T., REsp 1106764/RJ, Rel. Ministro Luiz Fux, j. 20/10/2009).
} 


$\begin{aligned} & \text { de fatos (causa de pedir remota) a } \\ & \begin{array}{l}\text { determinadas normas jurídicas (causa de } \\ \text { pedir próxima). }\end{array}\end{aligned}$
$\begin{aligned} & \text { não tem aptidão para produzir os efeitos em } \\ & \text { concreto desejados pelo demandante. }\end{aligned}$

Conforme vimos acima, ainda que tenhamos abandonado a referência do nomen iuris e da forma, adotando apenas o conteúdo como referência para o juízo de identificação dos atos postulatórios, concluímos que uma demanda, para ser uma demanda, deve ser inexoravelmente uma demanda, sob pena de prejudicar o contraditório. O problema reside nas legítimas expectativas geradas pela técnica processual vigente em relação aos litigantes, o que acaba por ser determinante na dinâmica do contraditório.

Ainda que de fato exista previsão legal de que o autor deve se manifestar a respeito do conteúdo da contestação, prevendo-se prazo específico para réplica, esta não é suficiente para inserir na mentalidade do autor a ideia pela qual deve responder e impugnar especificamente os fundamentos da "demanda defensiva", sob pena de lhe serem produzidos efeitos distintos da mera rejeição do pedido autoral. ${ }^{327}$

$\mathrm{O}$ primeiro problema reside no princípio da isonomia. O réu teria 15 (quinze) dias para propor sua "demanda defensiva" (CPC, art. 299) ao passo que o autor teria apenas 10 (dez) dias para responde-la: "Se o réu, reconhecendo o fato em que se fundou a ação, outro lhe opuser impeditivo, modificativo ou extintivo do direito do autor, este será ouvido no prazo de 10 (dez) dias, facultando-lhe o juiz a produção de prova documental". O ideal seria que o prazo fosse idêntico para ambos.

Esta distinção não pode ser tomada como irrelevante, ou como de pequena relevância, pois reflete a opção do sistema positivo, no sentido de que a manifestação a respeito de fatos impeditivos, modificativos ou extintivos, alegados pelo réu (e inaptos a produzirem coisa julgada material) não exigiria o mesmo prazo que a resposta prevista, especificamente, para os casos de "verdadeiras" demandas, tal como determina o art. 316 do Código de Processo Civil: "Oferecida a reconvenção, o autor reconvindo será intimado, na pessoa do seu procurador, para contestá-la no prazo de 15 (quinze) dias”.

O segundo problema, por sua vez, reside no risco de o autor subestimar razoavelmente os efeitos que a mera resposta poderia vir a produzir. Nosso direito positivo

\footnotetext{
${ }^{327}$ Heitor defende que sua proposta de interpretação da defesa de mérito como demanda não ofenderia o princípio do contraditório, tendo em vista que "o sistema já prevê (CPC, art. 326) que o autor será intimado a se manifestar sobre os fatos alegados na resposta do réu - na prática, em homenagem à tradição, denomina-se esse ato de 'réplica' (...) o que já é suficiente par que se estabeleça o contraditório sobre a demanda". (Cf. Heitor Sica, $O$ direito de defesa no processo civil brasileiro, p. 269).
} 
não dá sinais suficientemente claros a respeito de a mera defesa poder ampliar o objeto litigioso do processo. Pelo contrário, prevê a reconvenção, a ação declaratória incidental e veda a produção da coisa julgada material em relação às questões prejudiciais (CPC, art. 469).

Desse modo, ainda que se entenda que o sistema vigente é injusto ou inadequado, não é razoável extrair dele o ônus para que o autor, em sede de réplica, se coloque em posição jurídica análoga ao do réu, diante de seu ônus de contestar. ${ }^{328}$ Carente de informações adequadas a respeito de como deve agir e das possíveis consequências de sua contumácia, o autor tem o seu contraditório prejudicado, na hipótese de a mera defesa de mérito ser interpretada como ato apto a expandir o objeto litigioso do processo.

Por este motivo, embora pensemos seja possível a formulação de "demandas informais", no ato da contestação (reconvenções sem peça autônoma), não entendemos que, para tanto, basta alegar exceção substancial. É necessário que, além disso, a vontade de demandar seja inequívoca, de modo que se possa impor ao autor o ônus de uma resposta adequada.

\subsection{O PROBLEMA DAS CHAMADAS EXCEÇÕES RECONVENCIONAIS}

Até o momento, concluímos que, por não existir comunicação inexorável, o mero oferecimento de defesa de mérito (apta a consagrar tutela em favor do réu) não configura e não pode ser interpretada como demanda. Para tanto, deveria existir a manifestação de vontade inconfundível por parte do réu, em ampliar o objeto litigioso do processo, de modo que se formasse - legitimamente - na mentalidade do autor a certeza de que este, não se defendendo adequadamente em réplica, poderia sofrer as consequências impostas pela concessão em seu desfavor de um novo bem da vida, distinto da negativa de seu pleito.

Ocorre, no entanto, que há hipótese na lei processual em que esta afirmação parece estar equivocada. A doutrina italiana, especialmente com referência a Mortara, trata das exceções reconvencionais como um exemplo de situações-limite entre contra-ataque e

\footnotetext{
328 Estes problemas - talvez visando a um sistema processual mais justo - poderiam ser remediados por uma alteração da técnica processual, mediante a previsão expressa da possibilidade de as defesas de mérito serem interpretadas pelo juiz como demanda. Todavia, enquanto não for possível exigir do autor que faça esta interpretação, e que se defenda adequadamente em sede de "réplica", não se mostra adequado - sob o ponto de vista do contraditório - admitir a ampliação do objeto litigioso do processo pela mera alegação de questões prejudiciais em defesa.
} 
defesa. Cuidava dos casos em que o réu trazia em sua defesa "tema novo" para a relação jurídica de direito material que, em si mesmo, poderia figurar como objeto de uma demanda autônoma. Na Itália, os exemplos dados diziam respeito à alegação de compensação e a nulidade ou inexistência de obrigação objeto da demanda que, uma vez analisadas pela sentença, e mesmo sem a formulação de uma demanda pelo réu, seriam passíveis da estabilização pela coisa julgada material. ${ }^{329} \mathrm{O}$ tema também encontra fundamento na Ley de Enjuiciamiento Civil espanhola a qual, em seu artigo 408.3, prevê que a sentença que enfrenta as exceções de compensação e de nulidade do negócio jurídico sofrerá imutabilização da coisa julgada material em relação a estas questões prejudiciais, independentemente de demandas ulteriores. Seria, ainda, possível identificar a exceção reconvencional mesmo no ordenamento jurídico brasileiro. Ao tratar da usucapião de imóveis rurais e urbanos, os artigos $7^{\circ}$ da Lei 6.969/81 e o art. 13 da Lei 10.257/2001 autorizariam que, uma vez alegada a usucapião como matéria de defesa, a sentença passaria a valer como "título para registro no cartório de imóveis". 330

Concordamos com Bondioli, para quem a previsão legal que autoriza a coisa julgada a respeito de questões prejudiciais não faz de uma defesa de mérito uma demanda. ${ }^{331} \mathrm{E}$ isto porque, o conteúdo do ato se mantém íntegro, no sentido de simplesmente resistir à pretensão do autor. ${ }^{332} \mathrm{O}$ caso tratado, ao invés de reforçar a visão que admite a interpretação da defesa de mérito como demanda, ressalta a necessidade de previsibilidade na identificação do ato de demandar.

Explicamos. Ao prever expressamente a possibilidade de o juiz, proferirindo sentença, conceder ao réu tutela mais ampla do que aquela representada pela mera negativa do pedido do autor, a lei - ao invés de criar uma exceção reconvencional - simplesmente relativiza, como faz em muitos outros casos, a regra da inércia e da correlação. Trataremos a seguir de outras hipóteses análogas a estes. O fato, porém, é: há de existir previsão legal expressa para tanto, que excepcione a regra geral do Código de Processo Civil. Além disso,

\footnotetext{
${ }^{329}$ Embora rejeite a utilidade científica do termo "exceção", Heitor Sica ressalta a importância do tema a luz do direito positivo italiano, especialmente considerando o regime preclusivo vigente até a reforma de 1990. (cf. Heitor Sica, O direito de defesa no Processo Civil Brasileiro, pp. 200-201).

${ }^{330} \mathrm{Cf}$. Bondioli, Reconvenção no processo civil, p. 29.

331 Bondioli critica a categoria, ao afirmar que, pelo fato de a ideia de exceção nos remeter, em sua "essência", à mera neutralização de uma demanda, a figura da exceção reconvencional configuraria, em si mesma, uma contradição. "Assim, na medida em que se outorga a uma simples defesa atributos próprios e exclusivos de uma demanda, há uma deformação de conceitos”. (cf. Recovenção no processo civil, p. 29).

332 Em sentido distinto, Heitor Sica entende que o caso não deveria ser caracterizado como uma "categoria específica", defendendo que a hipótese ressaltaria "que a distinção entre defesa e contra-ataque não se baseia em critérios seguros e leva ao menosprezo da posição do réu no processo". Cf. Heitor Sica, $O$ direito de defesa do processo civil brasileiro, 2011, p. 203-204.
} 
é preciso resguardar o contraditório quanto aos requisitos do direito que poderá vir a ser declarado no comando sentencial, o que é feito com base em dois fundamentos.

O primeiro reside na necessidade de alegação da matéria, em sede defesa. Sem a exposição de argumentos o autor, ao responder à contestação, não teria efetivas condições de participar do dialogo processual e, efetivamente, influenciar o conteúdo da decisão judicial. É preciso conhecer para poder eficazmente reagir. O segundo, por sua vez, reside na certeza imposta ao autor, no sentido deste ter de se defender a respeito destas alegações, sob pena de obter tutela jurisdicional desfavorável, para além do objeto de sua demanda.

Esta certeza e previsibilidade, com efeito, não reside na cogitada natureza de demanda da alegação do réu, mas na existência de norma legal que estipula expressamente - a possibilidade de quebra dos limites da demanda pelo juiz, ao decidir a causa. Por este motivo concordamos com Bondioli, para quem somente existirá "exceção reconvencional" mediante previsão expressa de lei. ${ }^{333}$

\subsection{PEDIDO CONTRAPOSTO É DEMANDA?}

Seguindo adiante, resta-nos avaliar se a figura jurídica denominada "pedido contraposto" cuida, na verdade, de uma espécie de demanda. Embora seja comumente utilizado nos foros, na doutrina e na jurisprudência, não há previsão legal, no singular, do termo "pedido contraposto". No plural, apenas, há a expressão "pedidos contrapostos" no artigo 17 da Lei 9.099/95, a qual viabilizaria a formulação conjunta de demandas iniciais entre as partes litigantes de um mesmo processo.

Trataria de hipótese pouco identificada na prática, pela qual as partes em litigio buscariam o Judiciário em conjunto e formulariam "pedidos contrapostos" entre si num mesmo momento inicial. "Desse modo, não há uma única demanda inicial, um único demandante e um único demandado. Há duas ou mais demandas iniciais, dois ou mais demandantes e dois ou mais demandados. Consequentemente, não há sucessividade entre as demandas; não há demanda apresentada na pendência de um processo". 334

A ideia do legislador em permitir este expediente atende à simplicidade e ao objetivo central dos Juizados Especiais Cíveis, que reside no estímulo à utilização de meios

\footnotetext{
${ }^{333}$ Bondioli, Recovenção no processo civil, pp. 30-31.
}

${ }^{334}$ Cf. Bondioli, Recovenção no processo civil, p. 37. 
alternativos de resolução de controvérsias. A partir do fracasso destes, as partes em conjunto poderiam buscar o Judiciário, formulando pedido contraposto.

Diferente e mais relevante é a hipótese tratada pela doutrina no singular, como pedido contraposto. Este sim trataria de uma demanda ulterior do réu em face do autor, formulada em processo em curso, ampliando os limites de seu objeto litigioso. Assim a A lei fala da possibilidade de o réu formular pedido em seu favor no curso de processo pendente, tanto quando trata do procedimento comum sumário (CPC, art. 278, § $1^{\circ}$ ) quanto quando trata dos Juizados Especiais Cíveis (Lei 9.099.95, art. 31). Outras hipóteses são ainda cogitadas por Bondioli:

\begin{abstract}
"Sem o mesmo rótulo, esse fenômeno faz-se presente em outros dispositivos legais, nos quais o legislador ora autoriza a veiculação de determinados pedidos no corpo da contestação (p. ex., demandas possessória e indenizatória apresentadas pelo réu de ação possess6ria que diz ter sido vitima de turbação ou esbulho praticado pelo autor - art. 922), quebrando a regra da exigência de peça própria para a formulação de pedido de tutela jurisdicional pelo réu (art. 299), ora impõe que determinadas defesas do réu somente sejam admissíveis quando acompanhadas pela formulação de uma pretensão (p. ex., na ação consignatória contestada por insuficiência do valor depositado, o réu deve indicar o montante que reputa devido, tanto para viabilizar sua defesa quanto para autorizar a emissão de sentença com eficácia condenatória - arts. 896, IV e $\S$ un., e $899, \S 2^{\circ}$ )”.335
\end{abstract}

Esta previsão simplesmente permitiria que tais procedimentos fossem considerados "ações dúplices" ou tal ato teria efetivamente natureza de reconvenção, com a peculiaridade de ser um ato "menos formal"?

Dos exemplos citados, identificamos que os pedidos autorizados com base no artigo 278, § $1^{\circ}$, do Código de Processo Civil e no artigo 31 da Lei 9.099.95, art. 31 cuidam de um ato postulatório argumentativo do réu, pelo qual este manifesta sua vontade em - inequivocamente - ampliar o objeto litigioso do processo. Vejamos:

Lei 9.099/95. Art. 31. Não se admitirá a reconvenção. É lícito ao réu, na contestação, formular pedido em seu favor, nos limites do art. $3^{\circ}$ desta Lei, desde que fundado nos mesmos fatos que constituem objeto da controvérsia.

CPC. Art. 278. Não obtida a conciliação, oferecerá o réu, na própria audiência, resposta escrita ou oral, acompanhada de documentos e rol de testemunhas e, se requerer perícia, formulará seus

${ }^{335}$ Cf. Bondioli, Recovenção no processo civil, p. 37. 
quesitos desde logo, podendo indicar assistente técnico. $\S 1^{\circ}$ É lícito ao réu, na contestação, formular pedido em seu favor, desde que fundado nos mesmos fatos referidos na inicial.

Pelo seu conteúdo, podemos afirmar que se trata de uma efetiva demanda, com todas as suas características; ato postulatório argumentativo, de natureza essencial, que visa a ampliar os limites do objeto litigioso do processo. Apenas sua forma poderia diferenciá-la de outras demandas iniciais ou ulteriores "típicas". No entanto, como já vimos, a forma não é critério determinante para o juízo de identificação.

Entendemos, assim, que acerta Bondioli ao classificar estes casos de "pedidos contrapostos" como efetiva hipótese de reconvenção, à qual a lei atribuiria um formalismo mais atenuado, com menos requisitos formais de admissibilidade: "A maior informalidade que caracteriza os atos praticados no procedimento sumário e nos Juizados Especiais não interfere na sua natureza. Até porque, como é de se esperar, essa característica mexe com a forma e o modo como os atos são praticados, e não com a sua essência, que permanece inalterada". 336

A mesma lógica da informalidade seria atendida com a possibilidade de o réu formular pedido possessório em face do autor nos curso de demanda possessória proposta em seu desfavor, tal como autoriza do artigo 922 do Código de Processo Civil: "É lícito ao réu, na contestação, alegando que foi o ofendido em sua posse, demandar a proteção possessória e a indenização pelos prejuízos resultantes da turbação ou do esbulho cometido pelo autor".

Estamos diante de um ato postulatório, de natureza argumentativa e que tem como escopo alterar o objeto litigioso do processo. O bem da vida demandado pelo autor foi no sentido de que um dos efeitos do artigo 1.228 do Código de Processo Civil sejam produzidos em seu favor, i.e. restituição da coisa de quem injustamente a possua. O réu, ao formular este "pedido contraposto", não apenas resiste à pretensão do autor, mas pede que este mesmo efeito jurídico seja proferido em seu favor e contrariamente ao réu, isto é, trata-se de pedido que implica necessidade de um novo comando sentencial, o qual não existiria sem esta manifestação de vontade específica do réu. ${ }^{337}$

\footnotetext{
${ }^{336}$ Cf. Bondioli, Recovenção no processo civil, pp. 42-43.

337 A natureza de demanda deste ato depende fundamentalmente da interpretação da lei processual. Somente poderemos considerar este ato como demanda se o concebermos essencial. Caso entendamos que, mesmo que o réu não peça a posse para si, no corpo de sua contestação, o juiz estaria autorizado a fazê-lo, teríamos que entender que a hipótese não cuidaria de reconvenção informal (pedido contraposto), mas de mera exceção legal à regra da congruência.
} 


\subsection{RESPOSTA DO RÉU E EXCEÇÕES LEGAIS À INÉRCIA E À CORRELAÇÃO}

Vimos até o momento que o direito positivo (na identificação de seus atos) considera a função por estes exercida. Com efeito, uma demanda será uma demanda, desde que a manifestação de vontade da parte - pelo seu próprio conteúdo - caracterize o exercício de uma função específica.

Mais do que isso, esta função deve poder ser identificada pela exteriorização do próprio ato: uma demanda para ser uma demanda deve ser inequivocamente uma demanda. Não pode haver dúvidas quanto à vontade da parte em obter um bem da vida mais amplo que a mera rejeição do pedido autoral.

Apenas o ato de vontade da parte que tenha como objetivo veicular pretensão quanto a um bem da vida tem a eficácia de alterar o objeto litigioso do processo. Desse modo foi concebido nosso sistema processual pelo legislador (CPC, art. 128 e 460). Esta é a regra geral, no entanto, a lei prevê exceções; em certas hipóteses e por uma previsão expressa, a lei processual estipula que determinadas condutas meramente defensivas, que não têm como conteúdo a manifestação de vontade clara e expressa quanto à obtenção de um bem da vida, podem acabar por produzir efeitos análogos aos de uma demanda.

Dos exemplos trataremos a seguir. Antes, porém, temos de deixar uma premissa clara: uma demanda não se caracteriza apenas por seus efeitos, mas principalmente pelo seu conteúdo. Se a lei, em determinadas hipóteses (exceções à regra geral) confere a atos defensivos a eficácia de alterar o objeto litigioso do processo, isto não significa que estes atos - porque aptos a produzirem estes efeitos especiais - devem passar a serem considerados demandas.

Se não há uma manifestação de vontade clara, inequívoca, na obtenção de um bem da vida distinto da mera improcedência do pedido do autor, o ato não é uma demanda, pois não exerce a função que a caracteriza. Continuará a ser um ato defensivo ou um mero requerimento, agora, no entanto, com a peculiar e excepcional aptidão de autorizar o juiz a ampliar os limites de sua atuação (objeto litigioso do processo). Simplesmente por uma escolha legislativa.

Esta escolha, por sua vez, ocasiona relativização da inércia e da congruência (CPC, art. 128 e 460). Pressupõe a ponderação de princípios por parte do legislador que, em dados casos e considerando as especificidades da relação de direito material, prioriza a economia e o escopo social do processo para pacificar um aspecto mais amplo da relação 
conflituosa, ainda que inexista pedido de concessão de tutela jurisdicional pelos sujeitos que eventualmente possam vir a ser beneficiados pela sentença. Assim veremos.

\subsection{TUTELA DIFERENCIADA E EXCEÇÕES À INÉRCIA E CORRELAÇÃO}

Os casos de exceção à inércia e à correlação são pontuais e representam a adaptação da técnica processual a situações peculiares, que exigem uma resposta especial da atividade jurisdicional. Normalmente são levados em conta aspectos específicos de determinadas situações de direito material que autorizam modificações, excepcionalidades, na técnica correlata que caracterizam os próprios procedimentos especiais e tutelas diferenciadas. Para Marcato:

\footnotetext{
“a especialidade resulta ora de uma peculiaridade pertinente à relação jurídica material controvertida, ora da necessidade de uma tutela jurisdicional mais rápida; pode ainda resultar de circunstâncias meramente históricas ou então, como ensina Chiovenda, os procedimentos especiais atendem ou a particularidades das formas admitidas para certos grupos de relações jurídicas isoladas, ou, então, à particularidade da cognição". 338
}

Dentre estas especialidades, vimos que a lei pode excepcionar a regra da inércia e da correlação (CPC, art. 128 e 460), autorizando o juiz a conceder bem da vida a quem não formulou pedido no curso do processo. É dizer, autoriza a concessão de tutela jurisdicional, distinta da mera improcedência, a quem não formulou demanda.

Os exemplos de que trataremos pressupõem previsão legal expressa e cuidam dos procedimentos da ( $i$ ) ação de consignação em pagamento (CPC, arts. 896-899); (ii) ação de prestação de contas (CPC, arts. 916-918); (iii) ação revisional de locação (Lei de Locações, art. 68, IV); (iv) ação renovatória de locação (Lei de Locações, art. 72); (v) usucapião especial (Lei 6.969/81, art. $7^{\circ}$ ); e (vi) ação de desapropriação (Decreto Lei 3.365/41).

$\mathrm{Na}$ ação de consignação em pagamento, o art. 896, parágrafo único, do Código de Processo Civil determina que o réu, ao contestar o pedido alegando insuficiência do depósito, tem o ônus de "indicar" o valor que entende devido. Por consequência, o art. 899, $\S 2^{\circ}$, determina que "a sentença que concluir pela insuficiência do depósito determinará,

${ }^{338}$ Cf. Marcato, Procedimentos especiais..., $7^{\mathrm{a}}$ ed., p. 38. 
sempre que possível, o montante devido, e, neste caso, valerá como título executivo, facultado ao credor promover-lhe a execução nos mesmos autos”. Nessa linha, Bondioli entende que a alegação do réu no sentido de o depósito ser insuficiente teria natureza de demanda (reconvenção):

"a conjugação desses dispositivos legais revela que a viabilidade da defesa e a emissão de sentença
condenatória favorável dependem de uma reação ativa do réu na relação jurídica processual, ou
seja, a formulação de pretensão em processo já instaurado. E isso, como se sabe, tem o nome de
reconvenção". ${ }^{339}$

Não concordamos com essa posição. Ao simplesmente alegar em contestação a insuficiência do valor do depósito, a parte está exercendo seu direito de defesa, e não demanda (ou reconvenção). ${ }^{340}$ Não manifesta vontade no sentido de obter um bem da vida distinto da mera negação do pedido do autor, mas simplesmente alega matérias prejudiciais, verdadeiras "exceções substanciais".

A peculiaridade deste caso, com efeito, não está na vontade tampouco no conteúdo ato da parte, o que seria essencial para sua identificação como demanda, mas na lei, que prevê uma exceção à inércia e à congruência. Ao simplesmente se defender, o réu autorizaria o juiz a extrapolar os limites da demanda, concedendo tutela - se for o caso distinta da simples negativa daquela pleiteada pelo autor.

A situação parece ser a mesma na ação de prestação de contas (segunda fase do procedimento de exigir contas ou na fase única do procedimento de dar contas). Apresentadas as contas, o réu tem o ônus de impugná-las, apresentando suas contas na forma mercantil (CPC, art. 916, $\S 2^{\circ}$ e 917). Uma vez apresentadas estas e apurado saldo devedor em favor do réu, a sentença valerá como título executivo quanto à diferença apurada. Tudo isso sem que seja necessário que o réu formule pedido condenatório (CPC, art. 918).

Esta consequência decorre da lei, diretamente, e não de uma demanda. Dizemos isso, pois a mera alegação da incompatibilidade/inadequação do valor não é demanda,

\footnotetext{
${ }^{339}$ Cf. Bondioli, Reconvenção no processo civil, p. 45.

340 Bondioli entende que o ato de indicar o "valor efetivamente devido" configuraria uma verdadeira reconvenção, ou, conforme aduz, "contestação necessariamente acompanhada de reconvenção", ao argumento de que, sem esta indicação, não seria possível a concessão de tutela ao réu mais ampla que a mera improcedência. (Reconvenção no processo civil, pp. 57-58). Entendemos que indicar valor devido não é ato que expõe inexoravelmente a vontade da parte em instituir ou alterar o objeto litigioso do processo, por isso, não configura demanda. Isto, no entanto, não impede que a lei excepcionalmente conceda a este ato meramente defensivo a eficácia de ampliar o objeto litigioso do processo, como de fato o faz.
} 
tampouco poderia ser interpretada como demanda condenatória, face ao autor, para o pagamento das diferenças. Não há manifestação de vontade para que ocorra esta caracterização.

Outro exemplo está na ação revisional de locações. O inciso IV do artigo 68 da Lei de Locações estipula ônus ao réu, para apresentar em sua contestação "contraproposta" ao valor da locação pretendido pelo autor, "se houver discordância quanto ao valor pretendido" da locação que se quer revisar.

Esta proposta, caso acolhida, pode representar a mera procedência parcial do pedido do autor (quando se pleiteia reajuste parcial) ou pode representar um novo "bem da vida" em favor do réu (redução do valor da locação vigente). A partir desta lógica, Bondioli entende que, especialmente no segundo caso, seria necessário concluir que a resposta do réu, ao apresentar "contraproposta" teria "natureza" de reconvenção:

\footnotetext{
"Quando essa contraproposta extrapola o objeto da demanda inicial (p. ex., o autor-locatário tenciona que o valor do aluguel seja revisto para menos e o réu-locador deseja a revisão para fins de majoração), a exigência legislativa faz com que o demandado reaja agindo. Nessas condições, tal contraproposta tem as mesmas características da indicação do montante devido na ação de consignação em pagamento, ou seja, equipara-se a pedido em favor do réu em processo já instaurado. Em outras palavras, trata-se de reconvenção. Novamente, pouco importa para a caracterização do fenômeno reconvenção que a pretensão venha veiculada na mesma peça da contestação (infra, n. 7 e 7.12). Mais uma vez, tudo e pensado para encerrar de uma vez por todas a controvérsia, no caso, com o estabelecimento de valor para o aluguel que reflita as reais condições do imóvel".
}

Também não concordamos com essa assertiva. Na ação revisional, a apresentação de "contraproposta" prevista pelo artigo 68, IV, do Código de Processual é uma mera alegação defensiva; $(i)$ da inadequação de um valor; (ii) da adequação de um outro valor desejado pelo réu. Dizer que a quantia pleiteada pelo autor está equivocada não é demandar, não é reconvir, pois não representa uma manifestação de vontade clara do réu no sentido de que o autor seja condenado ao pagamento de eventuais diferenças, retroagindo-se à data da citação.

Esta condenação, excepcionalmente, se torna possível no caso tratado, não porque houve uma demanda, mas porque a lei autoriza o juiz a condenar sem demanda: "o aluguel fixado na sentença retroage à citação, e as diferenças devidas durante a ação de revisão, 
descontados os alugueres provisórios satisfeitos, serão pagas corrigidas, exigíveis a partir do trânsito em julgado da decisão que fixar o novo aluguel”. (CPC, art. 69).

Situação similar se apresenta no procedimento da chamada "ação renovatória de locações”. Estipula o artigo $72, \S 1^{\circ}$, da Lei de Locações que sempre que o réu alegar que a proposta de renovação do aluguel apresentada na petição inicial não atende ao "valor locativo real do imóvel na época da renovação" este terá o ônus de, “apresentar, em contraproposta, as condições de locação que repute compatíveis com o valor locativo real e atual do imóvel".

Uma vez apresentada esta contraproposta, o juiz estaria autorizado a acolhê-la em sentença, determinando a renovação, de acordo com o valor apresentado pelo réu, e não pelo valor indicado pelo autor, e condenando o autor a pagar "as diferenças dos aluguéis vencidos" (Lei de Locações, art. 73).

A possibilidade de o réu se valer da sentença para executar quantias em dinheiro é tutela jurisdicional distinta da mera improcedência que, em princípio, somente poderia ocorrer por meio de demanda. Ocorre que a lei prevê, também nesta hipótese, uma autorização legal expressa para que o juiz conceda tutela que não foi demandada, ampliando de ofício o objeto litigioso do processo. ${ }^{341}$

Temos, ainda, o exemplo da usucapião especial, prevista pela Lei 6.969/81, do qual já tratamos como exemplo de "exceção reconvencional". Esta prevê em seu artigo $1^{\text {o: }}$ "todo aquele que, não sendo proprietário rural nem urbano, possuir como sua, por 5 (cinco) anos ininterruptos, sem oposição, área rural contínua, não excedente de 25 (vinte e cinco) hectares, e a houver tornado produtiva com seu trabalho e nela tiver sua morada, adquirirlhe-á o domínio".

\footnotetext{
${ }^{341}$ O Superior Tribunal de Justiça parece entender diferentemente, exigido do réu, não apenas a indicação do valor adequado, mas a formulação de pedido expresso, de modo que seja possível a ampliação do objeto litigioso do processo: "PROCESSUAL CIVIL. LOCAÇÃO. AÇÃO RENOVATÓRIA. CARÁTER DÚPLICE. CONTESTAÇÃO. ALTERAÇÃO CONTRATUAL. JULGAMENTO ULTRA-PETITA. OCORRÊNCIA. INTERPRETAÇÃO RESTRITIVA. PEDIDO. 1. Malgrado possua a ação renovatória caráter dúplice, possibilitando ao réu, na contestação, formular pedidos em seu favor, não exigindo reconvenção, caracteriza julgamento ultra petita decisão fixando novo quantum do aluguel, sem que haja requerimento nesse sentido, mas, tão-somente, informação no tocante ao seu valor de mercado. 2. O pedido deve ser interpretado restritivamente (art. 293-CPC), ou seja, há necessidade de invocação expressa da pretensão pelo autor e, na espécie, também pelo réu. 3. Recurso especial conhecido e provido"(STJ, 6 ${ }^{\mathrm{a}} \mathrm{T}$., REsp 285.472/SP, Rel. Ministro Fernando Gonçalves, j. 16/10/2001, DJ 05/11/2001, p. 147).

Buzaid, referindo-se a procedimento similar previsto pelo Dec. 24.150, afirma que: "o processo de renovação de arrendamento pertence à categoria dos processos mistos ou dúplices, assim chamados porque neles é idêntica a condição dos litigantes, de modo que o autor pode tornar-se réu e o réu, autor. O autor propõe ação porque pretende renovação; o réu na contestação pode alegar: a matéria constante do art. $8^{\circ}$ do Dec. 24.150 (...) A defesa do réu, conforme seu alcance, pode ampliar não apenas o objeto de conhecimento, mas também o objeto da sentença”. (Da ação renovatória, pp. 393-394).
} 
Além das peculiaridades do direito material, que facilitam o reconhecimento da usucapião, a norma citada tem repercussões específicas para o processo civil, ao prescrever em seu artigo $7^{\circ}$ : “A usucapião especial poderá ser invocada como matéria de defesa, valendo a sentença que a reconhecer como título para transcrição no Registro de Imóveis". 342

A lei, nesse sentido, excepcionando a regra geral do Código de Processo Civil que, inclusive, exige procedimento especial para as demais hipóteses de usucapião, admite que a mera alegação em defesa de "aquisição da propriedade pela usucapião especial" autorizaria - mesmo sem nenhuma demanda - a ampliação do objeto litigioso do processo, passando esta "questão prejudicial" a ser decidida em caráter principal na sentença, como se houvesse sido formulada ação declaratória incidental para tanto.

Por fim, temos o procedimento da ação de desapropriação previsto pelo Decreto Lei 3.365/41, que também autoriza tutela em favor do réu de natureza distinta da mera improcedência do pedido do autor. A peculiaridade deste procedimento é que, enquanto nos outros casos tratados é a conduta do réu que normalmente autoriza a ampliação do objeto litigioso do processo, ainda que esta não cuide de demanda, no caso da desapropriação o réu poderá obter tutela ainda que se omita (sem nenhuma defesa sequer):

\footnotetext{
“Aliás, o $\S 1^{\circ}$ da art. 27 do decreto lei n. 3.365, de 21 de junho de 1941 (Lei das Desapropriações), trata expressamente do conteúdo da sentença que fixa indenização em patamar superior à oferta, o que mostra ser esse um fato programado para a ação de desapropriação. E a programação de sentença com essas características não exige nenhuma atitude do demandado, nem mesmo defensiva". ${ }^{343}$
}

Nesta hipótese, a relativização da inércia e da congruência é ainda mais clara, pois a tutela jurisdicional pode ser conferida ainda nos casos de contumácia do réu, defendendo-se ou não o réu poderá obter em seu favor bem distinto - e mais favorável que a mera rejeição do pedido do autor. A depender da perícia de avaliação do imóvel, a

\footnotetext{
${ }^{342}$ O Superior Tribunal de Justiça, reconhecendo as especificidades da usucapião especial e da função social apresentada pela norma, ratificou a possibilidade de sentença que julgou improcedente ação reivindicatória, ao acolher a alegação de usucapião especial do réu, pode ser levada a registro de domínio em favor este. Vejamos ementa: "Usucapião especial. Art. $7^{\circ}$ da Lei $n^{\circ}$ 6.969/81. Registro da sentença que reconhece a usucapião especial. 1. A regra do art. $7^{\circ}$ da Lei $\mathrm{n}^{\circ} 6.969 / 81$ é expressa ao admitir que a "usucapião poderá ser invocada como matéria de defesa, valendo a sentença que a reconhecer como título para transcrição no registro de imóveis". 2. Matéria de prova não se examina em recurso especial (Súmula nº 07 da Corte), o mesmo ocorrendo com matéria que não foi objeto sequer do recurso de apelação. 3. Recurso especial conhecido em parte, e, nessa parte, provido. (STJ, $3^{\mathrm{a}}$ T., REsp 233.607/SP, Rel. Ministro Carlos Alberto Menezes Direito, j. 18/05/2000, DJ 01/08/2000, p. 270)

${ }^{343} \mathrm{Cf}$. Bondioli, Reconvenção no processo civil, pp. 67-68
} 
sentença pode condenar o autor a pagar indenização pela desapropriação em quantia mais alta que aquela contida no pedido inicial.

Em conclusão: defesa e demanda se distinguem pelo conteúdo da exteriorização do ato da parte (função), e não pelo nome, pela forma ou mesmo pelos efeitos que produzem. Desse modo, se excepcionalmente a lei concede à defesa efeito análogo ao que concede às demandas, de um modo geral, esta não deixará de ser o que é. Trata da exceção que comprova a regra. Mais do que isso, conforme demonstra o exemplo da ação de desapropriação, esta possibilidade de acréscimo do objeto litigioso do processo ou de se conceder o que não foi demandado é controlada pelo direito positivo, e pode ocorrer desde que exista previsão expressa da lei - mesmo nos casos em que o réu sequer se manifesta no processo.

\subsection{AÇÕES DÚPLICES E DEMANDA DO RÉU}

Até o presente momento, referimo-nos em diferentes momentos - e de forma aleatória - à expressão "ações dúplices", mas seria este um conceito seguro, que denota fenômenos uniformes? Seria útil sua utilização? Tendemos a crer que não. ${ }^{344}$

Sabemos que o termo é usado pela doutrina para designar fenômenos dos mais variados, dentre os quais as ( $i$ ) ações possessórias, que possibilitariam a tutela da posse ao réu, independentemente de demanda deste; (ii) procedimento comum sumário e procedimento sumaríssimo dos Juizados Especiais Cíveis; (iii) ação de consignação em pagamento (CPC, arts. 896-899); (iv) ação de prestação de contas (CPC, arts. 916-918); (v) ação revisional de locação (Lei de Locações, art. 68, IV); (vi) ação renovatória de locação (Lei de Locações, art. 72); e (vii) usucapião especial (Lei 6.969/81, art. $7^{\circ}$ ). ${ }^{345}$

Em geral, nestes casos, ao simplesmente "contestar", o réu poderia vir a ser contemplado com tutela jurisdicional distinta da mera negativa do direito demandado pelo autor. ${ }^{346}$ Ocorre que já verificamos que as situações acima tratadas não são uniformes. Sob

\footnotetext{
344 A expressão teria referência na "actio duplex" do direito romano, Cf. Kazuo Watanabe, "Ações dúplices", RePro 31, 1983, p. 138.

${ }^{345}$ Cf. Kazuo Watanabe, “Ações dúplices”, RePro 31, 1983, p. 141 e ss.

346 Flávio Luiz Yarshell ressalta que a contestação na ação dúplice não se confundiria com uma reconvenção, por faltar naquela o requisito da autonomia. A pretensão manifestada em contestação de ação dúplice, segundo o processualista, não poderia ser reproduzida em "ação autônoma", o que lhe retiraria a natureza de demanda. Ao contestar ação dúplice, o réu não formularia demanda, diferentemente do que
} 
o nome "ação dúplice" acaba por se esconder uma multiplicidade de fenômenos, muitos deles complemente heterogêneos, i.e. há ações dúplices que $(i)$ simplesmente representam a possibilidade de o réu formular reconvenção (pedido contraposto) contra o autor na peça de contestação; e que (ii) autorizariam ao juiz flexibilizar a inércia e conceder ao réu tutela diferente da simples negativa do pedido do autor e independentemente de qualquer pedido.

Vimos acima que o procedimento do juizado especial cível, o procedimento sumário e o procedimento das ações possessórias prevê expressamente a possibilidade de o réu apresentar reconvenção simplificada, sem a necessidade de uma peça autônoma. A partir desta demanda ulterior o objeto litigioso do processo seria ampliado e o juiz, por consequência, estaria autorizado a conferir ao réu tutela distinta da mera negativa da tutela do autor.

Vimos, também, que em outros procedimentos a possibilidade de ampliação do objeto litigioso do processo estaria condicionada a determinadas condutas defensivas do réu (que não configuram demandas), assim como ocorre na ação de consignação em pagamento, na ação de prestação de contas, na ação revisional, na ação renovatória e na usucapião especial alegada em defesa (cf. item 5.14).

Em função destas circunstâncias, Bondioli afirma que seria errado tratar dos casos citados acima como hipóteses de "ações dúplices". Para o processualista, somente o seriam aquelas capazes "de proporcionar tanto para o demandante quanto para o demandado uma tutela jurisdicional de igual qualidade, independentemente da oferta de qualquer demanda, pedido e até defesa por parte deste, em razão de peculiaridades da relação de direito material existente entre as partes, do pedido de tutela formulado e de sua disciplina legal". 347

Bondioli reconhece que toda demanda tem "um certo grau de duplicidade", na medida em que a improcedência traria consigo "uma ação declaratória negativa do direito invocado pelo autor". No entanto, compreender assim as ações dúplices seria relegar o conceito à inutilidade, de modo que sua proposta seria restringi-lo aos casos em que "o julgamento da demanda traz para o réu algo mais do que a simples negativa do direito invocado pelo autor". 348

Dito isso, questionamos: quais seriam as “verdadeiras ações dúplices”?

ocorreria na reconvenção e mesmo no pedido contraposto. O processualista cuida da questão ao tratar da resolução do contrato por onerosidade excessiva, prevista pelo art. 479 do Código Civil, que viabilizaria ao réu uma oferta de revisão do contrato como matéria de defesa. (Resolução do contrato por onerosidade excessiva, p. 569).

${ }^{347}$ Bondioli, Reconvenção no processo civil, pp. 49-50.

${ }^{348}$ Bondioli, Reconvenção no processo civil, pp. 50-51. 
Para Bondioli "ações dúplices" seriam basicamente aquelas com conteúdo declaratório: "Malgrado o seu desfecho em favor do réu traga simples declaração da inexistência do direito invocado pelo autor, a sentença emitida nestas circunstâncias dá ao demandado tutela de igual qualidade à que concederia ao autor no caso de procedência do pedido". O processualista cita ainda como exemplos de ações dúplices (i) o procedimento da "ação de divisão e demarcação de terras particulares" previsto pelos artigos 946 a 981 do Código de Processo Civil; (ii) a ação de restauração de autos; (iii) ação de desapropriação. ${ }^{349}$

De fato, as demandas declaratórias têm a peculiaridade de que tanto as sentenças de procedência quanto as de improcedência têm uma mesma "natureza", são simplesmente declaratórias. O mesmo não se dá (i) nas condenatórias, cuja improcedência é declaratória, mas cuja procedência impõe o cumprimento de uma prestação (condenatória); (ii) constitutivas, cuja improcedência é declaratória, mas cuja procedência implica criação, modificação ou extinção de situação jurídica (constitutiva).

Ocorre que, a partir desta constatação, atribuir à procedência a mesma qualidade da sentença de improcedência pressupõe a delimitação do que seria, efetivamente, esta "qualidade". Isto porque negar a inexistência não significa declarar a existência e, do mesmo modo, negar a existência não significa declarar a inexistência.

A demanda declaratória negativa (de inexistência de relação jurídica), julgada improcedente, não significa tutela declaratória para o réu reconhecendo a existência da relação jurídica processual.

O autor não tem o ônus de trazer em sua demanda declaratória negativa todas as causas de pedir possíveis, sob pena de preclusão (não há esta eventualidade para o autor). Por este motivo, a improcedência do pedido declaratório negativo simplesmente reconhece a não inexistência da relação jurídica por aqueles fundamentos invocados, não nega a possibilidade de a mesma relação jurídica alegada inexistir por outro fundamento. Referindo-se à questão, assim se manifesta André Iglesias:

\footnotetext{
"A sentença de improcedência apenas reconhecerá a impossibilidade de se declarar a inexistência por aquele fundamento. Se para julgar improcedente a sentença considerar que a obrigação existe, o estará fazendo extra petita, pois outros eventuais fundamentos de inexistência não formam
}

${ }^{349}$ Bondioli, Reconvenção no processo civil, pp. 65 e ss. 
objeto do processo e o contraditório do autor restaria violado. Ademais, ainda assim, tal 'reconhecimento' estaria apenas na motivação, não sendo abrangido pela coisa julgada". ${ }^{350}$

Do mesmo modo, ação declaratória positiva (de existência de relação jurídica), julgada improcedente, não representa tutela declaratória em favor do réu pelo reconhecimento da inexistência da relação jurídica. A sentença simplesmente nega o pedido qualificado pelos seus fundamentos, decretando que não é possível afirmar existente determinada relação jurídica com base em determinado fundamento. Não impede que esta mesma relação venha a ser considerada existente por outro motivo, não invocado naquela demanda.

Assim como ocorre nas demandas condenatórias ou constitutivas, a improcedência significa simplesmente $(i)$ que não ocorreram os fatos narrados como causa de pedir; ou (ii) que, ainda que ocorridos, os fatos narrados não têm aptidão para produzir os efeitos pleiteados. Vejamos exemplos.

O contratante visa a obter a declaração da nulidade absoluta de contrato que celebrou, com fundamento de que, por causa transitória, não teve condições de manifestar adequadamente sua vontade no ato de celebração do contrato (CC, art. $3^{\circ}$, III e art. 166, I). A sentença que reconhece a inexistência desta "causa transitória" e que julga improcedente o pedido tem conteúdo declaratório. Este conteúdo declaratório, todavia, não se estabelece para declarar a validade do contrato, mas simplesmente para negar o pedido que, por sua vez, se identifica pela causa de pedir, i.e. inexistência da nulidade daquele contrato com base em "causa transitória" para a incapacidade absoluta do agente.

Outro exemplo cuidaria do caso inverso. Ação declaratória de existência de relação jurídica cambial, ao argumento de que houve aceite em duplicata, julgada improcedente, não implica na declaração da inexistência de relação jurídica cambial. Caso a sentença tenha se pautado na inexistência de aceite, esta apenas nega a nulidade do título de crédito com base neste fundamento, não nega a existência de relação cambial. Esta ainda poderia existir, caso se demonstrasse posteriormente que o caso cuidaria de hipótese em que o aceite é desnecessário (Lei 5.747/68, art. 13). A negativa do pedido de existência não implica no reconhecimento da inexistência de relação jurídica.

Tudo isso é uma consequência de fenômeno do qual tratamos anteriormente: o pedido apenas poder ser compreendido à luz da causa de pedir que lhe dá fundamento.

${ }^{350}$ Cf. André de Freitas Iglesias, Da sentença que 'reconhece a existência de obrigação' como título executivo (CPC, art. 475-N), 2007, pp. 116-117. No mesmo sentido, cf. Arruda Alvim, Manual de direito processual civil, v. 2, p. 538; e Talamini, Coisa julgada e sua revisão, p. 75-77. 
Acolhê-lo ou rejeitá-lo significa analisar aquele objeto litigioso específico, devidamente individualizado pelas partes e pela causa de pedir (ativa e remota). ${ }^{351}$

Assim, entendemos que a suposta duplicidade, em relação às demandas declaratórias, não descreve fenômeno qualitativamente distinto das demais espécies de tutela jurisdicional. A improcedência se limita a negar os efeitos daquele determinado pedido à luz daquela causa de pedir invocada.

Quanto aos demais exemplos citados, cuidamos de hipóteses da já mencionada possibilidade de se excepcionar a inércia e a congruência, concedendo ao réu - de ofício ou mediante simples alegação de defesa de mérito - bem da vida distinto da mera improcedência do pedido do autor.

No procedimento de demarcação de terras é muito clara a possibilidade de o processo, mesmo sem demanda dos réus, acarretar sentença que determine a demarcação em seu favor (CPC, art. 958). Esta pode ser representada pela mera improcedência do pedido do autor, pela rejeição de sua proposta de demarcação, fixando-a favoravelmente aos réus. Pode, ainda, e dependendo da interpretação do pedido, configurar bem jurídico distinto, demarcando o imóvel de modo, não quantitativamente distinto, mas qualitativamente distinto do proposto pelo autor.

Não negamos seja a distinção muito tênue, que deverá pressupor a interpretação do pedido a identificação das circunstâncias específicas do caso concreto. No entanto, o que importa saber que é, se necessário, a lei concede ao juiz, neste procedimento, a autorização especial para desrespeitar a inércia e os limites da congruência, sempre visando ao escopo jurídico e social do processo.

Exatamente o mesmo pode ser dito a respeito da ação de desapropriação. A este respeito já nos manifestamos anteriormente, afirmando que, neste procedimento, o réu poderá obter tutela - diferente da mera rejeição do pedido do autor - ainda que se omita. $\mathrm{O}$ $\S 1^{\circ}$ da art. 27 da Lei das Desapropriações permite indenização em favor do réu em patamares superiores aos da oferta do autor, "o que mostra ser esse um fato programado

351 É evidente que há hipótese de ação declaratória que a improcedência parece representar tutela qualitativamente idêntica à procedência, embora de conteúdo oposto. Este é o caso da ação declaratória de paternidade, a qual, julgada improcedente, tem o mesmo efeito de uma ação declaratória de ausência de paternidade julgada procedente. Ocorre que neste caso, o efeito é gerado em função da natureza da causa de pedir, que se pauta, não em um fato, mas em um estado de fato: a paternidade. Ou se é pai, ou se é não pai. Não há margem para outras possibilidade, assim como ocorre em relação aos negócios jurídicos, títulos de créditos e atos administrativos. Nestes, não ser nulo (por um determinado fundamento) não significar ser válido. 
para a ação de desapropriação. E a programação de sentença com essas características não exige nenhuma atitude do demandado, nem mesmo defensiva". 352

Por fim, quanto ao caso do procedimento de "restauração de autos", mencionada por Bondioli como exemplo de ação dúplice, entendemos tratar-se de caso de jurisdição voluntária, na qual sequer há na necessidade de se falar em quebra destas exigências, pela inaplicabilidade da inércia e da congruência (CPC, art. 1.063).

Assim, pensamos que o conceito de ações dúplices não é útil, pois não retrata um fenômeno uniforme, mas na verdade situações muito diferentes, pelas quais a tutela jurisdicional pode ser concedida ao autor ou ao réu, pela (i) eficácia da sentença da sentença de improcedência (mera rejeição do pedido do autor); ou (ii) pela relativização da inércia e da congruência, em casos excepcionalmente previstos pela lei.

${ }^{352}$ Cf. Bondioli, Reconvenção no processo civil, pp. 67-68 


\section{CONGRUÊNCIA: DEMANDA E TUTELA JURISDICIONAL}

\subsection{CONSIDERAÇÕES INICIAIS}

Até o presente momento, preocupamo-nos em desenvolver critérios para a individualização e identificação da demanda, com o objetivo primordial de assentar as premissas necessárias para que, no presente capítulo, pudéssemos tratar adequadamente da relação entre demanda e tutela jurisdicional.

Os pressupostos da análise da correlação se encontram em saber (i) "o quê" se pleiteia e (ii) "por meio do quê" se pleiteia. Sem uma devida delimitação destes dois fatores, não é possível estabelecer as relações entre demanda (provocação da Jurisdição) e tutela jurisdicional (resultado do processo).

O juízo de individualização, ao expor os elementos que delimitam o objeto litigioso do processo, é a atividade designada para solucionar o primeiro ponto do debate, i.e. aquilo que se exige do Estado (Cf. Capítulos 3 e 4). O juízo de identificação da demanda, por sua vez, permite a análise do veículo usado para provocar o Estado-juiz, i.e. se se trata de uma demanda (apta a justificar uma resposta Jurisdicional específica) ou se se trata de mero requerimento ou defesa ou recurso, inapto a instaurar ou modificar de uma forma geral o objeto litigioso do processo (cf. Capítulo 5).

Há variados atos similares à demanda que não têm o condão de gerar a mesma eficácia jurídica, e.g. requerimentos de tutela de urgência, exceções substanciais e recursos (cf. Capítulo 5). Ademais, dentro de uma demanda, há um número infindável de informações, restando extremamente complexo o trabalho de interpretação deste ato e de definição do conteúdo da manifestação da vontade, a ser respondida pelo Estado-juiz (cf. Capítulo 4).

Solucionados estes problemas, partiremos no presente capítulo a estudar a relação entre demanda e tutela jurisdicional a partir da regra da congruência. 


\subsection{RELAÇÕES ENTRE DEMANDA, SENTENÇA E TUTELA JURISDICIONAL}

A congruência é tradicionalmente estabelecida pela comparação de dois atos processuais; a demanda e a sentença, sendo normalmente usada para fundamentar a nulidade dos atos decisórios do juiz que $(i)$ decidem menos do que foi demandado (sentença infra petita); (ii) decidem mais do que foi demandado (sentença ultra petita); e (iii) decidem algo distinto do que foi demandado (sentença extra petita).

Tratamos da "coerência ou correspondência lógica, como comparação ou confrontação entre o demandado pelas partes e a parte dispositiva da sentença". ${ }^{353}$ Assim Jaime Guasp:

"Puede ser definida como la conformidad que debe existir entre la sentencia y la pretension o pretensiones que constituyen el objeto del processo, más la oposición o oposiciones en cuanto delimitan este objeto. Es, pues, una relación entre dos términos, uno de los cuales es la sentencia misma, mas concretamente su fallo o parte dispositiva, y otro el objecto procesal en sentido riguroso; (...) la pretension procesal...". ${ }^{354}$

A definição é correta, no entanto, reflete apenas parcialmente o problema. O moderno processo civil - retratado pela exigência de efetividade - propõe uma migração do polo de estudos da ação e da sentença para a tutela jurisdicional e está mais preocupado com as transformações que a atividade jurisdicional tem a produzir no âmbito social, do que com a mera construção de atos formais (postulatórios, decisórios, etc.) e a produção de efeitos meramente jurídicos. ${ }^{355}$

A relação lógica entre demanda e sentença é importante, e deve ser ressaltada. A sentença não pode extrapolar, refugar ou tampouco desapontar os limites da demanda, pois ao fazê-lo - e conforme demonstraremos a seguir - estaria ofendendo uma série de princípios constitucionais do processo, tais como a inércia, a inafastabilidade e o

${ }^{353}$ Cf. Guilhermo Jorge Enderle, La congruencia procesal, 2007, p. 57.

${ }^{354}$ Cf. Jaime Guasp, Derecho procesal civil, p. 533.

355 Para Dinamarco, efetividade do processo representa sua "capacidade de exaurir os objetivos" que legitimam o processo. Para o processualista "o empenho em se operacionalizar o sistema, buscando extrair dele todo o proveito que ele seja potencialmente apto a proporcionar, sem deixar resíduos de insatisfação por eliminar e sem se satisfazer com soluções que não sejam jurídica ou socialmente legítimas, constitui o motivo central dos estudos mais avançados, na ciência processual da atualidade". (A Instrumentalidade..., $12^{\mathrm{a}} \mathrm{ed}$., p. 326). Barbosa Moreira, na mesma linha de raciocínio, ao referir-se ao tema, propõe um 'programa básico' da campanha em prol da efetividade do processo. ("Efetividade do processo e técnica processual", Temas... Sexta série, pp. 17 e 18). 
contraditório. Todavia, a sentença não é o ato fim da atividade jurisdicional, em muitos casos, é mero pressuposto de atividade ulterior capaz de satisfazer a pretensão das partes (especialmente nas tutelas condenatórias).

Por este motivo, entendemos não ser possível limitar o estudo da correlação à sentença, é necessário que este seja analisado sob a perspectiva de toda a atividade jurisdicional: do início (demanda) ao fim (tutela jurisdicional). ${ }^{356}$

O Estado não está proibido de decidir diferentemente ou ir além ou aquém do demandado apenas na fase cognitiva do processo (encerrada com a sentença). Esta proibição continua até o momento em que é entregue a tutela jurisdicional. Por este motivo, nos itens seguintes, trataremos da correlação sob a perspectiva da demanda e da tutela jurisdicional, e não apenas sentença, e incluiremos ao estudo do objeto litigioso do processo $(i)$ o dever de respeito ao conteúdo da demanda/sentença, na fase de cumprimento desta; e (ii) as exceções aplicáveis a esta regra.

\subsection{JUSTIFICATIVAS AXIOLÓGICAS DA CORRELAÇÃO}

A principal das limitações impostas pela Constituição ao processo - e que se relaciona intimamente com a função da demanda - é representada pela inércia (nemo judex sine actore e nemo iudex procedat ex officio), e pelo princípio do contraditório (audiatur et altera pars); a Jurisdição não atua sem ser provocada e não soluciona conflitos sem antes dar oportunidade de participação aos interessados.

A formação do processo depende de um ato da parte, de natureza postulatória. Salvo exceções pontualmente previstas pela lei, é a demanda, e somente a demanda, que permite retirar o Estado da sua posição de inércia, autorizando-o a "investigar" a ocorrência de determinados fatos (veracidade das alegações das partes), a incidência destes fatos a determinadas normas jurídicas (subsunção ou proporcionalidade) e a viabilidade de produção dos efeitos jurídicos pleiteados pelo demandante, para (i) em resposta positiva,

\footnotetext{
356 É imperioso ressaltar que a correlação de que tratamos no presente trabalho se dá entre demanda e tutela jurisdicional, não se tratando de uma correlação ou exigência de coerência interna à sentença. A consideração é importante, na medida em que há na doutrina a diferenciação entre correlação interna e correlação externa, de modo que a primeira existiria entre os "considerando" ou fundamentos da sentença e sua parte dispositiva, ao passo que a segunda estaria entre a demanda e o dispositivo da sentença. A este respeito, e especialmente à jurisprudência argentina de trata do tema, cf. Guilhermo Jorge Enderle, $L a$ congruencia procesal, 2007, p. 95 e ss.
} 
permitir a sua concretização (procedência), ou (ii) em resposta negativa, declarar inviáveis aqueles efeitos pleiteados (improcedência), ou mesmo a inviabilidade do próprio julgamento de mérito (inadmissibilidade).

Esta autorização para agir, atuar e prestar a tutela jurisdicional é em todos os momentos condicionada ao pleno respeito ao contraditório e à ampla defesa. $\mathrm{O}$ conteúdo da demanda proposta deve ser apresentado ao demandado, que deve ter condições efetivas compreendê-la (informação) e, se julgar necessário, realizar todos os atos pertinentes ao convencimento do juiz, para que não a acolha (possibilidade de reação adequada).

Nesta linha, Satta e Punzi desenvolvem o argumento pelo qual a real dimensão da demanda somente pode ser concebida a partir do princípio do contraditório, no qual se reflete a bilateralidade da relação jurídica processual. Para os autores, "postular um julgamento favorável implica afirmar um direito no confronto com outro sujeito, e esta afirmação é essencialmente uma demanda". Embora formalmente a demanda seja apresentada ao juiz, sustentam que do ponto de vista material esta seria direcionada à parte contrária, e isto porque "somente nos seus confrontos a afirmação de um direito pode ter um sentido e um valor". 357

A demanda, portanto, autoriza o agir da Jurisdição e serve de referência para todos os sujeitos processuais, a respeito do objeto trazido a debate no processo, por meio do contraditório. Não apenas serve para provocar a Jurisdição, mas também para delimitar sua atuação e para delimitar o próprio objeto do contraditório (objeto cognitivo e objeto litigioso do processo).

E mais. Ao lado destas exigências, encontra-se a garantia constitucional de inafastabilidade e de acesso à justiça, que esclarece que ao Estado é vedado recusar manifestação a respeito de demanda formulada. Quebrada a inércia, cabe à Jurisdição dar acesso, não apenas ao processo, mas a uma resposta adequada e completa. Conforme leciona Barbosa Moreira:

\footnotetext{
“Ao juiz é proibido exceder o pedido ou julgar fora do pedido, mas não nos esqueçamos de que há o dever, para o juiz, de pronunciar-se sobre todo o pedido; nada além do pedido, mas todo o pedido. $\mathrm{O}$ vício de uma sentença que não julga o pedido por inteiro é tão grave quanto o vício de uma sentença que extravasa os limites do pedido. O chamado vício do julgamento citra petita é tão grave quanto o do julgamento ultra ou extra petita. Há exemplos muito óbvios, como o de ações cumuladas, inclusive no caso de ação primitiva e reconvenção porventura oferecida pelo réu. Se a
}

${ }^{357}$ Diritto processuale civile, $13^{\mathrm{a}}$ ed., 2000, p. 139. 
sentença esquece uma das ações e só julga a outra, ou as outras, essa sentença padece do vício citra petita e é tão defeituosa quanto a sentença que julgasse ultra petita ou que julgasse extra petita". ${ }^{358}$

Embora trate de uma norma infraconstitucional (CPC, art. 128 e 460), a correlação tem fundamentos constitucionais, na medida em que concretiza os citados princípios. Para Dinamarco "a regra ne eat judex ultra vel extra petita partium é filha do nemo judex sine actore, porque na parte que não corresponde à demanda o juiz estaria decidindo sem a indispensável iniciativa de parte". ${ }^{359}$ E mais do que isso, decidir algo distinto do que foi demandando é decidir sobre matéria que - em princípio - não foi submetida ao contraditório e a respeito do qual o demandado não teve a oportunidade de se defender (ampla defesa), acarretando também ofensa a estes dois últimos princípios. ${ }^{360}$

Da conjunção destes fatores, demanda, inércia, contraditório e inafastabilidade, nasce a exigência de correlação i.e. a proibição de se conceder ao demandante algo a menos, a mais ou diferente do que foi pedido (julgamentos infra, ultra e extra petita). A correlação existe porque o Estado-juiz é obrigado a responder à demanda (inafastabilidade) e pode apenas apreciar aquilo que foi efetivamente demandado (inércia), nada a mais, nada a menos e nada diferente.

Somente aquilo que foi demandado foi submetido ao contraditório; "sair" ou "ir além" significaria decidir sobre o que não foi debatido, ou sobre fatos e direitos a respeito dos quais os sujeitos processuais sequer tiveram a oportunidade de se manifestar (contraditório e ampla defesa). ${ }^{361}$

${ }^{358}$ Barbosa Moreira, "Correlação entre o pedido e a sentença", RePro 83, p. 210.

${ }^{359}$ Cf. Dinamarco, Instituições de direito processual civil, 2005, v. II, item 940. Em sentido similar, Guilhermo Jorge Enderle sustenta que o fundamento da congruência estaria nos princípios dispositivo e do contraditório, que deveria ser complementado com o princípio político, "que obliga a los jueces a resolver todas las cuestiones discutidas”. Cf. La congruencia procesal, 2007, p. 57

360 Assim a lição de Stefen Elias: "Essa dupla desnaturação do conflito (o necessário "corte" que a qualificação jurídica impõe e a inevitável distorção pela narrativa dos interessados) pode colocar ao julgador uma escolha que se revela fundamental: a solução do conflito se fara com respeito a sua natural complexidade ou, ao contrario, devera cingir-se aquelas alternativas possíveis diante das escolhas (pedidos) comunicadas pelos sujeitos envolvidos? A exigência de efetividade para o processo - o que significa que a solução deve, na máxima medida possível, abarcar todos os aspectos do conflito para que ele se extinga não apenas juridicamente - e a necessidade de que ele, processo, desenvolva-se de modo a garantir aos sujeitos certo grau de previsibilidade quanto ao conteúdo da decisão nele proferida, compõem um foco de tensão no processo civil brasileiro atual, que se encontrava satisfatoriamente resolvido pela regra da adstrição do julgador ao pedido do autor (ou das partes, em caso de ação dúplice), expresso no art. 293 do CPC. A tensão restou reavivada, sobretudo pelas alterações sofridas pelos arts. 461 e 807, e ainda pela entrada em vigor dos arts. 461-A e 475-N, I, todos do CPC". (Carlos Eduardo Stefen Elias, "As reformas processuais e o princípo da congruência entre sentença e pedido", RePro158, p. 41).

361 É por este motivo que afirma Nelson Nery: "A teologia do princípio da congruência não é outra senão proteção da vontade das partes. O autor fixa os limites da lide e da causa de pedir na inicial (CPC 128), cabendo ao juiz decidir de acordo com esse limite (CPC 460)". "Litispendência", Soluções práticas vol. 4, p. 261. 


\subsection{CORRELAÇÃO E ESTABILIZAÇÃO DO OBJETO LITIGIOSO DO PROCESSO}

O objeto litigioso do processo, definido pelas partes, pelo pedido mediato e pela causa de pedir ativa e remota (cf. Capítulo 3) deve ser uma constante no processo. O pedido, qualificado pelas partes e pela causa de pedir, não pode ser livremente alterado, sob pena de sérios prejuízos ao contraditório e ao andamento do processo.

Não basta seja exigida correspondência lógica entre demanda e tutela jurisdicional. Uma vez definida a matéria que deverá ser objeto da tutela jurisdicional, apta a afetar a esfera jurídica dos litigantes, e delimitado o objeto a respeito do qual as partes deverão se manifestar em contraditório, este não mais pode sofrer alterações. Fazê-lo significaria exigir do processo um eterno "voltar atrás" e impedir que prosseguisse para o julgamento de mérito e para o atendimento de seu escopo social.

Exatamente visando a este objetivo, a técnica processual concebe a "estabilização do objeto litigioso do processo". Cuidamos aqui de norma que estipula preclusão temporal, medida - não pelo tempo - mas em fases. Há, no Código de Processo Civil, duas referências concretas para tanto $(i)$ a citação do réu; e (ii) o saneamento do processo. ${ }^{362}$

$\mathrm{O}$ autor tem a liberdade de alterar - da forma que bem entender - os limites do objeto litigioso do processo - por meio das chamadas emendas à petição inicial - até a data da citação. Neste momento, ainda não instaurado o contraditório, a alteração não traz nenhum comprometimento para os litigantes e não prejudica o exercício do contraditório, razão pela qual o Código dá às partes amplos poderes de alteração.

Ocorre que, depois de citado o réu, e já tendo se estabelecido referência objetiva da demanda e do contraditório, a emenda implicaria necessidade de retrocesso com, no mínimo, o imperativo de renovação do prazo para a defesa e da oportunidade para que o réu se manifestasse novamente, agora considerando elementos novos, incluídos ou alterados no processo. "Feita a citação, é defeso ao autor modificar o pedido ou a causa de pedir, sem o consentimento do réu, mantendo-se as mesmas partes, salvo as substituições permitidas por lei" (CPC, art. 264).

\footnotetext{
362 Conforme leciona Fernando Rubin:“'a estabilização do processo, mediante a inalteração da causa de pedir e pedido, possui duplo fundamento: um particular, com efeitos privados, consiste na realização prática do princípio da lealdade processual, o que não consiste apenas na fidelidade à verdade, mas compreende a colocação clara e precisa dos fatos e dos fundamentos jurídicos por ambas as partes, de modo a não se surpreender, nem um nem outro, com alegações novas de fatos ou indicação de provas imprevistas. O outro fundamento da estabilização do processo é o do interesse público na boa administração da justiça, que deve responder de maneira certa e definitiva à provocação consistente no pedido do autor". (A preclusão na dinâmica do processo civil, p. 216).
} 
Há, neste segundo caso, certo prejuízo para o réu, que terá o trabalho de se defender pela segunda vez numa mesma relação jurídica processual. Por este motivo, a emenda da petição inicial (com alteração do objeto litigioso do processo), caso realizada após a data da citação, exige o consentimento deste.

Encontrando-se o processo de conhecimento (recitus fase cognitiva) ainda no seu primeiro momento (fase postulatória), o sistema entende que a ampliação/alteração do objeto litigioso do processo é tema que está relacionado, predominantemente, à esfera jurídica das partes, permitindo que estas, de acordo com sua vontade, aceitem ou não aceitem alterações no pedido, na causa de pedir e nas partes. Ocorre que, finalizada a fase postulatória, e estando o processo pronto para a instrução, o sistema passa a considerar este retrocesso prejudicial aos “interesses” da Jurisdição (norma de interesse público). ${ }^{363}$

A lei processual entende por inoportuno retrocesso neste momento já adiantado do desenvolvimento da relação jurídica processual, proibindo - mesmo mediante acordo de ambas as partes - a alteração do objeto litigioso do processo: "A alteração do pedido ou da causa de pedir em nenhuma hipótese será permitida após o saneamento do processo" (CPC, art. 264, parágrafo único).

A estabilização da demanda, portanto, é formada por diferentes preclusões processuais que tornam, ao desenvolver da relação processual, cada vez mais difícil a alteração do objeto litigioso do processo, até torná-la proibida, sempre visando a garantir o andamento regular do processo e o respeito ao princípio do contraditório.

\subsection{DEMANDAS ULTERIORES E ALTERAÇÃO DO OBJETO LITIGIOSO DO PROCESSO}

A estabilização do objeto litigioso do processo, como visto, encontra sua razão de ser no sistema processual e como toda norma preclusiva está relacionada com a garantia de que o processo "caminhe para frente", evitando retrocessos. Ocorre que esta comporta exceções.

A lei prevê - conforme já mencionado no Capítulo 5 - a possibilidade de o objeto litigioso do processo ser alterado, mesmo depois da citação e sem anuência do réu, por meio das chamadas demandas ulteriores. Estas podem partir da iniciativa das próprias

363 A respeito da definição do interesse público no processo civil, cf. Aprigliano, Ordem pública e processo, p. 66 e ss. 
partes (demandas ulteriores); do autor com a chamada "ação declaratória incidental", do réu com a "reconvenção" e "denunciação da lide" e, ainda, de terceiros, como ocorre nas hipóteses de "oposição" e de "intervenção litisconsorcial".364

Todos os casos cuidam de exceções legais, previstas expressamente pela lei processual, pelas quais outras demandas formuladas acabam por ampliar o objeto do processo, permitindo que novos pedidos ou causas de pedir sejam formuladas no curso do processo, de modo a admitir que a Jurisdição passe a conhecer de uma parcela mais ampla da situação conflituosa e, desse modo, atendendo ao escopo social do processo (ampliação do potencial de pacificação).

Com as demandas ulteriores, verificamos alteração no modelo original da congruência. A tutela jurisdicional passa a ter como referência, não apenas o conteúdo da demanda original, mas o conteúdo desta somado ao conteúdo dos demais pedidos formuladas no curso do processo. Daí um processo com conteúdo complexo, produto da soma das demandas formuladas, deve acarretar uma tutela jurisdicional igualmente complexa.

\subsection{EXCEÇÕES LEGAIS À CONGRUÊNCIA}

Ao tratarmos da interpretação do pedido (Capítulo 4) e da identificação das demandas (Capítulo 5) pudemos investigar que a congruência entre demanda e tutela jurisdicional é uma questão de direito positivo, de opção legislativa. Esta é a lição de Barbosa Moreira: “O princípio da congruência ou da correlação entre sentença e pedido não é, como quase nenhum princípio nesta matéria, absoluto; comporta diversas exceções, que precisam estar previstas na lei”. 365

Isto ocorre, fundamentalmente, porque o princípio da inércia comporta relativização e porque o contraditório pode ser resguardado, ainda nos casos em que o juiz está autorizado a atuar ex officio; ciente de que o juiz pode conceder bens da vida não

\footnotetext{
${ }^{364}$ Ao lado das demandas ulteriores, expressamente previstas pela lei, Bruno Silveira de Oliveira defende a formação de um processo com cúmulo de demandas, ainda que extrapolados os limites preclusivos da estabilização, no caso de reunião de demandas conexas. $\mathrm{O}$ efeito da reunião de demanda conexas é a formação de um processo único, de modo que a correlação - de uma única sentença e tutela para as demandas reunidas - deve observar o somatório das pretensões. (Cf. Conexidade e efetividade processual, $\mathrm{p}$. 313 e ss.).

${ }^{365}$ Barbosa Moreira, “Correlação entre o pedido e a sentença”, RePro 83, p. 212.
} 
demandados pelas partes, ante a autorização legal expressa, o demandado passa a receber informações suficientes (diretamente da lei) para que possa, se desejar, reagir adequadamente.

Porque está previsto na lei, o demandado sabe que determinado bem da vida, não pedido pelo demandante, pode lhe ser conferido e que, por este motivo, tem o ônus de reagir para tentar influenciar no conteúdo do futuro ato estatal. Esta informação prévia só existe quando (i) há claramente uma demanda; ou (ii) há uma previsão legal expressa.

O ordenamento jurídico prevê, desse modo, diversas exceções à regra da congruência, autorizando a iniciativa do juiz, ao instaurar o processo ou ao proferir sentença mais ampla do que aquela pleiteada pelas partes, seja por meio de demanda inicial ou ulterior.

Há processos que podem ser iniciados pelo juiz, como determina o artigo 989 do Código de Processo Civil: “o juiz determinará, de ofício, que se inicie o inventário, se nenhuma das pessoas mencionadas nos artigos antecedentes o requerer no prazo legal". Além disso, no que a doutrina erradamente optou por chamar de "pedidos implícitos", a lei autoriza o juiz a impor condenações ao pagamento de quantias sem nenhuma demanda, quando trata das verbas sucumbenciais: “A sentença condenará o vencido a pagar ao vencedor as despesas que antecipou e os honorários advocatícios” (CPC, art. 20).

Do mesmo modo são reguladas as penalidades decorrentes dos deveres de probidade e boa-fé processual: “O juiz ou tribunal, de ofício ou a requerimento, condenará o litigante de má-fé a pagar multa não excedente a um por cento sobre o valor da causa e a indenizar a parte contrária dos prejuízos que esta sofreu, mais os honorários advocatícios e todas as despesas que efetuou" (CPC, art. 18).

Outro exemplo relevante se encontra na lei que trata da "investigação de paternidade" de filhos havidos fora do casamento, pela qual há menção expressa de que, em sede de demanda com mero pedido declaratório de paternidade, está o juiz autorizado a condenar o pai ao pagamento de alimentos, independentemente de pedido: "Sempre que na sentença de primeiro grau se reconhecer a paternidade, nela se fixarão os alimentos provisionais ou definitivos do reconhecido que deles necessite" (Lei 8560/92, art. $7^{\circ}$ ). ${ }^{366}$

Ademais, como vimos no Capítulo 5, procedimentos especiais (tutelas diferenciadas) admitem a relativização da inércia, com o objetivo de pacificar com maior

\footnotetext{
366 Assim declara a jurisprudência: "A sentença de procedência da ação de investigação de paternidade pode condenar o réu em alimentos provisionais ou definitivos, independentemente de pedido expresso na inicial. Art. $7^{\circ}$ da Lei 8.560, de 29.12.92" (cf. STJ, 4 ${ }^{\mathrm{a}}$ T., REsp 257.885/RS, Rel. Min. Ruy Rosado de Aguiar, j. 21.09.2000, DJ 06.11.2000, p. 208).
} 
abrangência a relação litigiosa. Analisamos aqui esta possibilidade nos procedimentos da (i) ação de consignação em pagamento (CPC, arts. 896-899); (ii) ação de prestação de contas (CPC, arts. 916-918); (iii) ação revisional de locação (Lei de Locações, art. 68, IV); (iv) ação renovatória de locação (Lei de Locações, art. 72); (v) usucapião especial (Lei $6.969 / 81$, art. $\left.7^{\circ}\right)$; e (vi) ação de demarcação de terras. ${ }^{367}$

Em síntese, observamos que a congruência no processo civil funciona de dois modos distintos. A regra geral exige demanda para que a tutela jurisdicional seja concedida, nos seus estritos limites; demanda inicial ou mesmo a inicial somada a ulteriores. A exceção está em previsões legais, que autorizam em casos específicos que a tutela jurisdicional (bem da vida) seja concedida independentemente de demanda.

Dito isto, passaremos a investigar a seguir se outras hipóteses, previstas pela lei e ainda não tratadas nesta tese, que também representam hipóteses de modificação oficiosa do objeto litigioso do processo.

\subsection{ALTERAÇÃO LEGAL DO OBJETO LITIGIOSO: RESULTADO PRÁTICO EQUIVALENTE}

O Código de Processo Civil, reformado em 1994, trouxe regra especialmente concebida para a fase executiva do processo, determinando em seu artigo 461 que "na ação que tenha por objeto o cumprimento de obrigação de fazer ou não fazer, o juiz concederá a tutela específica da obrigação ou, se procedente o pedido, determinará providências que assegurem o resultado prático equivalente ao do adimplemento". 368

Notamos clara inspiração no artigo 84 do Código de Defesa do Consumidor, privilegiando a tutela específica nas obrigações de fazer ou não fazer sobre as tutelas genéricas, definidas como aquelas que visam ao pagamento de quantia em dinheiro, mediante atos de expropriação. ${ }^{369}$

\footnotetext{
${ }^{367}$ Estas hipóteses, conforme verificamos no Capítulo 4, não se confundem com os casos tratados pela jurisprudência como "pedidos implícitos", mas que, na verdade, cuidam de interpretações do pedido efetivamente formulado. Também não se confundem com os casos em que a técnica processual diferenciada autoriza a formulação de demandas informais (pedidos contrapostos) que ampliam o objeto litigioso do processo. Aqui não há de se falar em relativização da inércia, pois somente com a demanda ulterior (embora informal) pode o juiz ir além do que incialmente demandado.

${ }^{368}$ Cf. Bueno, Curso sistematizado de direito processual civil, vol. 3, $6^{\text {a }}$ ed., pp. 397-398.

${ }^{369}$ A respeito da definição de tutela específica e tutela genérica, cf. Talamini, Tutela relativa aos deveres de fazer e não fazer, p. 230.
} 
A norma tem como finalidade "a maior coincidência possível entre o resultado da tutela jurisdicional pedida e o cumprimento da obrigação caso não houvesse ocorrido lesão ou, quando menos, ameaça de direito no plano material". ${ }^{370}$ Podemos dizer que a reforma, ao estipular este dispositivo, objetivou que o "processo proporcione a quem tem direito tudo aquilo e somente aquilo que o jurisdicionado tem o direito de obter". 371

Nestes casos, o artigo 461 do Código de Processo Civil permite que o Estado-juiz adote medidas tendentes, não ao cumprimento da tutela específica correspondente ao objeto do processo, mas a tutela equivalente, "a fim de se alcançar o mesmo resultado (ou o mais próximo) que se teria com o cumprimento voluntário". ${ }^{372}$ Nesse sentido, Talamini elenca os seguintes exemplos de aplicação desta norma:

\footnotetext{
“a realização por terceiro de tarefa fungível que o réu se obrigara a fazer; o desfazimento por terceiro de obra que não poderia ter sido feita; o lacre de equipamento poluente, diante da inércia do réu em instalar filtros; a intervenção de auxiliar do juízo na administração de empresa, a fimm de adotar procedimentos e condutas (ativas ou omissivas) que vinham sendo descumpridas". ${ }^{373}$
}

O Código de Processo Civil parte do pressuposto de que o processo deve dar, a quem tem razão, exatamente aquilo que inicialmente pretendeu, sua chamada tutela específica, de modo que a tutela genérica (normalmente ressarcitória) seria algo desfavorável ao escopo jurídico do processo. Assim, permite que, mesmo nos casos em que a tutela especifica inicialmente desejada se mostre inviável, a Jurisdição evite o mero ressarcimento $\left(\mathrm{CPC}\right.$, art. 461, $\left.\S 1^{\circ}\right)$, concebendo meios alternativos para a satisfação do credor.

O resultado prático equivalente, desse modo, seria uma transformação da realidade equivalente àquela que a tutela específica originária teria o condão de perfazer (bem da vida) e que se produziria nas hipóteses em que esta se tornaria inviável. Melhor seria dar transformação distinta, mas equivalente à inicialmente desejada, do que remeter as partes ao mero ressarcimento dos prejuízos, especialmente quando esta tutela distinta tem potencial de trazer satisfação ao credor.

${ }^{370}$ Cf. Bueno, Curso sistematizado de direito processual civil, vol. 3, $6^{\text {a }}$ ed., pp. 397-398.

371 Cf. Dinamarco, A reforma do código de processo civil, p. 149 e ss; e Marcelo Abelha Rodrigues, Manual de Execução Civil, $3^{\mathrm{a}}$ ed., p. 224.

${ }^{372}$ Cf. Talamini, Tutela relativa aos deveres de fazer e de não fazer..., pp. 288-289.

${ }^{373}$ Cf. Talamini, Tutela relativa aos deveres de fazer e de não fazer..., p. 291. 
O credor se dá satisfeito, não porque a realidade se altera como ele desejou inicialmente, mas porque outra alteração ocorre e, embora diferente, também tem aptidão para atender aos seus interesses manifestados (na demanda ou no curso do processo).

Estabelecida a razão de ser da norma do artigo 461 do Código de Processo Civil, passaremos a verificar se esta autoriza, ou não, mudança no objeto litigioso do processo e, mais ainda, se cuida de uma norma aplicável apenas à fase de cumprimento de sentença ou se o juiz estaria autorizado a proferir sentença - na fase cognitiva do processo - já condenando o devedor a prestar o "resultado prático equivalente".

\subsection{RESULTADO PRÁTICO EQUIVALENTE: PEDIDO MEDIATO E PEDIDO IMEDIATO}

A noção tradicional de "resultado prático equivalente" está ligada ao direito das obrigações. A falta de cooperação do devedor permite que o Estado produza, não exatamente os efeitos desejados pelo credor com o cumprimento da obrigação, mas resultados que, do ponto de vista da transformação da realidade, seriam equivalentes. $\mathrm{O} \S$ $5^{\circ}$ do artigo 461 do Código de Processo Civil ressalta que:

“para a (...) obtenção do resultado prático equivalente, poderá o juiz, de ofício ou a requerimento, determinar as medidas necessárias, tais como a imposição de multa por tempo de atraso, busca e apreensão, remoção de pessoas e coisas, desfazimento de obras e impedimento de atividade nociva, se necessário com requisição de força policial".

A partir desta ideia, a doutrina tende a afirmar que a concessão do resultado prático equivalente configuraria "variação da forma de obtenção (jurisdicional) daquilo que deveria decorrer do adimplemento da obrigação por ato do próprio réu". Isto é, representaria simplesmente a mudança do "caminho executivo" inicialmente escolhido pela parte (em seu pedido imediato) para obter a tutela jurisdicional, mas não uma mudança no bem da vida almejado (pedido mediato). Assim a lição de Scarpinella Bueno:

“É correto, desta perspectiva de análise, o entendimento de que a diferença entre a tutela específica e o resultado prático equivalente ao do adimplemento repousa nas técnicas a serem empregadas jurisdicionalmente - na atividade jurisdicional executiva a ser desempenhada, portanto - para a 
obtenção do cumprimento da obrigação (pedido imediato), isto é, para perseguimento do bem da vida pretendido pelo autor (pedido mediato). ${ }^{374}$

Talamini segue a mesma linha, defendendo que a obtenção de resultado prático equivalente configuraria apenas a possibilidade de o juiz não respeitar o pedido imediato, respeitando, no entanto, o pedido mediato. ${ }^{375}$ A tutela específica e o resultado prático equivalente deveriam ser enxergados como dois lados de uma mesma moeda, o primeiro seria concedido quando o bem da vida almejado fosse atendido pela conduta do devedor (cooperação), enquanto que o segundo resultado - de mesma "natureza" - seria atendido por suposta conduta de terceiro ou por outra conduta equivalente. E complementa:

\begin{abstract}
“O pedido, nesse caso, é um só: o de obtenção do resultado específico. O acolhimento desse pleito autoriza automaticamente o emprego tanto de vias sub-rogatórias como coercitivas. As eficácias mandamental e executiva lato sensu estão ínsitas, com força prevalente, no comando que reconhece o direito do autor. (...) Para que se dê ao autor precisamente aquilo a que ele tem direito, confere-se ao juiz a função de adotar todas as medidas necessárias e conjugar as eficácias mandamental e executiva latu sensu, independentemente do pedido imediato do autor. Portanto, a eliminação do princípio da congruência entre pedido imediato e provimento que concede a tutela, no campo do art. 461, tem em mira o aperfeiçoamento da incidência desse mesmo princípio relativamente ao pedido mediato. A congruência formal cede espaço à congruência material”. 376
\end{abstract}

Não concordamos com as afirmações acima transcritas. Talvez o problema destas não esteja exatamente nas suas conclusões, mas na noção equívoca a respeito do que significa "bem da vida" ou "bene giuridico" ou "pedido mediato", problema que, como vimos, nasce com o desenvolvimento do conceito pelo próprio Chiovenda (item 2.10).

${ }^{374}$ Cf. Bueno, Curso sistematizado de direito processual civil, vol. 3, 6 a ed., pp. 397-398.

${ }^{375}$ No mesmo sentido ainda, cf. Marcelo Abelha Rodrigues, Manual de Execução Civil, $3^{\text {a }}$ ed., pp. 23023; Bianca Neves Amigo, "A natureza jurídica do resultado prático equivalente”, RePro152, pp. 361-362; e Araken de Assis, Cumprimento de sentença, $3^{\mathrm{a}}$ ed., p. 173. Sergio Bermudes também parece seguir a mesma linha, ao afirmar que "há uma diferença entre a tutela específica, cuja concessão depende de pedido, e o modo de sua efetivação, que o juiz pode estabelecer conforme o seu prudente arbítrio". (Cf. A reforma do código de processo civil, p. 67).

Marinoni, em sentido contrário, firma que a norma do artigo 461 do Código de Processo Civil autoriza a relativização da congruência entre pedidos mediatos e imediatos. "Ora, a possibilidade de imposição de atuação diversa da solicitada não se confunde com a possibilidade de imposição do pretendido através da utilização de um meio 'executivo' diferente do postulado. Isto ocorreria, observando-se ainda o exemplo acima narrado, se o autor houvesse requerido a instalação do filtro sob pena de multa, e o juiz, considerando as circunstâncias do caso concreto, determinasse que um terceiro o instalasse". E complementa afirmando que, no caso, "o juiz pode deixar de lado, além do meio executivo solicitado, o próprio pedido mediato, ou melhor, a providência (e não apenas o procedimento ou o meio executivo) que foi pedida". (Cf. Tutela inibitória:individual e coletiva, 2006, p. 158).

${ }^{376}$ Cf. Talamini, Tutela relativa aos deveres de fazer e de não fazer..., p. 404. 
Pedido imediato diz respeito à escolha da parte quanto à técnica processual, e depende fundamentalmente da escolha prévia e mais importante feita quanto ao direito material, quanto ao bem da vida desejado (pedido mediato). Há variação do pedido imediato quando a parte pede tutela declaratória e o juiz, identificando o erro da parte, concede tutela condenatória, pois o pedido mediato foi formulado para exigir uma prestação do devedor.

Podemos dizer, ainda, que pode haver simples alteração do pedido imediato quando a parte pede seja seguido o procedimento comum sumário e o juiz, identificando a ausência de um dos requisitos do artigo 275 do Código de Processo Civil, intima a parte para formular novo pedido, no sentido de que seja seguido o procedimento comum ordinário.

Não podemos, todavia, falar que, e.g. se a parte pede a instalação de filtro para evitar a poluição e o juiz, identificando a inadequação desta medida, determina o lacre de determinada máquina, para produzir o "resultado prático equivalente", estaríamos falando de uma variação de mero pedido imediato. Do mesmo modo, se o pedido é formulado no sentido de condenar o devedor a construir um muro e este, negando-se a cooperar, permite que o juiz determine que o muro seja construído por terceiro, às custas do devedor, não estamos falando de uma "mera alteração da escolha da técnica processual”. Pelo contrário, estamos falando em alteração da natureza da prestação devida: primeiro construir muro, depois pagar as despesas da construção por terceiro. ${ }^{377}$

A técnica do resultado prático equivalente confere ao juiz a possibilidade de transformar uma obrigação de fazer em uma obrigação de pagar quantia ou uma obrigação de não fazer ou de fazer em outra obrigação de fazer, entre outros casos. Por isso, não estamos falando da possibilidade de o Estado simplesmente não respeitar os meios executivos escolhidos pelas partes, mas em algo mais significativo, da possibilidade de concessão de um bem da vida distinto do pleiteado (pedido mediato).

A tese que fala na simples alteração do pedido imediato, com o fim de se obter a satisfação - mais ampla - do pedido mediato, da vontade substancial, parece partir de pressupostos equivocados para a definição destas categorias jurídicas (pedido imediato e

\footnotetext{
${ }^{377}$ Esta situação traz reflexos interessantes. A determinação de cumprimento da tutela específica por meio de conduta de terceiro, ao contrário do que é ressaltado pela doutrina que valoriza o artigo 461 do Código de Processo Civil, cuida de mera conversão da tutela específica originária em tutela ressarcitória. Isto porque, do ponto de vista da ordem emitida contra o devedor, há inicialmente uma condenação em fazer ou não fazer (ou mesmo entregar coisa) e, depois de cumprida a prestação de terceiro, esta tutela específica se converte, contra o mesmo devedor, em uma tutela meramente condenatória ao pagamento de quantia, i.e. despesas com o cumprimento da obrigação por parte do terceiro.
} 
mediato). Conforme demonstramos no item 3.4, o pedido mediato é representado pelo bem da vida (transformação social favorável) pretendido pelo demandante (a partir da subsunção dos fatos à norma aplicável), e não por um objetivo transcendental a ser intuído a partir da manifestação de vontade.

Esta interpretação "alternativa" não seria possível, pois o direito processual (constitucional e infraconstitucional) cuida de estipular parâmetros objetivos para tanto, quais sejam; o pedido deve ser interpretado a partir da $(i)$ a inércia, tentando aferir com precisão a vontade da parte; e do (ii) o contraditório e a ampla defesa, tentando eliminar dubiedades e respeitando legítimas expectativas surgidas nos sujeitos processuais a respeito do conteúdo da demanda. ${ }^{378}$

Em todos estes casos há preocupação extrema com a previsibilidade e com a segurança jurídica: não se admite uma análise metafísica do pedido, no sentido de extrair o "verdadeiro espírito da vontade da parte". Nada disso seria viável à luz das garantias constitucionais aplicáveis.

A demanda é representada pela vontade da parte no sentido de que uma determinada alteração da realidade seja obtida em relação às partes (mudanças sociais que o direito prevê). Por estas razões, tratando aqui da possibilidade de concessão de “transformações distintas" daquelas originariamente demandadas, não há como negar que a regra do artigo 461 do Código de Processo Civil configura verdadeira autorização legal para mudança do objeto litigioso do processo.

Estamos aqui tratando de clara colisão entre o princípio da inércia e da estabilização da demanda e a exigência de efetividade do processo. O Código de Processo Civil, em determinados casos concretos, entende que a necessidade de atender às especificidades das cambiantes relações de direito material justifica o rompimento da norma da congruência. Quando formulado, o pedido normalmente se pauta nas informações que o demandante possui na data do ajuizamento da demanda. Com o desenvolvimento do contraditório, as especificidades das relações de direito material podem se mostrar distintas e outra tutela, embora diferente da pleiteada, pode se mostrar mais adequada aos escopos jurídico e social do processo.

Ignorar estas circunstâncias e exigir do juiz a referência inflexível aos elementos originais da demanda poderia significar resultado inadequado, seja porque não adaptado à relação de direito material (escopo jurídico), seja porque ineficaz para a pacificação do

378 A respeito desta concepção mais elástica de bem da vida, cf. Bueno, Curso sistematizado de direito processual civil, vol. 3, $6^{\text {a }}$ ed., p. 399. 
conflito e para a satisfação dos interesses da parte (escopo social). Concordamos, por isso, com Talamini quando afirma que a razão de ser da norma do artigo 461 não está no interesse público ou na amplitude dos interesses representados pela relação de direito material, mas na "racionalização e operatividade" do processo. ${ }^{379}$

Este pensamento pode ser fundamentado a partir da ponderação de princípios como método para um processo de resultados, tal como concebida por Samuel Meira Brasil. O processualista defende não ser raro ocorrer o conflito entre o direito processual e o direito substancial e que, em tais casos, "o juiz deve ponderar qual norma deve prevalecer. Não se trata de 'revogação' ou 'invalidação' da norma processual ou da substancial. Trata-se de negar eficácia a uma norma (seja regra ou princípio), para assegurar uma maior utilidade na tutela jurisdicional a quem efetivamente tiver $\mathrm{o}$ direito". ${ }^{380}$ E completa:

\footnotetext{
“deve haver uma correspondência da certeza previsível do direito com o conteúdo material do princípio da segurança jurídica. A previsibilidade é a do homem médio, inserido culturalmente na sociedade. Um julgamento deve ser previsível, na medida em que o homem médico seja capaz de aceitar o seu resultado. Uma decisão judicial legal, mas manifestação injusta, não é 'previsível' para a sociedade, que espera uma solução diversa, uma solução correta e justa". ${ }^{381}$
}

Nesse sentido, a ponderação de princípios - feita previamente pelo legislador permite que, neste caso específico do artigo 461 do Código de Processo Civil, a previsibilidade quanto ao resultado do processo (que se limitaria ao acolhimento ou à rejeição do pedido formulado) seja conformada com a necessidade de o sistema processual conceder decisões mais justas e tendentes à pacificação da crise de direito material.

\subsection{RESULTADO PRÁTICO EQUIVALENTE: LIMITES}

Até o momento, ficou assentada a premissa de que a relativização imposta pela regra do artigo 461 do Código de Processo Civil, como as demais hipóteses tratadas de

\footnotetext{
${ }^{379}$ Cf. Talamini, Tutela relativa aos deveres de fazer e de não fazer..., p. 404.

${ }^{380}$ Cf. Samuel Meira Brasil, Justiça, direito e processo, p. 111.

${ }^{381}$ Cf. Samuel Meira Brasil, Justiça, direito e processo, p. 116.
} 
exceções legais à congruência, tem o objetivo de atender à exigência de efetividade do processo. Sua aplicação, no entanto, deve respeitar certos limites.

O primeiro destes limites está no contraditório. A estabilização da demanda e a necessidade de correlação entre demanda e tutela jurisdicional estão intimamente ligadas ao imperativo de o processo ter um resultado previsível: ou o pedido será acolhido ou será rejeitado (parcial ou integralmente). Nenhuma outra solução seria possível.

Contando com esta informação, o demandado toma suas decisões, adota suas estratégias, opta por se defender ou não, ou mesmo opta por contra-atacar. Este é o motivo pelo qual o sistema processual não admite - de um modo geral - alterações neste paradigma, fazê-lo significaria trazer grande surpresa às partes e atrapalhar toda a dinâmica do debate processual.

Por tais razões, quando excepcionalmente a lei permite a relativização da congruência por conduta do juiz (assim como ocorre no resultado prático equivalente), é fundamental seja renovada a oportunidade de participação das partes. Cabe ao juiz dar um passo atrás no processo e chamar as partes para exercerem o contraditório a respeito do novo bem da vida que se pretende conceder, avaliando sua admissibilidade e adequação ao caso concreto.

Nesse sentido, Marinoni tratando do artigo 461 do Código de Processo Civil, leciona que o contraditório não deve se limitar, apenas, à discussão a respeito da lesão ou ameaça de lesão a direito, tendo como referência os requisitos do pedido originário, mas também dever garantir "que o contraditório tenha permitido a conclusão a respeito do meio mais idôneo para a tutela do direito. Em outras palavras, o juiz não pode, sem conferir oportunidade de discussão às partes, conceder meio diverso do pedido". 382

A exigência de se franquear participação às partes está relacionada com a visão do contraditório sob a sua perspectiva da cooperação. ${ }^{383}$ É fundamental que o juiz mantenha conduta previsível para com os demais sujeitos do processo, não furtando suas legitimas expectativas em relação ao procedimento e ao resultado de sua atividade. ${ }^{384}$ Assim salienta Sérgio Cruz Arenhart:

382 Cf. Marinoni, Tutela específica, $3^{\mathrm{a}}$ ed., p. 98. No mesmo sentido, cf. Gajardoni, Flexibilidade procedimental, p. 178.

${ }^{383}$ Cf. Edoardo F. Ricci, "Princípio do contraditório e questões...”, Processo e Constituição, p. 496 e ss.

384 Assim é a lição de Barbosa Moreira, para quem a garantia do contraditório "implique pour le juge l'intediction de prendre des mesures sans en avertir les parties et d'appuyer sés décisions sur des faits et des résultats de l'instruction au sujet desquels elles n'auraient pu s'exprimer". ("Le noveau Code de Procedure Civile vu par un juriste brésilien", Temas...: Quinta Série, p. 42). Do mesmo modo, analisando a jurisprudência da Corte da Cassação italiana, Giuseppe Tarzia identifica a existência de um poder-dever do juiz e de seus auxiliares de informar as partes a respeito dos poderes processuais a elas conferidos pela lei, e 
"este papel, atribuído ao magistrado, de orientar e advertir as partes não constitui novidade em nosso ordenamento jurídico. Com efeito, ele já existe na orientação dos efeitos da revelia - que acompanham a comunicação do réu para se defender - ou na admoestação quanto aos efeitos decorrentes do não-comparecimento para prestar o depoimento da parte (art. 343, §1 ${ }^{\circ}$, do CPC), ou ainda o aviso judicial sobre possível modificação do regime do ônus da prova (art. $6^{\circ}$, VIII, do CDC)". 385

Para evitar surpresas, e uma vez identificada a possiblidade de concessão de "resultado prático equivalente", o juiz deve chamar as partes para se manifestarem a respeito desta possibilidade, instaurando - ainda que ultrapassada a fase postulatória - um novo incidente cognitivo no processo. ${ }^{386}$ Esta participação, com efeito, deve ocorrer a partir da ideia de "contraditório útil", concedendo-se não informação e oportunidade de participação, mas também efetivas condições de influenciar o juízo a ser formado a respeito da questão debatida. ${ }^{387}$

Esta é a tendência das legislações estrangeiras que - de uma forma geral proíbem o juiz de decidir a respeito de questões ex officio sem antes dar oportunidade de participação das partes. Nesse sentido determina o artigo $266^{\circ}$ do Código de Processo Civil Português, o § 139 da Zivilprozessordung (ZPO) Alemã, bem como o artigo 16 do Code de Procèdure Civile Francês. Na Itália, embora inexista previsão legal, a exigência é contemplada pela doutrina e pela jurisprudência. ${ }^{388}$

Em nosso sistema, não encontramos na lei ou na jurisprudência visíveis registros de que seja fundamental ao órgão julgador provocar tal manifestação, a doutrina, porém, já tem apontado nesse sentido, indicando os benefícios que podem ser trazidos por tal

aos prazos e modos para o seu exercício. ("Le instruzione del giudice alle parte...", Rivista di Diritto Processuale 4, 1981, p. 637 e ss).

${ }^{385}$ Após discorrer a respeito da relevância do princípio da informação nos ordenamentos processuais da antiga União Soviética, Giuseppe Tarzia, referindo-se à evolução do direito italiano e de outros países europeus ocidentais, aponta que "il dovere di informazione o instruzione del giudice nei confronti delle parti per ciò che concerne i loro diritto e obblighi processuali, e in particolare i poteri che ad essi sperrano e i mezzi per i loro esercizio, acquista nell'ambito de generale movimento verso la $<<$ socializzazione $>>$ del processo civile". (Tarzia, "Le instruzione del giudice...", Rivista di Diritto Processuale 4, 1981, p. 660).

${ }^{386}$ Cf. Edoardo F. Ricci, "Princípio do contraditório e questões...", Processo e Constituição, p. 496 e ss; Dinamarco, Instituições..., $2^{\mathrm{a}}$ ed., vol. 1, p. 224; e Teresa Arruda Alvim Wambier, Anotações sobre o princípio do contraditório..., p. 74.

${ }^{387}$ Cf. Gajardoni, Flexibilidade procedimental..., p. 110.

${ }^{388}$ Cf. Comoglio, "Contradittorio", Digesto delle discipline privatistiche, vol. IV, pp. 9-11. 
conduta do juiz, especialmente a partir de uma visão mais ampla do princípio do contraditório. ${ }^{389}$

Definida a necessidade de observância do contraditório, resta identificar o segundo limite para a concessão do resultado prático equivalente: i.e. a própria vontade da parte. Ainda que a norma importe na possibilidade de concessão ex officio de um bem da vida qualitativamente distinto do pleiteado pelas partes, esta exige que este bem da vida apresente - do ponto de vista da transformação social que tem aptidão de produzir - um "resultado prático equivalente".

Não há referência concreta ou objetiva do que seria isso. Tratamos de um conceito jurídico indeterminado que confere poderes decisórios ao juiz de amplitude incomum, especialmente se tomarmos como referência outras normas relativas ao ato de decidir (e.g. CPC, 459 e 460) e à interpretação do pedido (CPC, art. 283). Seria impossível exigir que o bem da vida que pretendemos obter como "resultado prático equivalente" decorra dos mesmos fatos alegados como causa de pedir para o pedido originariamente formulado.

Fatos essenciais podem variar significativamente caso a caso, basta pensar no exemplo do pedido de fechamento da fábrica. A causa de pedir estaria no fato de a fábrica ofender normas ambientais e emitir poluição ilicitamente, prevendo a lei a pena de fechamento. O resultado prático equivalente a este pedido, i.e. a instalação de filtros, por consequência, teria como premissa - pelo menos - parte dos fatos obrigatoriamente distintos, tais quais aqueles que demonstrariam e.g. (i) a eficácia do filtro em barrar os poluentes; e (ii) a possibilidade/viabilidade de instalação daquele equipamento. ${ }^{390}$

Tampouco é possível afirmar que, para que exista um "resultado prático equivalente" seria necessário se pautar na mesma causa de pedir jurídica. Embora no exemplo narrado tenhamos sempre que tratar de normas que cuidam do direito ambiental e do dever de não poluir ilicitamente, estaremos tratando de duas sanções legais distintas, previstas por normas distintas (regras ou princípios): uma norma hipotética que determinaria o fechamento da fábrica pela poluição e outra norma que exigiria da fábrica poluente a redução de suas emissões por meio da utilização de filtros.

\footnotetext{
389 Bueno, a despeito de afirmar que a concessão do resultado prático equivalente caracteriza alteração apenas do "pedido imediato", ressalta a necessidade de "prévia oitiva das partes (autor e réu)" para a aplicação da regra. (Cf. Bueno, Curso sistematizado de direito processual civil, vol. 3, 6a ed., p. 398). A respeito da necessidade de prévio contraditório a respeito da decisões de matérias cognoscíveis ex officio, Cf. Dinamarco, Instituições..., $2^{a}$ ed., vol. 1, p. 224; e Teresa Arruda Alvim Wambier, Anotações sobre o princípio do contraditório..., p. 74; e Aprigliano, Ordem pública e processo, p. 71.

390 Note-se que a existência de fatos essenciais distintos a justificarem a concessão de resultado prático equivalente é circunstância que ressalta a necessidade de respeito prévio e amplo ao contraditório.
} 
Efetivamente, o artigo 461 do Código de Processo Civil exige que o juiz identifique a razão de ser da pretensão da parte e julgue inadequado o pedido, seja porque desnecessariamente maléfico ao demandado (e.g. CPC, art. 620) seja porque pouco eficaz para o atendimento dos seus propósitos (inadequação frente às circunstâncias da relação de direto material). Feita esta análise, o juiz passa a conceber - livremente - dentro do ordenamento jurídico quais outros efeitos poderiam ser produzidos para aquela mesma relação jurídica conflituosa, escolhendo um destes efeitos - que julga equivalente - como novo "bem da vida" a ser conferido pelo processo.

Esta análise - mais uma vez - deve depender das circunstâncias da relação de direito material e das prescrições do direito aplicável ao caso. ${ }^{391}$ No entanto, o juiz deve estar certo de que não pode se valer deste expediente para "trair a vontade da parte", concedendo bem da vida que não mantém relação com os objetivos que se pode identificar no pedido originariamente formulado. ${ }^{392}$

Em síntese: não há como delimitar cartesianamente os limites para atuação do juiz ao conferir "resultado prático equivalente". A norma exige que o juiz tenha aptidão de identificar as transformações sociais - da realidade fática - que a parte deseja obter com aquele pedido especificamente formulado, tais como parar poluição, obter a construção de um muro, fazer cessar atos lesivos ao consumidor, reconstituir patrimônio, etc. e, a partir daí, conceber outros bens da vida que poderiam ser obtidos a partir dos fatos narrados na demanda (ou de outros fatos afins) e que teriam aptidão de ocasionar transformações equivalentes na realidade dos fatos.

\footnotetext{
${ }^{391}$ A jurisprudência do Superior Tribunal de Justiça confirma esta constatação ao declarar que: “(...) As medidas previstas no $\S 5^{\circ}$ do art. 461 do CPC foram antecedidas da expressão "tais como", o que denota o caráter não-exauriente da enumeração. Assim, o legislador deixou ao prudente arbítrio do magistrado a escolha das medidas que melhor se harmonizem às peculiaridades de cada caso concreto". (STJ, 2 ${ }^{\mathrm{a}}$ T., REsp 770.969/RS, Rel. Min. Castro Meira, DJ 03/10/2005).

392 Bianca Neves Amigo ressalta a importância de se levar em consideração as circunstâncias do caso concreto. Para tanto cita o exemplo de demanda que visa a condenar assistência técnica a efetuar o conserto de telefone celular. Não efetivada a conduta, questiona se seria resultado prático equivalente determinar-se a entrega de aparelho novo do mesmo modelo. A resposta deverá depender da hipótese. Caso a parte tenha informações relevantes salvas no aparelho estragado, decerto que a entrega de aparelho novo não representaria resultado prático equivalente. No entanto, caso estas informações fossem irrelevantes, seria possível responder positivamente. (Cf. "A natureza jurídica do resultado prático equivalente", RePro 152, pp. 365-367).
} 


\subsection{RESULTADO PRÁTICO EQUIVALENTE: APLICÁVEL À FASE COGNITIVA?}

A norma do artigo 461 se encontra ao lado dos dispositivos que cuidam do cumprimento de sentença, especificamente, do cumprimento das sentenças condenatórias que impõem obrigações de fazer e de não fazer.

Mais do que isso, a redação do dispositivo nos remete a um princípio que motivou a reforma do Código de Processo Civil, o privilégio da tutela específica sobre a genérica, em sede de cumprimento de sentença, mitigando-se a regra geral da conversão em perdas e danos a partir da inexequibilidade da tutela específica, até então vigente pelo artigo 633 do Código de Processo Civil: "Se, no prazo fixado, o devedor não satisfizer a obrigação, é lícito ao credor, nos próprios autos do processo, requerer que ela seja executada à custa do devedor, ou haver perdas e danos; caso em que ela se converte em indenização".

Dito isso, questionamos: o artigo 461 do Código de Processo Civil é norma que se aplica apenas em sede de cumprimento de sentença ou pode o juiz, já no curso da fase cognitiva, proferir sentença concedendo o "resultado prático equivalente" e, desse modo, alterando ex officio o objeto litigioso do processo?

Entendemos ser possível a utilização da regra, também, na fase cognitiva do processo. Em primeiro lugar, pois a doutrina e a jurisprudência entendem que a concessão do resultado prático equivalente não seria aplicável, apenas à fase de cumprimento de sentença, admitindo de forma pacifica sua utilização em sede de antecipação de tutela.

O fundamento desta possibilidade reside no disposto no $\S 3^{\circ}$ do artigo 461 o qual determina que "sendo relevante o fundamento da demanda e havendo justificado receio de ineficácia do provimento final, é lícito ao juiz conceder a tutela liminarmente ou mediante justificação prévia, citado o réu". Além disso, conforme leciona Talamini, "a exclusão prévia e em abstrato da concessão antecipada dessa tutela seria sistematicamente inexplicável diante da consagração daquilo que se poderia chamar 'poder geral de antecipação', no art. 273". 393

De fato, se a tutela é admitida de modo antecipado ou se seus efeitos podem ser integralmente antecipados com fundamento no artigo 273 do Código de Processo Civil, como seria possível pensar que esta mesma tutela não seria admissível definitivamente, como tutela de mérito?

${ }^{393}$ Cf. Talamini, Tutela relativa aos deveres de fazer e de não fazer, p. 293. 
Em segundo lugar, pois a amplitude do contraditório referente à fase de conhecimento é sede ainda mais adequada que o cumprimento de sentença, de modo que sejam avaliados os requisitos para a concessão do resultado prático equivalente; $(i)$ respeito prévio ao amplo contraditório; (ii) adequação da medida; (iii) coerência com a manifestação de vontade originariamente formulada.

As justificativas de "racionalização e operatividade" que motivam a existência da regra se mostram presentes tanto na fase cognitiva quanto na fase de cumprimento de sentença. O juiz pode identificar no curso da fase postulatória ou mesmo na fase de instrução que o bem da vida inicialmente pleiteado é inadequado para a pacificação social ou mesmo não se mostra proporcional, tendo em vista a imposição de menor onerosidade ao demandado (CPC, art. 668). ${ }^{394}$

A Jurisdição portanto, tem autonomia - desde que respeitado o contraditório e minimamente a vontade original da parte - de propor resultado equivalente ao bem da vida pleiteado, transformando o objeto litigioso do processo, de modo a dele fazer um instrumento mais efetivo. ${ }^{395}$

\subsection{OBRIGAÇÕES INFUNGÍVEIS E ART. 461 DO CPC}

Vimos e ressaltamos que a norma do artigo 461 do Código de Processo Civil está preocupada em fazer retratar no processo civil o privilégio da chamada "tutela específica" sobre a tutela genérica. Há uma ideia geral de que o melhor seria dar ao autor o que ele "exatamente quer", a isso se chama de "tutela específica", a original. Ocorre que, não

\footnotetext{
${ }^{394}$ Cf. Marinoni, Tutela inibitória:individual e coletiva, $4^{\mathrm{a}}$ ed., pp. 158-162.

395 A título de exemplo, podemos afirmar que a previsão legal de "fungibilidade" para as ações possessórias cuida, na verdade, de um caso concreto de aplicação do resultado prático equivalente, de modo que os artigos 926 e 932 simplesmente cuidam de uma das hipóteses específicas que, de um modo geral, representam a regra geral do artigo 461 do Código de Processo Civil. Em relação às possessórias, verificamse três situações fáticas modelo, que correspondem a três pedidos distintos de obrigação de fazer e de não fazer. Havendo turbação, a medida a ser deferida será a manutenção de posse, havendo esbulho, a medida será a reintegração de posse e, havendo justo receio de moléstia, a medida será o interdito proibitório (CPC, arts. 926 e 932). Nesse contexto, "fungibilidade" configura não indiferença entre meios disponíveis, como ocorre no direito material, mas possibilidade de conversão oficiosa, do pedido requerido naquele cujos requisitos fáticos restaram demonstrados no caso concreto. Acaso se trate de mero receio de moléstia, o interdito proibitório será concedido, ou se trate de turbação ou esbulho, será concedida a manutenção ou reintegração de posse, respectivamente, sem prejuízo da tutela inicialmente requerida pela parte. Isto porque, “a propositura de uma ação possessória em vez de outra não obstará a que o juiz conheça do pedido e outorgue proteção legal correspondente àquela, cujos requisitos estejam provados” (CPC, art. 920).
} 
sendo possível conceder esta "tutela específica original”, a segunda melhor opção seria dar resultado prático equivalente.

Neste caso, ainda estaríamos no âmbito da tutela específica em sentido lato, ao passo que, embora o processo não conceda ao demandante a exata transformação da realidade que ele desejava (bem da vida), os novos efeitos práticos (equivalentes) seriam aptos a provocar transformação similar no mundo dos fatos, satisfazendo de algum modo o demandante. Com base nesse sistema, a tutela ressarcitória decorrente da inexequibilidade (CPC, art. 461, $\S 1^{\circ}$ ) - esta sim uma tutela "não específica" ou "tutela genérica" - seria a última opção: o Estado-juiz a esta recorreria apenas em último caso, quando impossível a tutela específica originária e, também, impossível o "resultado prático equivalente" (tutela específica em sentido lato).

A questão que colocamos agora, no entanto, é: prevista no artigo 461 do Código de Processo Civil, a norma seria aplicável a todas as obrigações de fazer e não fazer, inclusive às infungíveis?

A doutrina de um modo geral trata desta possibilidade apenas nos casos das obrigações fungíveis, concebidas como aquelas que - por não exigirem características personalíssimas do devedor - podem ser adimplidas pela conduta de terceiros (CC, art. 249). Nesses casos, pelo fato de a prestação, quando fungível, poder ser facilmente trocada, substituída, por outra de mesma natureza, é mais fácil se conceber um resultado equivalente. ${ }^{396}$

Nas obrigações infungíveis não seria possível conceber a mesma facilidade, pois fracassadas as medidas coercitivas com o objetivo de dar a tutela originária, o não cumprimento da tutela específica deve gerar - via de regra - a impossibilidade de entrega do resultado inicialmente desejado pela parte, remetendo-a à tutela genérica, de natureza ressarcitória $\left(\mathrm{CPC}\right.$, art. $\left.461, \S 1^{\circ}\right)$. Se pelas suas características a prestação devida não poderia ser cumprida de outro modo, senão pela cooperação personalíssima do devedor, na falta desta não haveria outra saída senão converter a medida em perdas e danos.

Esta afirmação, no entanto, não pode ser tomada como absoluta. Isto ocorre, pois há hipóteses de obrigações infungíveis que admitem a produção de efeitos equivalentes por meio da conduta de terceiros ou mesmo por ato judicial. O melhor exemplo residiria nas obrigações de prestar declaração de vontade, às quais - descumpridas pelo devedor - são

\footnotetext{
${ }^{396}$ Cf. Orlando Gomes, Obrigações, $15^{\mathrm{a}}$ ed., p. 38; e Sílvio de Salvo Venosa, Direito Civil..., vol. II, $2^{\mathrm{a}}$ ed., p. 101.
} 
passíveis da produção de resultados equivalentes por um ato do juiz, de natureza constitutiva. $^{397}$

O curioso desse exemplo está no fato de que o resultado prático equivalente não está em outra obrigação ou prestação, mas em provimento jurisdicional de natureza constitutiva, que produzirá os efeitos equivalentes à manifestação de vontade da parte, nos termos do art. 466-A, 466-B e 466-C do Código de Processo Civil.

Ainda tratando das obrigações de fazer infungíveis, podemos pensar em casos nos quais, embora personalíssima a obrigação assumida, possa o próprio credor - depois de devidamente consultado - complementar sua vontade (supervenientemente) e manifestar renúncia a esta circunstância, admitindo que obrigação equivalente venha a ser cumprida por terceiro, à custa do devedor. Pensemos em organizador de concerto musical, credor de obrigação de fazer assumida por músico contrabaixista (obrigação personalíssima). Na recusa deste em cooperar, é razoável pensar na possibilidade de contratar outro músico para a mesma função, à custa do devedor, em hipótese clara de concessão de resultado prático equivalente.

Do mesmo modo, podemos pensar que, ainda que o pedido e a sentença digam respeito ao cumprimento de uma obrigação de não fazer, pode o juiz - na ausência de cooperação do devedor - evitar as perdas e danos, determinando a produção de resultado prático equivalente. Pensemos aqui na obrigação de não fazer da qual já tratamos muitas vezes acima: proibição de funcionamento de fábrica a fim de evitar poluição. Formulado pedido condenatório em obrigação de não fazer (fechamento da fábrica) visando a fazer cessar a poluição, pode o juiz conceder, como resultado prático equivalente, condenação em fazer algo, i.e. instalar filtro.

O próprio conteúdo aberto da norma processual do art. 461 do Código de Processo Civil, especialmente se interpretado à luz da garantia constitucional de efetividade do processo, deve figurar como instrumento amplo que, respeitadas as garantias aplicáveis (especialmente o contraditório), deve permitir que o processo produza, sempre que possível, os melhores resultados práticos, adaptando-se às circunstâncias de cada relação de direito material.

\footnotetext{
${ }^{397}$ Marcelo Abelha Rodrigues, nesse sentido, ressalta que o critério para a aplicabilidade do art. 461 do CPC seria deve estar na possibilidade de resultados práticos serem obtidos, independentemente da natureza da medida. Nesse sentido, cita o exemplo da obrigação de prestar declaração de vontade que, embora infungível, permite a produção de resultado prático equivalente conforme arts. 466-A, 466-B e 466-C do

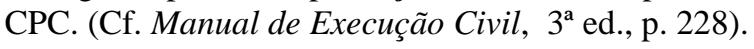


Especialmente nos casos das obrigações infungíveis, esta solução se mostra adequada a partir de uma visão ativa do juiz no contraditório (princípio da cooperação), chamando as partes para um diálogo e permitindo que sua manifestação de vontade se molde às vicissitudes das relações de direito material, de modo a permitir melhor atendimento do escopo jurídico e social do processo.

\subsection{OBRIGAÇÕES DE DAR E ART. 461 DO CPC}

Estabelecendo a amplitude da norma, surge adicional questionamento: embora a possibilidade de concessão de "resultado prático equivalente" seja tratada no artigo 461 do Código de Processo Civil, que cuida das obrigações de fazer e de não fazer, esta norma também poderia ser aplicável a outras espécies de execução?

Entendemos que sim. Nesse sentido, o Código de Processo Civil, nos termos do $\S$ $3^{\circ}$ do artigo 461-A, indica, com sua remissão ao artigo 461, que também nas obrigações de entregar coisa deve ser seguida a mesma lógica. Não sendo possível a entrega da coisa devida (tutela específica originária), deve o juiz - antes de remeter às partes à tutela ressarcitória - conceber a possibilidade de dar "resultado prático equivalente".

Esta possibilidade ocorre tanto para a entrega de bens fungíveis quanto para a entrega de bens infungíveis. No primeiro caso (bens fungíveis), pensemos na obrigação de entrega de sementes de trigo do tipo XX que se tornou impossível com o esgotamento da mercadoria no mercado. Não poderia o juiz, identificando este fato e previamente consultando as partes, determinar que o réu entregasse sementes XY de valor similar e de natureza similar às $\mathrm{XX}$, evitando a tutela ressarcitória? No segundo caso (bens infungíveis), tendo o processo por objeto a entrega de determinado apartamento e sendo este vendido a terceiros, não poderia o juiz exigir que a empresa incorporadora entregue ao comprador/credor (mediante sua prévia anuência) outro apartamento similar, de modo a evitar a tutela ressarcitória?

Parece-nos que, também nestas hipóteses, estaríamos a privilegiar que "processo proporcione a quem tem direito tudo aquilo e somente aquilo que o jurisdicionado tem o direito de obter", evitando a complexa e, muitas vezes, inefetiva tutela ressarcitória, que significa consumo maior de tempo para quem tem razão e, especialmente, maiores gastos do Estado com a manutenção do processo e de todos os incidentes a ele correlatos, quais 
sejam, liquidação, perícia e recursos, impugnação ao cumprimento de sentença, alienação judicial, possibilidade de nova impugnação e mais os recursos correlatos. ${ }^{398}$

\subsection{OBRIGAÇÕES DE PAGAR QUANTIA E ART. 461 DO CPC}

Assentada a premissa de que a regra do "resultado prático equivalente" deve ser aplicável, não apenas às obrigações de fazer e não fazer, mas também às obrigações de entrega de coisa, resta uma última questão: poderíamos pensar na aplicação desta regra às tutelas condenatórias ao pagamento de quantia em dinheiro?

O questionamento inicialmente parece esdrúxulo, na medida em que, por definição, a "tutela específica originária" aqui seria o ressarcimento de quantia em dinheiro, é dizer, os efeitos originariamente pretendidos pelo demandante seriam os relativos a uma tutela simplesmente ressarcitória.

Ocorre que, em muitos casos, e por circunstâncias das relações de direito material, mesmo quando formulado pedido condenatório em quantia em dinheiro, a determinação de medida equivalente (obrigação de fazer, não fazer ou de dar coisa) pode se mostrar mais adequada do ponto de vista do (i) escopo jurídico; e do (ii) escopo social do processo. Nesses casos, com base no artigo 461 do Código de Processo Civil, teria o juiz o poder de relativizar a congruência?

Entendemos que sim. Pensemos nos casos em que, existente obrigação de fazer ou de entregar coisa, esta - não visão do demandante - teria se tornado inexequível, fazendo serem aplicados os efeitos dos artigos 234 e 247 do Código Civil, que determinam sua conversão em perdas e danos. $\mathrm{O}$ autor, assim, propõe demanda condenatória ao pagamento de quantia em dinheiro correspondente ao valor das perdas e danos. Ocorre que, no curso do processo, o juiz identifica - por meio das provas - que a obrigação não se tornou inexequível (ao contrário do que originariamente pensava o autor), sendo ainda viável seu cumprimento in natura.

Nesse caso, notemos que nos termos do direito material, poderíamos dizer que, embora haja inadimplemento (a prestação específica não foi cumprida) e crédito (há a obrigação do devedor), este diria respeito à prestação não pleiteada (fazer ou entregar

\footnotetext{
${ }^{398}$ Cf. Marcelo Abelha Rodrigues, Manual de Execução Civil, $3^{\mathrm{a}}$ ed., p. 224.
} 
coisa), e não às perdas e danos correspondentes ao pedido formulado e às quais o autor não teria direito, pela não caracterização da inexequibilidade (CC, arts. 234 e 247).

Caso o juiz entenda pela impossibilidade de conceder "resultado prático equivalente", a única resposta possível seria o julgamento de improcedência do pedido, pela inexistência do direito de exigir perdas e danos. No entanto, esta medida seria desproporcional e irrazoável, e configuraria desperdício de atividade jurisdicional. Desenvolveríamos todo um processo, chegaríamos à conclusão de que o autor tem crédito em face ao devedor, com base na mesma relação de direito material, mas negaríamos o pedido pela interpretação de que - ao contrário do que o autor pensava - a obrigação originária ainda seria exigível, tornando inviáveis as perdas e danos.

Por este motivo, e estando neste exemplo presente a mesma necessidade de se atender ao escopo jurídico e social do processo, entendemos que, mesmo nos casos de pedido de tutela condenatória ao pagamento de quantia é possível pensar na aplicação dos efeitos do artigo 461 do Código de Processo Civil, convertendo esta em obrigação de fazer, não fazer, de entregar coisa ou mesmo em tutela constitutiva, nos casos de obrigações de prestar declaração de vontade.

\subsection{RESULTADO PRÁTICO EQUIVALENTE: IMPOSSIBILIDADE E INADEQUAÇÃO DA MEDIDA}

Como visto, o resultado prático equivalente é técnica processual que visa a evitar a tutela genérica, privilegiando uma resposta jurisdicional que, embora não correspondente ao pedido formulado, aproxima-se deste. Isto significa que, em primeiro lugar, desejamos a concessão do efeito demandado pela parte e, apenas em segundo lugar, para evitar a tutela ressarcitória, admitimos o resultado prático equivalente. É dizer, apenas quando impossível a concessão da tutela específica originária podemos conceder tutela específica alternativa.

O problema ao qual nos dirigimos agora é: a aplicação do dispositivo em análise se restringe aos casos tratados pelo próprio direito material como hipóteses de inexequibilidade, tal como determinam os artigos 234 e 247 do Código Civil?

Entendemos que não. A norma do artigo 461 deve ser interpretada, não apenas à luz da inexequibilidade da tutela originária, mas também à luz do princípio da menor onerosidade previsto pelo artigo 620 do Código de Processo Civil. Conforme Marinoni, a concessão do resultado prático equivalente deve observar os critérios da efetividade e da 
necessidade. "Isto quer dizer que o juiz não pode deixar de inibir o ilícito em virtude de o meio solicitado não se mostrar eficaz; mas também que ele não pode tutelar o direito através de um meio que possa causar prejuízo excessivo à esfera jurídica do réu". 399

A interpretação é reflexo da necessidade de o juiz buscar a melhor solução para a crise de direito material, adaptando, não apenas a técnica processual, mas o resultado do processo em consonância com as necessidades da crise de direito material. Dar esta flexibilidade para o juiz significa acentuar, não apenas o escopo jurídico do processo, mas também o escopo social.

Caso o juiz estivesse irremediavelmente limitado a conceder ou negar o efeito pleiteado pelo demandante (e não podendo este efeito ser decomponível em diferentes quantidades), entendendo que a medida solicitada pela parte é demasiadamente grave para a situação que a justificou, o juiz, ainda que identificasse a necessidade de intervenção jurisdicional, estaria obrigado a rejeitar a tutela e manter o estado de crise. No entanto, se ao juiz é concebida a possibilidade de dar tutela qualitativamente distinta, mas que represente grau de intervenção menor na esfera jurídica do réu, não apenas estará dando o resultado mais justo (do ponto de vista do direito material) como terá condições de pacificar o conflito (escopo social), o que não ocorreria com a mera rejeição do pedido do autor.

Marinoni, nesse sentido, ressalta que, tendo o Código de Processo Civil quebrado o paradigma até então vigente de "tipicidade dos meios executivos", o qual obrigava o juiz respeitar as escolhas feitas pelo exequente quanto aos meios executivos, "torna-se muito mais delicada a problemática dos limites da execução. Se o réu não tem mais a garantia de que a sua esfera jurídica somente poderá ser invadida através das modalidades executivas tipificadas na lei, torna-se ainda mais importante o princípio de que a execução deverá ser feita do modo menos gravoso possível". ${ }^{400}$ Assim complementa o processualista:

\footnotetext{
“O direito deve ser tutelado através do meio mais idôneo, que é aquele que permite a tutela do direito do modo menos gravoso ao réu. E a tutela do direito através do meio mais idôneo deve-se dar de modo a causar a menor restrição possível ao demandado. Assim, por exemplo, se há atividade poluidora, e é suficiente a instalação de determinada tecnologia para que a poluição seja estancada, não há como se admitir a interdição da fábrica que está produzindo a atividade geradora da poluição. Por outro lado, se a tecnologia pode ser instalada sem que sejam paralisadas as
}

${ }^{399}$ Cf. Marinoni, Tutela específica, $2^{\mathrm{a}}$ ed., p. 98; e Tutela inibitória:individual e coletiva, $4^{\mathrm{a}}$ ed., p. 167.

${ }^{400}$ Cf. Marinoni, Tutela específica, $2^{\mathrm{a}}$ ed., p. 128. 
atividades produtivas, a menor restrição possível exige que a instalação não implique a paralisação das atividades do demandado". 401

Dito isso, podemos concluir que o artigo 461 do Código de Processo Civil não apenas trata da solução de problemas decorrentes da inexequibilidade das prestações originariamente demandadas no processo, mas é uma norma direcionada ao juízo decisório, conferindo ao juiz maior liberdade para julgar a causa e conceder a tutela jurisdicional, levando sempre em consideração as especificidades da relação de direito material.

\subsection{MEIOS FORMAIS PARA A CONCESSÃO DO RESULTADO PRÁTICO EQUIVALENTE}

Ressaltamos acima que o respeito ao contraditório é fundamental para que seja possível a aplicação dos efeitos do artigo 461 do Código de Processo Civil, sob pena de serem afetadas as legítimas expectativas das partes, ferindo-lhes o direito de participar e de ter condições de influenciar o resultado do processo. Dito isto, questionamos: seria necessário obedecer a um procedimento específico para tanto?

A resposta é negativa. A lei não faz nenhuma previsão nesse sentido, e é possível que o contraditório seja plenamente respeitado sem que exista a necessidade de iniciação de um novo procedimento ou incidente processual. Isto, no entanto, ocorre apenas quando estamos tratando de resultados práticos equivalentes que podem ser obtidos com base nas provas já previamente produzidas no curso do processo, sejam estas de natureza documental, oral ou pericial.

Ainda que o resultado prático equivalente pressuponha a utilização como premissa de (i) fatos secundários; ou mesmo (ii) de fatos não enunciados na demanda, tendo a ocorrência destes sido verificadas no curso da produção de provas, em total respeito ao contraditório, não há impedimentos para que o juiz os tome como fundamento para a concessão do resultado prático equivalente, desde que, evidentemente, confira nova oportunidade de debate às partes.

401 Cf. Marinoni, Tutela específica, $2^{\text {a }}$ ed., pp. 144-145. Karl Larenz trata desta questão ao cuidar do "princípio da necessidade", que se divide nos princípios do meios mais idôneo e da menor restrição possível”. Cf. Larenz, Metodologia da ciência do direito, p. 585. 
Quando tratamos da relatividade do fato essencial, pudemos observar que o sistema - principalmente por força do iura novit curia - admite a transformação oficiosa de fatos secundários em fatos essenciais, não sendo razoável pensar na sua impossibilidade nas hipóteses do artigo 461 do Código de Processo Civil (cf. item 3.16).

O mesmo ocorreria se estes (i) fatos secundários ou mesmo (ii) fatos não enunciados, necessários para o resultado prático equivalente, embora não tenham sido objeto de prova, possam ser provados pela mera apresentação superveniente de prova documental. Basta autorizar sua apresentação extemporânea e reabrir o amplo contraditório para que, posteriormente, estes possam ser usados como premissa para que o juiz conceda tutela distinta da originariamente pleiteada.

A jurisprudência admite tranquilamente a possibilidade de instauração de incidente cognitivo, inclusive na fase de cumprimento de sentença, exigindo apenas que este se limite a um debate resolúvel apenas a partir da apresentação de prova documental, tal como ocorre nas chamadas "exceções de pré executividade" (cf. STJ, Súmula 393). Ocorre, no entanto, que é possível cogitar a possibilidade de o resultado prático equivalente apenas poder ser conferido por meio da produção ulterior de prova oral ou pericial. Nesses casos, estaria afastada a aplicação do artigo 461 do Código de Processo Civil?

Entendemos que não. O melhor dos mundos seria a possibilidade de o juiz identificar a necessidade de concessão do resultado prático equivalente no curso da fase cognitiva do processo. Fazendo-o, pode alterar ex officio o objeto litigioso do processo e, com base nessa nova referência, dirigir toda a instrução processual em contraditório. Ocorre que normalmente identificamos a necessidade de tutela específica alternativa apenas no fim da instrução ou na fase de cumprimento de sentença. Nesses casos, o que fazer?

Esta hipótese não é distante da realidade já positivada pelo direito processual, o qual prevê, para a hipótese de conversão da tutela específica em tutela genérica, incidente de liquidação de sentença específico para viabilizar a produção ulterior de provas. Assim determina o parágrafo único do artigo 633 do Código de Processo Civil:

“Art. 633. Se, no prazo fixado, o devedor não satisfizer a obrigação, é lícito ao credor, nos próprios autos do processo, requerer que ela seja executada à custa do devedor, ou haver perdas e danos; caso em que ela se converte em indenização. Parágrafo único. O valor das perdas e danos será apurado em liquidação, seguindo-se a execução para cobrança de quantia certa”. 
Por analogia - já que estamos tratando de situações muito similares - é razoável se admitir a possibilidade de utilização deste mesmo incidente para que seja possível, não apenas converter a tutela específica em genérica, mas também para converter a tutela específica original em tutela específica alternativa.

Esta possibilidade pode ser mostrar útil, na medida em que em determinados casos a concessão do resultado prático equivalente depende da demonstração da adequação técnica da tutela alternativa. Esta adequação é representada por fatos novos (não alegados ou que antes não eram considerados fatos essenciais) e que, por este motivo, podem não ter sido objeto de provas, justificando, desse modo, a instrução probatória superveniente. ${ }^{402}$

\subsection{INEXEQUIBILIDADE E CONVERSÃO EM PERDAS E DANOS: AINDA RELATIVIZANDO O OBJETO LITIGIOSO DO PROCESSO?}

Mais antiga, mas muito próxima da conversão em "resultado prático equivalente" está a norma - também dirigida ao processo de execução e fase de cumprimento de sentença - do artigo 633 e do artigo 461, § $1^{\circ}$, do Código de Processo Civil, a qual determina que a possibilidade de conversão do pedido condenatório de obrigação em fazer, não fazer e de dar coisa em "perdas e danos se o autor o requerer ou se impossível a tutela específica ou a obtenção do resultado prático correspondente".

Nunca existiram grandes dificuldades hermenêuticas com essa regra, ao passo que se trata de consequência inevitável da inexequibilidade de tutela específica, tanto do ponto de vista do direito material (CC, art. 234 e 247) quanto do ponto de vista do direito processual. No entanto, não se pode ignorar que a conversão de uma obrigação de fazer ou não fazer, ou mesmo de dar coisa, em obrigação de pagar quantia implica alteração do objeto litigioso do processo.

Pagar quantia em dinheiro é conduta distinta de fazer, não fazer ou mesmo de entregar coisa. Ainda que aquela obrigação seja decorrente do descumprimento destas, não podemos negar que há pressupostos de fato e de direito distintos nos dois casos. Nesta

\footnotetext{
402 Bom exemplo desta possibilidade residiria na tutela alternativa representada pela instalação de filtro em fábrica poluidora, como resultado prático equivalente do pedido de fechamento desta. Em tais casos, é razoável crer que a instalação de filtro somente poderá ser determinada após avaliação técnica de sua viabilidade e adequação, o que pode exigir prova pericial antes não produzida nos autos.
} 
hipótese, entendemos que deve ser aplicado o mesmo raciocínio que expusemos em relação ao "resultado prático equivalente". A técnica processual visa a "operatividade" do sistema, mitigando a exigência de segurança jurídica representada pela norma da congruência, com o objetivo de não desperdiçar toda uma atividade cognitiva, ameaçada pela impossibilidade fática ou jurídica de se efetivar a tutela, tal como originariamente pleiteada.

Por este motivo, a conversão da tutela específica em perdas e danos não deve ser pautada apenas como uma saída para a inexequibilidade das obrigações, mas também como um meio de atender os escopos social e jurídico do processo, permitindo que este propicie resultados mais adequados do ponto de vista do direito material e com maior aptidão para pacificar as relações sociais conflituosas. ${ }^{403}$

\subsection{O CASO DO FATO SUPERVENIENTE}

Seguindo adiante, passamos agora a tratar da norma do artigo 462 do Código de Processo Civil, que trata da possibilidade de o juiz se valer de "fatos novos" - não alegados pelas partes - para efetivar o julgamento do pedido: "Se, depois da propositura da ação, algum fato constitutivo, modificativo ou extintivo do direito influir no julgamento da lide, caberá ao juiz tomá-lo em consideração, de ofício ou a requerimento da parte, no momento de proferir a sentença". ${ }^{404}$

403 O Superior Tribunal de Justiça parece seguir este raciocínio em caso no qual a parte pleiteou o cumprimento específico da obrigação e a Corte, por entender que esta medida depois se tornou excessivamente onerosa, valeu-se do disposto no artigo 461 do Código de Processo Civil para determinar a conversão da tutela específica em tutela genérica, de natureza ressarcitória. Assim restou ementada: “(...) II Independentemente de a impossibilidade ser jurídica ou econômica, o cumprimento específico da obrigação pela recorrida, no caso concreto, demandaria uma onerosidade excessiva e desproporcional, razão pela qual não se pode impor o comportamento que exige o ressarcimento na forma específica quando o seu custo não justifica a opção por esta modalidade ressarcimento; III - É lícito ao julgador valer-se das disposições da segunda parte do $\S 1^{\circ}$ do art. 461 do Código de Processo Civil para determinar, inclusive de ofício, a conversão da obrigação de dar, fazer ou não-fazer, em obrigação pecuniária (o que inclui o pagamento de indenização por perdas e danos) na parte em que aquela não possa ser executada (...)". (STJ, $3^{\mathrm{a}}$ T., REsp 1055822/RJ, Rel. Ministro Massami Uyeda, j. 24/05/2011, DJe 26/10/2011).

404 A doutrina trata do tema direito superveniente e fato superveniente sobre a mesma rubrica. Nesse sentido, Alvaro de Oliveira relata que "no conceito de ius superveniens estão compreendidos o fato e o direito" e ressalta a necessidade se reconhecer a relevância do art. 303, I, do Código de Processo Civil, pois, segundo afirma, a parte, "a não ser expressa autorização legal, poderia ficar inibida de alegar o direito novo pelo princípio da eventualidade adotado pelo Código". (Do formalismo no processo civil, $2^{\mathrm{a}}$ ed., p. 178). Daniel Degenszajn ressalta que "também os fatos podem conferir novo direito ao autor e do mesmo modo estará caracterizado o direito superveniente, que nada mais é do que um direito que incialmente não existia e passou a existir em razão da ocorrência de situações externas ao processo ou mesmo reveladas no próprio 
Em primeiro lugar, a norma mitiga o princípio da eventualidade, ao permitir a alegação de novos fatos "modificativos" ou "extintivos" no ato de resistência ao pedido (defesa). Trata-se, aqui, de alegações de fato do réu que, em tese, teriam o condão de modificar os efeitos do pedido do autor ou impedir sua produção (pela extinção do direito subjetivo/potestativo), ampliando o objeto cognitivo do processo. Isto é relevante, pois o Código de Processo Civil, nos termos do seu artigo 300, caput, estipula em face do réu preclusão temporal quanto a determinadas matérias de defesa. ${ }^{405}$

Grosso modo, esta preclusão atinge apenas as vulgarmente chamadas "exceções substanciais" ou "exceções em sentido estrito", que não integram a ordem pública, "seja porque sua base normativa é de normas dispositivas, seja porque os interesses que a norma visa a tutelar são eminentemente particulares". ${ }^{406}$ Assim e.g. cabe ao réu concentrar em sua defesa todas suas alegações pertinentes a fatos extintivos como a compensação (CC, art. 380) ou o pagamento (CC, art. 304) ou fatos modificativos como a resolução do contrato por onerosidade excessiva (CC, art. 478)..$^{407}$

Em segundo lugar, e agora com repercussões relevantes para esta tese, a norma autoriza a alteração da causa de pedir remota (alteração do objeto litigioso do processo), com fundamento na ocorrência de fato superveniente à propositura da demanda. Até o momento, cuidamos de normas que permitiam a alteração do pedido ou a relativização da

processo, mas desconhecidas no momento da propositura da demanda". (Alteração dos fatos no curso do processo, p. 104). Na mesma linha, Guilherme Freire de Barros Teixeira defende o tratamento uniforme de ambas, afirmando que os efeitos para o processo seriam os mesmos ( $O$ princípio da eventualidade no processo civil, p. 249).

Entendemos que a questão do "direito superveniente" é muito distinta da questão do "fato superveniente", não merecendo tratamento uniforme. Estas, à luz de nosso ordenamento jurídico, tem fundamentos normativos e razões-de-ser diferentes. O "fato novo" se fato secundário, pode ser alegado a qualquer tempo pela falta de preclusão (não incide sobre eles a regra da estabilização da demanda), se fato essencial, conforme demonstraremos, pode ser alegado posteriormente com base no art. 462 do Código de Processo Civil. O direito, no entanto, para ser alegado posteriormente, não precisa sequer ser novo, ao passo que se aplica a regra do iura novit curia, conforme analisamos no item 3.15.

405 Guilherme Freire de Barros Teixeira se vale do "princípio da eventualidade" em sua chamada definição "ampliativa", que cuidaria tanto do "ataque" quanto da "defesa". Referindo-se basicamente à doutrina italiana (Antonio Segni e Gian Franco Ricci), trata sob o mesmo termo do objeto litigioso do processo (elementos da demanda) e do objeto cognitivo do processo, ao afirmar que "a definição ampliativa abrange indistintamente o autor e o réu, impondo a ambos o ônus da alegação concentrada de suas alegações, pedidos, exceções e elementos de prova" (cf. O princípio da eventualidade no processo civil, p. 24-25 e p. 160).

Entendemos que as normas aplicáveis $(i)$ aos limites impostos à alteração dos elementos da demanda; e (ii) aos limites impostos à alteração do objeto cognitivo do processo são distintas, o que torna - senão inadequada - perigosa o tratamento destas duas questões sob o mesmo rótulo.

${ }^{406}$ Cf. Ricardo Aprigliano, Ordem pública e processo, p. 120.

407 É importante ressaltar que, para que possamos falar aqui na aplicação do artigo 462 do Código de Processo Civil, temos de considerar apenas as exceções substanciais, passíveis de preclusão, ao passo que as chamadas objeções (matérias de ordem pública) podem ser conhecidas, ainda que de ofício, a qualquer tempo, não precisando se caracterizarem como "fatos novos". Cf. Ricardo Aprigliano, Ordem pública e processo, p. 115. 
congruência em relação a este elemento da demanda. A regra ora analisada, diferentemente, cuida da relativização da congruência sob a perspectiva da causa de pedir fática.

Grande parte dos julgados a tratar do tema cuida do "fato superveniente" na perspectiva de fatos secundários, normalmente se pauta em "fatos novos" relevantes para aspectos processuais, tais quais o reconhecimento da carência de uma das condições da ação ou pressupostos processuais. No Colendo Superior Tribunal de Justiça é assente a declaração de que a previsão legal citada representaria a possibilidade de a coisa julgada, formada supervenientemente à propositura da demanda, poder vir a ser alegada pela parte interessada, ou mesmo reconhecida ex officio. ${ }^{408}$

Ocorre que entender que a norma do artigo 462 do Código de Processo Civil se aplicaria apenas aos fatos secundários significaria não dar nenhum sentido ou eficácia a este texto legal.

A regra da estabilização da demanda, assim como a regra da correlação, somente se aplica aos elementos identificadores da demanda. Os fatos secundários, com efeito, por não servirem para tanto, não se submetem a estes parâmetros e, portanto, podem ser alegados a qualquer tempo. Isto significa que questões relevantes para o processo, tal como a litispendência ou a coisa julgada, ou ainda questões relevantes para a formação de presunções hominis, sem constituírem o direito pleiteado, não precisam ser considerados "fatos novos" para poderem ser alegadas a qualquer tempo, fazendo absolutamente desnecessária qualquer remissão ao artigo 462 do Código de Processo Civil.

Desse modo, entendemos que - exatamente pelo fato de a lei não conter palavras inúteis - o referido dispositivo deve ser compreendido como norma que permite, verdadeiramente, a alteração dos elementos da demanda. Mais uma vez, esta possibilidade de alteração do objeto litigioso do processo tem fundamento na exigência de efetividade e adequação - não da técnica processual - mas do resultado do processo, que deve ser adaptável à alteração das circunstâncias da relação de direito material. 409

\footnotetext{
408 Nesse sentido, vejamos: "1. O julgamento deve refletir o estado de fato da lide no momento da entrega da prestação jurisdicional. 2. O fato superveniente (art. 462 do CPC) deve ser tomado em consideração no momento do julgamento a fim de evitar decisões contraditórias e prestigiar os princípios da economia processual e da segurança jurídica.3. No caso dos autos, o fato superveniente - consubstanciado na coisa julgada produzida em lide (ação declaratória) que tramitava paralelamente ao processo de execução que deu origem aos presentes autos - é tema relevante e deve guiar a solução do presente recurso especial sob pena ofensa à coisa julgada. 4. Recurso especial provido para restabelecer a decisão de primeira instância. (STJ, $3^{a}$ T., REsp 911932/RJ, Rel. Ministro Ricardo Villas Bôas Cueva, j. 19/03/2013) No mesmo sentido, cf. STJ, 4 ${ }^{\mathrm{a}}$ T., REsp 604377/MA, Rel. Ministro Aldir Passarinho Junior, j. 19/05/2005.

${ }^{409}$ Cf. Galeno Lacerda, “O código e o formalismo processual”, p. 18; Daniel Degenszajn, Alteração dos fatos no curso do processo, p. 100.
} 
A sociedade e os fatos sociais se alteram com o tempo, ao passo que a lentidão e a demora da atividade processual - e que é a ela inerente - não pode servir como fundamento para inviabilizar o instrumento estatal. Os escopos do processo representam sua função constitucional e a técnica, visando a estes objetivos, deve preservar ao máximo a operatividade do processo.

Esta possibilidade possui especial relevância nas hipóteses de relações continuativas. Podemos citar o exemplo de demanda com pedido constitutivo negativo de contrato de fornecimento mensal de mercadorias fundado em fatos que configuram o inadimplemento (resolução). Ocorre que, no curso do processo, fato novo ocorre de modo a justificar a onerosidade excessiva da prestação. Com base na norma do artigo 462 do Código de Processo Civil seria lícito ao juiz tomar os fatos novos que configuram "onerosidade excessiva" como fundamento para julgar procedente o pedido e anular o contrato.

Em acréscimo, a hipótese é relevante para as demandas ressarcitória e inibitórias, as quais podem ser afetadas pela alteração da natureza ou pela própria ocorrência do dano no curso do processo. Pensemos no exemplo da ação de reparação de danos, fundada originariamente em lesões corporais, e que, no curso do processo, é afetada pela ocorrência da morte da vitima lesionada. Desse modo, ocorrendo alteração relevante no âmbito da relação de direito material, que tenha aptidão para configurar novo fato jurígeno (fato essencial) em relação aos pedidos formulados, deve este fato novo ser admitido, visando sempre a evitar o desperdício de atividade jurisdicional e a pacificar a relação conflituosa.

\subsection{ALTERAÇÃO POR “FATOS SUPERVENIENTES”: LIMITAÇÕES}

A possibilidade prevista pelo artigo 462 do Código de Processo Civil, como visto, cuida de fatos essenciais, e não se fatos secundários. No entanto, o dispositivo autoriza uma mudança apenas parcial, de apenas um dos elementos da demanda: causa de pedir fática. Não há previsão para que ocorra alteração do pedido ou mesmo das partes em função de fato novo. ${ }^{410}$

\footnotetext{
${ }^{410}$ Em relação às partes, seria possível que fatos novos autorizem sua alteração apenas nos casos previstos de sucessão processual (CPC, art. 43).
} 
Desse modo, com base na ocorrência de fato superveniente ao ajuizamento da demanda, não pode a parte querer formular outro pedido ou mesmo alterar os sujeitos parciais do processo: pode apenas alegar outra causa de pedir fática que, assim como as previamente alegadas, tenha a aptidão de produzir exatamente o mesmo efeito pleiteado com o pedido.

Precisamos cuidar de hipótese clássica de concurso de normas, pela qual o mesmo pedido poderia se fundamentar em mais de uma causa de pedir ao mesmo tempo. $\mathrm{Na}$ hipótese do artigo 462 do Código de Processo Civil, teríamos uma (ou mais) causa de pedir pautada em fato anterior à demanda e outra causa de pedir - inovada no curso do processo - pautada em fato superveniente. Isto é, não um fato supervenientemente alegado, mas um fato que ocorreu posteriormente à data da propositura da demanda e que, ao lado dos fatos alegados nesta, tem aptidão de gerar os efeitos pleiteados com o pedido. ${ }^{411}$

Nesse sentido, e falando desta hipótese, a principal restrição à admissibilidade do "fato novo" está na obrigação deste manter relação de pertinência com a causa de pedir original. Assim o faz Guilherme Freire de Barros Teixeira, mencionando que seria possível “o reconhecimento de conduta desonrosa do cônjuge réu após o ajuizamento da demanda e que seja admitida como causa concorrente para a decretação da separação judicial" e que "nos exemplos do agravamento das lesões decorrentes do mesmo ato lesivo em uma ação de indenização por ato ilícito ou da modificação da situação financeira do réu, no curso de uma ação de alimentos, passa a ganhar salário mais alto (ou mais baixo) do que no início do processo, os fatos modificativos supervenientes devem ser apreciados na sentença”. ${ }^{412}$

Bedaque, seguindo linha similar, acresce outro elemento limitador. Assim como nas demais hipóteses tratadas de alteração do objeto litigioso, o processualista acertadamente ressalta a necessidade deste fato novo, antes de ser admitido como premissa para o julgamento de mérito, ser submetido ao contraditório:

411 Cruz e Tucci, ao interpretar o artigo 462, aceita a possibilidade de alteração dos elementos da demanda, restringindo a aceitação de "fato novo" no processo. ( A causa pretendi no processo civil, $2^{\mathrm{a}}$ ed., pp. 176-178). No mesmo sentido parece referir-se Alvaro de Oliveira, Do formalismo no processo civil, $2^{\mathrm{a}}$ ed., p. 177, nota 124 e Galeno Lacerda, "O código e o formalismo processual", Ajufes 28/13.

412 Entendemos serem adequados os exemplos citados acima. No entanto, não concordamos com as menções do autor quanto aos supostos fatos extintivos: "o perecimento do bem vindicado durante o curso do processo ou a desapropriação pelo Poder Público do imóvel objeto da ação de reintegração de posse em curso, ou ainda, o casamento superveniente da alimentanda em ação de exoneração de alimentos". Em primeiro lugar, pois o perecimento do bem é matéria de defesa, e não implica em alteração da causa de pedir. Em segundo lugar, pois o casamento da ré em ração de exoneração de alimentos é fato constitutivo do direito do autor (constitui o seu direito de não mais pagar alimentos), e não fato extintivo. É importante asseverar que os fatos constitutivos são aqueles que tem aptidão para desencadear os efeitos pleiteados com o pedido, no caso, o efeito desejado era a exoneração de alimentos, cujo fato constitutivo é a caracterização do fim do dever de pagar, da extinção da obrigação (cf. Guilherme Freire de Barros Teixeira, O princípio da eventualidade no processo civil, pp. 260-261). 
Desde que observado o contraditório, prejuízo nenhum há de se admitirirmos a introdução de verdadeiras causa de pedir novas, representadas por fatos supervenientes diversos daqueles afirmados na inicial, mas constitutivos do mesmo direito pretendido pelo autor. Esta solução tem como consequência direta a desnecessidade da propositura de nova demanda. A regra da estabilidade somente se justifica diante de fatos já existentes à época da propositura da demanda, pois o autor poderia tê-los invocado. Quanto aos posteriores, nada obsta a que sejam aproveitados no mesmo instrumento. A exceção é compatível com a visão instrumentalista do direito processual, além de conferir efetividade e economia. ${ }^{413}$

Verificamos desse modo limitadores claros à admissibilidade de fatos superveniente no processo civil. Em primeiro lugar, o fato deve ocorrer ou apenas poder ser conhecido - e não simplesmente ser alegado - em data posterior à propositura da demanda, em segundo lugar, o fato deve ser apto a produzir os mesmos efeitos jurídicos já pleiteados com a demanda (sendo vedado novo pedido) e, em terceiro lugar, a utilização de fato novo para decidir depende do prévio respeito ao princípio do contraditório.

\subsection{ALTERAÇÕES ILEGAIS DO OBJETO DO PROCESSO: PROBLEMA DIFERENTE}

Até o presente momento, admitimos varias possibilidades previstas pela lei de alteração do objeto litigioso do processo, de modo que ocorresse o rompimento da correlação entre o conteúdo da demanda e da tutela jurisdicional. Estas exceções legais visam a assegurar os escopos do processo e devem observar uma série de restrições, todas relacionadas ao respeito à vontade das partes e ao princípio do contraditório.

Ocorre que a realidade é complexa e, por este motivo, é muito comum ocorrer incongruência entre demanda e tutela jurisdicional, mesmo nos casos não autorizados pela lei. O debate processual, por imperfeições da demanda não detectadas ou mesmo por um desvio - intencional ou não - decorrente do contraditório ou da produção das provas, pode

413 Cf. Bedaque, Efetividade do processo e técnica processual, p. 136. A mesma exigência de contraditório é ressalvada por Picó i Junoy, em referência à LEC espanhola: "En la medida en que hechos relevantes para la decisión del pleito se produzcan con posterioridad a la interposición de la demanda, o sean anteriores pero desconocidos por el actor, debe permitir-se su introducción al proceso ya que la aplicación de la rígida preclusión de hechos del art. 400 LEC exige para su admisión la audiencia previa al demandado, para que pueda defenderse sobre los nuevos hechos; y una rigurosa prueba de las circunstancias que justifican esta modificación de la demanda". (La modificación de la demanda en el proceso civil, 113) 
permitir que a Jurisdição acabe por implementar tutela distinta daquela demandada, desrespeitando os limites do objeto litigioso do processo já devidamente estabilizado.

Estamos falando de caso inequívoco de irregularidade processual, por descumprimento basicamente do artigo 468 do Código de Processo Civil. A sentença pode ofender a congruência por decidir ( $i$ ) menos do que o pleiteado (infra petita); mais do que o pleiteado (ultra petita) ou diferente do que pleiteado (extra petita). A congruência tem como objetivo resguardar a garantia da inércia e do contraditório, é pode este motivo que o juiz deve se ater ao limites da demanda, conforme expusemos acima (cf. item 6.3). Desse modo, a irregularidade processual decorrente do descumprimento desta regra deve acarretar prejuízo a estes princípios - impedir o respeito à inércia e ao contraditório - e, por consequência, configurar a nulidade processual.

A sentença e o processo serão nulos a partir do momento em que e regra da congruência é ofendida (irregularidade processual), de modo a impedir que tenha ocorrido o respeito à vontade da parte (inércia) e o adequado debate processual (contraditório). Este é o prejuízo que deve se aderir a irregularidade formal, de modo a configurar a nulidade dos atos processuais.

As normas formais no processo tem uma razão de ser, e o ordenamento jurídico presume (presunção iuris tantum) que, uma vez descumprida a forma legal (irregularidade formal), o ato processual não mais terá o condão de atingir seus escopos específicos (CPC, art. 244). Ocorre que, em muitos casos, a despeito da irregularidade formal, o ato processual pode excepcionalmente atingir seus objetivos, evitando a nulidade.

Isto, com efeito, pode ocorrer em relação à congruência. A despeito de a Jurisdição haver concedido tutela fora dos limites demandados - em caso não autorizado especialmente pela lei - é possível conceber a possibilidade desta irregularidade não acarretar prejuízo para os escopos específicos da norma: inércia e contraditório. Basta que a tutela concedida - a despeito de não demandada no momento adequado - tenha sido aceita expressamente pelo demandante, no curso do debate processual, e tenha sido submetida a real e efetivo contraditório.

Teríamos descumprimento das formas legais, no entanto, este descumprimento, por não gerar prejuízo, tal como determina a regra da instrumentalidade das formas, não deverá configurar qualquer nulidade processual, mantendo-se a aptidão de o processo produzir seus efeitos jurídicos.

Pensemos em demanda com pedido de reparação em danos materiais em face de empresa telefônica, na qual toda a contestação, réplica e prova oral produzida diz respeito 
- e debate efetivamente - a ocorrência ou não de danos morais. Caso proferida sentença, condenando o réu ao pagamento de danos morais, estaríamos diante de inquestionável irregularidade processual (ofensa ao art. 460), no entanto, a norma da instrumentalidade das formas não autorizaria a declaração de nulidade da sentença, tendo em vista que, a despeito da irregularidade, o objetivo específico da norma foi atingido, com o pleno respeito à vontade da parte (que aceitou os danos morais em réplica) e ao contraditório (contestação e instrução probatória).

O mesmo, com efeito, pode ocorrer com alteração da causa de pedir. Para Bedaque, "se, inadvertidamente, for introduzida no processo causa de pedir não deduzida na inicial e o contraditório abranger a nova realidade fática, não há por que desconsiderála. As regras da correlação, da eventualidade e da preclusão visam a assegurar a amplitude da defesa e o normal desenvolvimento do processo". Assim, o processualista cita julgamento de recurso de apelação, no qual, após propiciar a renovação do contraditório, admitiu a validade de sentença que acolheu pedido formulado em mandado de segurança com base em causa de pedir deduzida "posteriormente à notificação da autoridade impetrada":414

"Decidiu-se assim por considerar, no caso, irrelevante a não-observância da forma, pois a providência determinada foi suficiente para restabelecer a segurança e manter íntegro o contraditório. Diante de eventual vício processual, deve o juiz tentar saná-lo. Somente se impossível essa alternativa, porque a falha comprometeu definitivamente a ampla defesa e o contraditório, a anulação torna-se a opção adequada. O que importa, em um primeiro momento, é o fim do processo -- qual seja, a solução justa para o litígio".

Esta conclusão trata de uma consequência do sistema formal do Código de Processo Civil, que adota formas e procedimento rígido, mas que somente autoriza a nulidade do ato processual irregular que traz prejuízo. A mera irregularidade, no caso, descumprimento da correlação, se não causar prejuízo à vontade da parte e à inércia, não pode por si só justificar a nulidade do ato processual e do processo.

É importante ressaltar, no entanto, que tratamos aqui - assim como o fazemos em toda a teoria das nulidades processuais - sempre de uma análise retrospectiva. A aplicação da instrumentalidade das formas é medida que visa a evitar o desperdício de atividade

${ }^{414}$ Efetividade do processo e técnica processual, pp. 132-133. 
processual, mantendo a validade de ato processual irregular, desde que este tenha atingido seus objetivos.

Este raciocínio, com efeito, somente é aplicado depois de identificada a irregularidade e visa a minorar suas consequências negativas. Isto não pode ser confundido com uma autorização prévia para descumprimento das formas processuais. O juiz deve sempre respeitar os limites do objeto litigioso do processo, escusando-se a decidir menor, mais ou diferente do que foi pedido. Não é desejável que esta regra - fora das exceções legais - seja descumprida por nenhum juiz, e a instrumentalidade das formas não incentiva nem encoraja este descumprimento, tudo que faz é tentar evitar a anulação do processo nas hipóteses em que desrespeito de fato acontece. ${ }^{415}$

${ }^{415}$ A respeito da análise retrospectiva que diz respeito à adequada aplicação das instrumentalidade das formas, cf. Bedaque, Efetividade do processo..., pp. 498-502. 


\section{CONCLUSÕES}

A demanda é uma demanda porque direcionada ao Estado e porque elaborada, dentro de determinadas condições, por agente autorizado para tanto. Além disso, é uma demanda porque apresenta um conteúdo linguístico específico, que a caracteriza como ato argumentativo que exerce determinada função no sistema processual: instituir ou alterar o objeto litigioso do processo.

Definimos pedido como um elemento constitutivo de um ato formal de natureza linguística (i.e. demanda) que possui um certo conteúdo. Se de um modo geral a demanda - que o contém - é um ato linguístico, exteriorizado por letras, palavras e orações expostas em um suporto físico, também o é o pedido. Este conteúdo se divide em dois $(i)$ pedido imediato, representado pelo ato de poder específico e pela técnica processual que se quer obter do Estado-juiz; e (ii) pedido mediato, representado pelo bem da vida (transformação da realidade) almejado pelo demandante.

A causa de pedir fática ou remota seria constituída pela descrição dos fatos aptos - uma vez subsumidos às normas pertinentes - a produzirem os efeitos jurídicos pretendidos no pedido. Cuidamos dos fatos relevantes, dos acontecimentos da vida narrados nas suas miudezas (teoria da substanciação) e que de acordo com as afirmações do demandante estariam aptos da constituírem o direito demandado (efeitos jurídicos).

A causa de pedir próxima, por sua vez, seria representada pela descrição da norma jurídica (enunciado prescritivo) que, uma vez aplicada aos fatos descritos como causa de pedir remota, teria o condão de desencadear os efeitos jurídicos almejados com o pedido.

Por força do iura novit curia, podemos dizer que apenas a causa de pedir remota tem o condão de individualizar o objeto litigioso do processo, tendo em vista que, ainda que alteremos a causa de pedir próxima, estaremos a tratar de uma mesma demanda.

A causa de pedir divide-se, ainda, em ativa e passiva. Na primeira temos a alegação dos fatos jurídicos que fazem surgir os direitos e as obrigações, cujos efeitos em concreto queremos ver produzidos com o pedido. A segunda, por sua vez, é formada pela descrição da crise, que faz nascer a necessidade de utilização do instrumento estatal de resolução de controvérsias (interesse processual), e que será responsável por efetuar a individualização da norma abstrata e aplicação da sanção. 
O conceito de parte é um conceito processual, parte é (i) sujeito parcial da relação jurídica processual, (ii) com interesse privado na causa, (iii) que formula demanda ou em face de quem a demanda foi formulada e que, de algum modo, (iv) participa do contraditório, $(v)$ podendo ser afetada pelos efeitos jurídicos da sentença (efeitos principais) e da coisa julgada material, quando pertinente.

Definidos os elementos que representam o conteúdo da demanda, e que servem para individualizá-la, ressaltamos que este conteúdo decorre sempre da compreensão de um ato linguístico, motivo pelo qual deve necessariamente ser interpretado. A interpretação do pedido não pode partir de uma leitura isolada da oração - normalmente aportada ao fim da demanda - pela qual a parte designa sua vontade relativamente a um determinado bem da vida. O que importa é que esta vontade seja clara e manifesta, de modo que sua compreensão - à luz do que normalmente acontece naquele contexto - possa ser razoavelmente exigida do demandado e dos demais sujeitos que participam do contraditório.

Embora existam exceções legais que autorizem o juiz a conceder bens da vida não pleiteado pelas partes, as quais a doutrina logrou chamar de pedidos "implícitos", resta claro que os pedidos - verdadeiramente pedidos - têm de possuir um conteúdo, uma manifestação de vontade clara e explícita, de modo que a admissão de pedidos tácitos ou verdadeiramente implícitos não pode ser aceita pelo sistema processual, na medida em que não garantiria o respeito à inércia e ao contraditório.

No chamado "juízo de identificação de demandas", identificamos o que deve existir - de específico - em um ato processual para que ele possa ser chamado de demanda, é dizer, qual é o conteúdo que a identifica. Entendemos que esta análise é inevitável, muito embora na grande maioria das vezes a identificação dos atos processuais ocorra de modo quase que imperceptível, sem grandes ou nenhum problema.

O nome atribuído ao ato postulatório e a forma de exteriorização do ato, por si só, não são aptos a configurarem um ato postulatório como demanda. A demanda se configura como tal a partir do seu conteúdo (manifestação de vontade) e da função que exerce no sistema processual.

Dentro da categoria dos atos postulatórios, difere-se dos demais atos, tais quais os recursos, requerimentos de provas, defesas e demais alegações das partes, pela manifestação de vontade quanto a produção de determinados efeitos jurídicos. Especialmente, pela eficácia criadora do dever do Estado-Jurisdição em apreciar um pedido de tutela jurisdicional (mérito), sem o qual não teria condições de apreciar. 
A função do ato, portanto, que classifica a demanda como tal, recebe um acréscimo, para que a demanda se insira na subcategoria demanda inicial; não basta que se trate de um ato da parte de natureza postulatória e argumentativa que tenha por objetivo romper a inércia e formular novo pedido, é necessário que, além disso, este ato tenha uma função de instituir o objeto de um processo, dando-lhe início.

As demandas ulteriores, por sua vez, são aquelas que detêm a função específica de alterar o objeto de um processo já em curso. A possibilidade de formulação de demandas ulteriores estaria inicialmente franqueada ao autor, mas também o réu e os terceiros estão autorizados a formulá-las, nos casos e.g. de reconvenção, oposição e intervenção litisconsorcial.

As defesas de mérito que veiculam pedido de tutela jurisdicional muito se assemelham à demanda, e podem culminar no reconhecimento de direitos em favor do réu. Ocorre que, embora aceitemos a formulação de "demandas informais", no ato da contestação (reconvenções sem peça autônoma), não entendemos seja possível interpretar toda "exceção substancial" como demanda. É necessário que, além disso, a vontade de demandar seja inequívoca, de modo que se possa impor ao autor o ônus de uma resposta adequada.

Apenas o ato de vontade da parte que tenha como objetivo veicular pretensão quanto a um bem da vida tem a eficácia de alterar o objeto litigioso do processo. Desse modo foi concebido nosso sistema processual pelo legislador (CPC, art. 128 e 460). Esta é a regra geral, e funciona na maioria dos casos.

Isto pode apenas ser excetuado diretamente pela lei. Há determinadas condutas meramente defensivas, que não têm como conteúdo a manifestação de vontade clara e expressa quanto à obtenção de um bem da vida, às quais a lei atribui a possibilidade de produzir efeitos análogos aos de uma demanda. Há, também, casos em que a lei prevê a possibilidade de o juiz decidir sem demanda ou defesa. Cuidamos aqui apenas de exceções que comprovam a regra.

A noção tradicional de correlação é estabelecida pelo comparativo de dois atos processuais: a demanda e a sentença. Tanto isso é verdade, que esta norma jurídica é usada para fundamentar a nulidade dos atos decisórios do juiz que (i) decidem menos do que foi demandado (sentença infra petita); (ii) decidem mais do que foi demandado (sentença ultra petita); e (iii) decidem algo distinto do que foi demandado (sentença extra petita).

A sentença não é o ato fim da atividade jurisdicional, em muitos casos, é mero pressuposto de atividade ulterior capaz de satisfazer a pretensão das partes (especialmente 
nas tutelas condenatórias). Por isso, tratamos da correlação entre demanda e tutela jurisdicional.

A correlação existe porque o Estado-juiz é obrigado a responder à demanda (inafastabilidade) e pode apenas apreciar aquilo que foi efetivamente demandado (inércia), nada a mais, nada a menos e nada diferente.

A estabilização comporta exceções. A lei prevê a possibilidade de o objeto litigioso do processo ser alterado, mesmo depois da citação e sem anuência do réu, por meio das chamadas demandas ulteriores. Estas podem partir da iniciativa das próprias partes (demandas ulteriores); do autor com a chamada "ação declaratória incidental", do réu com a "reconvenção" e "denunciação da lide" e, ainda, de terceiros, como ocorre nas hipóteses de "oposição" e de "intervenção litisconsorcial".

Outra exceção reside na regra do artigo 461 do Código de Processo Civil, que autoriza o juiz a flexibilizar a congruência, concedendo a parte "resultado prático equivalente", que nada mais é do que objeto litigioso distinto do que inicialmente pleiteado pela parte.

O resultado prático equivalente é técnica processual que visa a evitar a tutela genérica, privilegiando uma resposta jurisdicional que, embora não correspondente ao pedido formulado, aproxima-se deste. Isto significa que, em primeiro lugar, desejamos a concessão do efeito demandado pela parte e, apenas em segundo lugar, para evitar a tutela ressarcitória, admitimos o resultado prático equivalente.

A ponderação de princípios - feita previamente pelo legislador - permite que, neste caso específico, a previsibilidade quanto ao resultado do processo (que se limitaria ao acolhimento ou à rejeição do pedido formulado) seja conformada com a necessidade de o sistema processual conceder decisões mais justas e tendentes à pacificação da crise de direito material. Por isso, a norma do artigo 461 deve ser interpretada, não apenas à luz da inexequibilidade da tutela originária, mas também à luz do princípio da menor onerosidade previsto pelo artigo 620 do Código de Processo Civil.

Muito próxima da conversão em "resultado prático equivalente" está a norma também dirigida ao processo de execução e fase de cumprimento de sentença - do artigo 633 e do artigo 461, $\S 1^{\circ}$, do Código de Processo Civil, a qual determina que a possibilidade de conversão do pedido condenatório de obrigação em fazer, não fazer e de dar coisa em "perdas e danos se o autor o requerer ou se impossível a tutela específica ou a obtenção do resultado prático correspondente". 
Em relação a esta hipótese, entendemos que deve ser aplicado o mesmo raciocínio que expusemos em relação ao "resultado prático equivalente". A técnica processual visa a "operatividade" do sistema, mitigando a exigência de segurança jurídica representada pela norma da congruência, com o objetivo de não desperdiçar toda uma atividade cognitiva, ameaçada pela impossibilidade fática ou jurídica de se efetivar a tutela, tal como originariamente pleiteada.

Por fim, a lei também autoriza mudança no objeto litigioso do processo a partir da ocorrência de fatos novos, relevantes para processo pendente. A possibilidade prevista pelo artigo 462 do Código de Processo Civil, como visto, cuida de fatos essenciais, e não se fatos secundários. No entanto, o dispositivo autoriza uma mudança apenas parcial, de apenas um dos elementos da demanda: causa de pedir fática.

Não há previsão para que ocorra alteração do pedido ou mesmo das partes em função de fato novo. Desse modo, com base na ocorrência de fato superveniente ao ajuizamento da demanda, não pode a parte querer formular outro pedido ou mesmo alterar os sujeitos parciais do processo: pode apenas alegar outra causa de pedir fática que, assim como as previamente alegadas, tem a aptidão de produzir exatamente o mesmo efeito pleiteado com o pedido. Em todos estes casos, deve-se buscar o máximo respeito possível à vontade das partes e ao princípio do contraditório, sempre concedendo oportunidades para participação e diálogo no processo.

Fora dos casos legais, e agora tratando de uma patologia, o objeto litigioso do processo pode ser alterado por equívoco, provocando desrespeito à norma da congruência. Ocorre que, a despeito de a Jurisdição haver concedido tutela fora dos limites demandados - em caso não autorizado especialmente pela lei - é possível que esta irregularidade não acarrete prejuízo para os escopos específicos da norma: inércia e contraditório. Basta que a tutela concedida - a despeito de não demandada no momento adequado - tenha sido aceita expressamente pelo demandante, no curso do debate processual, e tenha sido submetida a real e efetivo contraditório, tendo o demandado se manifestado da forma mais ampla possível a seu respeito.

Teríamos nesse caso um descumprimento das formas legais, no entanto, este descumprimento, por não gerar prejuízo, tal como determina a regra da instrumentalidade das formas, não deverá configurar qualquer nulidade processual, mantendo-se a aptidão de o processo produzir seus efeitos jurídicos. 


\section{REFERÊNCIAS}

ABELHA RODRIGUES, Marcelo. Ação civil pública e meio ambiente. 2. ed., Rio de Janeiro: Forense Universitária, 2004.

. Manual de direito processual civil. $4^{\mathrm{a}}$ ed. São Paulo: RT, 2008.

Manual de execução civil. $4^{\mathrm{a}}$ ed., rev. e atual. Rio de Janeiro: Forense Universitária, 2009.

ALLORIO, Enrico. “L'ordinamento giuridico nel prisma dell'accertamento giudiziale". Problemi di diritto. Milano: Giuffrè, 1957.

ALVARO DE OLIVEIRA, Carlos Alberto. Do formalismo no processo civil. $2^{\mathrm{a}}$ ed. rev. e atual. São Paulo: Saraiva, 2003.

. "O processo civil na perspectiva dos direitos fundamentais". Revista de Direito

Processual Civil 26. Curitiba: Gênesis, outubro-dezembro/2002.

. "Poderes do juiz e visão cooperativa do processo". Revista da Faculdade de Direito da Universidade de Lisboa 1 e 2- VLIV. Coimbra: Coimbra Editora, 2003.

AMARAL SANTOS, Moacyr. "Nulidades processuais". Enciclopédia Saraiva do Direito. Vol. 55. São Paulo: Saraiva, 1980.

AMENDOEIRA JÚNIOR, Sidnei. Fungibilidade de meios (conversão do ato praticado no processo civil brasileiro e possibilidade de escolha dentre meios processuais postos à disposição das partes). Tese de Doutorado apresentada à Banca Examinadora da Faculdade de Direito da Universidade de São Paulo. São Paulo: USP, 2006.

Poderes do juiz de tutela jurisdicional. A Utilização Racional dos Poderes do Juiz como Forma de Obtenção da Tutela Jurisdicional Efetiva, Justa e Tempestiva. São Paulo: Atlas, 2006.

AMERICANO, Jorge. Da acção rescisoria dos julgados no direito brasileiro. $2^{\mathrm{a}}$ ed. São Paulo: Saraiva, 1926.

AMIGO, Bianca Neves. "A natureza jurídica do resultado prático equivalente”. Revista de Processo 152. São Paulo: RT, outubro de 2007. 
ANDOLINA, Ítalo. Cognizione ed esecuzione forzata nel sistema della tutela giurisdizionale. Milano: Giuffrè, 1983.

ANDRIOLI, Virgilio. Lezioni di diritto processuale civile. Napoli: E. Jovene, 1961.

APRIGLIANO, Ricardo de Carvalho. Ordem pública e processo. O tratamento das questões de ordem pública no direito processual civil.São Paulo: Atlas, 2011.

ARAZI, Roland (et. al). Debido proceso. Realidad y debido proceso. El debido proceso y la prueba. $1^{\mathrm{a}}$ ed. Santa Fe: Rubizinal-Culzoni, 2003.

ARENHART, Sérgio Cruz. "Reflexões sobre o princípio da demanda". In: FUX, Luiz, NERY JR, Nelson e WAMBIER, Teresa Arruda Alvim (coord.). Processo e Constituição. Estudos em homenagem ao Professor José Carlos Barbosa Moreira. São Paulo: RT, 2006. ARRUDA ALVIM, José Manoel de. Tratado de direito processual civil. $2^{\mathrm{a}}$ ed. rev. e ampl. São Paulo: RT, 1996.

. Manual de direito processual civil. $6^{\text {a }}$ ed. rev. e atual. São Paulo: RT, 1997.

. "Principios fundamentales y formativos del procedimiento civil brasileño". Revista de Processo 38. São Paulo: RT, abril-junho de 1985.

. "As normas processuais civis". In: FERRAZ, Sérgio (coord.). A norma jurídica. Rio de Janeiro: Freitas Bastos, 1980. p. 49 e ss.

Direito processual civil: teoria geral do processo de conhecimento. São Paulo: RT, 1972.

ASSIS, Araken de. Manual dos Recursos. São Paulo: RT, 2007.

Cumprimento de sentença. $3^{\mathrm{a}}$ ed. Rio de Janeiro: Forense, 2010.

AUSTIN, John L. How to do things with words. Cambridge : Harvard University Press, 1962.

AZEVEDO, Antônio Junqueira de. "O direito pós-moderno e a codificação". Revista da Faculdade de Direito. Vol. 94. São Paulo: USP, 1999.

"Nulidade parcial de ato normativo. Certeza e segurança jurídica diante de alteração de jurisprudência consolidada. Aplicação da boa-fé objetiva ao Poder Público”. Revista Trimestral de Direito Civil. Vol. 24. Rio de Janeiro: PADMA, outubro-dezembro de 2005. 
Conceito, identificação e conexão de causas no direito processual civil. São Paulo: SCP, 1967.

BARBOSA MOREIRA, José Carlos. O Juízo de admissibilidade no sistema dos recursos civis. Rio de Janeiro: s/ed., 1968.

. "Efetividade do processo e técnica processual". Temas de direito processual Civil: Sexta série. São Paulo: Saraiva, 1997.

. “Que significa 'não conhecer' de um recurso?” Temas de direito processual Civil: Sexta série. São Paulo: Saraiva, 1997.

. "Le noveau Code de Procedure Civile vu par un juriste brésilien". Temas de direito processual Civil: Sexta série. São Paulo: Saraiva, 1997.

. "Reformas processuais e poderes do juiz". Temas de direito processual Civil: Oitava série. São Paulo: Saraiva, 2004.

. "Duelo e processo". Temas de direito processual Civil: Oitava série. São Paulo: Saraiva, 2004.

. "O neoprivatismo no processo civil". Temas de direito processual. Nona série. São Paulo: Saraiva, 2007.

. "As presunções e a prova". Temas de direito processual. Segunda série. São Paulo: Saraiva, 1980.

BARIONI, Rodrigo. "O procedimento da ação rescisória”. In: NERY JÚNIOR, Nelson, e WAMBIER, Teresa Arruda Alvim (coords.). Aspectos polêmicos e atuais dos recursos cíveis e de Outros Meios de Impugnação às Decisões Judiciais. Vol. 10. São Paulo: RT, 2007.

BARROSO, Luis Roberto. "Em algum lugar do passado: Segurança Jurídica, Direito Intertemporal e o Novo Código Civil”. In: ROCHA, Carmen Lúcia Antunes (Coord.). Constituição e Segurança Jurídica: Direito Adquirido, Ato Jurídico Perfeito e Coisa Julgada. $2^{\text {a }}$ ed. Belo Horizonte: Editora Fórum, 2005.

BAUR, Fritz. "Da importância da dicção iura novit curia". Revista de Processo, vol. 3, p. 169. São Paulo: RT, 1976.

BECCARIA, Cesare. Dos delitos e das penas. São Paulo: Martin Claret, 2002.

BEDAQUE, José Roberto dos Santos. Poderes instrutórios do juiz. São Paulo: RT, 1994. 
Direito e processo. Influência do Direito Material sobre o Processo. $3^{\mathrm{a}}$ ed. rev. e amp. São Paulo: Malheiros Editores, 2003.

. Tutela Cautelar e Tutela Antecipada. Tutelas Sumárias e de Urgência: Tentativa de Sistematização. $4^{\mathrm{a}}$ ed. rev. e ampl. São Paulo: Malheiros Editores, 2006.

Efetividade do processo e técnica processual. São Paulo: Malheiros Editores, 2006.

. "Nulidade processual e efetividade do processo". Revista de Processo 60. São Paulo: RT, outubro-dezembro/1990.

. "Os elementos objetivos da demanda examinados à luz do contraditório". In: CRUZ E TUCCI, José Rogério (coord.). Causa de Pedir e Pedido no Processo Civil (Questões Polêmicas). São Paulo: RT, 2002.

. "Cognição e decisões do juiz no processo executivo". In: FUX, Luiz, NERY JR, Nelson e WAMBIER, Teresa Arruda Alvim (coord.). Processo e Constituição. Estudos em homenagem ao Professor José Carlos Barbosa Moreira. São Paulo: RT, 2006.

BEDAQUE, José Roberto dos Santos; BRASIL JR., Samuel Meira; OLIVEIRA, Bruno Silveira de. "A oralidade no processo civil Brasileiro". Processo Civil: novas tendências. In: JAYME, Fernando Gonzaga et al. (coord.). Belo Horizonte: Del Rey, 2008.

BELLAVITIS, Mario. L'indentificazione delle azione. Padova-Venezia, 1924

BERIZONCE, Roberto O. Estudios de nulidades procesales. Buenos Aires: Hamurabi, s/d. BERMUDES, Sergio. Comentários ao Código de Processo Civil. Vol. VII. $2^{\mathrm{a}}$ ed. São Paulo: RT, 1977.

A reforma do Código de Processo Civil. $2^{\mathrm{a}}$ ed. São Paulo: Saraiva, 1996.

BERNI, Duílio Landell de Moura. "O duplo grau de jurisdição como garantia constitucional". In: PORTO, Sérgio Gilberto (coord.). As garantias do cidadão no processo civil: relações entre constituição e processo. Porto Alegre: Livraria do Advogado, 2003.

BETTI, Emilio. Ragione e azione. Rivista di Diritto Processuale 1. Padova: CEDAM, 1932.

Diritto processuale civile italiano. Roma : Foro Italiano, 1936. 
BIVATI, Paolo. "I procedimenti civili semplificati e accelerati: il quadro europeo e i riflessi italiani”. Rivista Trimestrali di Diritto e Procedura Civile 3. Milano: Guiffrè Editore, 2002.

BOBBIO, Norberto. Teoria da norma jurídica. 2a ed. rev. Bauru, SP: Edipro, 2003. Teoria do ordenamento jurídico. 10ª ed. Brasília: Unb, 1999. O positivismo jurídico. Lições de filosofia do direito. São Paulo: Ícone, 1995.

BONDIOLI, Luis Guilherme Aidar. Reconvenção no processo civil. São Paulo: Saraiva, 2009

BONÍCIO, Marcelo. Capítulos de sentença e efeitos dos recursos. São Paulo: RCS Editora, 2006.

BOTELHO DE MESQUITA, José Inácio. Da ação civil. São Paulo: EGRT, 1973. - "As novas tendências do direito processual: uma contribuição para o seu reexame". Revista Forense. Vol. 98, n. ${ }^{\circ}$ 361, maio-junho/2002. . "A causa pretendi nas ações reinvindicatórias", Revista de direito processual civil. Ano III, v. 6. São Paulo: 1962.

BRASIL JR., Samuel Meira. Justiça, Direito e Processo. A Argumentação e o Direito Processual de Resultados Justos. São Paulo: Editora Atlas, 2007.

BUENO, Cássio Scarpinella. Curso sistematizado de direito processual civil. Vol. 1. São Paulo: Saraiva, 2007.

Curso sistematizado de direito processual civil. Vol. 3. $6^{\mathrm{a}}$ ed. rev. e atual. São Paulo: Saraiva, 2013.

Tutela antecipada. São Paulo: Saraiva, 2004.

BUONCRISTIANI, Dino. L'allegazione dei fatti nel processo civile: profili sistematici. Torino: G. Giappichelli, 2001

BULYGIN, Eugenio. "Objectivity of Law in the View of Legal Positivism". In: COMANDUCCI, P.; e GUASTINI, R. (eds.), Analisi e Diritto, 2004.

BUZAID, Alfredo. “Exposição de motivos” do Código de Processo Civil de 1973. Agravo de petição. São Paulo: Saraiva, 1956. 
Da ação renovatória: de contrato de locação de imóveis destinados a fins comerciais. São Paulo: Saraiva, 1958.

CAIS, Fernando Fontoura da Silva. Preclusão e a instrumentalidade do processo. Dissertação apresentada como requisito para obtenção do título de Mestre da Faculdade de Direito da Universidade de São Paulo: São Paulo, 2006.

- "Em torno do formalismo processual: a criação de requisitos para a prática de atos processuais pelos tribunais". Revista Dialética de Direito Processual 57. São Paulo: Oliveira Rocha, dezembro/2007.

CALAMANDREI. Pierro. "La certezza del diritto e la responsabilità della dottrina." Opere Giuridiche. Vol. I. Napoli: Morano Editore, 1965. . Instituciones de derecho procesal civil. Buenos Aires: El Foro, 1996.

CALMON DE PASSOS, José Joaquim. Esboço de uma Teoria das Nulidades Aplicada às Nulidades Processuais. $1^{\mathrm{a}}$ ed. $3^{\mathrm{a}}$ tir. Rio de Janeiro: Forense, 2005.

CANOVA, Augusto Cerino. "La domanda ed il suo contenuto". In Commentario del Codice di Procesura Civile. Torino: UTET, 1980.

CAPPELLETTI, Mauro. "Problemas de reforma do processo civil nas sociedades contemporâneas". O processo Civil Contemporâneo. Curitiba: Juruá Editora, 1994. O processo civil no direito comparado. Belo Horizonte: Editora Líder, 2001.

CAPPELLETTI, Mauro; e GARTH, Bryant. Acesso à justiça. Porto Alegre: Fabris Editor, 1988.

CARMONA, Carlos Alberto. “A crise do processo e os meios alternativos para a solução de controvérsias". Revista de Processo 56. São Paulo: RT, outubro-dezembro/1989.

. "Reforma da constituição e processo: promessas e perspectivas". Revista Literária de Direito. Ano XI, número 56, fevereiro/março de 2005.

Arbitragem e processo. $2^{\mathrm{a}}$ ed. rev. e atual. São Paulo: Atlas, 2006.

. "Considerações sobre a evolução conceitual do processo". Revista de Processo 57. São Paulo: RT, janeiro-março/1990.

. “Em torno da petição inicial”. Revista de Processo 119. São Paulo: RT, 2005. 
CARMONA, Carlos Alberto (Org.). Reflexões sobre a reforma do Código de Processo Civil. São Paulo: Atlas, 2007.

CARNEIRO, Athos Gusmão. "A causa de pedir nas ações de investigação de paternidade”, Revista de Processo. Vol. 57. São Paulo: RT, 1994.

CARNELUTTI. Francesco. Instituciones del nuevo Proceso Civil Italiano. Barcelona: Casa Editorial Bosch, 1942.

. "In valore della sanzione del diritto". Rivista di Diritto Processuale 1. Padova: CEDAM, 1955.

. “La crise della legge”. Discorsi Intorno al Diritto. Padova: Cedam, 1937.

. Teoria geral do direito. Trad. de A. Rodrigues Queiró e Artur Anselmo de Castro. Rio de Janeiro: Âmbito Cultural, 2006.

CARVAlHO, Milton Paulo de (Org.). Direito Processual Civil. São Paulo: Quartier Latin, 2007.

O pedido no processo civil. Porto Alegre: Fabris, 1992.

CARVAlHO, Paulo de Barros. Curso de Direito Tributário. $15^{\mathrm{a}}$ ed. rev. e atual. São Paulo: Saraiva, 2003.

. “A endonorma e a perinorma da doutrina egológica de Carlos Cossio". In: Teoria da norma tributária. 4. ed. São Paulo: Max Limonad, 2002.

CAVALIERI FILHO, Sérgio. Programa de Responsabilidade Civil. $7^{\mathrm{a}}$ ed. rev. e amp. São Paulo: Atlas, 2007.

CAZZETA JR., José Jesus. "Conteúdo da causa de pedir e proposta de aplicação dessa categoria ao recurso extraordinário: um exame crítico". In Causa de pedir e pedido no processo civil. São Paulo: RT, 2002.

CHEIM JORGE, Flávio. Teoria Geral dos Recursos Cíveis. 4ª ed. Rio de Janeiro: Forense, 2009.

CHIOVENDA, Giuseppe. "Le forme nella difesa giudiziale del diritto". Saggi di diritto processuale civile (1900-1930). vol. I. Roma: Società Editrice Foro Italiano, 1930.

. "Identificazione delle azione. Sulla regola «ne eat iudex ultra petita partium»".

Saggi di diritto processuale civile (1900-1930). vol. I. Roma: Società Editrice Foro Italiano, 1930. 
. "Sulla eccezione". Saggi di diritto processuale civile (1900-1930). vol. I. Roma: Società Editrice Foro Italiano, 1930.

Instituições de direito processual Civil. São Paulo. Saraiva e Cia., 1942.

COMOGLIO, Luigi Paolo. "Contraddittorio". Digesto delle discipline privatistiche (sezione civile). Vol. IV, 4. ed. Torino: UTET, 1989.

. “Garanzie constituzionali e 'giusto processo' (modelli a confronto)”. Revista de Processo 90. São Paulo: RT, abril-junho/1998.

. Il principio di economia processuale. Vols. I e II. Padova: CEDAM, 1980 e 1982.

. "Il 'giusto processo' civile nella dimensione comparatistica". Revista de Processo 108. São Paulo: RT, junho-agosto/2002.

. "Giurisdizione e processo nel quadro delle garanzie constituzionale". Rivista Trimestrale di Diritto e Procedura Civile 4. Milano: Giuffrè Editore, 1994.

- "Note riopilogative su azione e forme di tutela, nell'ottica della domanda giudiziale”. Rivista di Diritto Processuale 2. Padova: CEDAM, 1993.

COMOGLIO, Luigi Paolo, FERRI, Corrado, e TARUFFO, Michele. Lezione sul processo civile. vols. I e II. Bologna: Il Moulino, 2006.

CONRADO, Paulo Cesar. Introdução à teoria geral do processo civil. $2^{\mathrm{a}}$ ed. rev. atual. e amp. São Paulo: Max Limonad, 2003.

CONSOLO, Claudio. "Oggetto del giudicato e principio dispositivo". Rivista Trimestrale di Diritto e Procedura Civile. Milano: Giuffrè Editore, 1991.

COSTA, Sergio. "Domanda giudiziale". Nuovo digesto italiano. Vol. 6. Torino: UTET, 1957.

COSTA E SILVA, Paula. Acto e processo: o dogma da irrelevância da vontade na interpretação e nos vícios do acto postulativo. Coimbra: Coimbra Editora, 2003.

COUTURE, Eduardo J. Fundamentos del derecho procesal civil. $4^{\mathrm{a}}$ ed. reimp. Buenos Aires: Editorial B de F, 2005.

Estudios de derecho procesal civil. Tomo I, II e III. $3^{\text {a }}$ ed. reimp. Buenos Aires: Depalma Ediciones, 1998. 
Introdución al estúdio del processo civil. Buenos Aires: Depalma, 1993.

CORAPI, Diego. "Iura novit cúria dell arbitrato Internazionale". Revista de arbotragem e mediação. Vo. 30. Julho de 2011, p. 183.

COSSIO, Carlos. La plenitud del ordenamiento jurídico. $2^{\mathrm{a}}$ ed. Buenos Aires: Editorial Los Andes, 2005.

CROZE, Hervé; MOREL, Christian. Procédure civile. Paris: Presses Universitaire de France, 1988.

CRUZ E TUCCI, José Rogério. A causa pretendi no processo civil. $2^{\mathrm{a}}$ ed. São Paulo: RT, 2001.

Lineamentos da Nova Reforma do CPC. $2^{\mathrm{a}}$ ed. São Paulo: RT, 2002.

Precedente como fonte do direito. São Paulo: RT, 2004.

. Ação Monitória. $3^{\mathrm{a}}$ ed. São Paulo: RT, 2001.

. Tempo e Processo. São Paulo: RT, 1997.

. "Causa pretendi no novo CPC português". In Causa de pedir e pedido no processo civil. São Paulo: RT, 2002.

DE SANTIS, Francesco. "Riforme processuali e $<<$ disponibilità $>>$ del regime preclusivo". Rivista Trimestrale di Diritto e Procedura Civile 4. Milano: Giuffrè Editore, 2004.

DEGENSZAJN, Daniel Raichelis. Alteração dos fatos no curso do processo e os limites da modificação da causa pretendi. Dissertação de mestrado. São Paulo: USP, 2010.

DEL VECCHIO, Giorgio. La crisi della scienza del diritto. Modena: Società Tipogratica Modenense, 1933.

DIDIER JR., Fredie. "Sobre a fundamentação da decisão judicial”. In: CARVALHO, Milton Paulo de (Org.). Direito Processual Civil. São Paulo: Quartier Latin, 2007.

Pressupostos processuais e condições da ação. O juízo de admissibilidade do processo. $3^{\text {a }}$ tiragem. São Paulo: Saraiva, 2010.

- "Sobre dois importantes, e esquecidos, princípios do processo: adequação e adaptabilidade do procedimento". Revista de Direito Processual Civil 21. Curitiba: Gênesis, julho-setembro/2001. 
Curso de Direito Processual Civil. Teoria Geral do Processo e Processo de Conhecimento. Vol. I. 11 a ed. Salvador: JusPodivm, 2009.

. "A tutela antecipatória dos artigos 273 e 461, CPC, como hipótese de suspensão do crédito tributário". Revista de Estudos Tributários, Porto Alegre, v. 19, p. 5 - 27, maio/jun., 2001.

DINAMARCO, Cândido Rangel. Fundamentos do processo civil moderno. Tomo I. $3^{\mathrm{a}}$ ed. rev. e atual. São Paulo: Malheiros Editores, 2000.

Instituições de direito processual civil. vol. I. $2^{\mathrm{a}}$ ed. São Paulo: Malheiros, 2002; vols. II e III. $3^{\text {a }}$ ed. São Paulo: Malheiros Editores, 2003.

. Nova era do processo civil. $1^{\text {a }}$ ed. São Paulo: Malheiros Editores, 2004.

. A instrumentalidade do processo. 12a ed. São Paulo: Malheiros Editores, 2006. . Execução Civil. $8^{\mathrm{a}}$ ed. São Paulo: Malheiros Editores, 2002.

. "Nasce um novo processo civill”. In: TEIXEIRA, Sálvio de Figueiredo (coord.).

Reforma do Código de Processo Civil. São Paulo: Saraiva, 1996.

. Vocabulário do processo civil. São Paulo: Malheiros, 2009.

. A reforma do código de processo civil. $2^{\mathrm{a}}$ ed. São Paulo: Malheiros, 1995.

. A reforma da reforma. São Paulo: Malheiros, 2002.

DINIZ, Maria Helena, Curso de Direito Civil Brasileiro: teoria geral das obrigações. Vol. II. 18. ed. São Paulo: Saraiva, 2003.

DIVITIIS, Paolo de. "Sulla teoria del meistbegüstigung nel processo civile tedesco. Forma e sostanza di provvedimento del giuduce". Rivista di Diritto Processuale 2, AprileGiugno/1993.

ELIAS, Carlos Eduardo Stefen, "As reformas processuais e o princípio da congruência entre sentença e pedido”. In Revista de Processo. Vol. 158. São Paulo: RT, 2008.

ENDERLE, Guilhermo Jorge. La congruencia procesal. Rubinzal-Culzoni SCC, 2007.

FARIAS, Cristiano Chaves de Farias; e ROSENVALD, Nelson. Direito civil. Teoria geral. $7^{\mathrm{a}}$ ed. Rio de Janeiro: Lumen Juris, 2009. p. 398.

FAZZALARI, Elio. Note in tema di diritto e processo. Milano: Giuffrè, 1957. 
. "Il giusto processo e i procedimenti speciali civili". Rivista Trimestrale di Diritto e Procedura Civile 1. Milano: Giuffrè Editore, março/2003. Istituzioni di diritto processuale. Padova: CEDAM, 1986.

FERRAZ, Sérgio (coord.). A norma jurídica. Rio de Janeiro: Freitas Bastos, 1980.

FERREIRA NETO, Osly da Silva. Ações tributárias coletivas. Porto Alegre: Sergio Antonio Fabris Editor, 2013.

FERRI, Corrado. Struttura del processo e modificazione della domanda. Padova: Cedam, 1975. Profili dell'accertamento constitutivo. Padova: CEDAM, 1970.

FERRONE, Ugo. Processo civile moderno. Imprenta Santa Maria Capua Vetere: Francesco Cavotta, 1912

FISS, Owen. Um novo processo civil. Estudos norte-americanos sobre jurisdição, constituição e sociedade. São Paulo: RT, 2004.

FONSECA, João Francisco Naves da. "A interpretação da sentença civil”. Revista Dialética de Direito Processual 62, São Paulo, maio 2008. Exame dos Fatos nos Recursos Extraordinário e Especial. São Paulo: Saraiva, 2011.

FORNACIARI JR., Clito. "Nova execução: aonde vamos?” Tribuna do direito 9. n. 114, outubro de 2004.

Da reconvenção no direito processual civil brasileiro. $2^{\mathrm{a}}$ ed. São Paulo: Saraiva, 1983.

Reconhecimento jurídico do pedido. São Paulo: RT, 1977.

FRANCHI, Giuseppe. La litispendenza. Padova: CEDAM, 1963.

FUX, Luiz, NERY JR, Nelson e WAMBIER, Teresa Arruda Alvim (coord.). Processo e Constituição. Estudos em homenagem ao Professor José Carlos Barbosa Moreira. São Paulo: RT, 2006.

GABBAY, Daniela Monteiro. Pedido e causa de pedir. São Paulo: Saraiva, 2010.

GAJARDONI, Fernando da Fonseca. Técnicas de aceleração do processo. São Paulo: Lemos \& Cruz, 2003. 
Flexibilidade procedimental. Um novo enfoque para o estudo do procedimento em matéria processual. Tese de doutorado. São Paulo: USP, 2007.

GARROTE, Angel Fermín. "Los actos jurídicos procesales". In: BERIZONCE, Roberto O., e outros. Estudios de nulidades procesales. Buenos Aires: Hamurabi, s/d.

GIANNOZZI, Giancarlo. La modificazione della domanda nel processo civile. Milano: A. Giuffrè, 1958.

GOLDSCHMIDT, James. Derecho procesal civil. Barcelona: Editorial Labor S.A., 1936. . Princípios gerais do processo civil. Belo Horizonte: Editora Líder, 2003. Teoría general del processo. Buenos Aires: EJEA, 1961.

GOMES, Orlando. Obrigações. 15ª ed. rev. e atual. Rio de Janeiro: Forense, 2001.

GOMES DA CRUZ, José Raimundo. "Causa de pedir e intervenção de terceiros". Revista dos Tribunais. Vol. 662. N. 47. Dez. 2002. P. 47 e ss.

GONÇALVES, Willian Couto. Intervenção de terceiros. Belo Horizonte: Del Rey, 1996.

GOUVEIA, Maria França. A causa de pedir na acção declarativa, Coimbra, Almedina, 2004.

GUIMARÃES SIQUEIRA, Cleanto. A defesa no processo civil. As exceções substanciais no processo de conhecimento. $3^{\mathrm{a}}$ ed. São Paulo: Saraiva, 2008.

GRAU, Eros Roberto. Ensaio e discurso sobre a interpretação/aplicação do direito. $2^{\mathrm{a}}$ ed. São Paulo: Malheiros, 2003.

GRASSO, Edoardo. "La regola della corrispondenza tra il chiesto e il pronunziato e la nullità da ultra o exrapetizione”. Rivista di Diritto Processuale. Padova: CEDAM, 1965.

GRINOVER, Ada Pellegrini. O processo em evolução. Rio de Janeiro: Forense Universitária, 1996.

Os princípios constitucionais e o código de processo civil. São Paulo: Bushatsky, 1975

. "Deformalização do processo e deformalização das controvérsias". Novas tendências do direito processual. $2^{\mathrm{a}}$ ed. Rio de Janeiro: Forense Universitária, 1991.

GRINOVER, Ada Pellegrini; CINTRA, Antonio Carlos Araujo; DINAMARCO, Candido Rangel. Teoria Geral do Processo. 17 ${ }^{\mathrm{a}}$ ed. São Paulo: Malheiros, 2001. 
GUASP, Jaime. Derecho procesal civil. Madrid: Graficas Gonzalez, 1961.

HABSCHEID, Walter J. “As bases do direito processual civil”. Revista de Processo 11-12. São Paulo: RT, 1978.

HEINITZ, Ernesto. I limiti oggettivi della cosa giudicata. Padova, Cedam, 1937.

HERRERO, Luis René. “El derecho a ser oído. Eficacia del debate procesal”. In: ARAZI, Roland (et. al). Debido proceso. Realidad y debido proceso. El debido proceso y la prueba. $1^{\text {a }}$ ed, Santa Fe: Rubizinal-Culzoni, 2003.

IGLESIAS, André de Freitas. Da sentença que reconhece a existência de obrigação como título executivo (CPC, art. 475-N, I). Dissertação de mestrado apresentada como requisito para obtenção do título de mestre. São Paulo: PUC/SP, 2007.

JAUERNIG, Othmar. Direito processual civil. Trad. F. Silveira Ramos. Coimbra: Almedina, 2002.

JOLOWICZ, J.A. "Comparative law and the reform of civil procedure". Legal Studies. Vol. 8. n. 1. March/1988.

JORGE, Mário Helton. "O Regime Jurídico da Fungibilidade das Demandas e dos Provimentos no Código de Processo Civil: relativização dos dogmas da inércia da jurisdição, da correlação entre pedido e decisão, da vinculação aos fatos da causa e da imutabilidade da coisa julgada". Revista de Processo 122. São Paulo: RT, 2005.

KAPLAN, Lewis A. “Implied causes of action”, 8 Litigation 33 1981-1982.

KELSEN, Hans. Teoria pura do direito. São Paulo: Martins Fontes, 1999.

KLIPPEL, Rodrigo. Ação Rescisória. Teoria e Prática. Niterói: Impetus, 2008.

As Condições da Ação e o Mérito à Luz da Teoria da Asserção. São Paulo: Scortecci, 2005.

KOMATSU, Roque. Da invalidade no processo civil. São Paulo: RT, 1991.

LACERDA, Galeno. “O Código e o Formalismo Processual”. Ajuris 28. Porto Alegre: Ajuris, julho/1993.

. Despacho Saneador. $3^{\text {a }}$ ed. Porto Alegre: Sergio Antonio Fabris Editor, 1990.

. "Processo e Cultura". Revista de Direito Processual Civil. $3^{\circ}$ Vol. São Paulo:

Saraiva, 1962. 
LARENZ, Karl. Metodologia da Ciência do Direito. $4^{\mathrm{a}}$ ed. Lisboa: Fundação Calouste Gulbenkian, 2005.

LEONEL, Ricardo Barros. “A eficácia imediata da sentença e as reformas do código de processo Civil: um aspecto da caminhada pela efetividade da tutela jurisdicional". Revista de Processo 120. São Paulo: RT, 2005.

. Causa de pedir e pedido: o direito superveniente. São Paulo: Método, 2006.

LENT, Friedrich. Diritto Processuale Civile Tedesco. Trad. Edoardo F. Ricci Napoli: Morano Editore, 1962.

LIEBMAN. Enrico Tullio. Manuale di diritto processuale civile. Principi. $5^{\mathrm{a}}$ ed. Milano: Giufrè, 1992.

. Manual de direito processual civil. vol. I. $3^{\mathrm{a}}$ ed. São Paulo: Malheiros, 2006.

. Eficacia y autoridad de la sentencia y otros estudios sobre la cosa jugada.

Buenos Aires: Ediar Editores, 1946.

. "Fondamento del principio dispositivo". Problemi del proceso civile. Milano:

Morano, 1962.

LUGO, Andrea. Manuale di diritto processuale civile. Milano: A. Giuffrè, 1986.

MANDRIOLI, Crisanto. Corso di diritto processuale civile. Vols. I, II e III, $18^{\mathrm{a}}$ ed. Torino: Giappicheli Editore, 2006.

- "Riflessioni in tema di 'petitum' e di 'causa petendi”. Rivista di Diritto Processuale 3. Padova: CEDAM, 1984.

MARCATO, Antônio Carlos. Procedimentos especiais. 13ª ed. São Paulo: Atlas, 2008.

MARINONI, Luiz Guilherme. Técnica processual e tutela dos direitos. São Paulo: RT, 2004.

Tutela inibitória. Individual e coletiva. $4^{\mathrm{a}}$ ed. rev. atual. e amp. São Paulo: RT, 2006

Tutela específica: arts. 461, CPC e 84, CDC. $2^{\mathrm{a}}$ ed. rev. São Paulo: RT, 2001.

MARQUES, Frederico. Instituições de Direito Processual Civil. Vols. I, II, III e IV. Rio de Janeiro: Forense, 1958. 
MARTINS, Ives Gandra da Silva; e MENDES, Gilmar Ferreira. Controle concentrado de constitucionalidade. $2^{\text {a }}$ ed. São Paulo: Saraiva, 2005.

MAXIMILIANO, Carlos. Hermenêutica e aplicação do direito. Rio de Janeiro: Freitas Bastos, 1965.

MEDINA, José Miguel Garcia et al (coord.). Os poderes do juiz e o controle das decisões judiciais. Estudos em homenagem à Professora Teresa Arruda Alvim Wambier. $2^{\text {a }}$ tir. São Paulo: RT, 2008.

MITIDIERO, Daniel. “A pretensão de condenação”. Revista de Processo 129. São Paulo: RT, novembro de 2005.

MOLLICA, Rogerio. "O excesso de formalismo como obstáculo à celeridade processual”. Bases científicas para um renovado Direito Processual. vol. 1. São Paulo: IBDP, 2008.

MORAES, José Rubens de. "Princípio da oralidade: visão comparativa das suas múltiplas manifestações nos sistemas common law e 'europeu continental' - breve confronto com as modernas tendências do processo civil brasileiro em tempos de reforma". In: CARVAlHO, Milton Paulo de (Org.). Direito Processual Civil. São Paulo: Quartier Latin, 2007.

MORELLO, Augusto. Avances Procesales. Buenos Aires: Rubizinal - Culzoni Editores, 2003.

MOUSSALLEM, Tárek Moysés. Revogação em matéria tributária. São Paulo: Noeses, 2005.

Fontes do direito tributário. $2^{\mathrm{a}}$ ed. São Paulo; Noeses, 2006.

WAMBIER, Teresa Arruda Alvim (coord.). Processo e Constituição. Estudos em homenagem ao Professor José Carlos Barbosa Moreira. São Paulo: RT, 2006.

NEVES, Celso. Contribuição ao estudo da coisa julgada civil. Dissertação de Concurso à Cátedra de Direito Judiciário Civil da Faculdade de Direito da Universidade de São Paulo. São Paulo, 1970.

NERY JR, Nelson. "Mudança na causa de pedir”, Soluções práticas vol. 4. São Paulo: RT, 2012. p 599. "Litispendência”, Soluções práticas vol. 4. São Paulo: RT, 2012. p. 261. 
OLIVEIRA, Bruno Silveira de. O juízo de identificação de demandas e de recursos no processo civil. São Paulo: Saraiva, 2011.

- “Os princípios constitucionais, a instrumentalidade do processo e a técnica processual”. Revista de Processo 146. São Paulo: RT, 2007.

. “Um novo conceito de sentença?" Revista de Processo 149. São Paulo: RT, 2007.

. Conexidade e efetividade processual. São Paulo: RT, 2007.

. "O formalismo do sistema recursal à luz da instrumentalidade do processo". Revista de Processo 160. São Paulo: RT, 2008.

ORTEIZA, Eduardo. "El debido processo. (Evolución de la garantía y autismo procesal)". In: ARAZI, Roland (et. al). Debido proceso. Realidad y debido proceso. El debido proceso y la prueba. $1^{\text {a }}$ ed. Santa Fe: Rubizinal-Culzoni, 2003.

PARENTE, Eduardo de Albuquerque. Jurisprudência: da Divergência à Uniformização. São Paulo: Atlas, 2006.

PICÓ I JUNOY, Joan. La modificación de la demanda en el proceso civil. Valencia: Tirant lo Blanch, 2006.

PISANI, Andrea Proto. Lezoni di diritto processuale civile. $5^{\text {a }}$ ed. Napoli: Jovene Editore, 2006.

PODETTI, J. Ramiro. Teoría y técnica del proceso civil y trilogía estructural de la ciencia del proceso civil. Buenos Aires: Ediar, 1963.

POLI, Roberto. "Sulla sanabilità della inosservanza di forme prescritte a pena di preclusione e decadenza". Rivista di Diritto Processuale 2. Padova: Cedam, 1996.

PONTES DE MIRANDA. Comentários ao Código de Processo Civil. Tomo III e IV. Rio de Janeiro: Forense, 1974.

Comentários ao Código de Processo Civil. Tomo II. Rio de Janeiro: Forense, 1941.

PUGLIESE, Giovanni. "Domanda giuduziale (diritto romano)". Enciclopedia del diritto. Vol. 13. Milano: Giuffrè, 1964.

. "Giudicato civile (diritto vigente)". Enciclopedia del diritto. Vol. 18. Milano:

Giuffrè, 1969. 
PUOLI, José Carlos. Os poderes do juiz e a reforma do Código de Processo Civil. São Paulo: Juarez de Oliveira, 2002.

RAGONE, Álvaro J. D. Pérez. "Profili della Giustizia Processuale (Procedural Fairness): La Giustificazione Etica del Processo Civile”. Rivista di Diritto Processuale 4. Padova: CEDAM, julho-agosto/2008.

RAGONE, Álvaro J. D. Pérez; e PRADILLO, Juan Carlos Ortiz. Código Procesal Civil alemán (ZPO). Traducción con un estudio introductorio al proceso civil alemán contemporáneo. Montevideo: Konrad-Adenauer-Stiftung, 2006.

REALE, Miguel. Teoria do direito e do estado. $3^{\text {a }}$ ed. rev. São Paulo: Martins, 1970. Filosofia do direito. $18^{\mathrm{a}}$ ed. São Paulo: Saraiva, 1998.

RICCI, Edoardo F. "Princípio do contraditório e questões que o juiz pode propor de ofício”. In: FUX, Luiz, NERY JR, Nelson e WAMBIER, Teresa Arruda Alvim (coord.). Processo e Constituição. Estudos em homenagem ao Professor José Carlos Barbosa Moreira. São Paulo: RT, 2006.

RICCI, Gian Franco. "Il processo civile fra ideologie e quotidianità". Rivista Trimestrali di Diritto e Procedura Civile 59. Milano: Guiffrè Editore, 2005.

. "L'allegazione dei fatti nel nuovo processo civile". Rivista Trimestrale di Diritto e Procedura Civile 3. Milano: Guiffrè Editore, 1992.

"Individuazione o sostanziazione nella riforma del processo civile", Rivista Trimestrale di diritto e procedura civile 4. Milano: Guiffrè Editore, 1995.

ROBLES, Gregorio. O direito como texto. Quatro estudos de teoria comunicacional do direito. Barueri - SP: Manole, 2005.

ROCCO, Alfredo. La interpretación de las leyes procesales. Buenos Aires: Valetta Ediciones, 2005.

ROCHA, Carmen Lúcia Antunes (Coord.). Constituição e Segurança Jurídica: Direito Adquirido, Ato Jurídico Perfeito e Coisa Julgada. $2^{\text {a }}$ ed. Belo Horizonte: Editora Fórum, 2005.

RODRIGUES, Silvio. Direito Civil. Parte Geral. 32a ed. rev. e atual. São Paulo: Saraiva, 2002. 
ROSENBERG, Leo. Tratado de derecho procesal civil. Tomo I. Buenos Aires: Ediciones Juridicas Europa-America, 1955.

ROSS, Alf. Tû-Tû. Trad. de Edson L. M. Bini. São Paulo: Quartier Latin, 2004.

RUBIN, Fernando. A preclusão na dinâmica do processo civil. Porto Alegre, Livr. do Advogado, 2010.

SALLES, Carlos Alberto de. Execução Judicial em Matéria Ambiental. São Paulo: RT, 1999.

- Processo Civil e Interesse Público: o processo como instrumento de defesa social. $1^{\text {a }}$ ed. São Paulo: RT, 2003.

SAMPAIO, Tércio. "Teoria da norma jurídica: um modelo pragmático". In: FERRAZ, Sérgio (coord.). A norma jurídica. Rio de Janeiro: Freitas Bastos, 1980. p. 7 e ss.

SANCHES, Sydney. "Objeto litigioso do processo e objeto litigioso do processo". Revista de Processo 13. São Paulo: RT, 1979.

SANTOS, Andrés de la Oliva. Objeto del processo y cosa juzgada en el processo civil. Cizur Menor (Navarra): Editorial Aranzadi, 2005.

SANTOS, Moacyr Amaral. Direito processual civil. vol. 3. São Paulo: Max Limonad, 1967.

. Primeiras linhas de direito processual civil. Vol. 3. 16 a ed. São Paulo: Saraiva, 1997.

SATTA, Salvatore. Direito processual civil. $7^{\mathrm{a}}$ ed. vol. I e II. Trad. Paulo Autuori. São Paulo, Borsoi, 1973.

" "Domanda giudiziale (diritto processuale civile)". Enciclopedia del diritto. Vol.

1. Milano: Giuffrè, 1964.

SATTA, Salvatore; PUNZI, Carmine. Diritto processuale civile. 13. ed. Padova:

Cedam, 2000.

SAVIGNY, M. F. C. Sistema del derecho romano actual. Tomo I. Traduzido do alemão por M. Ch. Guenoux. Madrid: Gongora Ed. e Cia, 1878.

SCHWAB, Karl Heinz. El objeto litigioso en el proceso civil. Trad. Tomas A Banzhaf. Buenos Aires : EJEA, 1968. 
SCHÖNKE, Adolfo. Derecho Procesal Civil. Barcelona: BOSCH, s/a.

SEARLE, John R. Expressão e significado. Estudos das teorias dos atos de fala. São Paulo: Martins Fontes, 2002.

SICA, Heitor Vitor Mendonça. O direito de defesa no processo civil brasileiro. Um estudo sobre a posição do réu. São Paulo: Atlas, 2011.

Preclusão processual Civil. São Paulo: Atlas, 2006.

. "Algumas implicações do novo conceito de sentença no processo civil, de acordo com a lei $n^{\circ}$. 11.232/2005”. In: CARMONA, Carlos Alberto. (Org.). Reflexões sobre a reforma do Código de Processo Civil. São Paulo: Atlas, 2007.

. "Reflexões em torno da teoria geral dos procedimentos especiais". Revista de Processo 208. São Paulo: RT, 2012.

SILVA, Ovídio Araújo Baptista da. Sentença e coisa julgada. $4^{\mathrm{a}}$ ed. Rio de Janeiro: Forense, 2006.

. "Processo de Conhecimento e procedimentos especiais". In: Da sentença liminar à nulidade da sentença. Rio de Janeiro: Forense, 2002.

SILVA, Virgílio Afonso da. “A evolução dos direitos fundamentais". Revista LatinoAmericana de Estudos Constitucionais $n^{\circ}$ 6. Belo Horizonte: Del Rey, julho-dezembro de 2005.

SOBRINHO, Elcio de Cresci. Objeto litigioso no processo civil. Porto Alegre: Fabris, 2008.

. "De Lent a Habscheid e Jauernig". Revista brasileira de direito processual 19. Rio de Janeiro: Forense, 1979.

SOUSA, Miguel Teixeira de. "Sobre o sentido e a função dos pressupostos processuais (algumas reflexões sobre o dogma da apreciação prévia dos pressupostos processuais na ação declarativa)". Revista de Processo 63. São Paulo: RT, julho-setembro/1991. . "Aspectos do novo processo civil português". Revista de Processo 86. São Paulo: RT, abril-junho/1997. O Concurso de Títulos de Aquisição da Prestação. Coimbra: Almedina, 1988. 
SOUZA, Carlos Aurélio Mota de. Segurança jurídica e jurisprudência. São Paulo: LTr, 1996.

TALAMINI, Eduardo. Tutela relativa aos deveres de fazer e de não fazer e sua extensão aos deveres de entrega de coisa (CPC, arts. 461 e 461-A; CDC, art. 84). $2^{\mathrm{a}}$ ed. rev. atual. e amp. São Paulo: RT, 2003.

. Coisa julgada e sua revisão. São Paulo: RT, 2005.

TARDIN, Luiz Gustavo. Fungibilidade das tutelas de urgência. São Paulo: RT, 2006.

TARUFFO, Michele. La motivazione della sentenza civile. Pádua: Cedam, 1975.

. "Senso comune, esperienza e scienza nel ragionamento del giudice". Revista Trimestrale di Diritto e Procedura Civile 3. Milano: Giuffrè Editore, 2001.

TARZIA, Giuseppe. Profili della sentenza civile impugnabile. Milano: Giuffrè Editore, 1967.

.La istruzioni del giudice alle parti nel processo civile". Rivista di Diritto Processuale 4. Padova: CEDAM, outubro-dezembro/1981.

TAVARES, André Ramos. Curso de Direito Constitucional. São Paulo: Saraiva, 2002.

TEIXEIRA, Guilherme Freire de Barros. O princípio da Eventualidade no Processo Civil. São Paulo: RT, 2004.

THEODORO JÚNIOR, Humberto. "Tutela diferenciada: opção do credor entre a ação executiva e a ação ordinária de cobrança". Revista Dialética de Direito Processual 4. São Paulo: Oliveira Rocha, julho/2003.

. “A preclusão no processo civil”. Revista dos Tribunais 784. São Paulo: RT, fevereiro/2001.

. Curso de direito processual civil. Vol. I. $32^{\mathrm{a}}$ ed. rev. e atual. Rio de Janeiro: Forense, 2000.

THEOTONIO NEGRÃO. Código de Processo Civil e legislação processual em vigor. $43^{\mathrm{a}}$ ed. São Paulo: Saraiva, 2011.

VENOSA, Sílvio de Salvo. Direito Civil. Parte Geral. Vol.1. 3 ed. São Paulo: Atlas. 2003. VESCOVI. "La modificacion de la demanda", Revista de Processo 30. São Paulo: RT, 1983. 
VIANA, Juvencio Vasconselos. "Causa de pedir no processo de execução". In Causa de pedir e pedido no processo civil. São Paulo: RT, 2002.

VICENT, Jean; e GUINCHARD, Serge. Procédure Civile. 25e ed. Paris: Dalloz, 1999.

VIEIRA, Luis Alberto. "Teoria general del acto juridico y los pressupuestos procesales". Estudios Jurídicos en Memoria de Eduardo J. Couture. Montevideo: Facultad de Derecho, 1957.

VIGLIAR, José Marcelo Menezes. "Pedido Genérico e projeto de sentença". In Causa de pedir e pedido no processo civil. São Paulo: RT, 2002.

VILANOVA, Lourival. Estruturas lógicas e o sistema de direito positivo. $3^{\mathrm{a}}$ ed. São Paulo: Noeses, 2005.

WAMBIER, Luiz Rodrigues. Sentença Civil: liquidação e cumprimento. $3^{\mathrm{a}}$ ed. rev. atual. e amp. São Paulo: RT, 2006.

WAMBIER, Luiz Rodrigues; WAMBIER, Teresa Arruda Alvim; e MEDINA, José Miguel Garcia. Breves comentários à nova sistemática processual civil 2. São Paulo: RT, 2006.

WAMBIER, Teresa Arruda Alvim. "Anotações sobre o princípio do contraditório como um dos fundamentos do processo civil contemporâneo". In: CARVALHO, Milton Paulo de (Org.). Direito Processual Civil. São Paulo: Quartier Latin, 2007.

WATANABE, Kazuo. Cognição no processo civil. $2^{\mathrm{a}}$ ed. atual. São Paulo: Bookseller, 2000.

. “Ações dúplices”. Revista de Processo 31. São Paulo: RT, 1983.

YARSHELL. Flávio Luiz. Tutela Jurisdicional Específica nas Obrigações de Prestar Declaração de Vontade. São Paulo: Malheiros, 1993.

Ação Rescisória: Juízos rescindente e rescisório. São Paulo: Malheiros Editores, 2005.

Tutela jurisdicional. $2^{\mathrm{a}}$ ed. rev. e atual. São Paulo: DPJ, 2006.

YARSHELL. Flávio Luiz, e MORAES, Maurício Zanoide de (orgs.). Estudo em homenagem à Professora Ada Pellegrini Grinover. São Paulo: DPJ Editora, 2005.

ZANZUCCHI, Marco Tullio. Diritto Processuale Civile. Milano: Giuffrè Editore, 1964. 
Nuove domande, nuove eccezioni e nuove prove in appello. Milano: Soc. editr. Librar., 1916. 


\section{RESUMO}

A tese cuida de identificar o que é uma demanda é qual é o conteúdo de uma demanda, estipulando critérios para sua interpretação, de modo a estabelecer a relação lógica de correlação entre demanda e tutela jurisdicional. A demanda representa a manifestação da parte, no sentido de que seja produzido $\left(1^{\circ}\right)$ um ato de poder do Estado, que deve ter aptidão para desencadear uma determinada transformação da realidade; e $\left(2^{\circ}\right)$ a própria transformação da realidade (bem da vida), com o cumprimento de uma prestação (tutela condenatória), pelo fornecimento de uma certeza quanto a uma relação jurídica (tutela declaratória) ou pela criação, extinção ou modificação de uma relação jurídica (tutela constitutiva). A tutela jurisdicional, por sua vez, deve representar a negativa ou o acatamento desta solução proposta. É concedida em favor do réu, quando a demanda é rejeitada (sentença terminativa) e quando o direito do réu é reconhecido pela Jurisdição (improcedência) ou é concedida em favor do autor, quando a demanda é acolhida, permitindo que os efeitos jurídicos pleiteados sejam produzidos. Via de regra, é exigida uma demanda para estabelecer os limites da atuação jurisdicional. O Estado não pode exercer sua função jurisdicional, salvo se devidamente provocado (inércia). Uma vez demandado, antes de emitir qualquer ato de poder, o juiz deve submeter a demanda à apreciação dos demais indivíduos que podem vir a ser afetados pelo processo (contraditório). Por força das exigências anteriormente citadas, o Estado acaba limitado pela solução proposta pelo demandante, não podendo ir além, aquém ou decidir o que não foi demandado (correlação). Desse modo, estudamos a correlação a partir de suas características essenciais e, depois, tratamos das exceções legais a essa correlação, existentes tradicionalmente nos chamados "pedidos implícitos" e nos procedimentos especiais. Além disso, cuidamos, sob esta mesma ótica, das hipóteses de "resultado prático equivalente", conversão da tutela específica em ressarcitória e da admissão de "fato novo" no processo civil. Ao fim, tratamos das possíveis consequências do desrespeito à congruência, à luz da regra da instrumentalidade das formas.

PALAVRAS-CHAVE: Processo civil brasileiro, demanda, tutela jurisdicional, congruência, tria eadem, objeto litigioso do processo, pedido, causa de pedir, partes. 


\section{ABSTRACT}

The aim of this thesis is to identify what is a pleading and what is the ideal content of a pleading, stipulating criteria for its interpretation, in order to establish the logical relationship between pleading and adjudication. Pleading is an act of will of the plaintiff, in the sense that (1) a verdict of the State is produced, capable of triggering a certain transformation of reality and (2) the actual transformation of reality, with the compliance of a provision, by furnishing certainty as to a legal relationship or the creation, modification or termination of a legal relationship. Adjudication, in turn, should represent the negative or the compliance of this proposed solution. It is granted in favor of the defendant, when the suit is rejected and the defendant's right is protected by Jurisdiction, and it is granted in favor of the plaintiff, when the pleading is received, allowing the proposed legal effects to be produced. As a rule, pleading is required to establish the limits of the judicial role. The State may not exercise its judicial function unless properly provoked (inertia), and before issuing verdict, must be submitted to the previous consideration of the other parties that may be affected by the civil suit. Pursuant to the requirements mentioned above, the State is limited by the solution proposed by the plaintiff, may not go beyond, behind or decide what has not been sued (correlation). Thus, one studied this relationship since its essential characteristics, and then treated the legal exceptions to this correlation in the traditionally called "implicit pleading" and special procedures. Also, took care, under this same perspective, of the rule of the "practical result equivalent", of the rule of conversion of specific protection in redressing and the rule of admission of the "new fact" in civil proceedings. At the end, one addressed the possible consequences of the disregard of congruence in the light of the instrumentality rule of the forms.

KEYWORDS: Brazilian civil procedure, pleading, claim, adjudication, matching, tria eadem, object of the litigation, cause of action, parties. 


\section{RIASSUNTO}

La tesi si occupa di identificare ciò che una domanda è e qual è il contenuto di una domanda, contenente i criteri per la sua interpretazione, al fine di stabilire la relazione logica di corrispondenza tra domanda e tutela giurisdizionale. Domanda è la manifestazione della parte, nel senso che è prodotto (1) d'un atto di potere (mezzo) dello Stato, qui deve avere la possibilità di innescare una certa trasformazione della realtà (fine), e (2) la trasformazione effettiva della realtà (bene giuridico), imponendo una prestazione (condanna), fornendo la certezza di un rapporto giuridico (dichiarazione) o la creazione, la modifica o la cessazione di un rapporto giuridico (costituzione). La tutela giurisdizionale, a sua volta, dovrebbe rappresentare la negativa o la conformità di questa soluzione proposta. Si è concessa a favore del convenuto, quando la domanda viene respinta (terminative) e il diritto del convenuto è protetto dalla Giurisdizione, e viene concessa a favore del autore, quando la domanda viene ricevuta, permettendo che si producono gli effetti giuridici supplicati. Come regola generale, una domanda è necessaria per stabilire i limiti della funzione giurisdizionale. Lo Stato non può esercitare la sua funzione giurisdizionale se non adeguatamente provocato da una domanda (inerzia), e una volta citato in giudizio prima di emettere un atto di potenza, devono presentare alla considerazione di altri soggetti che possono essere interessati (contraddittorio). In conformità ai requisiti di cui sopra, lo Stato è solo limitato dalla soluzione proposta nella demanda, non può andare al di là, dietro o decidere di non stato citato in giudizio (corrispondenza). Quindi, studiamo questo rapporto dalle sue caratteristiche essenziali, e quindi trattammo delle eccezioni legali a questa corrispondenza esistente tradizionalmente nelle chiamate "domande implicite" e procedimenti speciali. Inoltre, facciamo attenzione, in questa stessa prospettiva, alle possibilità di "risultato equivalente pratico" conversione di una protezione specifica in tutela generica e ammissione di nuovi fatti in sede civile. Alla fine, affrontammo le possibili conseguenze della mancata alla regola della corrispondenza alla luce della strumentalità delle forme.

PAROLE CHIAVE: Processo civile brasiliano, domanda, tutela giurisdizionale, corrispondenza, tria eadem, l'oggetto del processo, chiesto, azione legale, soggetti. 